Vol. 92, 2003

\title{
VASCULAR PLANTS IN THE BOLIMÓW LANDSCAPE PARK
}

\author{
ROŚLINY NACZYNIOWE \\ BOLIMOWSKIEGO PARKU KRAJOBRAZOWEGO
}

\section{JANINA JAKUBOWSKA-GABARA ${ }^{1}$, LESZEK KUCHARSKI ${ }^{2}$ AND AURELIA U. WARCHOLIŃSKA'}

\footnotetext{
${ }^{1}$ Chair of Geobotany and Plant Ecology, University of Łódź, Banacha 12/16, PL-90-237 Łódź, jjg@biol.uni.lodz.pl,urwar@biol.uni.lodz.pl

${ }^{2}$ Chair of Nature Conservation, University of Łódź, Banacha 1/3, PL-90-237 Łódź, kuchar@biol.uni.lodz.pl
}

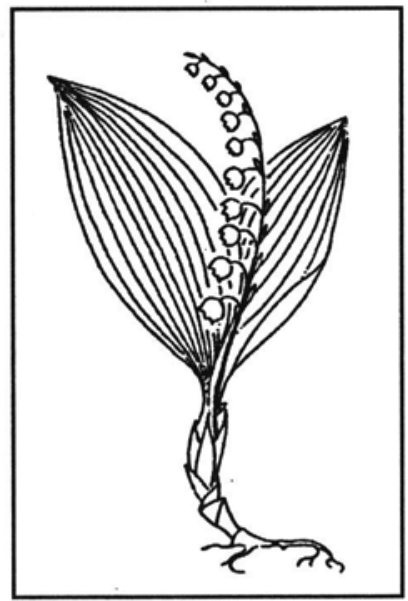




\begin{abstract}
Janina JAKUBOwSKA-GaBARA, Leszek KUCHARSKI and Aurelia U. WARChOlińSKA. Vascular plants in the Bolimów Landscape Park. Monogr. Bot., Vol. 92, 5-195, 2003.

In 1996-2001 the vascular plants of the Bolimów Landscape Park and its protection zone were cartographically studied. A cartogram method using a regular net of squares $1 \mathrm{~km}$ in knot to knot length was applied. Field data, data from published and unpublished studies and data from the Herbarium Universitatis Lodziensis (LOD) materials constituted the bases for developing maps displaying the distribution of 1049 vascular plant taxa recorded in the study area. A high diversity of habitats resulted in the richness and diversity of the flora in the investigated area. The highest floristic diversity and presence of interesting, rare and threatened species was displayed by the phytocoenoses of deciduous forests and humid meadows and bogs. In the investigated flora 51 legally protected species and 126 endangered and vulnerable ones in the scale of the region and of Poland were determined. The most interesting taxa are: Carex vaginata, Festuca amethystina subsp. ritschlii, Ostericum palustre, Succisella inflexa.
\end{abstract}

Key words: vascular plants; flora; atlas of distribution; the Bolimów Landscape Park; Central Poland. 


\section{INTRODUCTION}

Until the early $80 \mathrm{~s}$ of the $20^{\text {th }}$ century the Bolimów Old-Growth Forest, together with its surrounding agricultural areas, was an area little known from the floristic point of view. There are only two studies from the $19^{\text {th }}$ and the first half of the $20^{\text {th }}$ century in which data on the flora and vegetation of this part of the country are included (VOCKE 1857; GoLONKA 1927). It was as late as in the $60 \mathrm{~s}$ and $70 \mathrm{~s}$ of this century when more precise articles about the vegetation cover of the terrain (MowsZowICZ 1960, 1978; OLACZEK 1963, 1971, 1972, 1974; WIŚNIEWSKI 1965, 1974, 1976a, b; DZIADEK 1969; WOJCIECHOWSKA 1969; SOWA 1971; JAROSZ 1976; JAKUBOWSKAGABARA 1978) were published. However, the greatest interest in the vegetation cover of the Bolimów Old-Growth Forest was noted after 1979. In the last quarter of the $20^{\text {th }}$ century numerous studies devoted to the flora and vegetation of the area were made, both published (WARCHOLIŃSKA 1982, 1988-1990, 1997a, b; JAKUBOWSKA-GABARA, KUCHARSKI 1983; JAKUBOWSKA-GABARA 1985, 1987, 1988, 1990, 1992, 1994, 1996, 1999; JAKUBOWSKA-GABARA, Pisarek 1997; Olaczek, JaKubowska-Gabara, Pisarek 1988; Pisarek 1989; KurZac, KuCHARSKI 1990-1991; ZIELONY 1990; CZYŻEWSKA 1992; KUCHARSKI 1997; KUCHARSKI, PisareK 1998; PisAreK, KuCharSKi 1999; JAKUbOWSKA-Gabara, ZielińSKa 2001; JaKubOWSKa-Gabara, ŁUCZAK 2002) and unpublished (OlaczeK, KurZaC 1979a, b; BogUleWSKA 1980; JAKUBOWSKA-Gabara 1980; JAKUBOWSKA-GABARA, KUCHARSKI 1981; KNAPEK 1981; KUlisieWICZ 1981; PISAREK 1984; WIETESKa 1984; KURZAC et al. 1987; OlaCZEK, PisAREK 1987; KurZAC, PISAREK 1994; OlaCZeK, KuChaRSKi 1994-1995; TYSZKOWSKa A. 1994; TYSZKowSKa B. 1994; KuCHARSKI 1995; IrCHA 1996; WolaŃSKa 1996; MACIAK 1997; OWCZAREK 1997; WiŚNIEWSKA 1997; DuSZYŃSKA 1998; RuSZCZYŃSKA 1998; PAJąK 2001; Popow 2001; SELIGA 2002). Multiannal investigations have proved that the flora of this area is rich and interesting. The diversity and presence of numerous interesting plant species was one of important arguments for creating the Bolimów Landscape Park (BLP) in 1986. First of all, its borders encompass the extensive complex of the Bolimów Old-Growth Forest.

In the late $90 \mathrm{~s}$ of the $20^{\text {th }}$ century a collection of studies presenting the vegetation of BLP were published (CZYżewSKa 1999; JAKUBOWSKa-Gabara 1999; KuCHARSKI, PISAREK 1999; PISAREK, KUCHARSKI 1999; WARCHOLIŃSKA 1999). While the flora of the park was a subject of a separate investigation numerous short studies about the sites of more interesting vascular plant species noted in the area were then published. The present work reviews the current knowledge of the vascular flora of the Bolimów Landscape Park and present the distribution of plant species determined there.

Acknowledgements: We would like to thank Małgorzata ŁACIŃSKA, MSc. and Katarzyna ZIELIŃSKA, MSc., for preparation of the computer data base and graphical elaboration of cartograms. The authors also thank the Directorate of the Bolimów Landscape Park for giving access to working backgrounds of maps with imposed nets of squares and for kindness and help while carrying out field research. The topic was realized as part of the University of Łódź grants $(505 / 734,505 / 667,505 / 449,595 / 416)$

\section{STUDY AREA}

The Bolimów Landscape Park was created in 1986. It then covered an area of 17900 ha, which in 1995 was increased to 23130 ha. The protection zone that encircled the park was a 200 meter wide belt of adjoining terrain. In 1998 the zone was widened and it now covers an area of 
20470.5 ha. The park are mostly woods (14149.2 ha) and agricultural land and orchards (5620.6 ha). The area of meadows and bogs is $1928.5 \mathrm{ha}$, while that of bogs and open waters is $97.6 \mathrm{ha}$.

The park is located at the border of the Lódzkie and Mazowieckie (Mazovian) Voivodeships. The north-eastern part of the park comprises the Puszcza Mariańska civil parish, and partially the civil parishes of Wiskitki, Mszczonów and Radziejowice. In the Łódzkie Voivodeship the park is located in the civil parishes of Nieborów, Bolimów, Skierniewice, Kowiesy and Nowy Kawęczyn.

In the geobotanical division of Poland (SzAFER 1977) the park area is located in the Rawa District, covering the south-eastern part of the Mazovian Section, which belongs to the Belt of the Great Valleys and the Baltic Division. Together with the pine and mixed forests is it located outside the occurrence ranges of the beech, sycamore, fir and spruce.

The Bolimów Landscape Park is located in three physicogeographic units. Wysoczyzna Rawska (Rawska High Plain), which covers about $25 \%$ of its area, is distinct due to wavy moraine upland. Its characteristics are well developed slope and valley forms with deeply cut valleys of the Rawka, Chojnatka and Korabiewka Rivers. The altitude of the terrain ranges from $125 \mathrm{~m}$ a.s.l. to $185 \mathrm{~m}$ a.s.l. The south-western, small part of the park and its protection zone occur in Wzniesienia Łódzkie (Lódź Elevation). The area is of upland wavy moraine character with well developed valley and slope forms. There occur there: denudation valleys, dry valleys, periglacial basins and forms developed as a result of aeolic processes. The are of the upland is constructed of stratified sands and fluvioglacial gravels. Równina Łowicko-Błońska (Łowicko-Błońska Plain) constitutes about $70 \%$ of the park area. The terrain of this unit is level, cut by numerous river valleys. In its southern part there are numerous detrital fans, mainly to the east of the Rawka River, between the villages of Kamion and Radziwiłłów (KONDRACKI 1994; KozIEJ 2002).

The morphology of the present park area, which was finally formed in the Tertiary, was affected by several-fold invasion of the Scandinavian continental glacier. The thickness of glacial forms in the Bolimów Landscape Park occasionally exceeds 100 meters (BALIŃSKA-WUTTKE 1960; KLAJNERT 1982). The greatest impact on the sculpture and geologic structure of the surface layers was that of Middle Poland (Riss) glaciation: the Warta stage. In that period a complicated glacial land sculpture, which attained its present form due to erosive and denudation processes occurring in subsequent periods. In the Mazovian interglacial large areas of residual sediments and valley that became filled in with riverine sediments developed (RóżYCKI 1972). The present river network and extensive outwash plains and other forms that appeared as a result of fluvioglacial activity also originated in that period (KLATKOWA 1979). The Eemski interglacial period expressed itself in increased erosion and accumulation, mainly in riverine valleys (among others in the Rawka River valley) (STARKEL 1977). The period of the Baltic glaciation also affected the geology and morphology of the present landscape park. Glacial wedges, involutions and other sediments of various genesis belong to the best known structures of that period (DYLIK 1971; KozIEJ 2002). In the periglacial period the valley network was increased in denudation basins, ravines and floodplain stairs. In that period intensive denudation processes took place. Sediments that resulted from them occur in outflowless depressions and within dunes and aeolian covers. The result of eolian activity are complexes of parabolic dunes in the northern part of BLP (DYLIKOWA 1973; KLATKOWA 1979; KOZIEJ 2002).

The Bolimów Landscape Park is dominated by podsol soils. They occur in complexes with brown soils and cover $85 \%$ of the BLP. The most frequent among them are podsols developed from slightly loamy sands. They are characterized by low humus content, acidity and low fer- 
tility. They occur mainly to the north of the Skierniewice-Mszczonów railway. In riverine valleys there developed mud-bog soils, peat soils and boggy soils, which cover together about $10 \%$ of the park area. They developed in humid habitats, which are mostly exploited as meadows or pastures. The other soil types, including chernozem soils, cover $5 \%$ of the studied area. Chernozems originate from loam and clay/silt of various geological formations and from dust forms of water origin. They were recorded mainly in the north-eastern part of the characterized area (KozIEJ 2002).

Surface water resources of the park are not large. They are estimated at $9.18 \mathrm{~m}^{3} / \mathrm{sek}$ (1.c.). The Rawka is the most important river flowing across the park. Its total length is $101.5 \mathrm{~km}$, including about $44 \mathrm{~km}$ within the park area. Its catchment is $1192 \mathrm{~km}^{2}$ in area. The Rawka discharge at its mouth (village of Kęszyce) is $5.09 \mathrm{~m}^{3} / \mathrm{sek}$, and slope $-1.2 \%$. The Rawka is a strongly meandering river while its catchment is asymmetric. Its right side tributaries are longer. Its largest effluents flowing across the park are: the Białka, Chojnatka, Rokita, Korabiewka and Grabinka. Other rivers flowing across the park are: the Sucha, Sucha Nida, Pisia Gagolina and Okrzesza (OlaCZEK, KUCHARSKI 1994-1995).

Underground waters occur in the park on four geological levels: Jurassic, Cretaceous, Tertiary and Quaternary. The main reservoirs of underground waters occur east of the line joining the towns of Łowicz and of Rawa Mazowiecka. An area poorer in underground water is that between the towns of Skierniewice and of Rawa Mazowiecka (Koziej 2002).

A characteristic feature of the climate in BLP is changeability of atmospheric phenomena in time and space. Climatically, the area may be divided into two zones: lowland in the north (Łowicko-Błońska Plainland) and upland in the south (Rawska High Plain and Łódź Elevation). A border zone with a specific climate occurs between them (1.c.).

The volume of atmospheric precipitation little exceeds the evaporation, which testifies to water deficit in the soil. Evaporation ranges from 500 to $520 \mathrm{~mm}$ per year, while the total annual precipitation is $525 \mathrm{~mm}$ in the north of the park (vicinity of Skierniewice) and $550 \mathrm{~mm}$ in the south - in the border zone of the Rawska High Plain (MISIEWICZ-ŚNIEżKo 1982; KozIEJ 2002). It is an insufficiently moistened area. The lowest precipitation is noted in March and October. The highest deficiency in air humidity was observed in Skierniewice in June and July, while the lowest deficiency from December to February. The snow cover deposition period varies widely from year to year, ranging from 26 to 85 days over a year (KozIEJ 2002).

The vicinities of Skierniewice receive one of the highest rates of solar radiation delivery, amounting to $86.3 \mathrm{Kcal} / \mathrm{cm}^{2}$. The area is considered one of the warmest in Poland (SCHMUCK 1961). July is the warmest month, February is the coldest one.

In the vicinities of Skierniewice wind reaches a mean annual speed of $3.5 \mathrm{~m} / \mathrm{s}$. It is more than in the town of Warsaw $(3.1 \mathrm{~m} / \mathrm{s})$ and less than in the town of Łódź $(4.2 \mathrm{~m} / \mathrm{s})$. Speed and direction of winds close to earth surface are modified by: diverse terrain relief, vegetation, building constructions, communication arteries and other environmental conditions (KozIEJOWA 1998).

\section{MATERIAL AND METHODS}

The object of research was the Bolimów Landscape Park, together with its protection zone. A data base for preparing floristic maps presenting the distribution of vascular plants in this area was created on the basis of materials originating from three sources: published and non-published studies (cited in the Introduction), herbarium materials deposited in the Herbarium Univer- 
sitatis Lodzensis and from floristic field investigations. Unpublished data, mainly from MSc dissertations, were included to the base when they were documented with herbarial collections.

The main source of information were field square sampling (floristic relevés) data obtained in 1996-2000. They were obtained using a background of a topographic map in the scale of 1:50000 with an imposed net of squares. The applied method was that with a regular net of quadrats (FALIŃSKI 1990). The net of squares $1 \mathrm{~km}$ in side length is adjusted to the all-Poland ATPOL net (ZAJAC 1978). 470 squares were sampled during the present investigations (Fig. 1). They are included in eight ATPOL squares (10x10 km) (ED 40, ED 41, ED 42, ED 50, ED 51, ED 52, ED 61, ED 62) each $100 \mathrm{~km}^{2}$ in area (ZAJĄC A., ZAJĄC M. 2001).

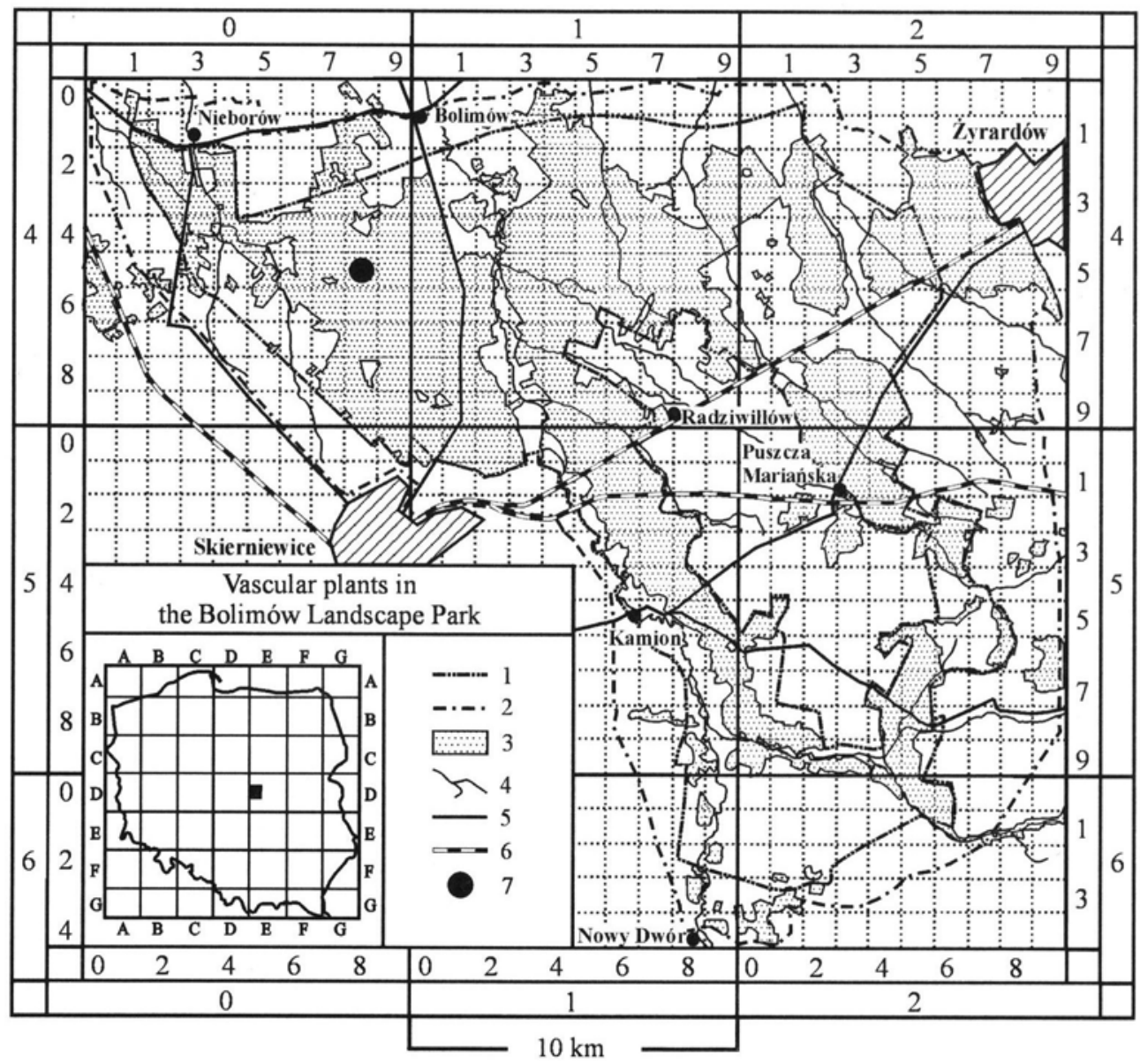

Fig. 1. Guide-map with grid by ATPOL for studies on distribution of vascular plants

1 - border of the Bolimów Landscape Park; 2 - border of protection zone; 3 - forests; 4 - rivers and streams; 5 - roads; 6 - railways; 7 - site point ED 4058

The floristic data base and cartograms were prepared on the basis of special software written for the purpose of the atlas (ROMANIUK 1998).

Lines signifying the borders of BLP are imposed on the cartograms. In the left low corner of the cartogram the following informations are located: ordinal number of species; category of threat to the plant in Central Poland (WARCHOLIŃSKA 1998; JAKUBOWSKA-GABARA, KUCHARSKI 1999); 
category of threat in Poland (ZARZYCKI, SZELĄG 1992); status of legal protection; number of sites (squares). The nomenclature of vascular plant species was accepted after MIREK et al. (1995).

The existing localities are marked on the cartograms by black circles, historical localities by empty circles.

\section{PLANT COMMUNITIES}

Forests occupy about $65 \%$ of BLP, a much smaller are being covered by synanthropic, meadow, bog and water vegetation. Habitats with the last type of vegetation exert the greatest impact on the diversity of plant communities in the park. Stands of the most precious plant associations were detected in glades, which occupy as little as about $1 \%$ of the park area. They are places of the occurrence of over a half of communities recorded in the area of the BLP, among others associations of moor grass meadows and of raised bogs (KUCHARSKI, PISAREK 1998).

The forest vegetation is composed of 20 associations and subassociations as well as several substitution communities. The decisively largest area is occupied by pine forest and mixed forests, which dominate in the northern and north-western part of the Bolimów Landscape Park. The most widespread are phytocoenoses of the subcontinental coniferous fresh forest Peucedano-Pinetum and suboceanic fresh coniferous forest Leucobryo-Pinetum as well as mixed coniferous forest Querco roboris-Pinetum. The marshy coniferous forest Vaccinio uliginosi-Pinetum, humid coniferous forest Molinio-Pinetum and dry coniferous forest CladonioPinetum are rare components of the BLP vegetation. Subcontinental oak-hornbeam forest TilioCarpinetum, despite a small area, is widespread in the whole area of the park. Small areas are also occupied by the carr phytocoenoses. The most frequently encountered is the alder-ash carr Fraxino-Alnetum. The elm carr Ficario-Ulmetum and willow-poplar carr Salici-Populetum are recorded much more rarely. Phytocoenoses of current alderwood Ribeso nigri-Alnetum were noted mostly at the near-edge zone of the Rawka River valley. Oakwoods are very rare in BLP. The xerothermic oakwood Potentillo albae-Quercetum was recorded in the north-eastern part of the park, while small stands of the acidiphilic oakwood Calamagrostio-Quercetum in various parts of BLP (JAKUBOWSKA-GABARA 2002).

Non-forest vegetation is represented by the phytocoenoses of meadow, psammophilous grassland, rush, bog, segetal and ruderal. They are created by the phytocoenoses of 90 plant associations and communities, 25 of which are meadow communities, 23 rush communities, 25 segetal and ruderal communities and 17 units representing the vegetation of bogs and waters. Of the floristically poor water vegetation Wolffietum arrhizae deserves particular attention. Rush and bog vegetation is created by numerous communities. They include rare and threatened associations. Particular attention should be paid to Caricetum elatae, Caricetum appropinquatae, Caricetum rostratae, Caricetum lasiocarpae, Caricetum diandrae, Caricetum hartmanii, Calamagrostietum neglectae and Eriophoro vaginati-Sphagnetum recurvi (KUCHARSKI 2002).

Meadows, which occupy less than $10 \%$ of the BLP area, are overgrown by stands of most of plant vegetation communities recorded in Central Poland (KUCHARSKI 1999). This is the place where moor grass meadows Molinietum caeruleae and Junco-Molinietum and a rare association of Polygono bistortae-Trollietum europaei may be recorded. Arrhenatheretum elatioris, Angelico-Cirsietum and Lolio-Cynosuretum were also observed in the park (KUCHARSKI 2002).

Psammophilous grasslands are composed of the phytocoenoses Spergulo-Corynephoretum 
canescentis. Stands of three subassociations of this community: Spergulo-Corynephoretum canescentis typicum, S.-C. cladinetosum mitis, $S$.- $C$. thymetosum serpylli were recorded in the park. A very rare component of the vegetation are well developed stands of Diantho-Armerietum (CZYŻEWSKA 2002).

Synanthropic habitats of BLP are overgrown by the phytocoenoses of 25 plant associations and one community, including 10 segetal associations and one segetal community. The most precious segetal syntaxa noted in the park are: the community of Saxifraga tridactylites, GalioRanunculetum arvensis and Papaveretum argemones. Ruderal communities are represented, among others, by: Panico-Eragrostietum, Corispermo-Brometum tectorum, Centaureo-Berteroëtum and Balloto-Chenopodietum (WARCHOLIŃSKA 2002).

\section{FLORA}

A high diversity of the Bolimów Landscape Park habitats results in a richness and diversified flora of the area. 1049 vascular plant taxa were recorded there. They include 51 species covered by legal protection and a group of 126 species mentioned in the Polish and regional lists of threatened and endangered species (WARCHOLIŃSKA 1986-1987; ZARZYCKI, SzELĄG 1992; JAKUBOWSKA-GABARA, KUCHARSKI 1999).

The oldest publication, the data of which have been considered in the present study, is that of VocKE (1857). From 25 species listed by that author from the vicinities of the village of

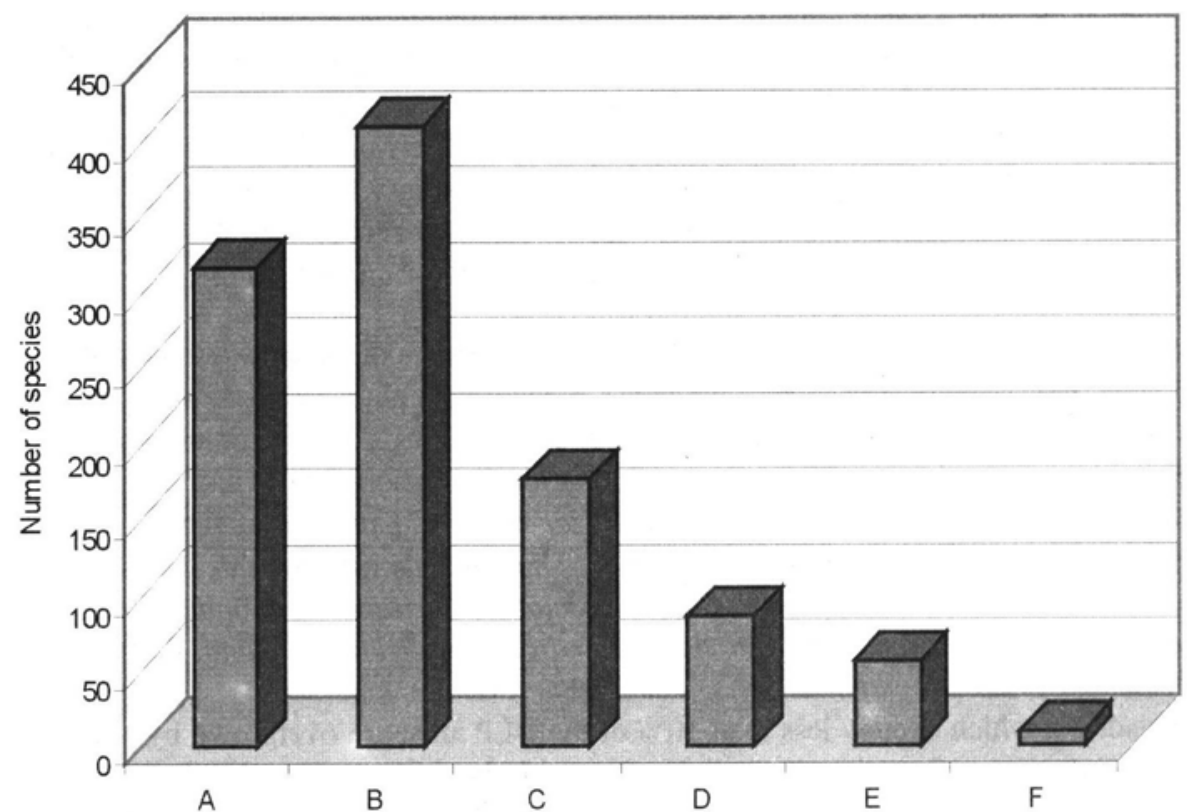

Fig. 2. Frequent occurrence of vascular plant species in the Bolimów Landscape Park A-F - number of sites (squares); A-1-10, B-11-100, C-101-200, D-201-300, E-301-400, F-more than 400 
Nieborów, 8 were not determined during the present investigations. These are Arctostaphylos uva-ursi, Carex buxbaumii, C. tomentosa, Leersia oryzoides, Potentilla collina, Pulsatilla patens, $P$. vernalis, Senecio paludosus.

The analysis of the vascular plants frequent occurrence shows that rare species are the most numerous, while common species are not much (Fig. 2).

The largest group, which comprises over 600 taxa, is the flora of forests. The most precious species recorded in the stands of the xerothermic oakwood. Particular attention is deserved by Asperula tinctoria, Festuca amethystina, Melittis melisophyllum, Potentilla alba, Pulmonaria angustifolia, Ranunculus polyanthemos, Vicia cassubica. In the forests and woods of BLP, 34 protected species were determined, among them Chimaphila umbellata, Digitalis grandiflora, Diphasiastrum complanatum, Hierochloë odorata, Platanthera bifolia and others (JAKUBOWSKA-GABARA, KUCHARSKI, WARCHOLIŃSKA 2002).

A high diversity is also displayed by the flora of non-forest habitats. The vegetation of meadows and bogs in the park comprises over 470 species of vascular plants. Despite the area of their habitats not exceeding $10 \%$ of the area of the park over $30 \%$ of the total number of vascular plant species of BLP occur there. Particular attention is deserved by the protected species of Dianthus superbus, Gentiana pneumonanthe, Iris sibirica, Ophioglossum vulgatum, Pedicularis sylvatica, Polemonium coeruleum and Trollius europaeus. A considerable group are also species that are rare and threatened in the scale of Poland or the region. They are, among others, Carex cespitosa, C. hartmanii, Filipendula vulgaris, Teucrium scordium, Thalictrum flavum, Veronica teucrium, Vicia pisiformis, Wolffia arrhiza. The synanthropic flora of BLP is also precious. Its richness is affected by: diversity of habitats, their spatial arrangement diversity and size diversity, extensive methods of management used in agriculture in the area of the park, development of recreation and settlement and the vicinity of towns (Skierniewice and Żyrardów). Rare and threatened species are also recorded in the group, among them Gagea pratensis, Illecebrum verticillatum, Lappula squarrosa, Marrubium vulgare, Nigella arvensis, Polycnemum arvense (JAKUBOWSKA-GABARA, KUCHARSKI, WARCHOLIŃSKA 2002).

The vascular flora of BLP is dominated by native species, which constitute $75.2 \%$ of the total taxa number. Allochthonous species - anthropophytes, which are 261, constitute the remaining $24.8 \%$.

The location of the park in the middle part of Poland, where there are occurrence limits of various species makes the plants occurring there represent various geographical elements of the Polish flora and various occurrence range groups. Mountainous flora is represented by e.g. Anthriscus nitida, Calamagrostis villosa and Huperzia selago. Species of the northern, boreal limit are represented by Carex vaginata and Linnaea borealis. Western species (subatlantic element) are Carex umbrosa, Corynephorus canescens, Galium saxatile, Hypericum humifusum, Spergula morisonii and Teesdalea nudicaulis. To continental species of eastern occurrence limit belong, e.g., Carduus acanthoides, Carex pilosa, Chamaecytisus ruthenicus, Echium vulgare and Ranunculus cassubicus.

Among synanthropic plants, Irano-Turanian, Lithospermum arvense, Malva neglecta, Veronica persica and Mediterranean ones, Amaranthus lividus and Raphanus raphanistrum, were recorded. The sites of numerous species in the terrain of the park are important because of phytogeographic reasons, as they occur on their occurrence limits or outside them, for example the sites of certain synanthropic plants located at their north-eastern occurrence limits, Centunculus minimus, Herniaria hirsuta and Radiola linoides.

Particular attention should be paid to those species in the vascular flora of the park that are very rare even in the scale of Poland. These include those mentioned in the "Polish Red Plant Bo- 
ok": Carex vaginata, Festuca amethystina, Ostericum palustre, Succisella inflexa (KAźMIERCZAKOWA, ZARZYCKI 2001), and endangered and vulnerable ones of Andromeda polifolia, Juncus atratus, Kickxia elatine, Lolium remotum, Lolium temulentum, Pulmonaria angustifolia, Scutellaria hastifolia and Viola stagnina (JAKUBOWSKA-GABARA, KUCHARSKI, WARCHOLIŃSKA 2002).

\section{REFERENCES}

Bogulewska, T. 1980. Flora doliny Rawki w okolicy wsi Stara Rawa. Maszynopis pracy magisterskiej. Katedra Geobotaniki i Ekologii Roślin Uniw. Łódzkiego, Łódź.

BALIŃSKA-WUTTKE, K. 1960. Geomorfologia obszaru między Skierniewicami a Rawą Mazowiecką. Prace Geogr. Instytutu Geografii PAN 23: 7-103.

CZYŻEWSKA, K. 1992. Syntaksonomia śródlądowych, pionierskich muraw napiaskowych [Syntaxonomy of inland and pioneer psammophilous grasslands]. Monogr. Bot. 74: 1-174 (in Polish with English summary).

CzYżEwSKA, K. 1998. Kategorie Czerwonej Listy [The IUCN Red List categories]. W: CzYżEwSKA, K. (red.). Różnorodność biologiczna porostów [Lichen biological diversity]. Wyd. Uniw. Łódzkiego, Łódź: 29-43 (in Polish with English summary).

CZYŻEwSKA, K. 1999. Murawy napiaskowe Bolimowskiego Parku Krajobrazowego [Psammophilous grassland of the Bolimów Nature Park]. Monogr. Bot. 85: 211-232 (in Polish with English summary).

CzYŻEwSKA, K. 2002. Roślinność napiaskowa. W: JAKUBOwSKA-GABARA J., MARKowSKI J. (red.). Bolimowski Park Krajobrazowy. Monografia przyrodnicza. Regionalne Centrum Edukacji Ekologicznej, Łódź: 38-40.

DUSZYŃSKA, M. 1998. Różnorodność fitocenotyczna lasów liściastych uroczyska „Bartnica” w Bolimowskim Parku Krajobrazowym. Maszynopis pracy magisterskiej. Katedra Geobotaniki i Ekologii Roślin Uniw. Łódzkiego, Łódź.

DYLIK, J. 1971. Województwo ze stolicą bez antenatów. ŁTN, Łódź.

DYLIKowa, A. 1973. Geografia Polski. Krainy geograficzne. PZWS, Warszawa.

DzIADEK, B. 1969. Charakterystyka florystyczno-fitosocjologiczna borów mieszanych i sosnowych uroczyska „Grabina”. Maszynopis pracy magisterskiej. Katedra Geobotaniki i Ekologii Roślin Uniw. Łódzkiego, Łódź.

FALIŃSKI, J.B. 1990. Kartografia geobotaniczna. Cz. 1. PPWK, Warszawa-Wrocław.

GłowACIŃSKI, Z. 1997. Nowe kategorie IUCN/WCU dla gatunków zagrożonych i ginących. Chrońmy Przyr. Ojcz. 53, 1: $60-66$.

GolonKA, Z. 1927. Łąki i pastwiska południowo-wschodniej części dorzecza Bzury (powiat skierniewicki). Rocz. Nauk Roln. i Leśn. 16: 257-336.

IRCHA, M. 1996. Flora i waloryzacja przyrodniczo-krajobrazowa doliny Rawki na odcinku Kamion-Budy Grabskie, Maszynopis pracy magisterskiej. Katedra Ochrony Przyrody Uniw. Łódzkiego, Łódź.

JAKUBOWSKA-GaBARA, J. 1978. Materiały do flory Wysoczyzny Rawskiej [Materials to the flora of Wysoczyzna Rawska]. Acta Univ. Lodz., Zesz. Nauk. UŁ, Ser. 2, 20: 257-308 (in Polish with English summary).

Jakubowska-Gabara, J. 1980. Dokumentacja rezerwatu leśnego „Puszcza Mariańska”. Maszynopis. Wojewódzki Konserwator Przyrody, Skierniewice.

JAKUBOWSKA-GABARA, J. 1985. Zespoły leśne Wysoczyzny Rawskiej i ich antropogeniczne zniekształcenia [Forest associations of the Rawa Mazowiecka Upland and their anthropogenic deformations]. Monogr. Bot. 65 : 5-147 (in Polish with English summary).

JAKUBOwSKA-GABARA, J. 1987. Notatki florystyczne z doliny Rawki i terenów przyległych [Floristical notes from the Rawka valley and adjoining areas]. Acta Univ. Lodz., Folia Bot. 5: 41-49 (in Polish with English summary).

Jakubowska-GabarA, J. 1988. Distribution of Carex vaginata Tausch in Poland. Acta Soc. Bot. Pol. 57, 2: 287-298. JAKUBOwSKA-GaBARA, J. 1990. Notatki florystyczne z doliny Rawki i terenów przyległych. Cz. II [Floristical notes from the Rawka valley and adjoining areas. Part II]. Acta Univ. Lodz., Folia Bot. 7: $35-45$ (in Polish with English summary).

JAKUBOWSKA-GABARA, J. 1992. Wpływ gospodarki zrębowej na zbiorowiska leśne rezerwatu Puszcza Mariańska [Impact of clearing management of the forest communities of the Puszcza Mariańska reserve]. Acta Univ. Lodz., Folia Bot. 9: 3-22 (in Polish with English summary).

JakubowSKa-Gabara, J. 1994. Distribution of Festuca amethystina L. subsp. Ritschlii (Hackel) Lemke ex Markg.Dannenb. in Poland. Acta Soc. Bot. Pol. 63: 87-95. 
JAKUBOWSKA-GaBARA, J. 1996. Studium florystyczno-fitosocjologiczne rezerwatu „Puszcza Mariańska”. Maszynopis. Wojewódzki Konserwator Przyrody, Skierniewice.

JaKubowSKa-GaBara, J. 1999. Roślinność leśna Bolimowskiego Parku Krajobrazowego [Forest vegetation of Bolimów Nature Park]. Monogr. Bot. 85: 27-98 (in Polish with English summary).

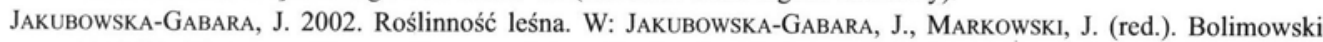
Park Krajobrazowy. Monografia przyrodnicza. Regionalne Centrum Edukacji Ekologicznej, Łódź: 26-32.

JAKUBOWSKA-GABARA, J., KUCHARSKI, L. 1981. Dokumentacja projektowa rezerwatu rzecznego „Rawka”. Maszynopis. Wojewódzki Konserwator Przyrody, Skierniewice.

JAKUBOWSKA-GABARA, J., KUCHARSKI, L. 1983. Rzeka Rawka, projektowany rezerwat przyrody [The Rawka stream a projected nature reserve]. Chrońmy Przyr. Ojcz. 39,1-2: 17-28 (in Polish with English summary).

JAKUBOWSKA-GABARA, J., KUCHARSKI, L. 1999. Ginące i zagrożone gatunki flory naczyniowej zbiorowisk naturalnych i półnaturalnych Polski środkowej [Endangered and threatened vascular plants in natural and seminatural communities in Central Poland]. Fragm. Flor. Geobot. Ser. Polonica 6: 55-74 (in Polish with English summary).

JAKUBOWSKA-GABARA, J., KUCHARSKI, L., WARChOliŃSKA, A.U. 2002. Flora naczyniowa W: JAKUBOWSKA-GABARA, J., MARKowSKI, J. (red.). Bolimowski Park Krajobrazowy. Monografia przyrodnicza. Regionalne Centrum Edukacji Ekologicznej, Łódź: 48-55.

JAKUBOWSKA-GABARA, J., ŁuCZAK, A. 2002. Szata roślinna rezerwatu leśnego „Puszcza Mariańska” oraz jej zmiany po 17 latach ochrony [Plant cover of Puszcza Mariańska forest reserve and its changes after 17 years]. Parki nar. Rez. przyr. 21, 2: 135-158 (in Polish with English summary).

JakUbowSKa-GabarA, J., PISAREK, W. 1997. Materiały do flory naczyniowej Polski Środkowej [Updated information on the vascular flora of Central Poland]. Fragm. Flor. Geobot. Ser. Polonica 4: 9-17 (in Polish with English summary).

JAKUBOWSKA-Gabara, J., ZielińSKA, K. 2001. Distribution of the species of Festuca ovina group. (Poaceae) in the Bolimów Nature Park forest (Central Poland) and remarks on their variability. In: FrEY, L. (ed.). Studies on grasses in Poland. Kraków: 195-200.

JAROSZ, S. 1976. Krajobrazy Polski i ich pierwotne fragmenty. Arkady, Warszawa.

KaźmiercZakowa, R., ZarZyCKI, K. (red.). 2001. Polska Czerwona Księga Roślin. Paprotniki i rośliny kwiatowe [Polish Plant Red Data Book]. Instytut Botaniki im. W. Szafera PAN, Kraków (in Polish and English).

KLAJNERT, Z. 1982. Budowa geologiczna. W: Gregorowicz, J. (red.). Województwo skierniewickie. Monografia regionalna. Wydawnictwo Uniw. Łódzkiego, Łódź-Skierniewice: 15-23.

KLatKowa, H. 1979. Główne etapy plejstoceńskiej ewolucji rzeźby regionu łódzkiego. Acta Univ. Lodz., Folia Geogr. 21: $81-94$ (in Polish with English summary).

KNAPEK, E. 1981. Dokumentacja fitosocjologiczna rezerwatu „Kopanicha”. Maszynopis pracy magisterskiej. Katedra Geobotaniki i Ekologii Roślin Uniw. Łódzkiego, Łódź.

KONDRACKI, J. 1994. Geografia Polski. Mezoregiony fizycznogeograficzne. PWN, Warszawa.

KozIEJ, L. 2002. Środowisko geograficzne. W: JAKuBowSKA-GabARA, J, MarkowSKi, J. (red.). Bolimowski Park Krajobrazowy. Monografia przyrodnicza. Regionalne Centrum Edukacji Ekologicznej, Łódź: 9-24.

KozIEJOWA U. 1998. Klimat. W: KUROWSKI, J. K (red.). Park Krajobrazowy Wzniesień Łódzkich. Eko-Wynik, Łódź: 30-32

KuCHARSKI, L. 1995. Rezerwat łąkowo-torfowiskowy „Polana Siwica”. Dokumentacja projektowa. Maszynopis. Wojewódzki Konserwator Przyrody, Skierniewice.

KUCHARSKI, L. 1997. Roślinność łąk w województwie skierniewickim i jej zmiany w bieżącym stuleciu [Meadows vegetation in the Skierniewice Voivodeship and its transformation in the present century]. Przegląd Przyr. 8, 1-2: 63-72 (in Polish with English summary).

KUCHARSKI, L. 1999. Szata roślinna łąk Polski Środkowej i jej zmiany w XX stuleciu [The plant cover of Central Poland meadows and its changes in the $20^{\text {th }}$ century]. Wyd. Uniw. Łódzkiego, Łódź (in Polish with English summary).

KUCHARSKI, L. 2002. Roślinność łąk i mokradeł. W: JAKUBowSKA-GABARA, J., MARKowSKI, J. (red.). Bolimowski Park Krajobrazowy. Monografia przyrodnicza. Regionalne Centrum Edukacji Ekologicznej, Łódź: 32-40.

Kucharski, L., PISAReK, W. 1998. Polany Puszczy Bolimowskiej [The glades Bolimów Woodland (Puszcza Bolimowska)]. Dyrekcja Bolimowskiego Parku Krajobrazowego, Skierniewice (in Polish with English summary).

KUChARSKI, L., PISAREK, W. 1999. Roślinność łąk Bolimowskiego Parku Krajobrazowego [Vegetation of meadows of the Bolimów Nature Park]. Monogr. Bot. 85: 139-176 (in Polish with English summary).

Kulisiewicz, A. 1981. Dokumentacja florystyczna rezerwatu „Kopanicha”. Maszynopis pracy magisterskiej. Katedra Geobotaniki i Ekologii Roślin Uniw. Łódzkiego, Łódź.

KurZaC, M., KuCharSKI, L. 1990-1991. Pomnikowe drzewa w Polsce Środkowej [Monuments of Nature in Central Poland]. Rocz. Dendr. 39: 61-68 (in Polish with English summary). 
KurZaC, M., PISAREK, W. 1994. Rezerwat krajobrazowo-leśny „Dolina Grabinki”. Dokumentacja projektowa. Maszynopis. Wojewódzki Konserwator Przyrody, Skierniewice.

Kurzac, M., Kurzac, T., Olaczek, R., Jakubowska-Gabara, J., Pisarek, W. 1987. Materiały przyrodnicze do projektu Bolimowskiego Parku Krajobrazowego. Maszynopis. Wojewódzki Konserwator Przyrody, Skierniewice.

MACIAK, I. 1997. Flora naczyniowa Lasu Bolimowskiego i zarys jej analizy ekologicznej. Maszynopis pracy magisterskiej. Katedra Geobotaniki i Ekologii Roślin Uniw. Łódzkiego, Łódź.

Mirek, Z., Pif̨Kó́-Mırkowa, H., ZaJąc, A., ZaJąc, M. 1995. Vascular plants of Poland a checklist [Krytyczna lista roślin naczyniowych Polski]. Pol. Bot. Stud. 15: 1-33 (in English and Polish).

MisiewiCZ-ŚNIESZKo, Ł. 1982. Klimat. W: GREGorowicz, J. (red.). Województwo skierniewickie. Monografia regionalna. Wyd. Uniw. Łódzkiego, Łódź-Skierniewice: 26-34.

Mowszowicz, J. 1960. Conspectus florae lodziensis. ŁTN, Prace Wydz. III 69: 1-375.

Mowszowicz, J. 1978. Conspectus florae Poloniae Medianae (plantae vasculares). Przegląd flory Polski Środkowej (rośliny naczyniowe). Wyd. Uniw. Łódzkiego, Łódź.

OLACZEK, R. 1963. Niektóre rzadkie lub nowe gatunki roślin dla flory woj. łódzkiego [Same interesting plants from territory of Central Poland]. Zesz. Nauk. UŁ, Ser. 2 14: $73-79$ (in Polish with English summary).

OLACZEK, R. 1971. Nasza przyroda. Przewodnik po województwie łódzkim. LOP, Warszawa.

OLACZEK, R. 1972. Formy antropogenicznej degeneracji leśnych zbiorowisk roślinnych w krajobrazie rolniczym Polski Niżowej. Wyd. Uniw. Łódzkiego, Łódź

Olaczek, R. 1974. Materiały do flory Polski Środkowej [New materials to the flora of Central Poland]. Zesz. Nauk. UŁ, Ser. 2 54: 27-39 (in Polish with English summary).

Olaczek, R., Jakubowska-Gabara, J., Pisarek, W. 1988. Wielosił błękitny Polemonium coeruleum w Puszczy Bolimowskiej. Chrońmy Przyr. Ojcz. 44, 6: 61-63.

OlaCZEK, R., KuChARSKI, L. 1994-1995. Rezerwat wodny rzeka „Rawka”. Plan Ochrony na lata 1996-2015. Cz. I. Operat planu ochrony. Cz. II. Dokumentacja naukowa. Maszynopis. Wojewódzki Konserwator Przyrody, Skierniewice.

Olaczek, R., KurZaC, M. 1979a. Dokumentacja rezerwatu leśnego „Ruda-Chlebacz”. Maszynopis. Wojewódzki Konserwator Przyrody, Skierniewice.

OlaczeK, R., KurZaC, M. 1979b. Dokumentacja rezerwatu leśnego „Kopanicha”. Maszynopis. Wojewódzki Konserwator Przyrody, Skierniewice.

Olaczek, R., PISAReK, W. 1987. Projekt rezerwatu łąkowo-torfowiskowego „Polany Puszczy Bolimowskiej”. Maszynopis. Wojewódzki Konserwator Przyrody, Skierniewice.

OWCZAREK, M. 1997. Szata roślinna doliny Rokity i jej aspekt sozologiczny. Maszynopis pracy magisterskiej. Katedra Geobotaniki i Ekologii Roślin Uniw. Łódzkiego, Łódź.

PAJąk, A. 2001. Różnorodność gatunkowa flory naczyniowej uroczyska „Mokra” w Bolimowskim Parku Krajobrazowym. Maszynopis pracy magisterskiej. Katedra Geobotaniki i Ekologii Roślin Uniw. Łódzkiego, Łódź.

PISAREK, W. 1984. Szata roślinna polan Puszczy Bolimowskiej i jej przemiany pod wpływem antropopresji. Maszynopis pracy magisterskiej. Katedra Geobotaniki i Ekologii Roślin Uniw. Łódzkiego, Łódź.

PISAREK, W. 1989. Flora polan Puszczy Bolimowskiej i jej aspekt sozologiczny [Flora of the Bolimów Forest glades and its sozological aspect (Central Poland)]. Fragm. Flor. Geobot. 36, 1-2: 81-100 (in Polish with English summary).

PiSAREK, W., KuCharSki, L. 1999. Roślinność szuwarowa i torfowiskowa Bolimowskiego Parku Krajobrazowego [Reedswamp and peatbog vegetation of Bolimów Nature Park]. Monogr. Bot. 85: 99-137 (in Polish with English summary).

Popow, S. 2001. Różnorodność gatunkowa flory naczyniowej uroczyska „Grabina” w Bolimowskim Parku Krajobrazowym. Maszynopis pracy magisterskiej. Katedra Geobotaniki i Ekologii Roślin Uniw. Łódzkiego, Łódź.

RoMANIUK, P. 1998. Instrukcja obsługi bazy danych „Flora”. Maszynopis. Katedra Geobotaniki i Ekologii Roślin Uniw. Łódzkiego, Łódź.

RóżYCKı, S. Z. 1972. Plejstocen Polski środkowej na tle przeszłości w górnym trzeciorzędzie. Warszawa.

RUSZCZYŃSKA, M. 1998. Różnorodność fitocenotyczna borów sosnowych i mieszanych uroczyska „Bartnica” w Bolimowskim Parku Krajobrazowym. Maszynopis pracy magisterskiej. Katedra Geobotaniki i Ekologii Roślin Uniw. Łódzkiego, Łódź.

SchmucK, A. 1961. Regiony termiczne w Polsce. Czas. Geogr. 2: 21-36.

SelıgA, A. 2002. Waloryzacja przyrodnicza i krajobrazowa doliny Rawki na odcinku Budy Grabskie-Ziemiary. Maszynopis pracy magisterskiej. Katedra Ochrony Przyrody Uniw. Łódzkiego, Łódź.

SowA, R. 1971. Flora i roślinne zbiorowiska ruderalne na obszarze województwa łódzkiego ze szczególnym uwzględnieniem miast i miasteczek. Wyd. Uniw. Łódzkiego, Łódź.

Starkel, L. 1977. Paleogeografia holocenu. PWN, Warszawa. 
Szafer, W. 1977. Szata roślinna Polski Niżowej. W: Szafer, W., Zarzycki, K. (red.). Szata roślinna Polski. T. II. PWN, Warszawa: 17-188.

TYszKowSKA, A. 1994. Flora naczyniowa Nieborowa. Maszynopis pracy magisterskiej. Katedra Geobotaniki i Ekologii Roślin Uniw. Łódzkiego, Łódź.

TYSZKowSKA, B. 1994. Flora naczyniowa Bolimowa, Bolimowskiej Wsi i Kolonii Bolimowskiej Wsi. Maszynopis pracy magisterskiej. Katedra Geobotaniki i Ekologii Roślin Uniw. Łódzkiego, Łódż.

VOCKE, A. 1857. Eine Correspondenz von Nieborow in Russich-Polen. Oest. Bot. Wochenblatt. 17: 139.

WARCHOLIŃSKA, A.U. 1982. Zbiorowiska segetalne zbóż ozimych Skierniewic i terenów przyległych. [Segetal communities of winter cereal of the Skierniewice and adjacent areas]. Acta Agrobot. 34: 285-300 (in Polish with English summary).

WARCHOLIŃSKA, A.U. 1986-1987. Lista zagrożonych gatunków roślin segetalnych środkowej Polski [A list of endangered segetal plant species in Central Poland]. Fragm. Flor. Geobot. 31-32, 1-2: 225-231 (in Polish with English summary).

WARChOLIŃSKA, A.U. 1988-1990. Roślinność segetalna terenów rolniczych Puszczy Bolimowskiej i jej współczesne przemiany [Segetal plants of agricultural areas of Bolimów Primeval Forest and its contemporary transformations]. Acta Agrobot. 41, 2: 369-452 (in Polish with English summary).

WARChOLIŃSKA, A.U. 1997a. Flora i roślinność segetalna Bolimowskiego Parku Krajobrazowego. Część I. Flora segetalna [Flora and segetal vegetation of the Bolimów Nature Park. Part I. Segetal flora]. Acta Agrobot. 50, 1-2: 125-139 (in Polish with English summary).

WARChOLIŃSKA, A.U. 1997b. Flora i roślinność segetalna Bolimowskiego Parku Krajobrazowego. Część II. Flora segetalna [Flora and segetal vegetation of the Bolimów Nature Park. Part II. Segetal flora]. Acta Agrobot. 50, 12: 141-162 (in Polish with English summary).

WARCHOLIŃSKA, A.U. 1998. Właściwości zagrożonych segetalnych roślin naczyniowych Polski. [Features of threatened segetal flora species in Central Poland and possibility of their protection]. Acta Univ. Lodz.. Folia Bot. 13: 7-14 (in Polish with English summary).

WARChOLIŃSKA, A.U. 1999. Roślinność synantropijna Bolimowskiego Parku Krajobrazowego [The synanthropic vegetation of Bolimów Nature Park]. Monogr. Bot. 85: 177-210 (in Polish with English summary).

WARChOLIŃSKA, A.U. 2002. Roślinność synantropijna W: JAKUBOWSKA-GABARA, J. MARKOWSKI, J. (red.). Bolimowski Park Krajobrazowy. Monografia przyrodnicza. Regionalne Centrum Edukacji Ekologicznej, Łódź: 40-47.

WietesKA, B. 1984. Flora i roślinność nadrzecznych pasów łęgowych rzeki Rawki w Puszczy Bolimowskiej. Maszynopis pracy magisterskiej. Katedra Geobotaniki i Ekologii Roślin Uniw. Łódzkiego, Łódź.

WIŚNIEWSKA, K. 1997. Zbiorowiska leśne uroczyska „Bolimów” oraz ich ekologiczne i antropogeniczne zróżnicowanie. Maszynopis pracy magisterskiej. Katedra Geobotaniki i Ekologii Roślin Uniw. Łódzkiego, Łódź.

WIŚNIEWSKI, J. 1965. Niektóre rzadsze chwasty powiatu łowickiego [Certaines plantes ruderales assez apparaissant sur le territoire in district de Łowicz]. Zesz. Nauk. UŁ, Ser. 2, 18: 131-134 (in Polish with French summary).

WIŚNIEWSKI, J. 1974. Chwasty polne woj. łódzkiego [Field weeds of the Łódź Voivodship]. Zesz. Nauk. UŁ, Ser. 254 : 41-45 (in Polish with English summary).

WIŚNIEWSKI, J. 1976a. Chwasty polne północnych obszarów województwa łódzkiego. Cz. III [Field weeds in northern area of the Łódź Province (3-rd part)]. Acta Univ. Lodz., Zesz. Nauk. UŁ, Ser. 2 2: 49-58 (in Polish with English summary).

WIŚNIEWSKI, J. 1976b. Chwasty polne północnych obszarów województwa łódzkiego. Cz. IV [Field weeds in northern area of the Łódź Province (4-nd part)]. Acta Univ. Lodz., Zesz. Nauk. UŁ, Ser. 2 8: 17-29 (in Polish with English summary).

WOJCIECHOWSKA, M. 1969. Lasy dębowe oraz zbiorowiska wtórne na siedliskach lasów dębowych w uroczysku „Grabina”. Maszynopis pracy magisterskiej. Katedra Geobotaniki i Ekologii Roślin Uniw. Łódzkiego, Łódź.

WOLAŃSKA, A. 1996. Roślinność i waloryzacja turystyczno-gospodarcza doliny Rawki na odcinku Kamion-Budy Grabskie. Maszynopis pracy magisterskiej. Katedra Ochrony Przyrody Uniw. Łódzkiego, Łódź.

ZAJACC, A. 1978. Założenia metodyczne „Atlasu rozmieszczenia roślin naczyniowych w Polsce”. Wiad. Bot. 22, 3: 145-155.

ZAJAC, A., ZAJAC, M. (red). 2001. Atlas rozmieszczenia roślin naczyniowych w Polsce [Distribution atlas of vascular plants in Poland]. Pracownia Chorologii Komputerowej Instytutu Botaniki Uniw. Jagiellońskiego, Kraków (in Polish and English).

ZARZYCKI, K., SzelAG, Z. 1992. Czerwona lista roślin naczyniowych zagrożonych w Polsce [Red list of threatened vascular plants in Poland] W: ZARZYCKI, K., WojewODA, W., HeinRich, Z. (red.). Lista roślin zagrożonych w Polsce [List of threatened plants in Poland]. Instytut Botaniki im. W. Szafera PAN, Kraków: 87-98 (in Polish with English summary).

ZiELONY, R. 1990. Forest associations of the Puszcza Mariańska reserve. Ann. of Warsaw Agricult. Univ. SGGW 40: 61-67. 
Bolimowski Park Krajobrazowy (BPK) powstał w 1986 roku. W jego granicach znalazł się największy w południowo-wschodniej części Mazowsza kompleks leśny zwany Puszczą Bolimowską. Charakterystyczną cechą puszczy jest obecność licznych śródleśnych polan. Duże zróżnicowanie siedlisk decyduje o bogactwie i różnorodności zbiorowisk roślinnych i flory tego obszaru.

Rozmieszczenie, stwierdzonych na terenie BPK gatunków roślin naczyniowych, opracowano głównie na podstawie wyników terenowego kartowania florystycznego, przeprowadzonego w latach 1996-2001. Badania wykonano stosując metodę pól regularnych. Przyjęto lokalną sieć kwadratów o boku $1 \mathrm{~km}$, dostosowaną do ogólnopolskiej sieci ATPOL. Obszar parku i jego otuliny podzielono na 470 kwadratów o powierzchni $1 \mathrm{~km}^{2}$, które wchodzą w skład ośmiu kwadratów ATPOL-u (ED40, ED41, ED42, ED50, ED51, ED52, ED61, ED62) o boku $10 \mathrm{~km}$. Mapy rozmieszczenia taksonów wykonano na podstawie bazy danych do której wprowadzono wszystkie informacje $\mathrm{z}$ bezpośrednich badań terenowych, a także dane z prac opublikowanych i nieopublikowanych (zob. Wstęp) oraz materiałów zielnikowych znajdujących się w Herbarium Universitatis Lodziensis (LOD).

Na terenie Bolimowskiego Parku Krajobrazowego stwierdzono 1049 taksonów roślin naczyniowych. Stanowiska ośmiu gatunków podanych przez VOCKE (1857), a obecnie nie stwierdzonych, mają charakter historyczny. We florze BPK dominują gatunki rodzime, które stanowią 75,2\% ich ogólnej liczby. Dużym bogactwem gatunkowym oraz obecnością bardzo interesujących taksonów wyróżniają się fitocenozy leśne, łąkowe i torfowiskowe.

We florze naczyniowej parku stwierdzono 51 gatunków chronionych oraz 126 ginących i zagrożonych w skali regionu i kraju. Na szczególną uwagę zasługują rośliny uwzględnione w Czerwonej Ksiedze Roslin (KAźMIERCZAKOWA, ZARZYCKI 2001): Carex vaginata, Festuca amethystina i Ostericum palustre. W skali regionu interesujące są stanowiska takich gatunków jak: Digitalis grandiflora, Diphasiastrum complanatum, Gymnadenia conopsea, Hierochloë odorata, Huperzia selago, Illecebrum verticillatum, Iris sibirica, Juncus atratus, Kickxia elatine, Lolium remotum, L. temulentum, Nigella arvensis, Polemonium coeruleum, Polycnemum arvense, Pulmonaria angustifolia, Scutellaria hastifolia, Trollius europaeus, Vicia pisiformis, Viola stagnina i Wolffia arrhiza.

Stanowiska niektórych rzadko występujących gatunków posiadają ważną rangę ze względów fitogeograficznych. Ich stanowiska na terenie BPK znajdują się bowiem przy granicy zasięgu lub nawet daleko poza nią. Do takich gatunków należą: Anthriscus nitida, Calamagrostis villosa, Carex pilosa, C. umbrosa, Centunculus minimus, Herniaria hirsuta, Linnaea borealis i Radiola linoides. 
DISTRIBUTION ATLAS OF THE VASCULAR PLANTS 
Alphabetical arrangement of species has been adopted in the atlas.

- presently existing sites

O - historical sites

Information in the left low corner of the cartogram: ordinal number of species - 1-1049;

Category of threat to the plant in Central Poland after the IUCN Red List Categories (1994; see GŁOWACIŃSKI 1997; CZYŻEWSKA 1998): EX - Extinct; EW - Extinct in the Wild; CR Critically Endangered; EN - Endangered; VU - Vulnerable; LR - Low Risk; cd - conservation dependent, nt - near threatened, lc - least concern; DD - Data Deficient; NE - Not Evaluated. Category of threat in Poland after the IUCN Red Data Book Categories (ZARZYCKI, SzeląG 1992): Ex - Extinct and probably extinct; E - Endangered; V - Vulnerable; R - Rare; I Indeterminate.

Ch. - species covered by strict protection;

Ch. cz. - species covered by partial protection.

$\mathrm{n}=5-$ number of sites 

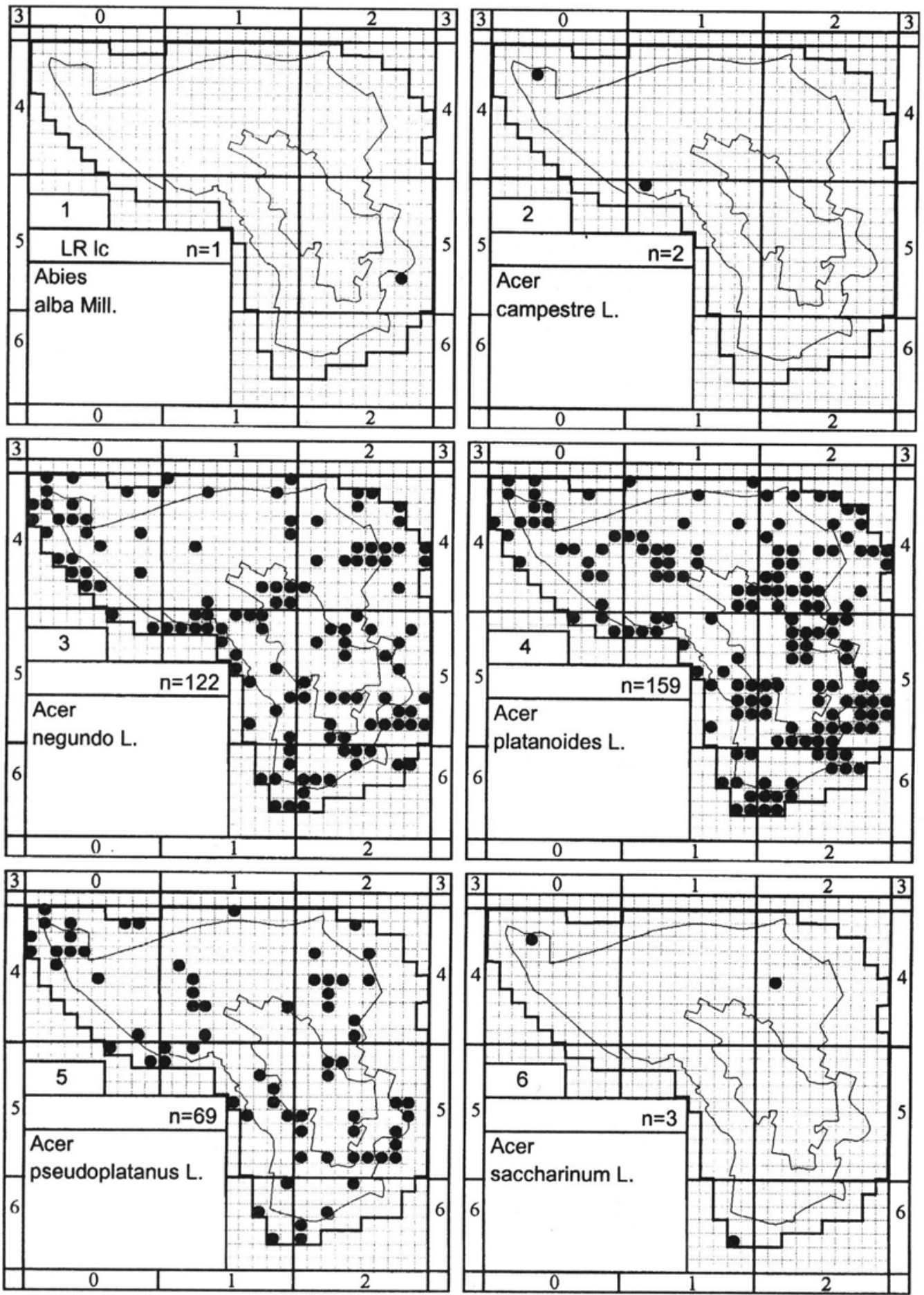


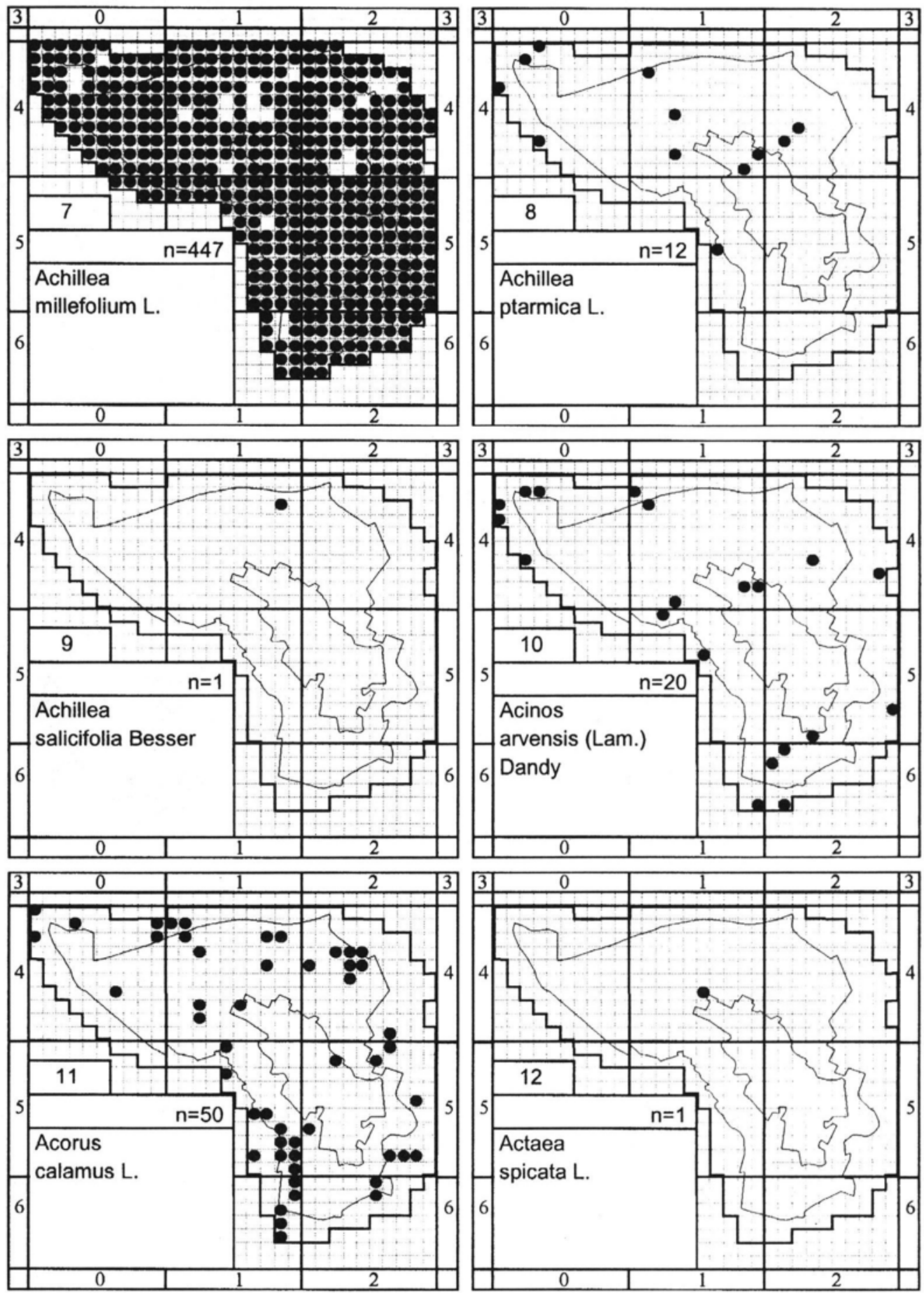



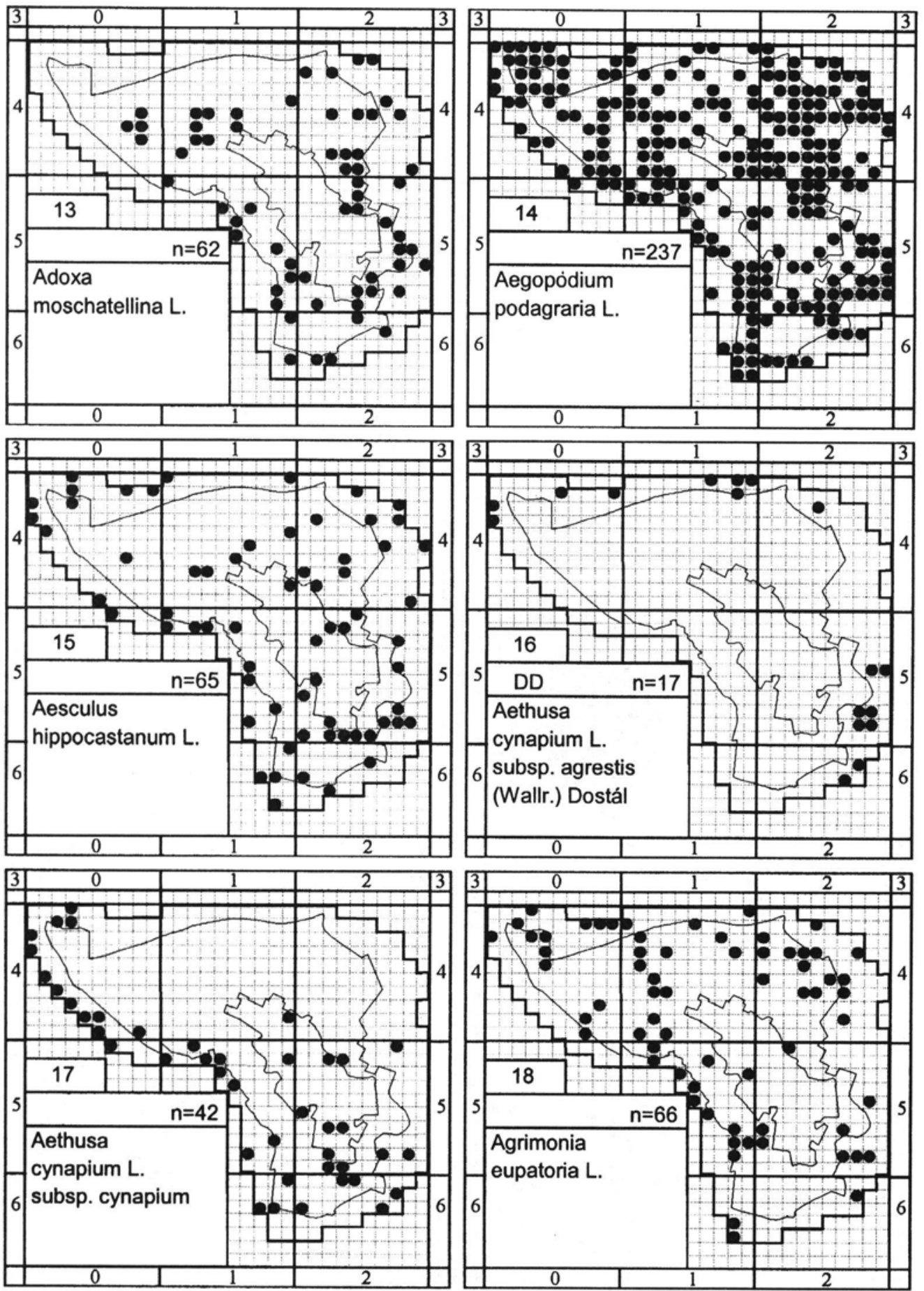

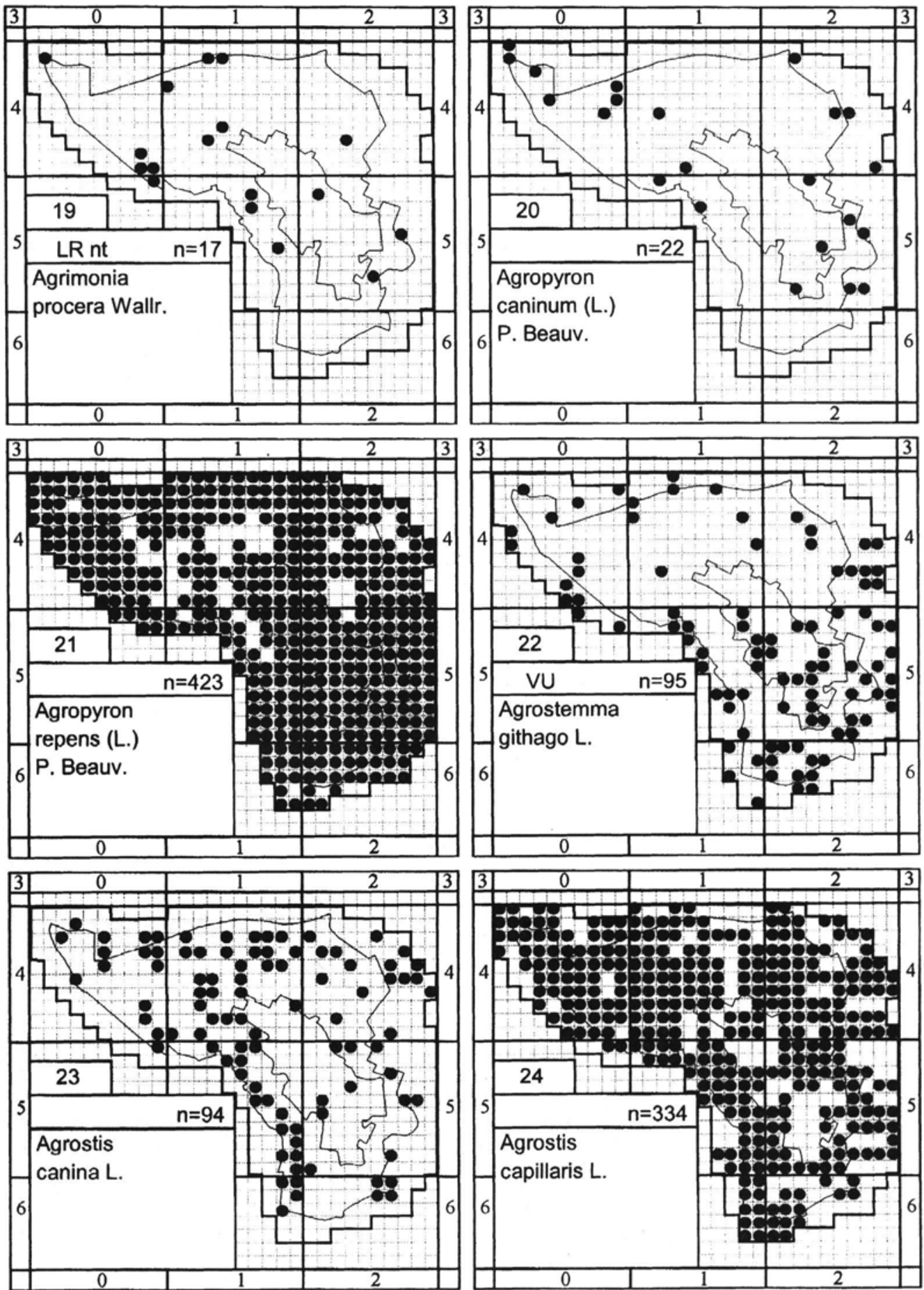


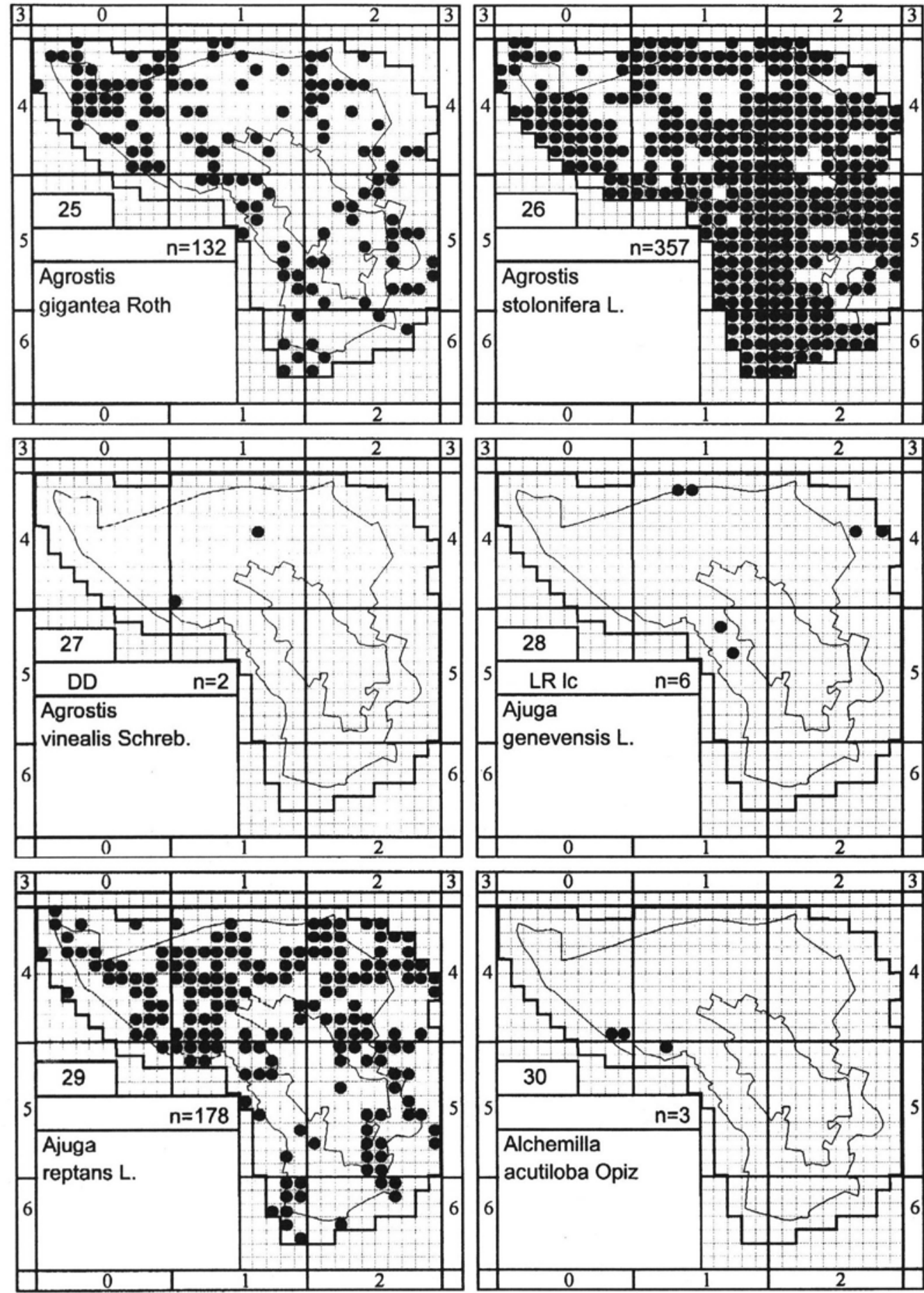



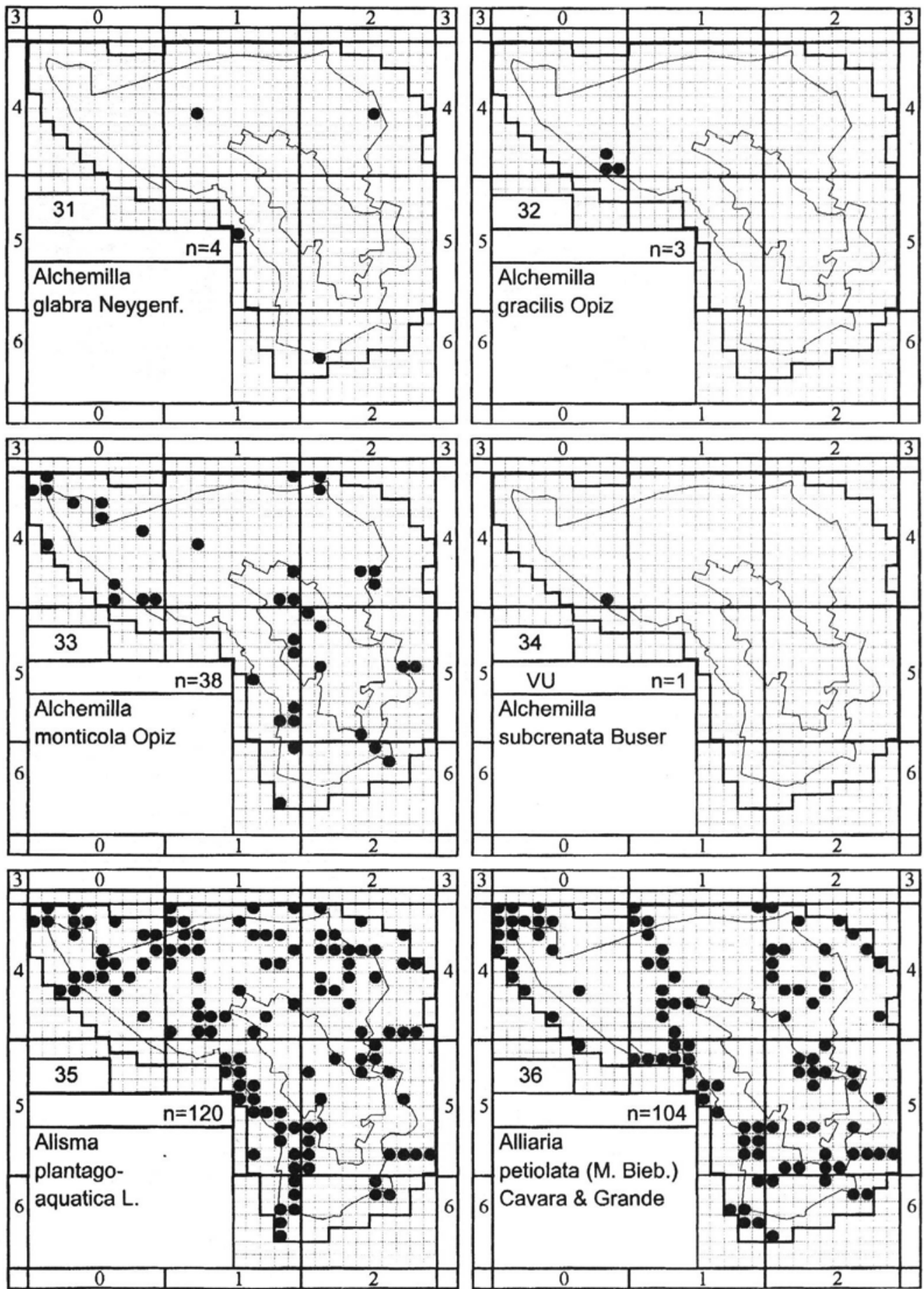

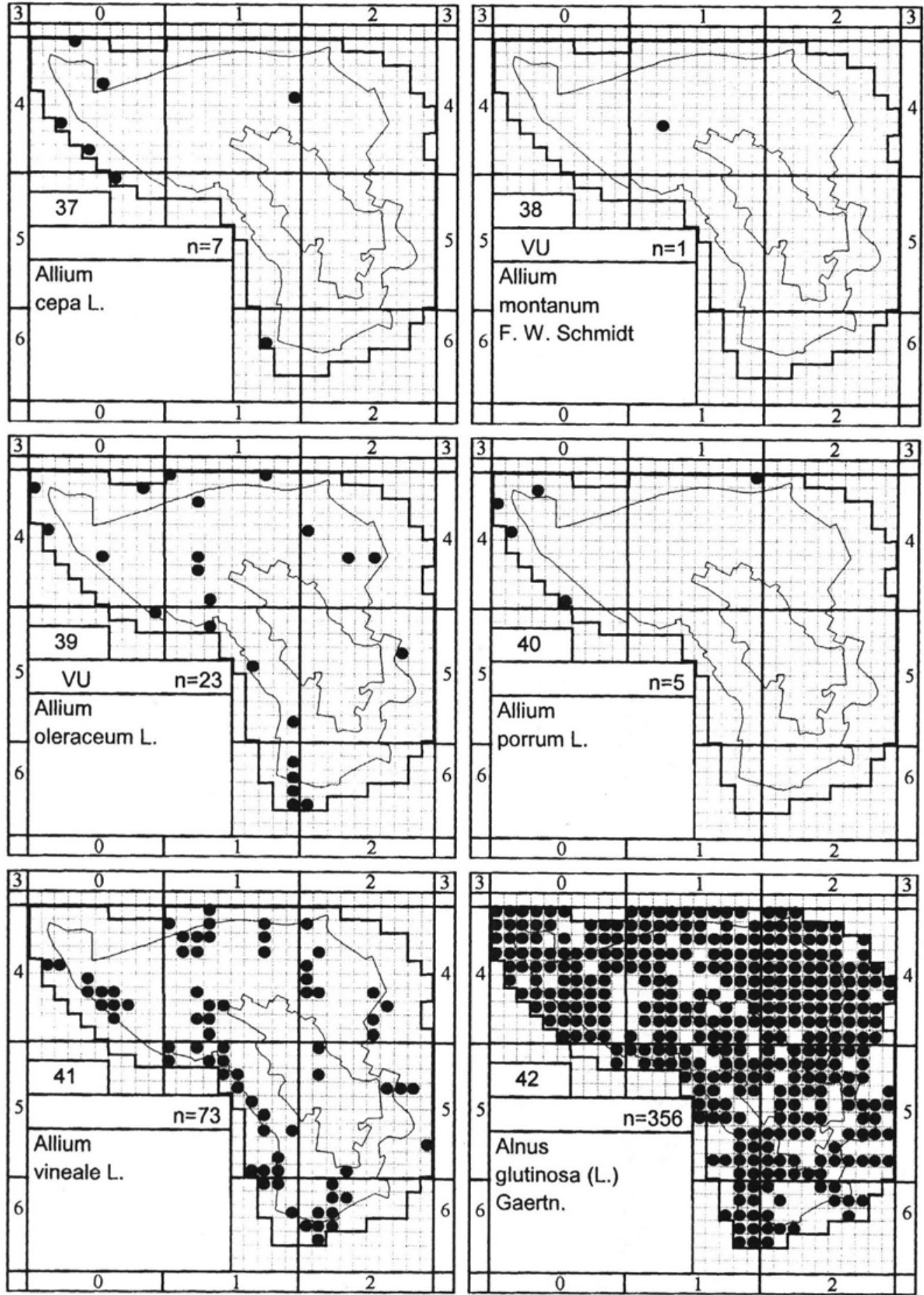

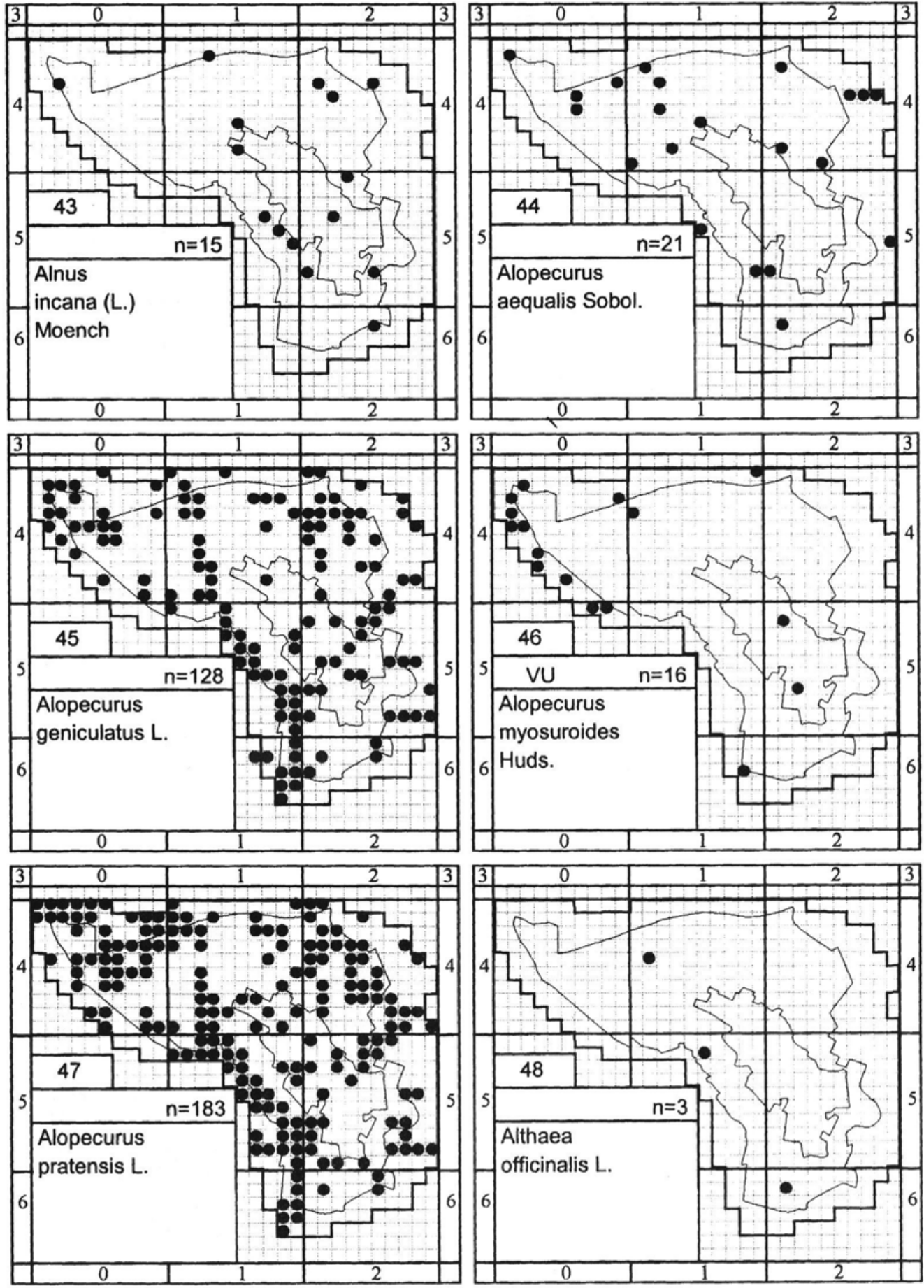

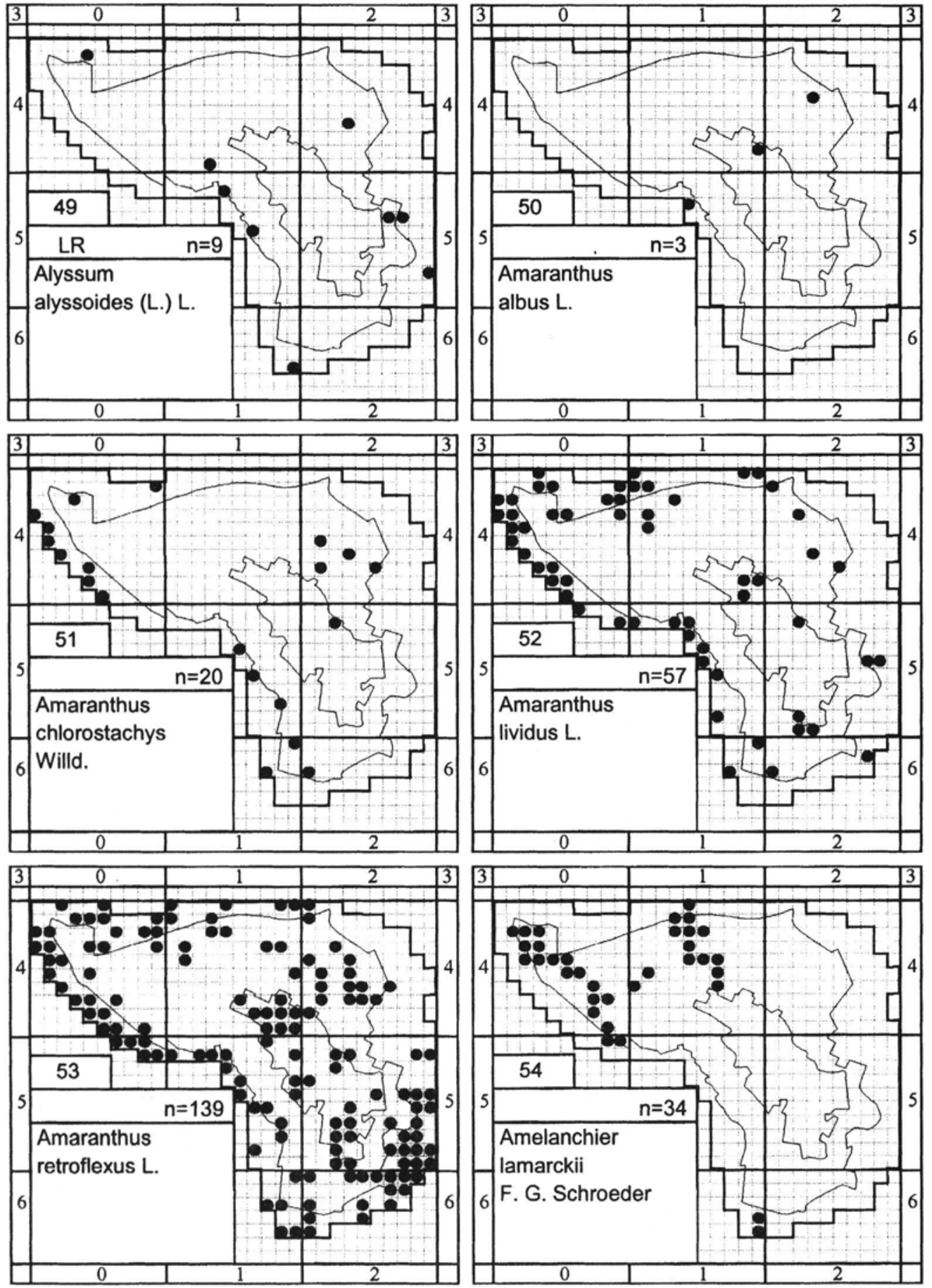

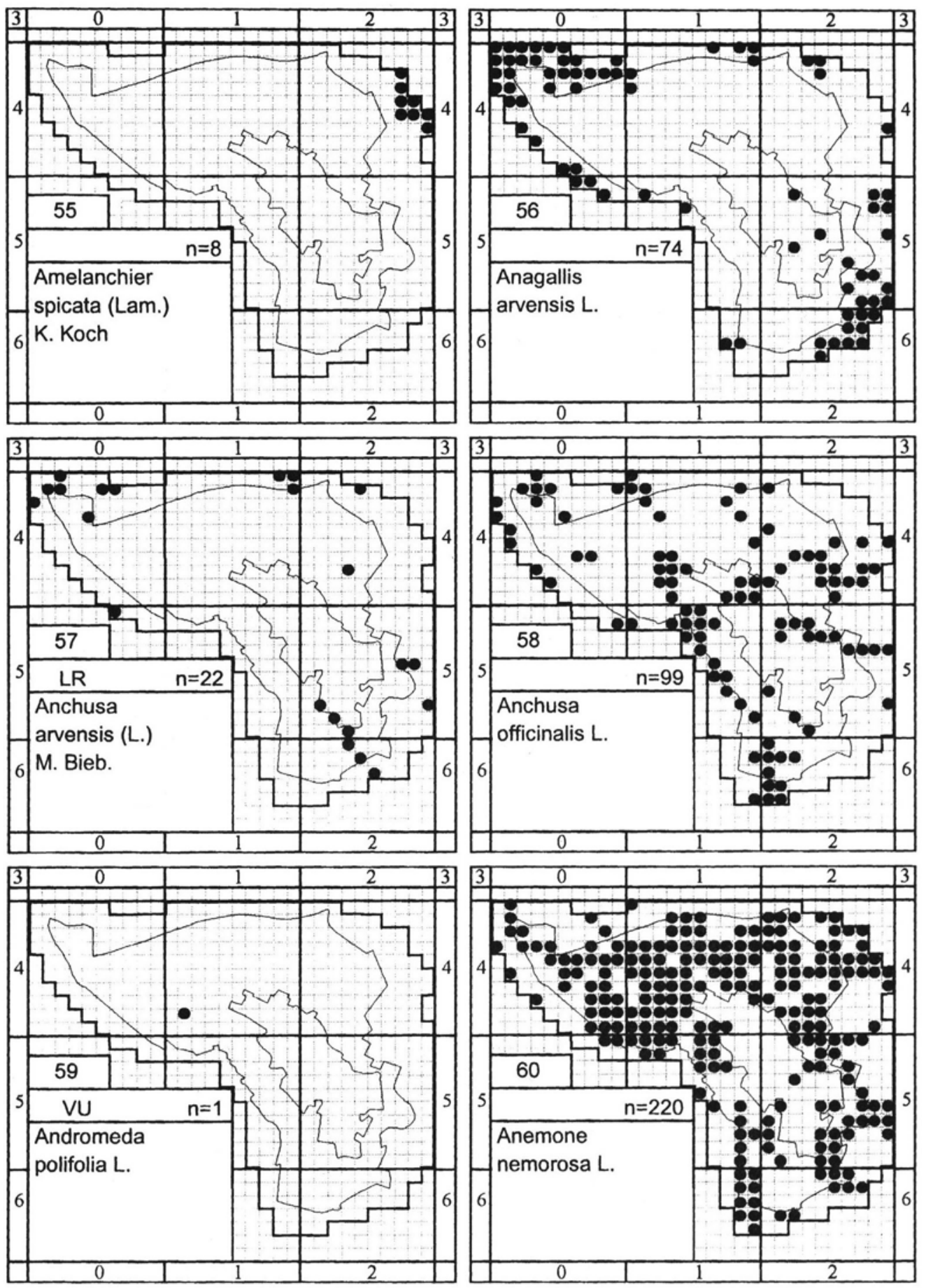

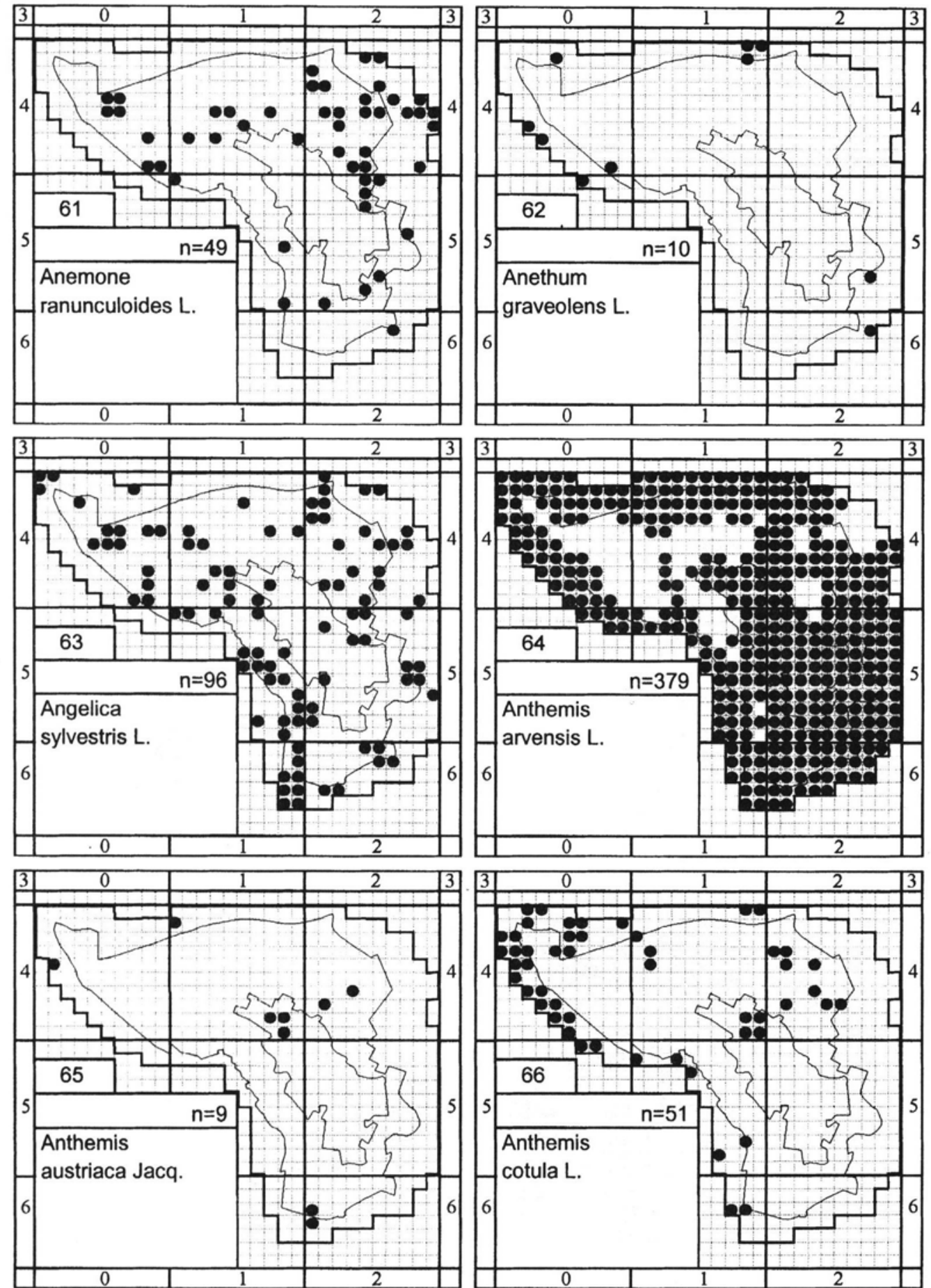

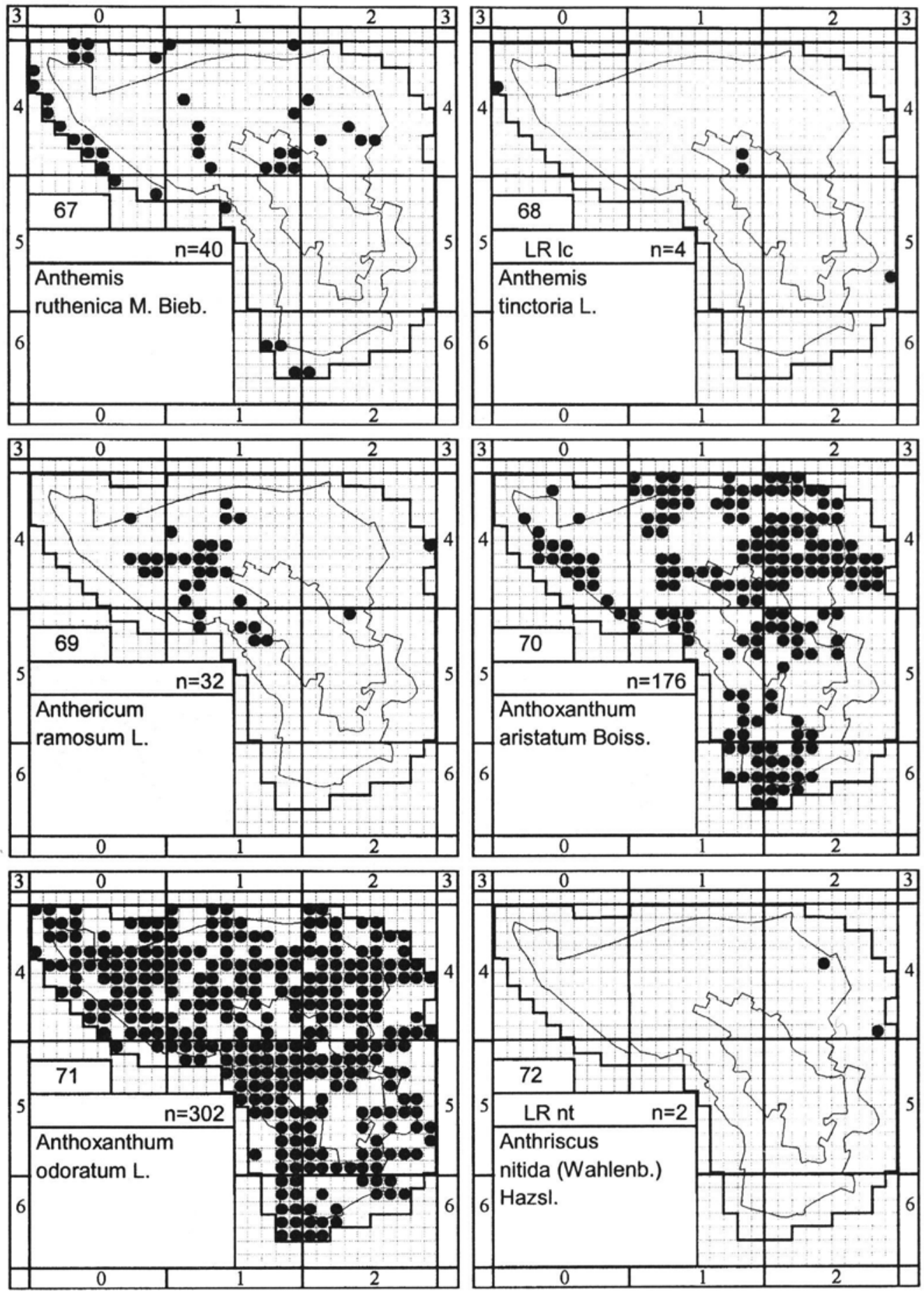


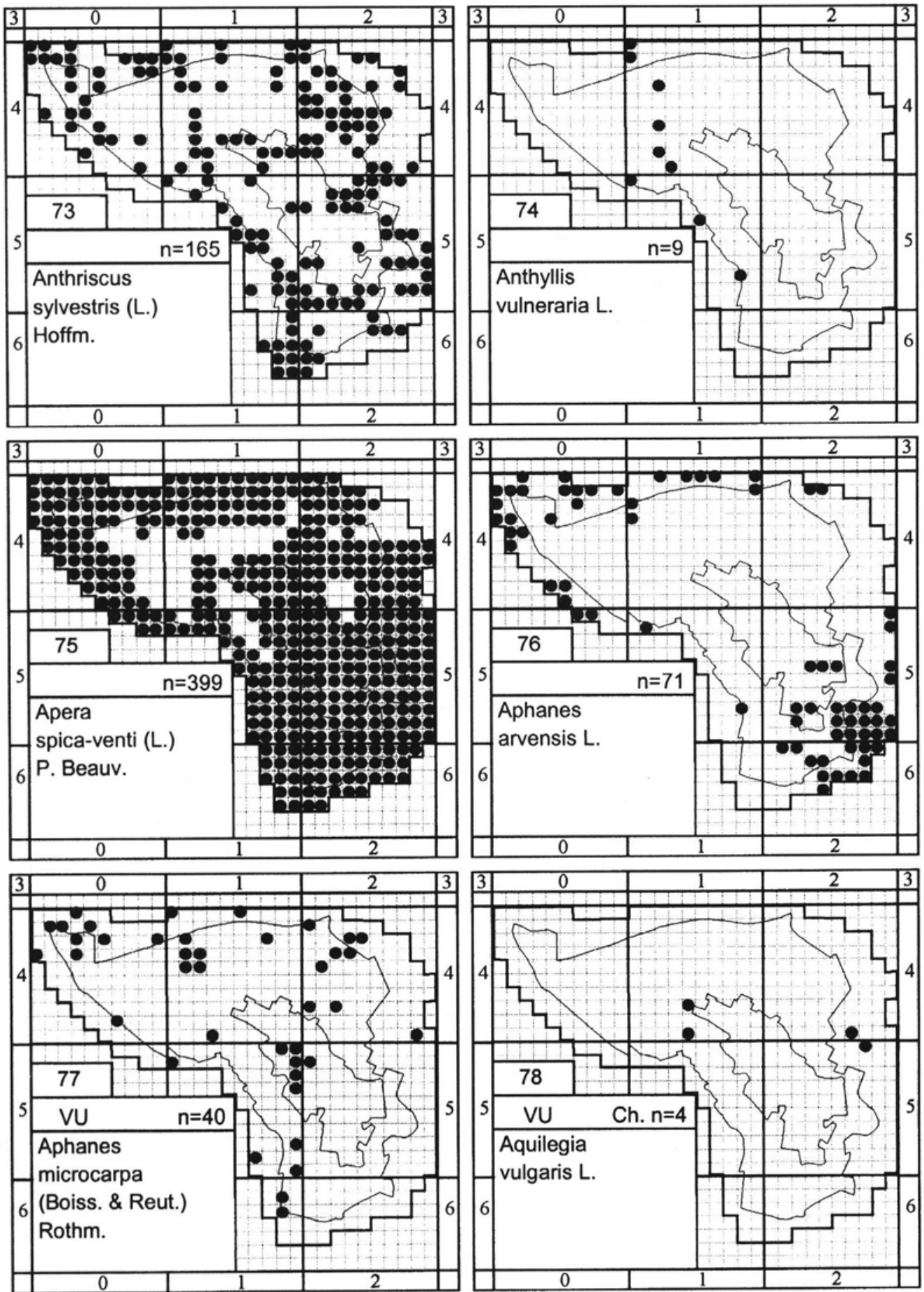



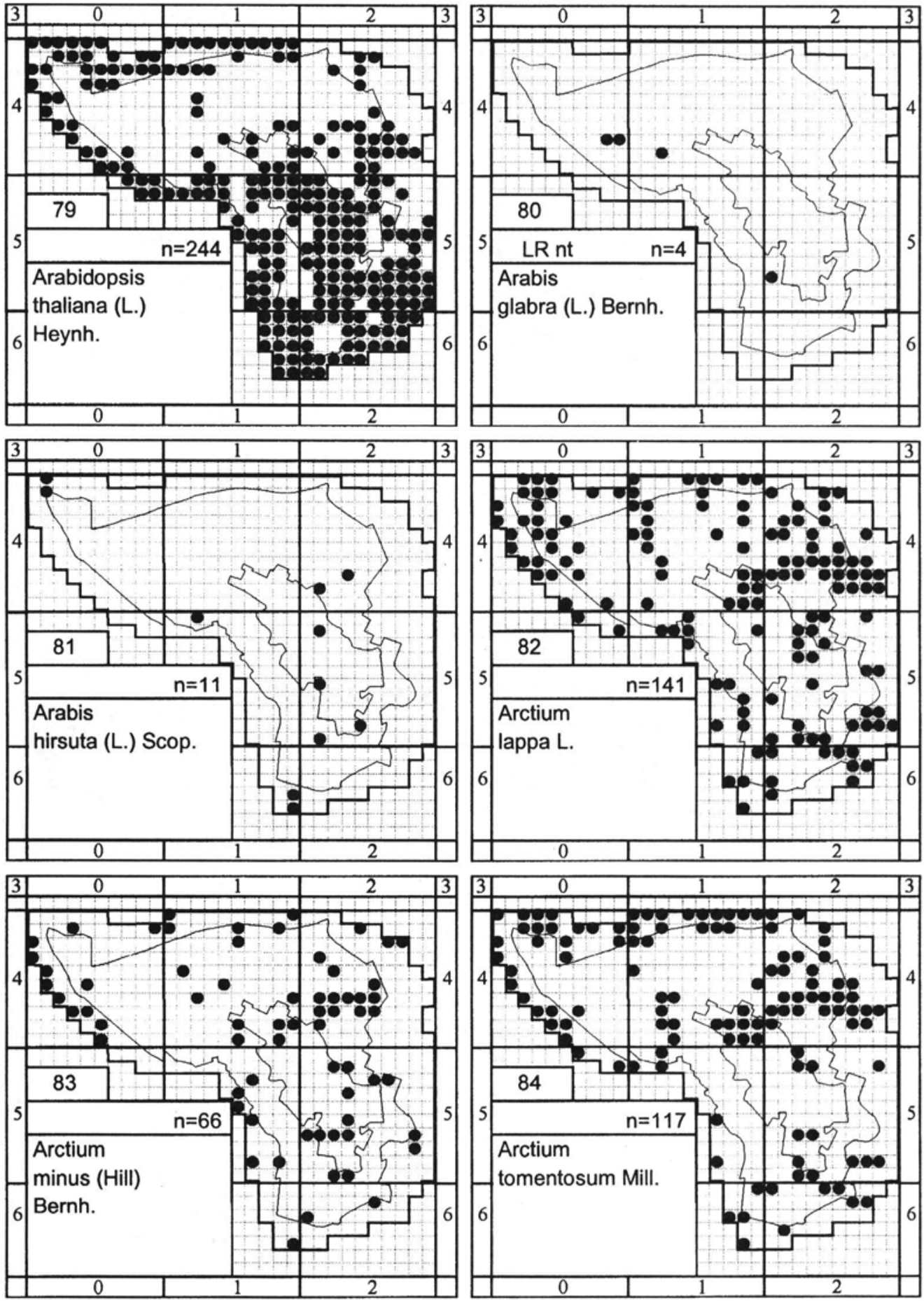

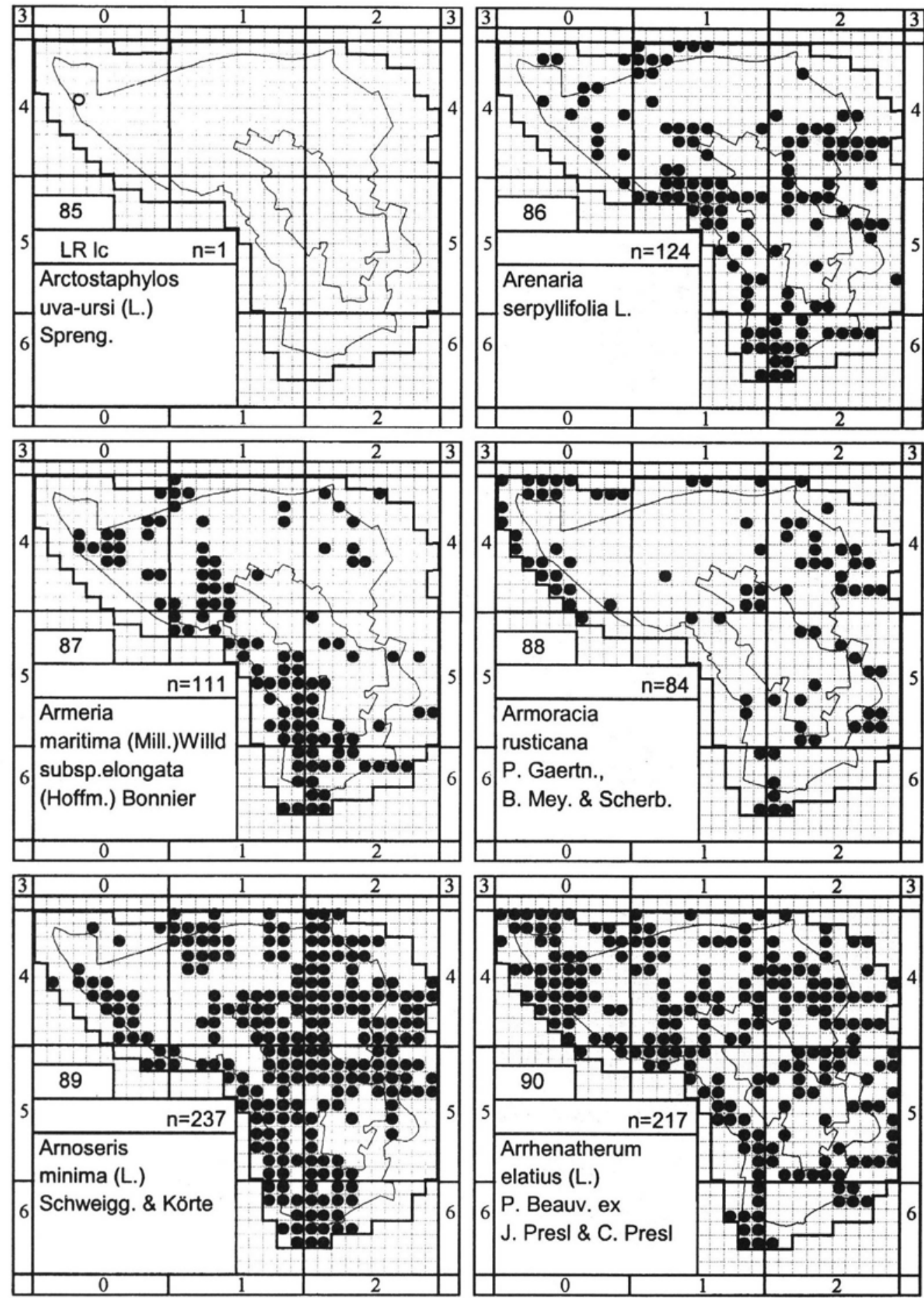

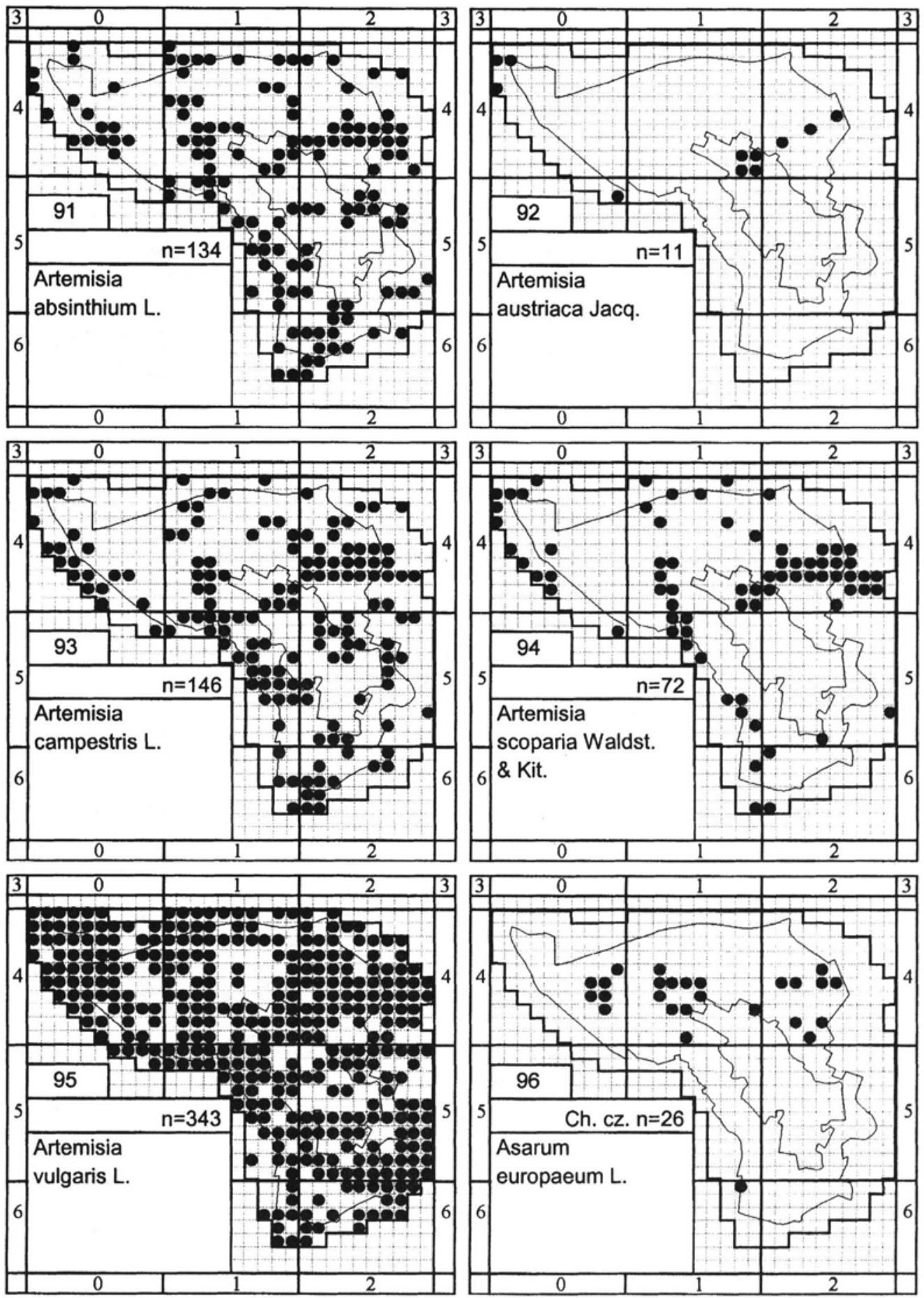


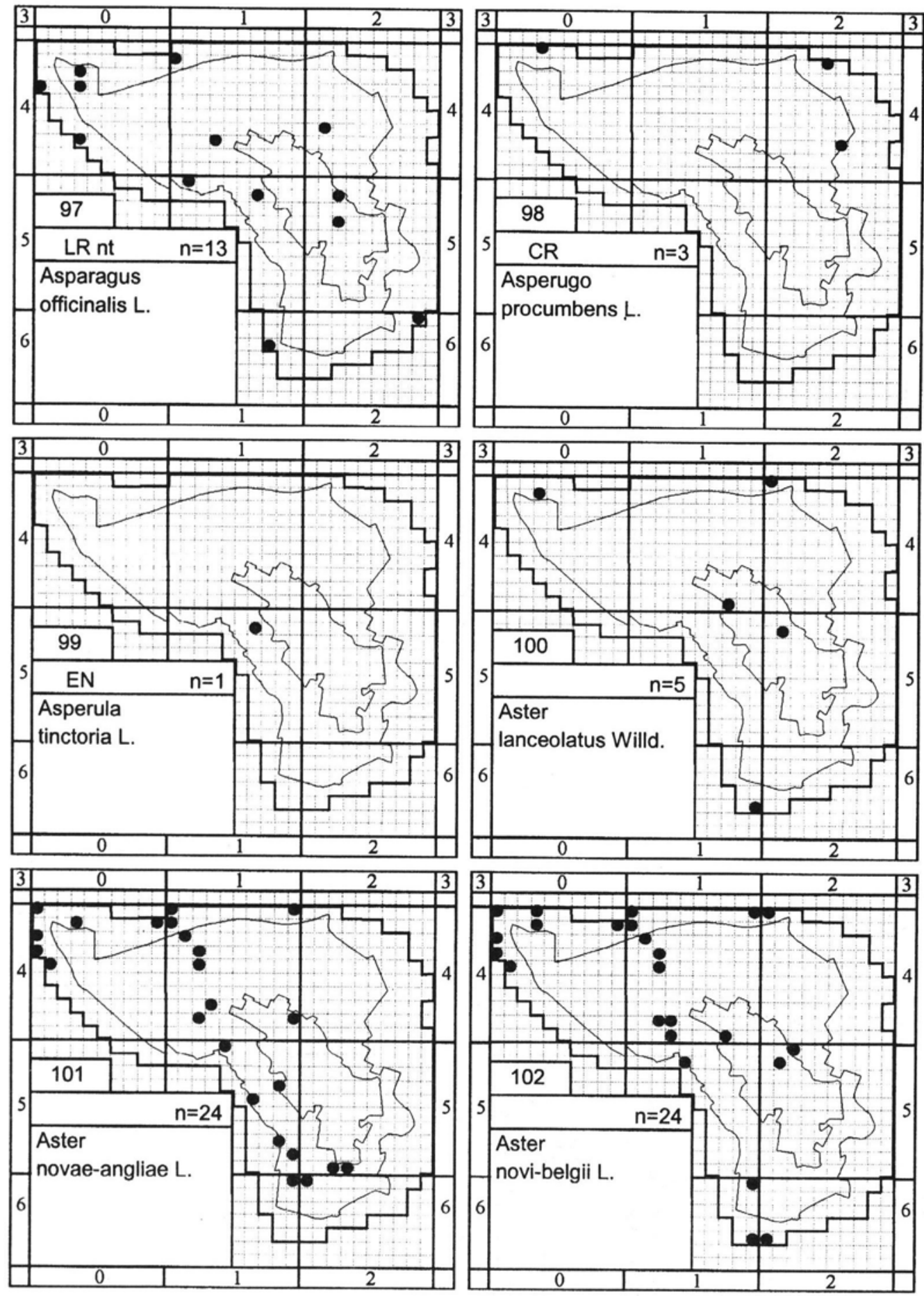



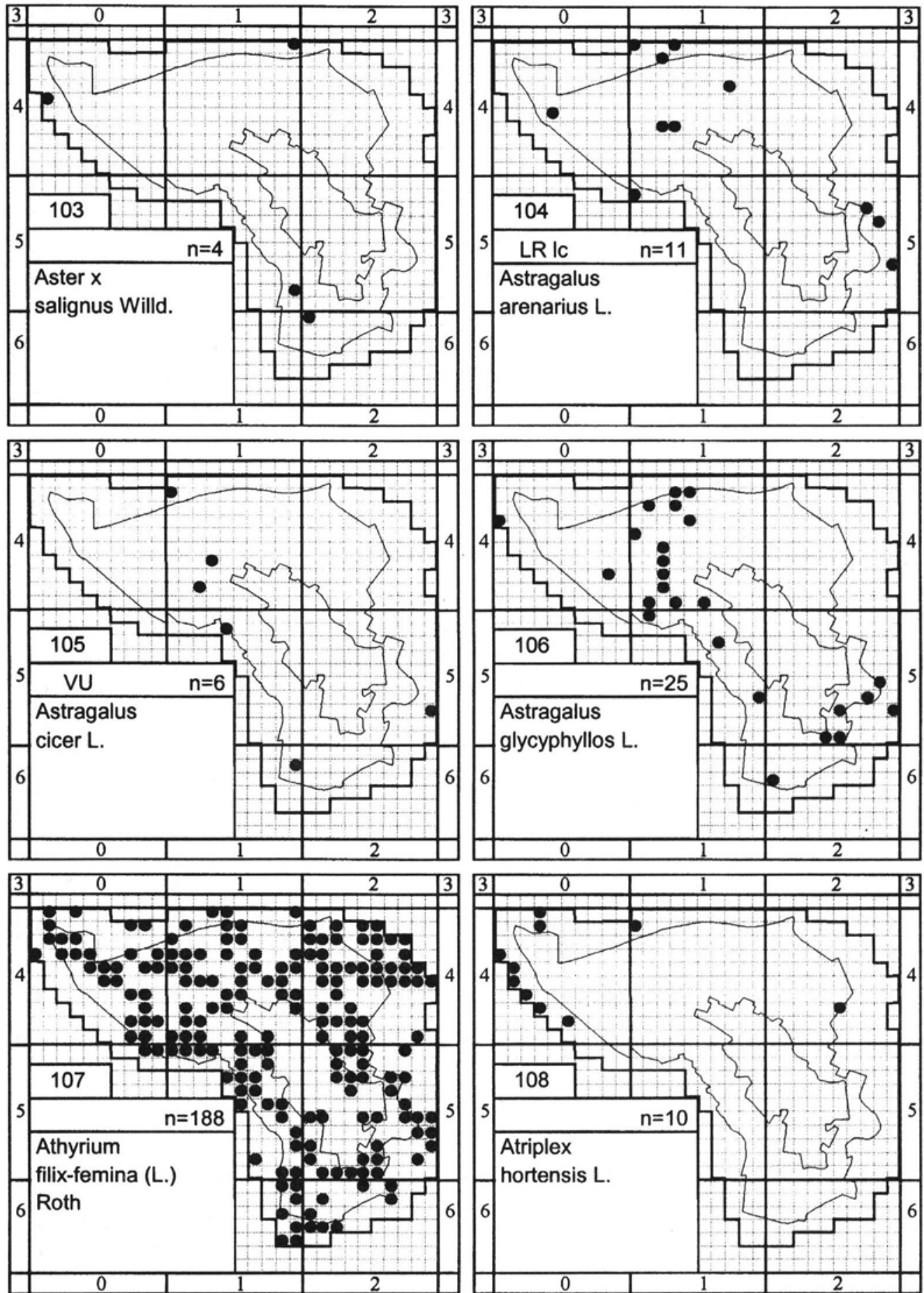

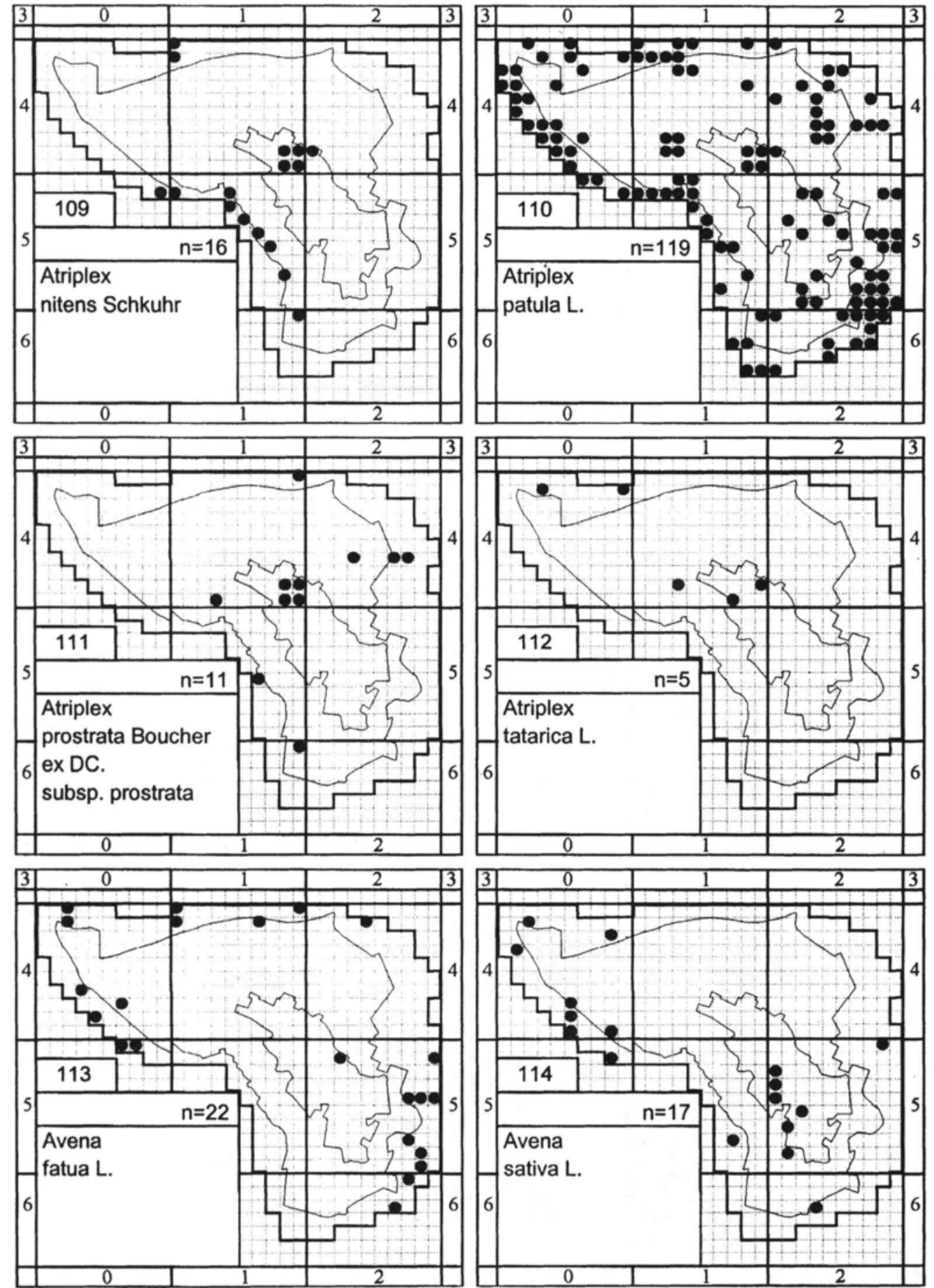


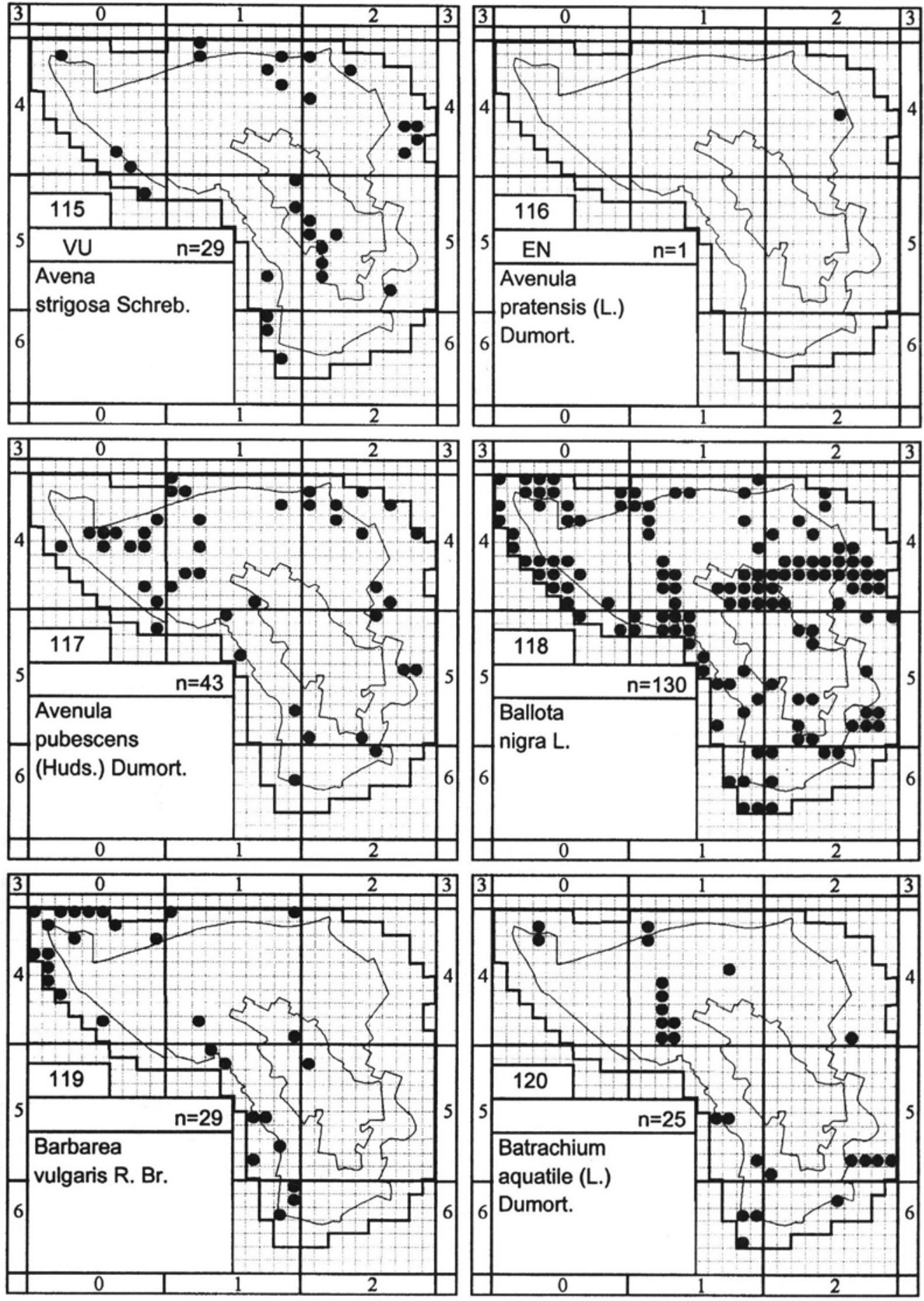



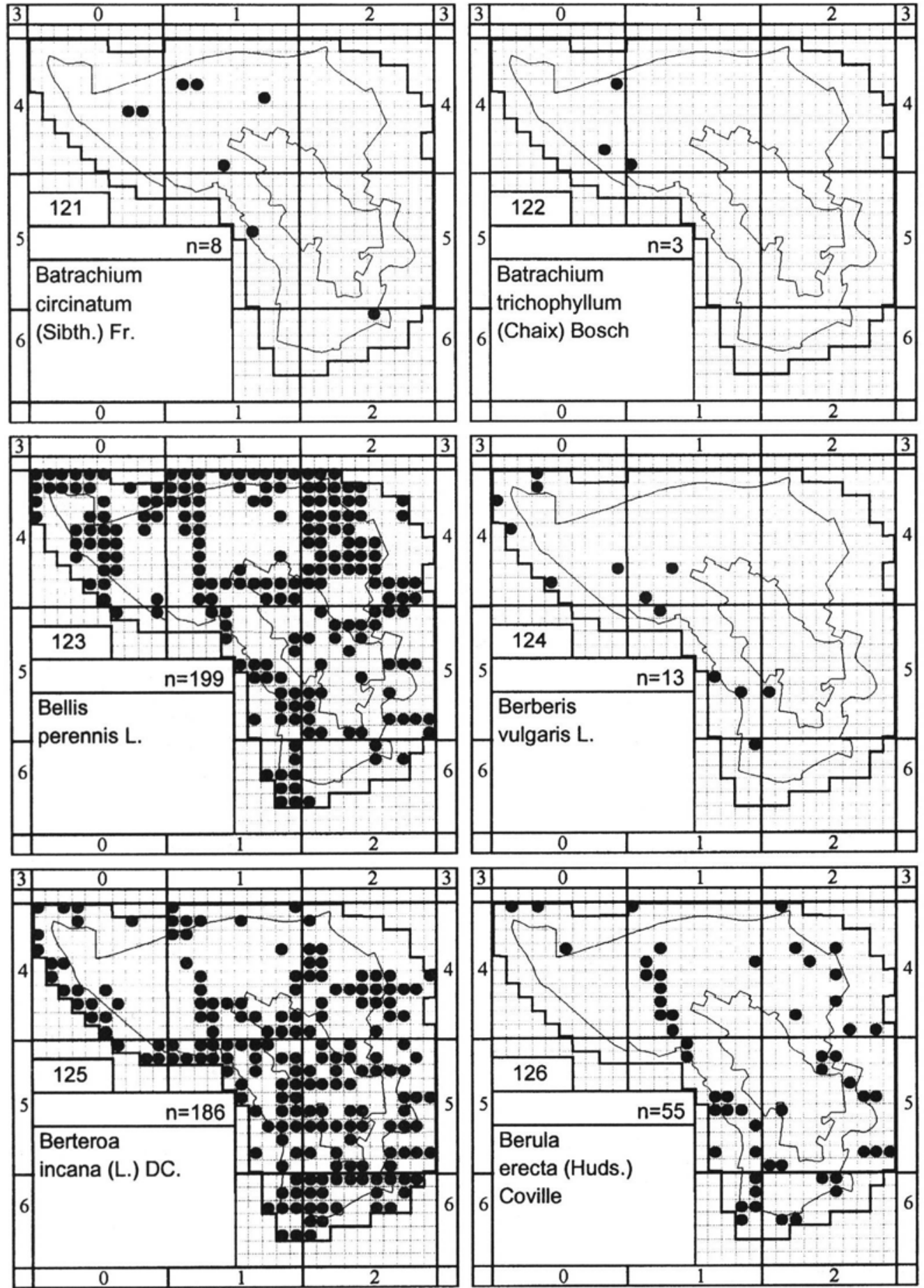

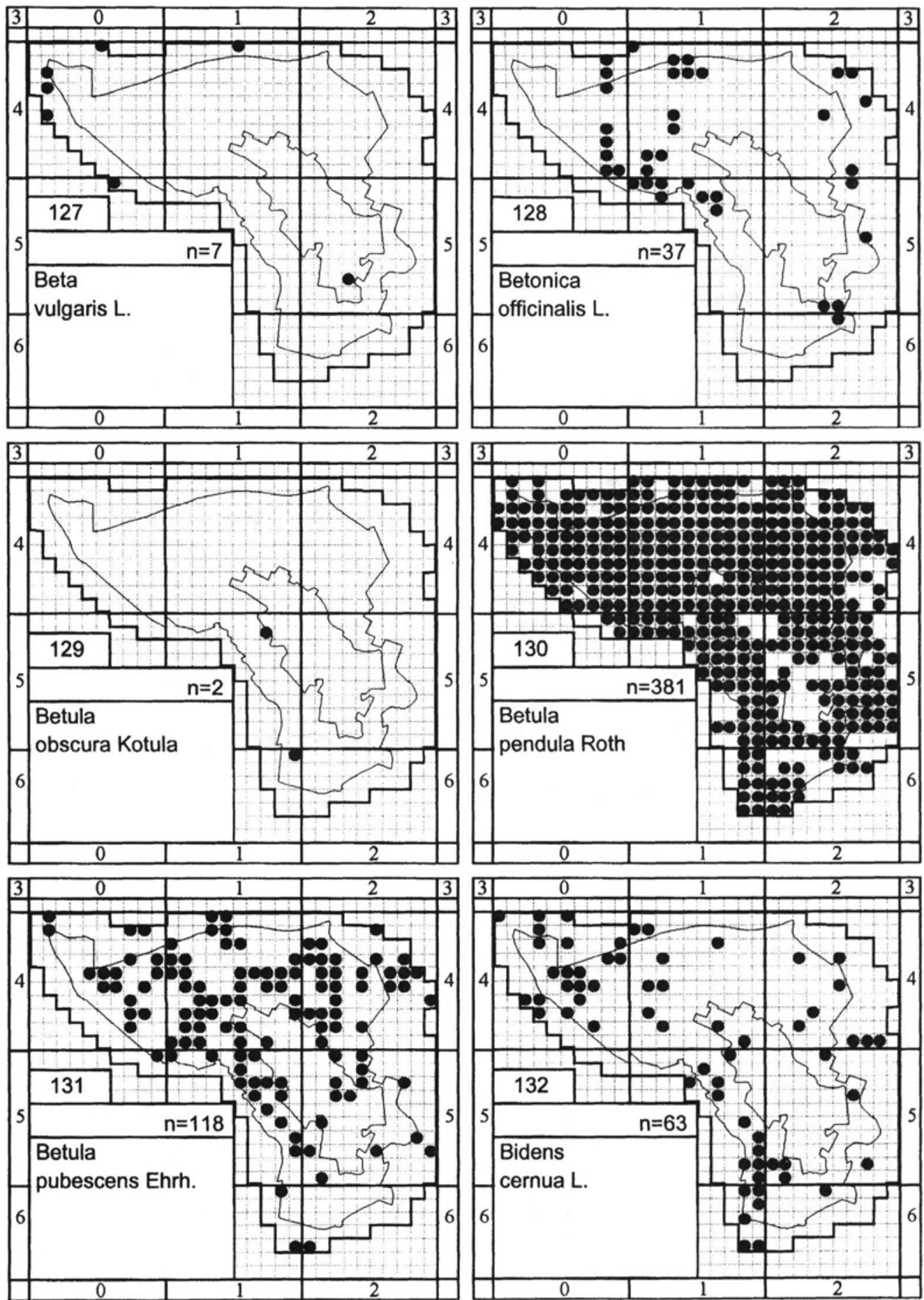


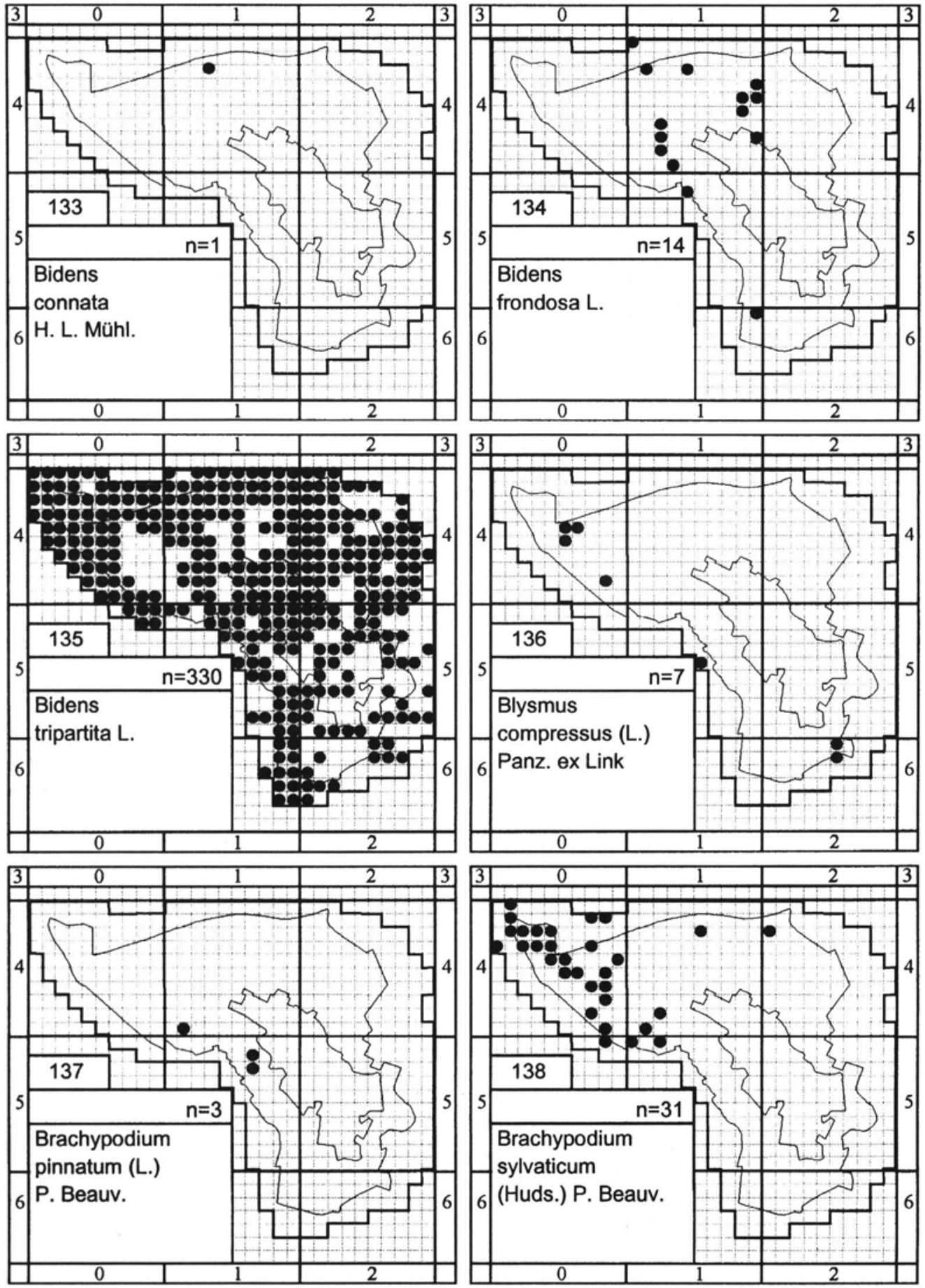



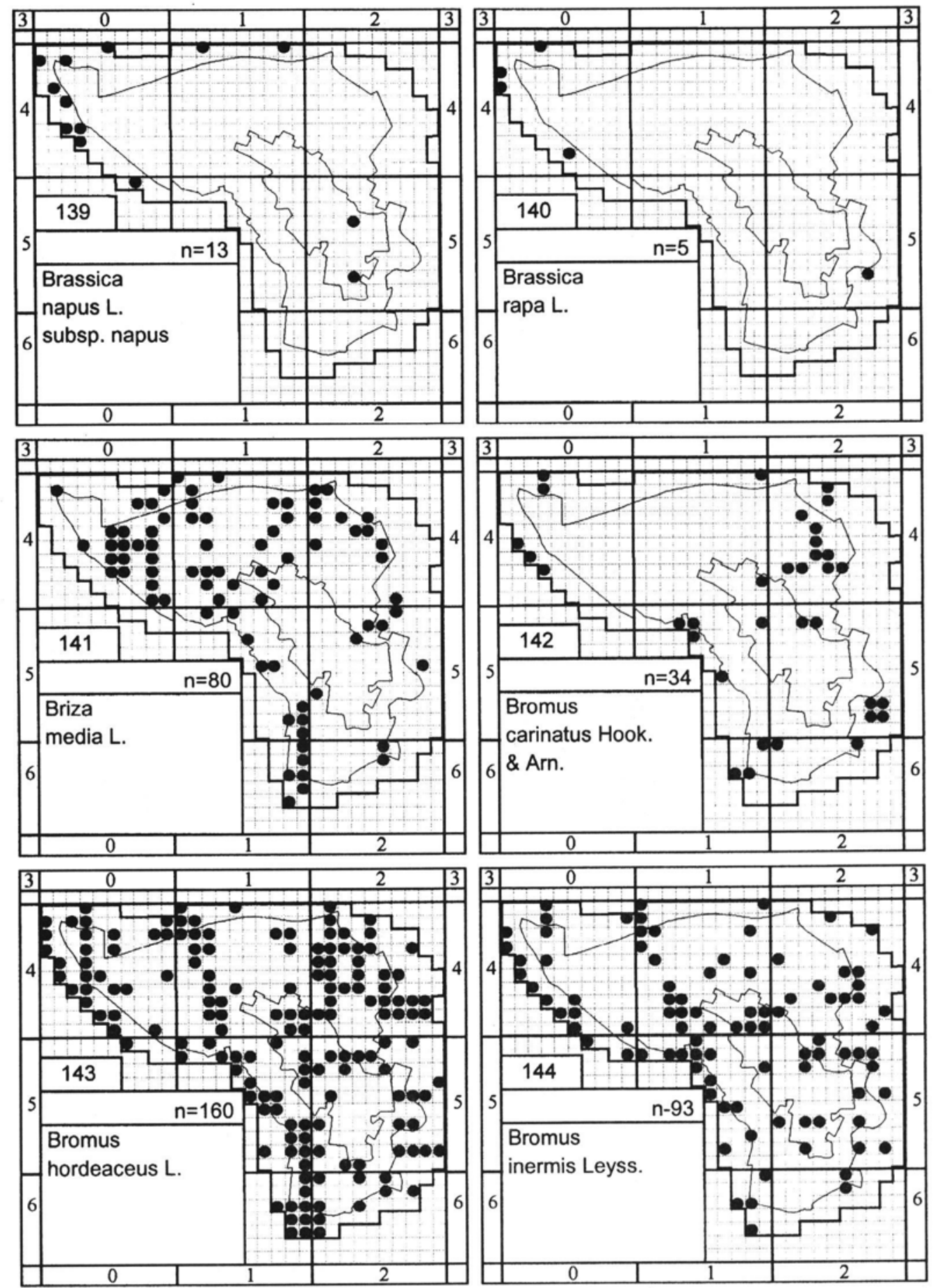


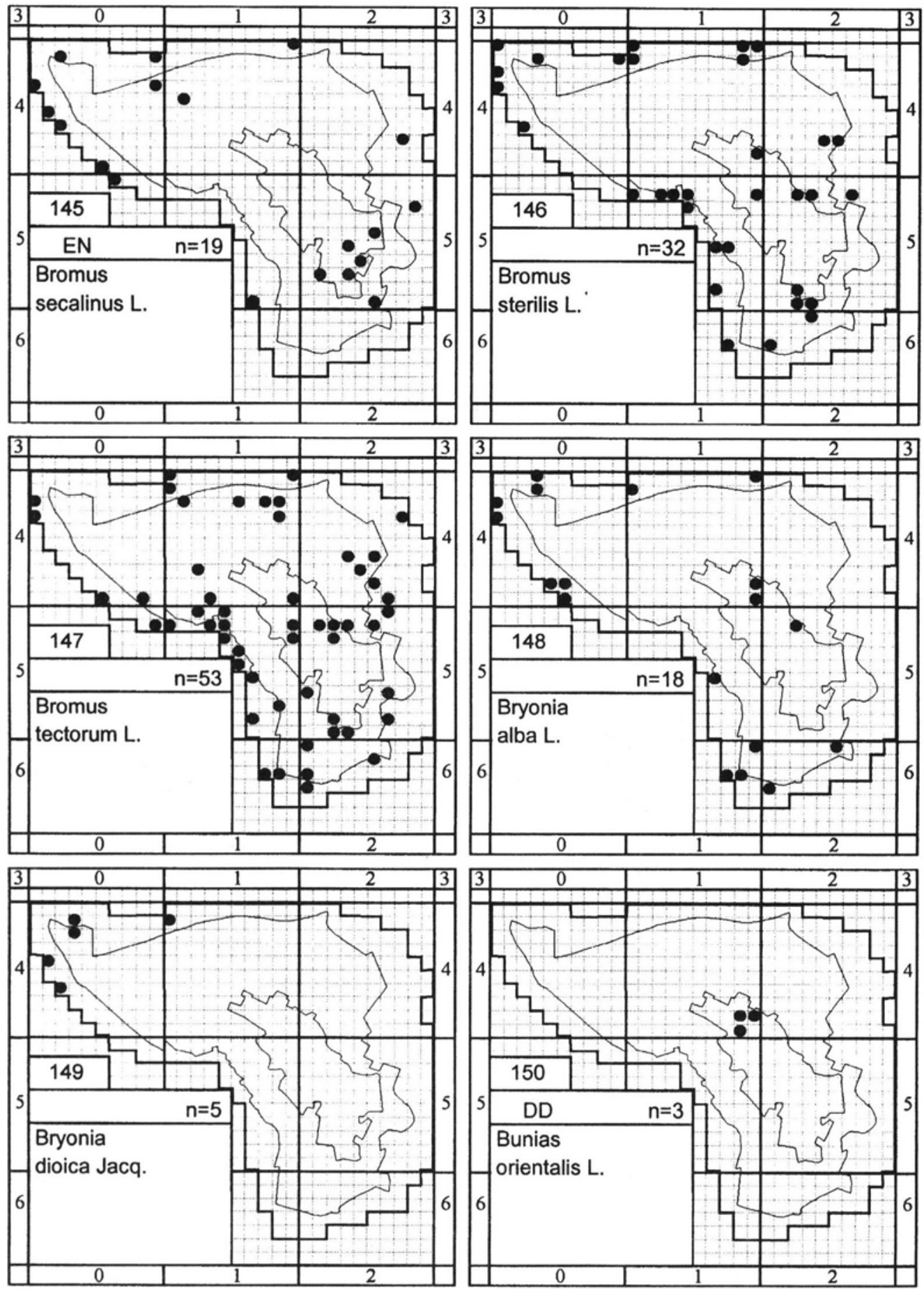



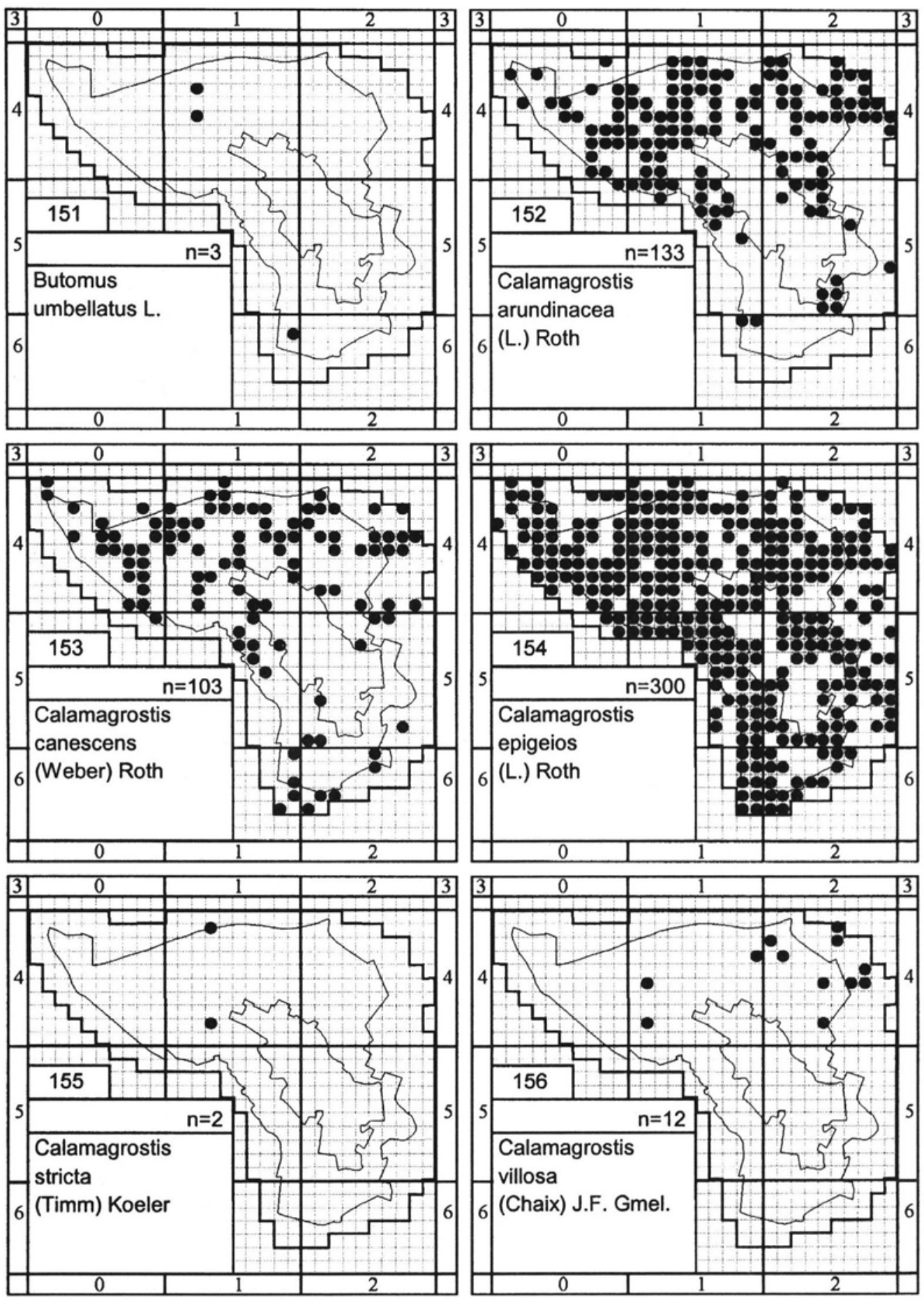

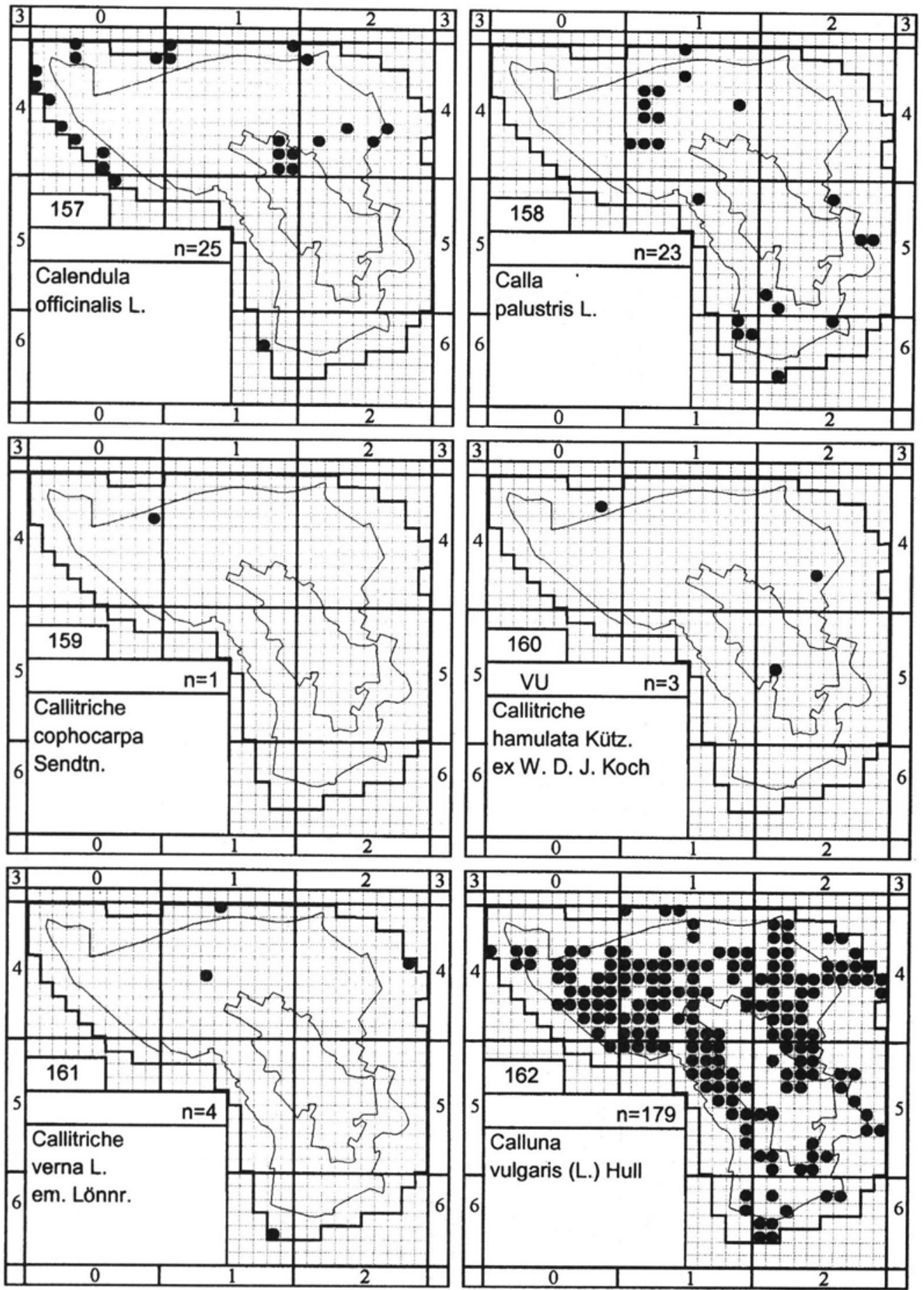

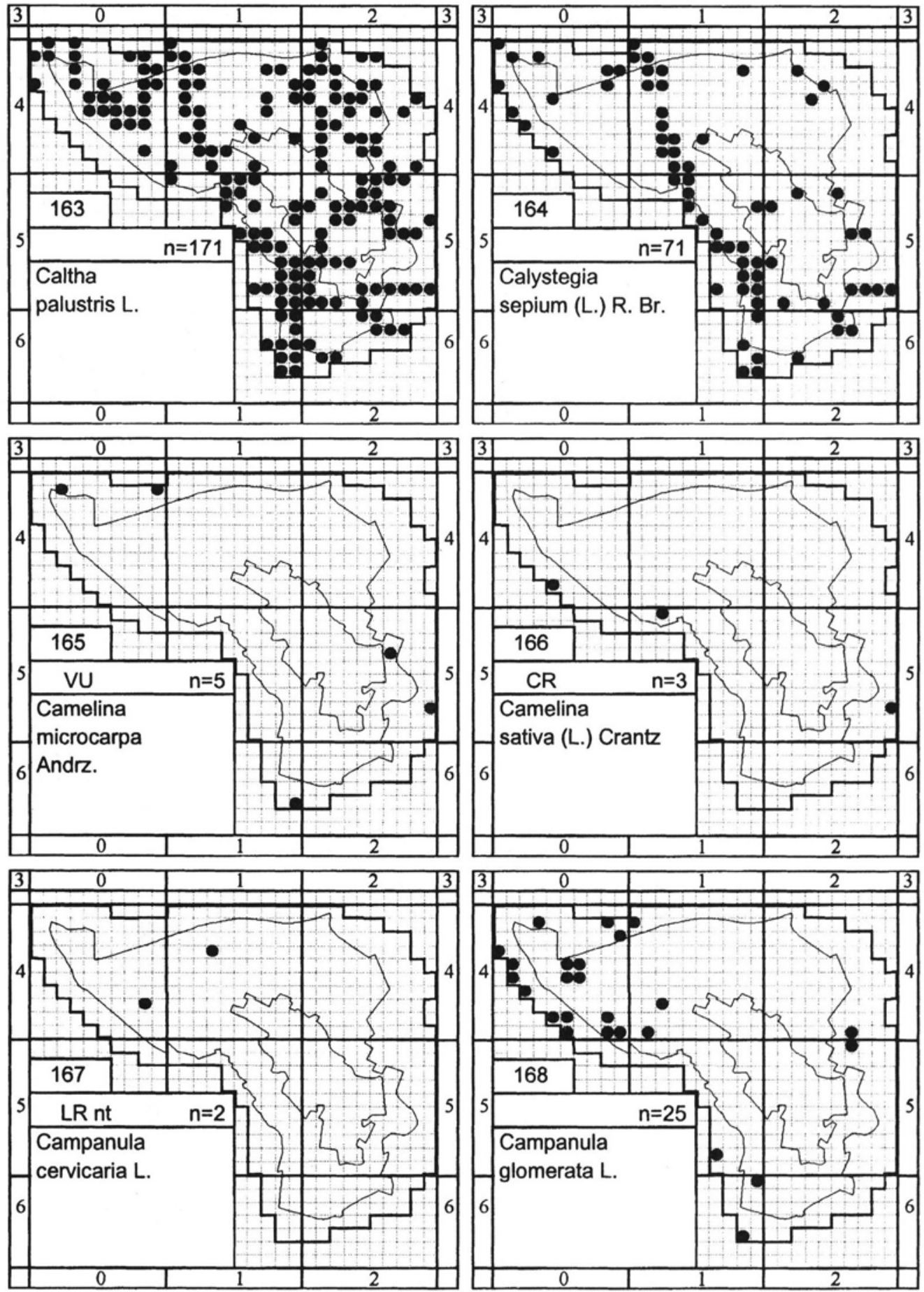

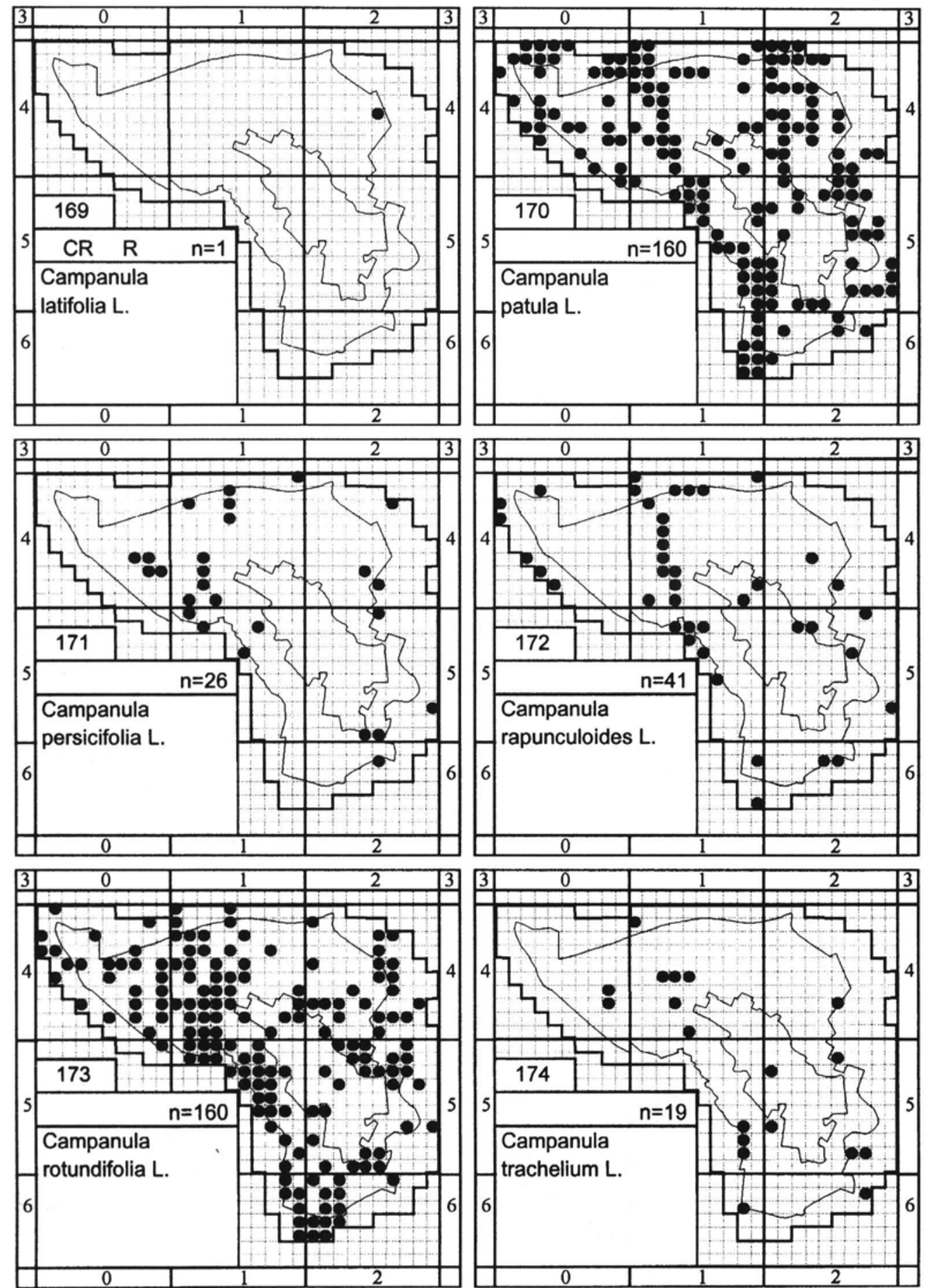

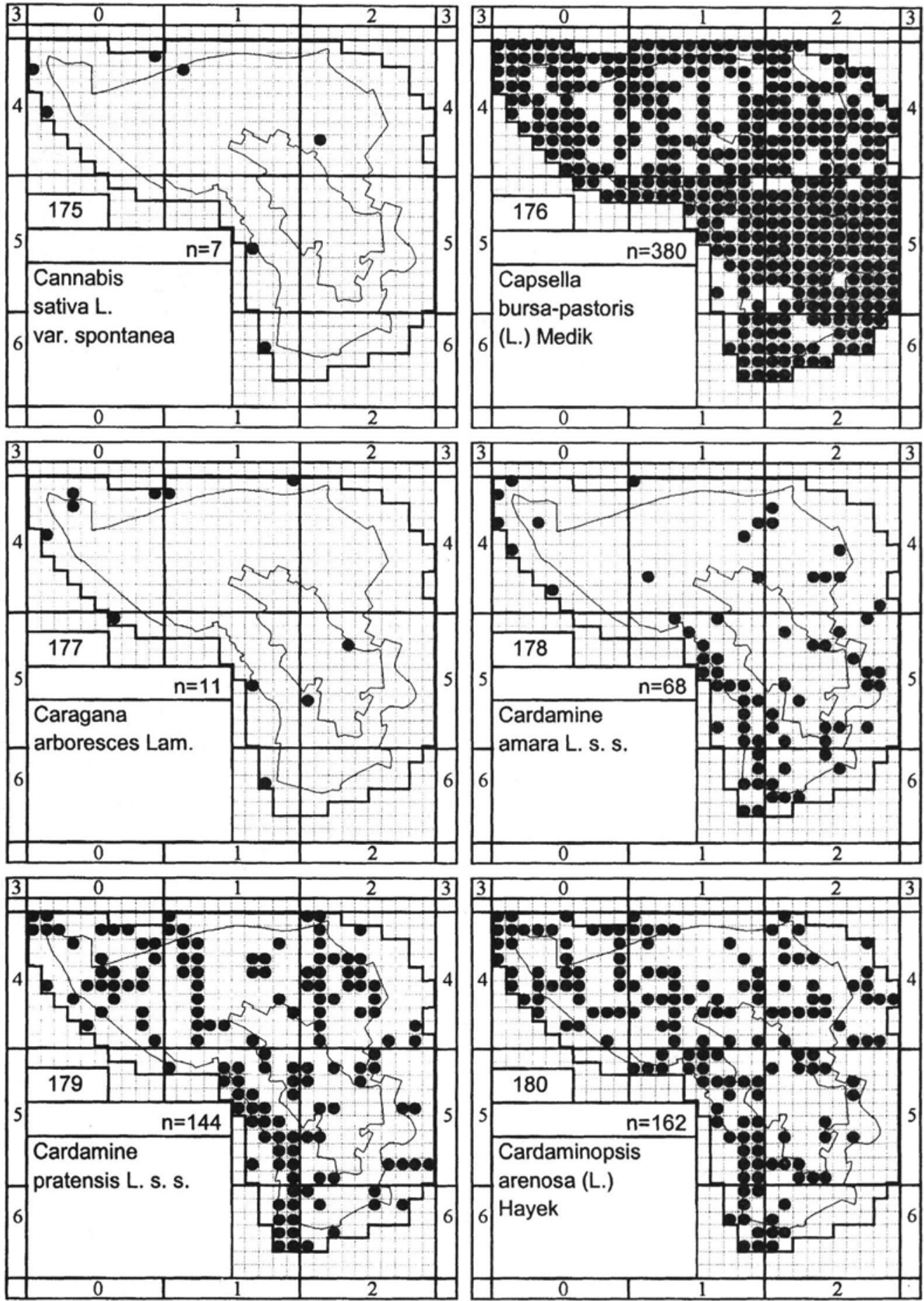

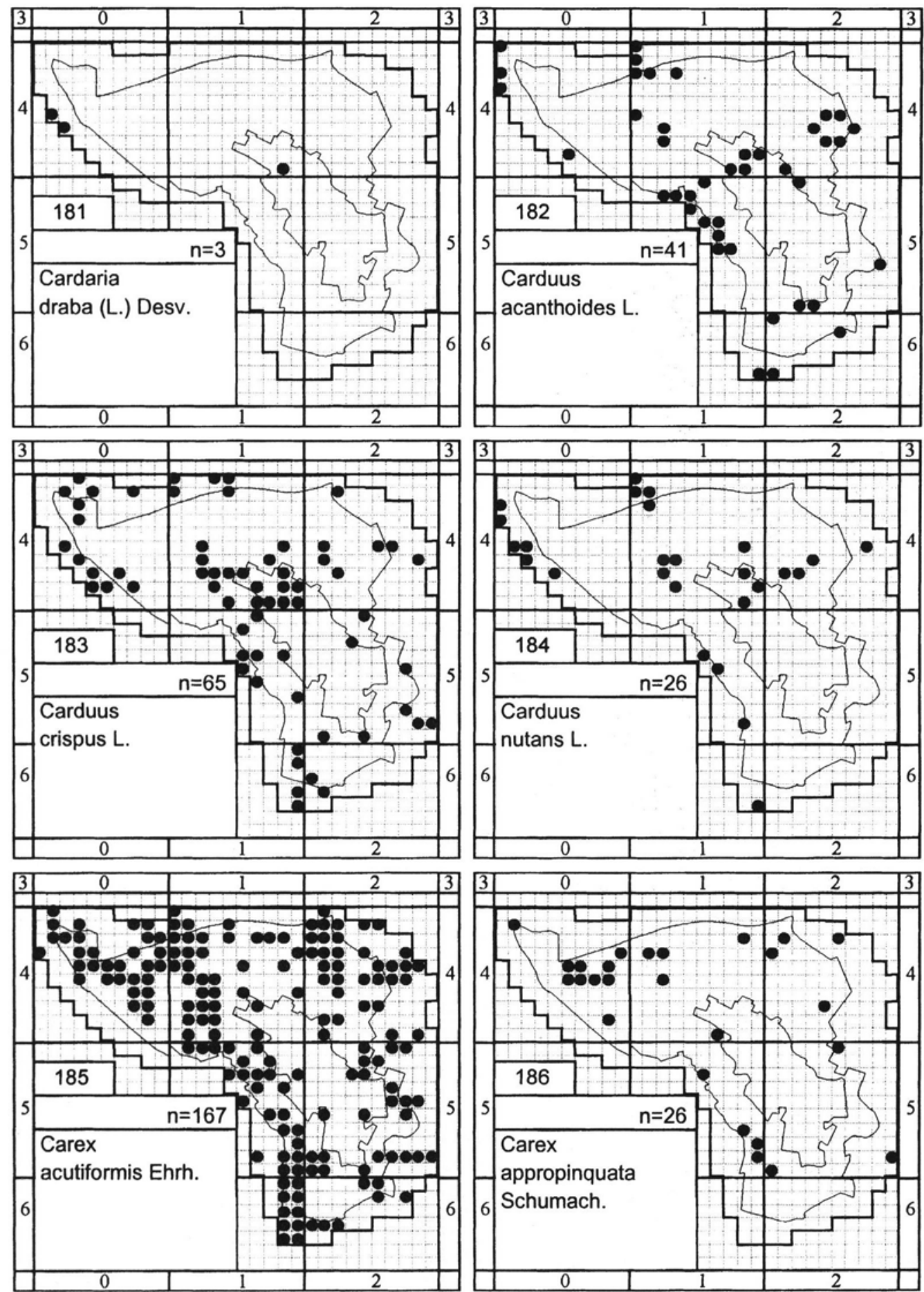

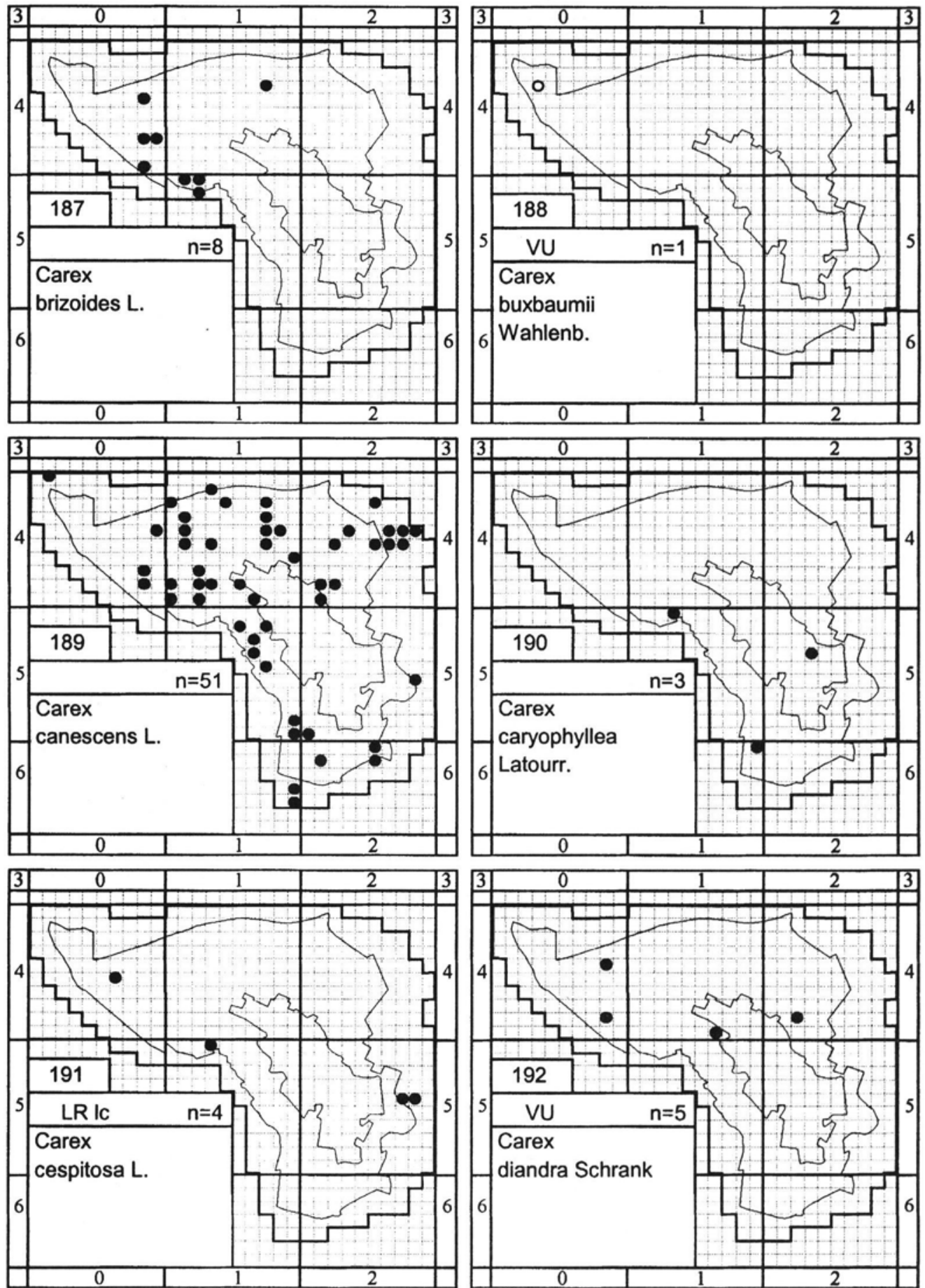

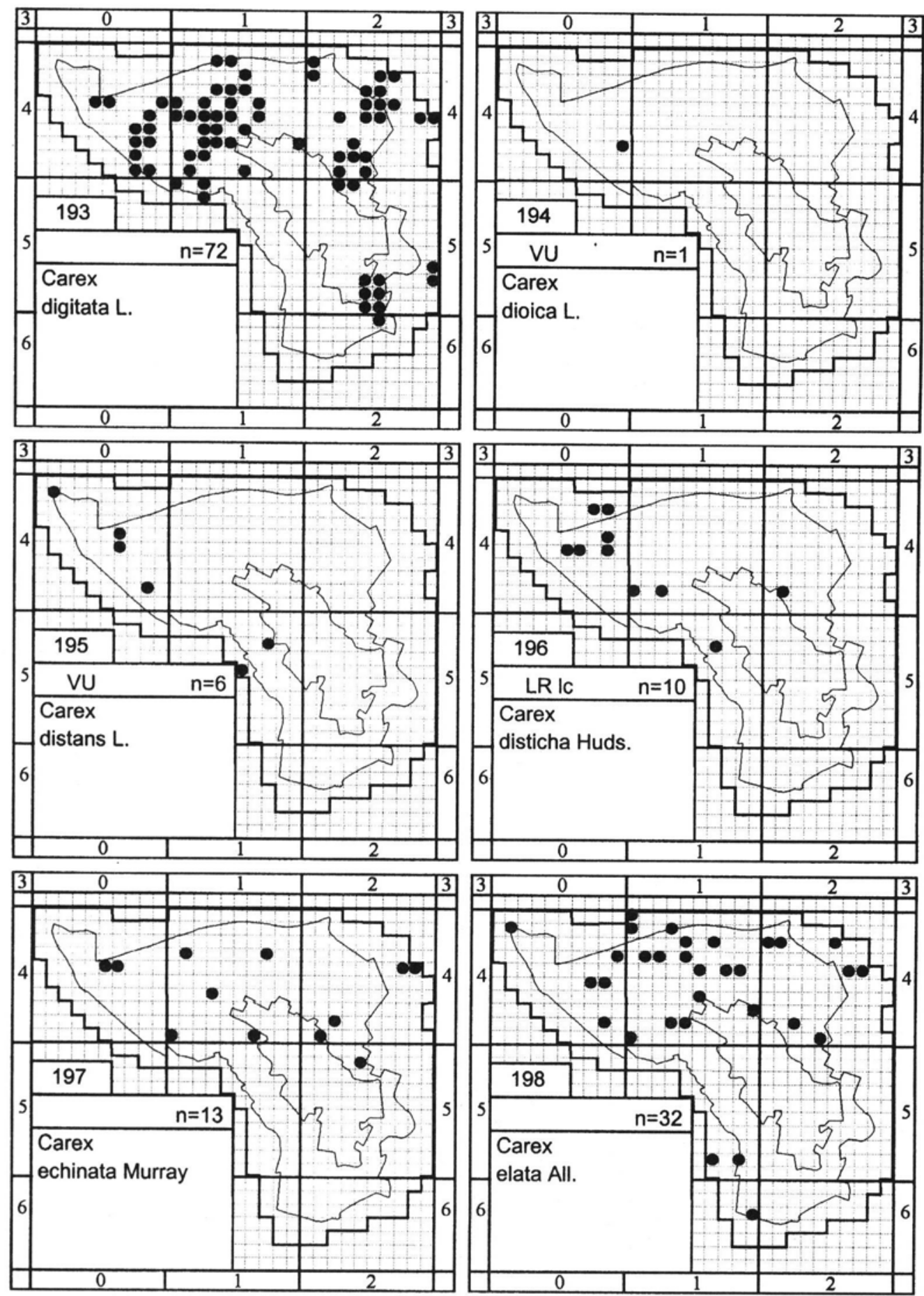

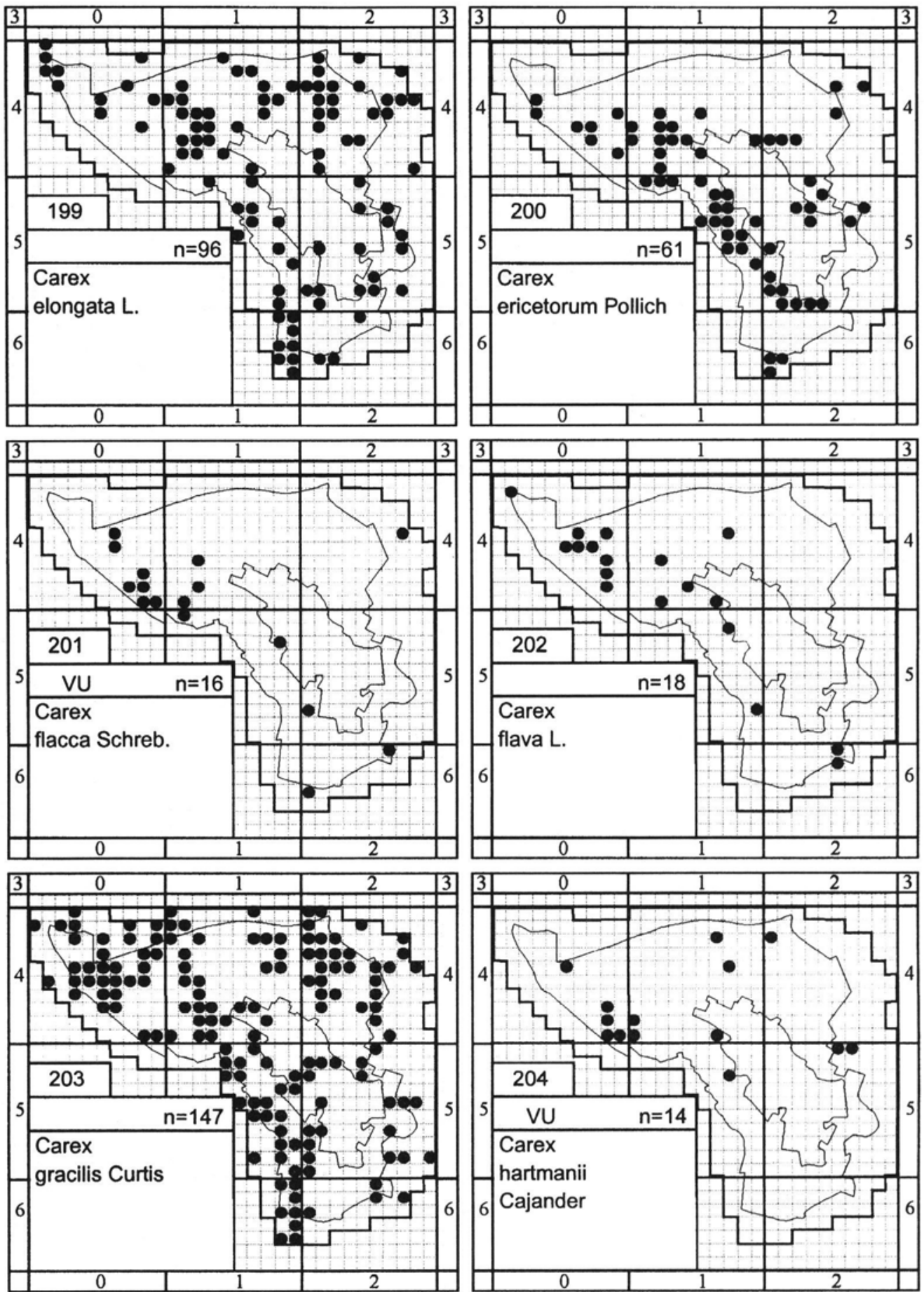

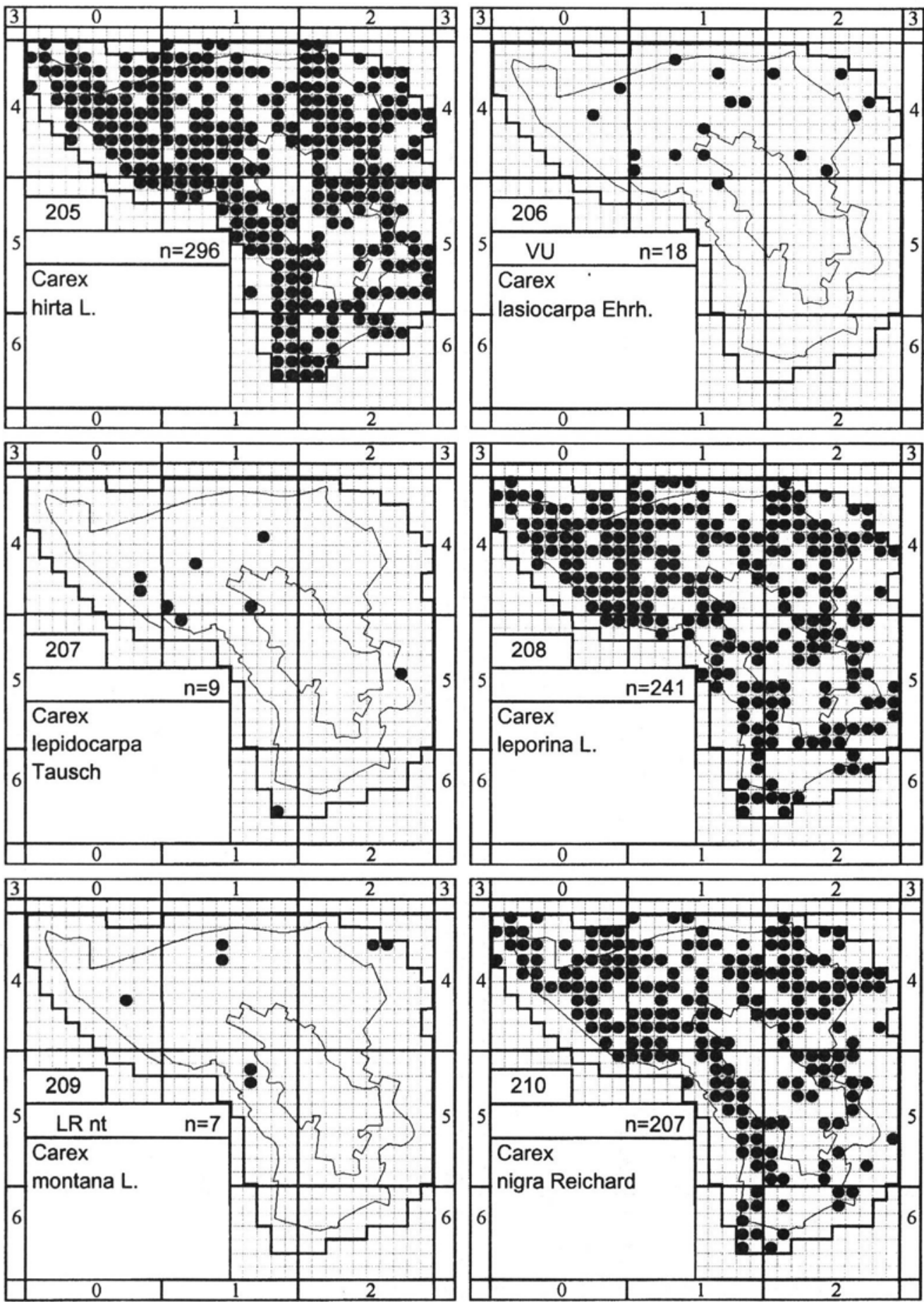

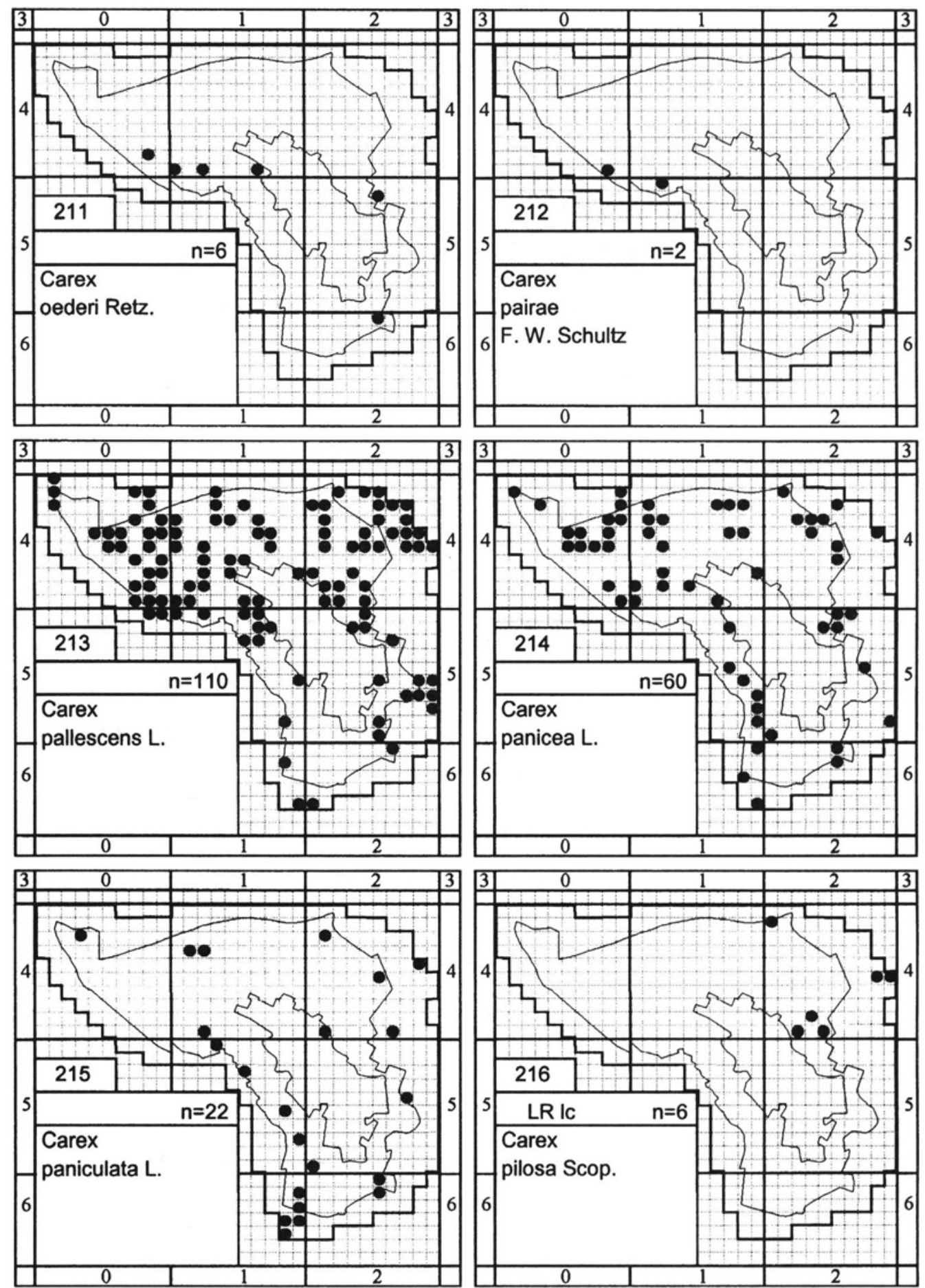

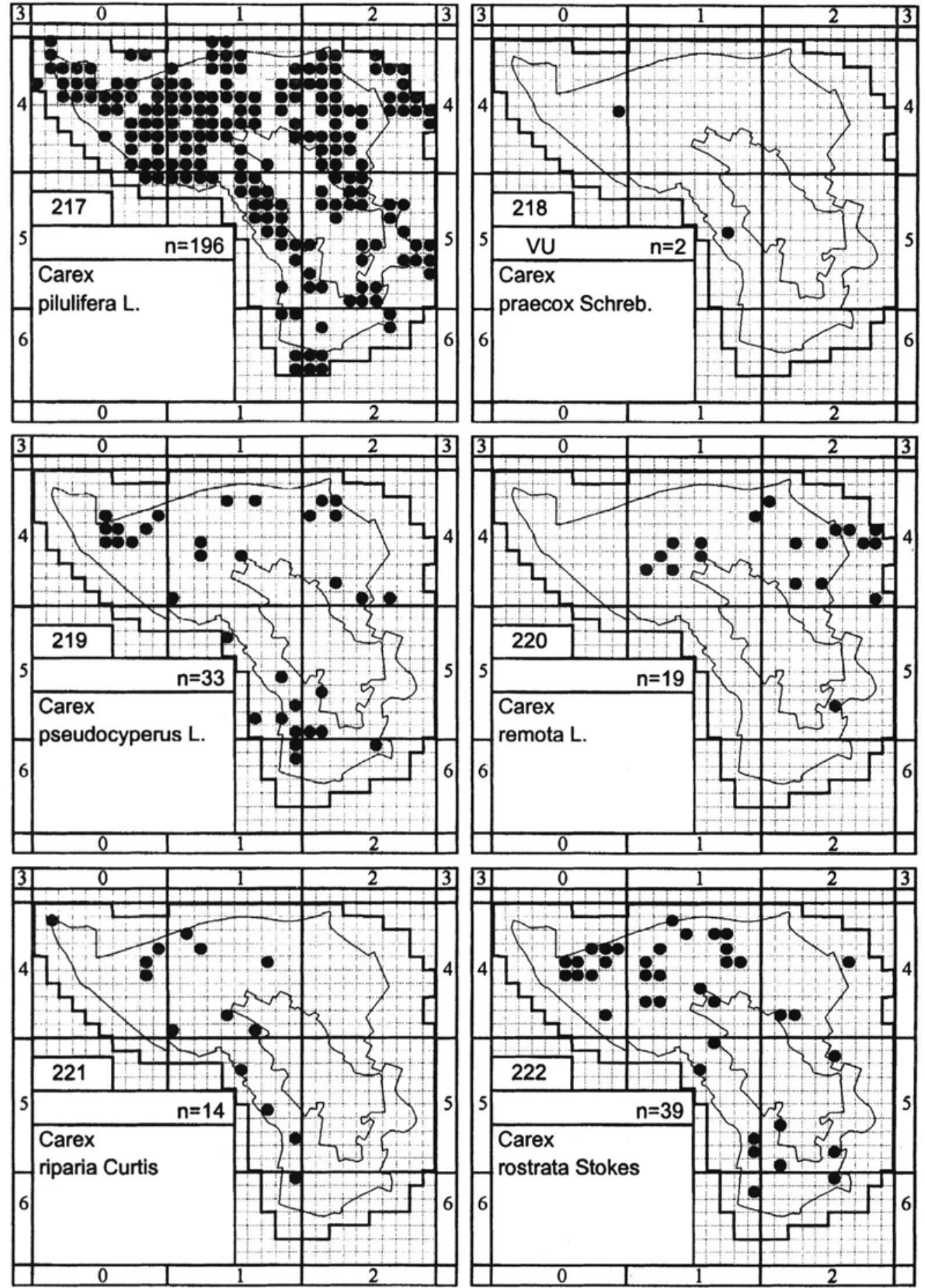

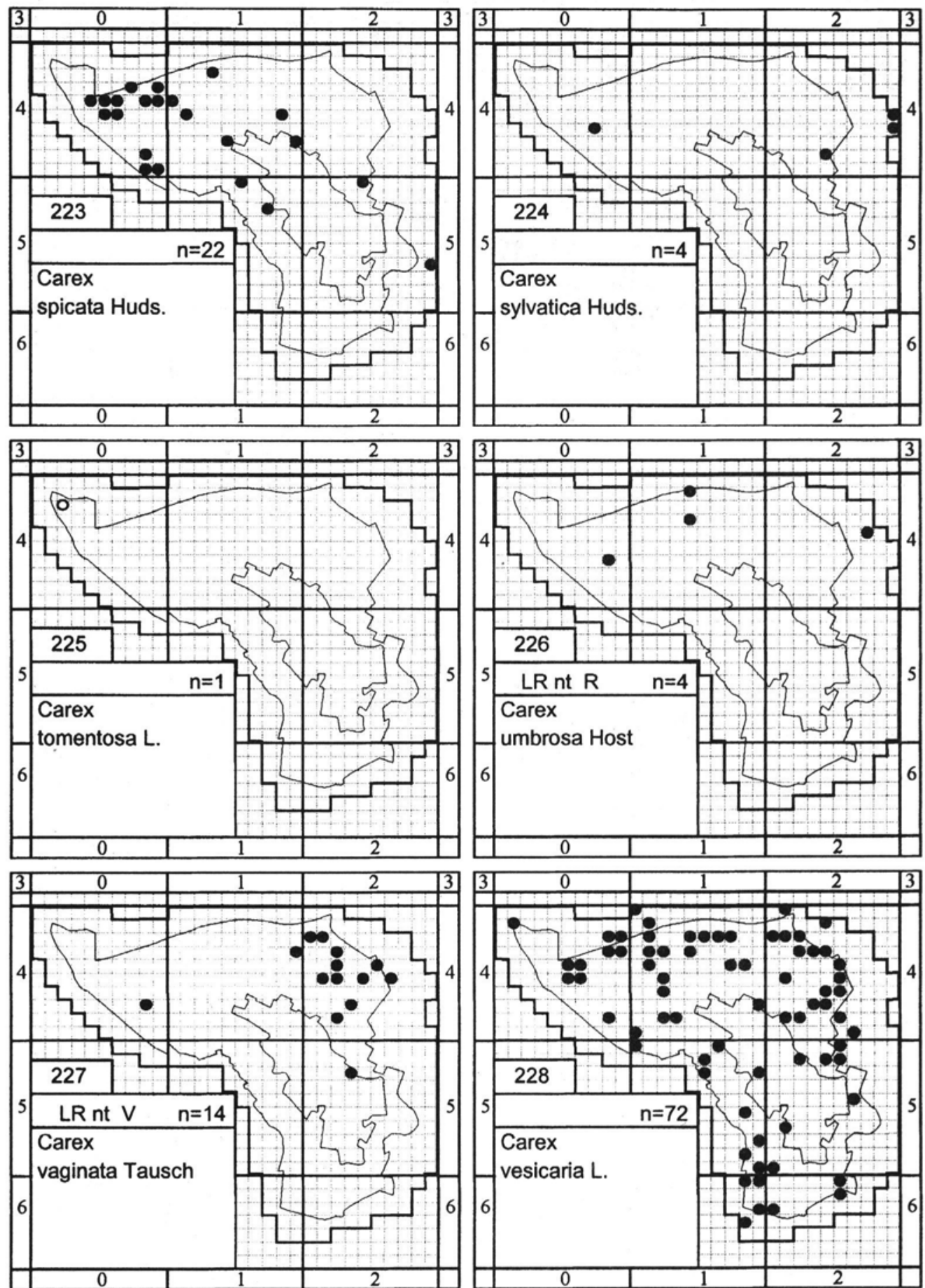

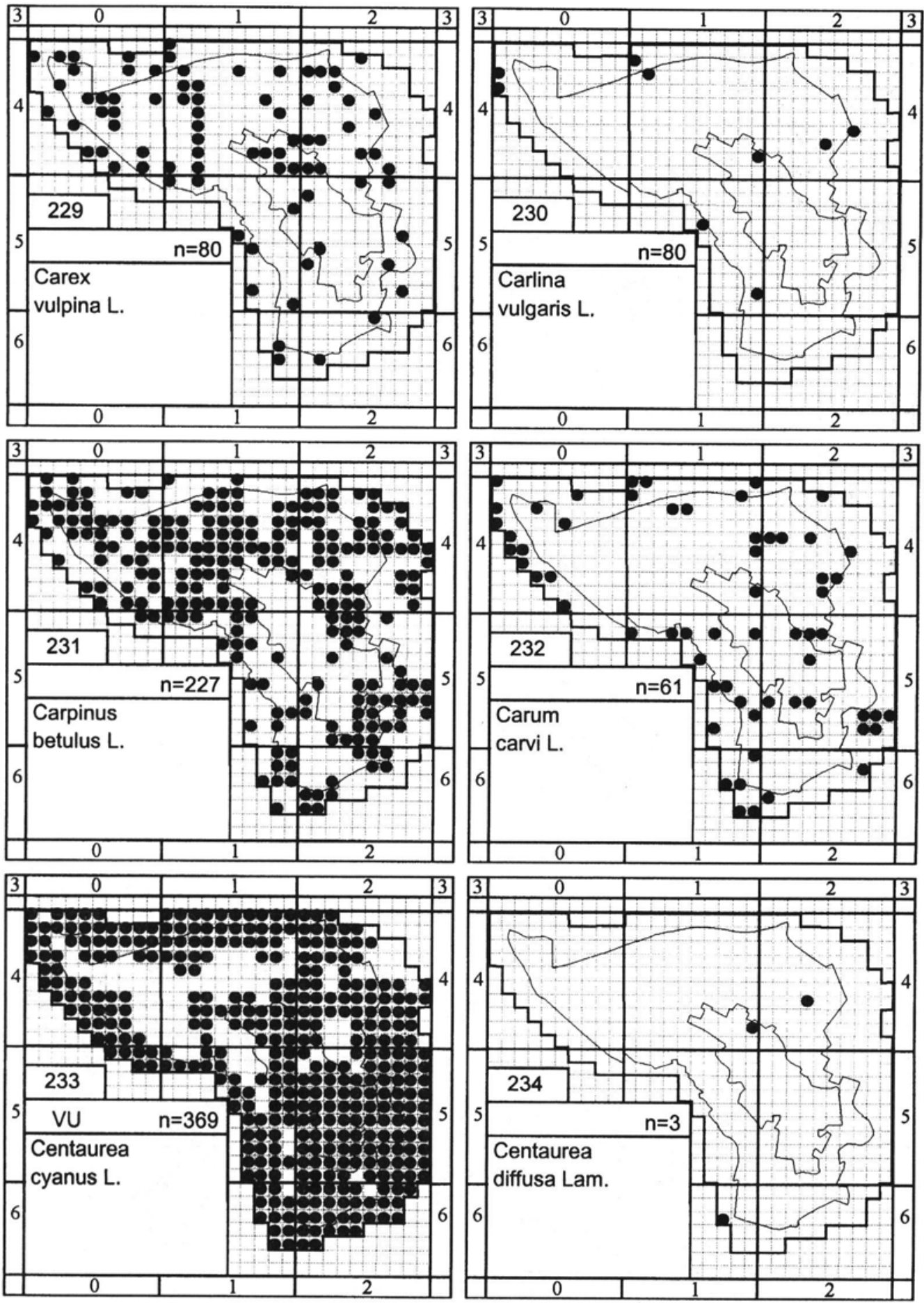

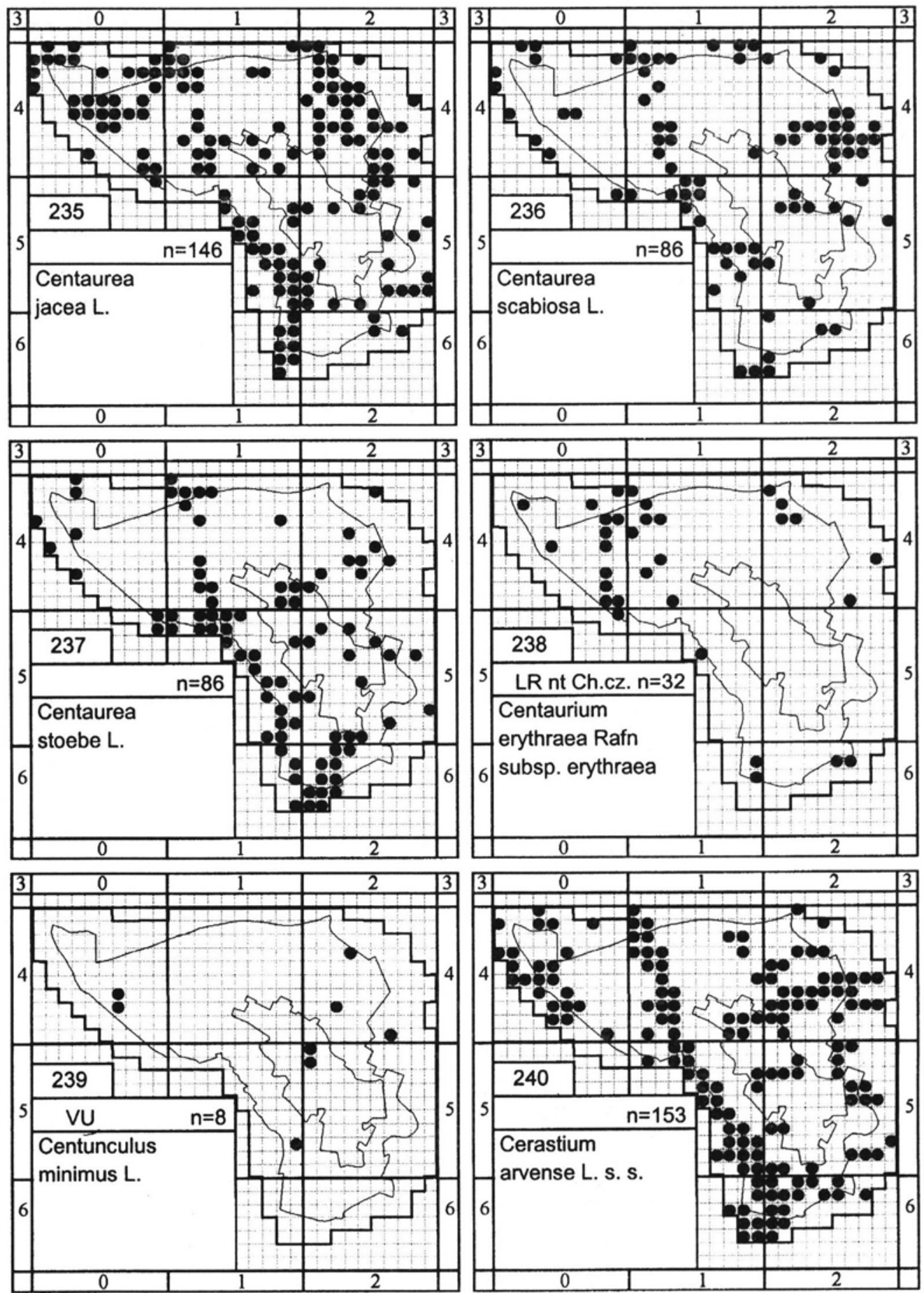

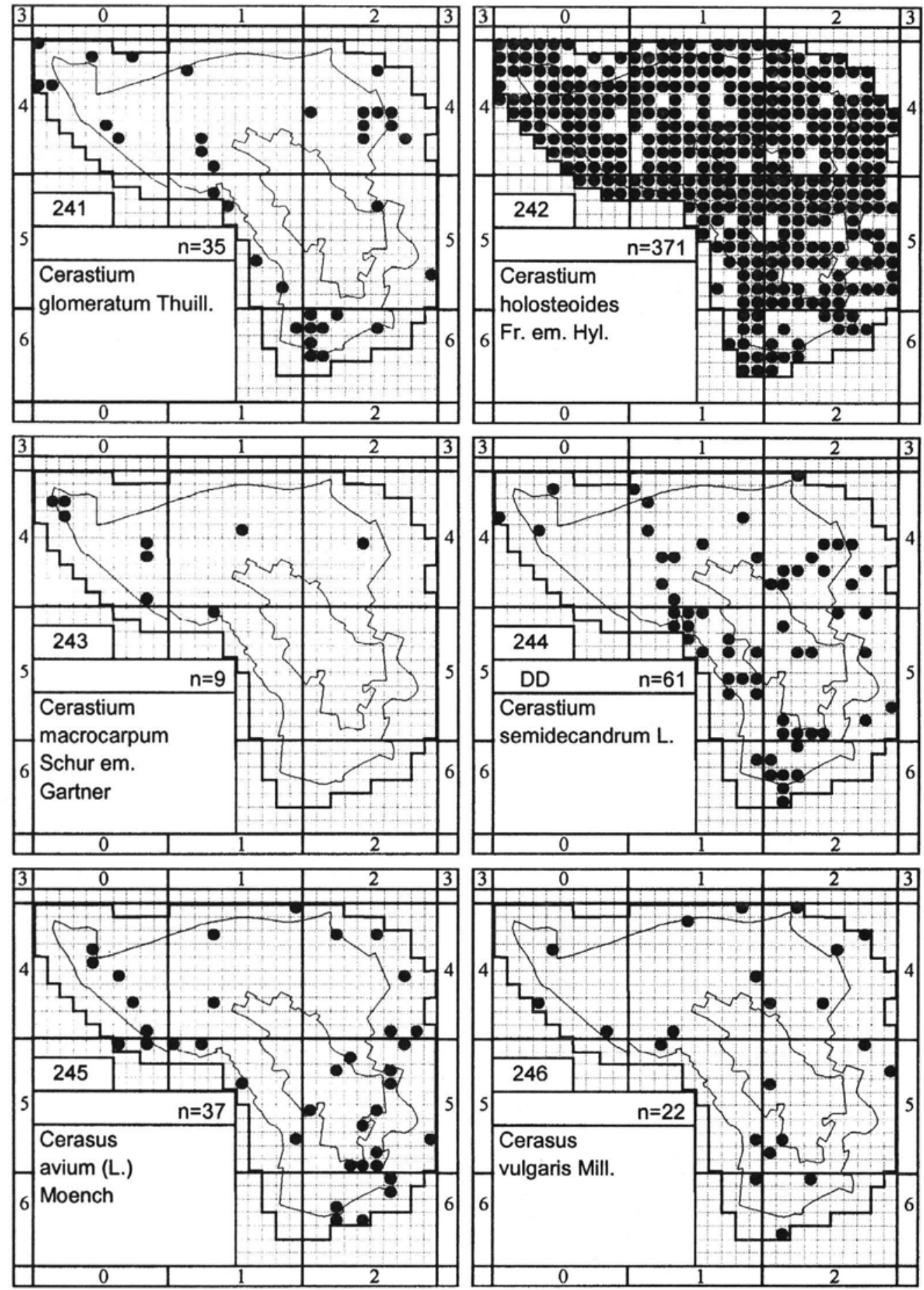

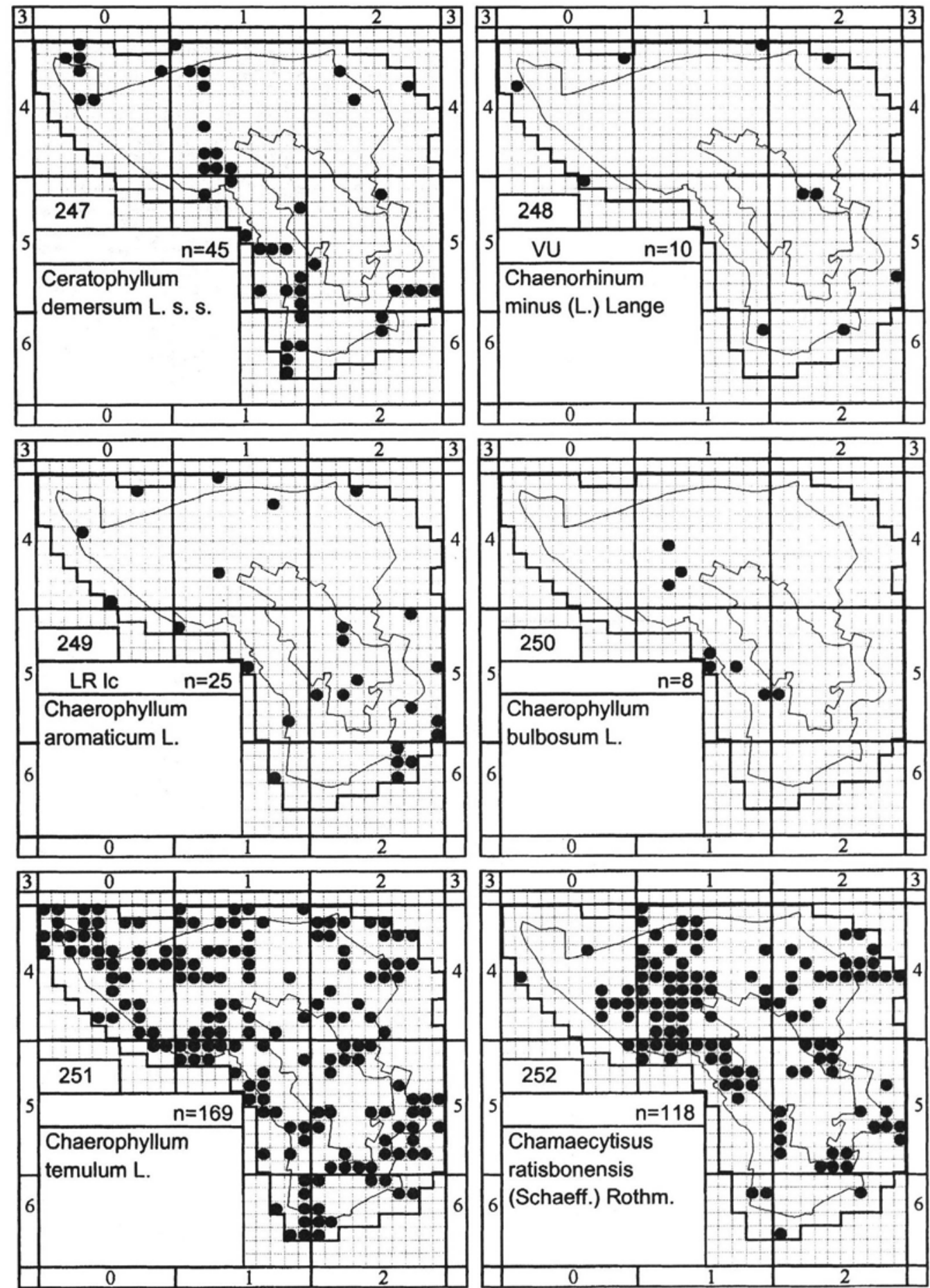

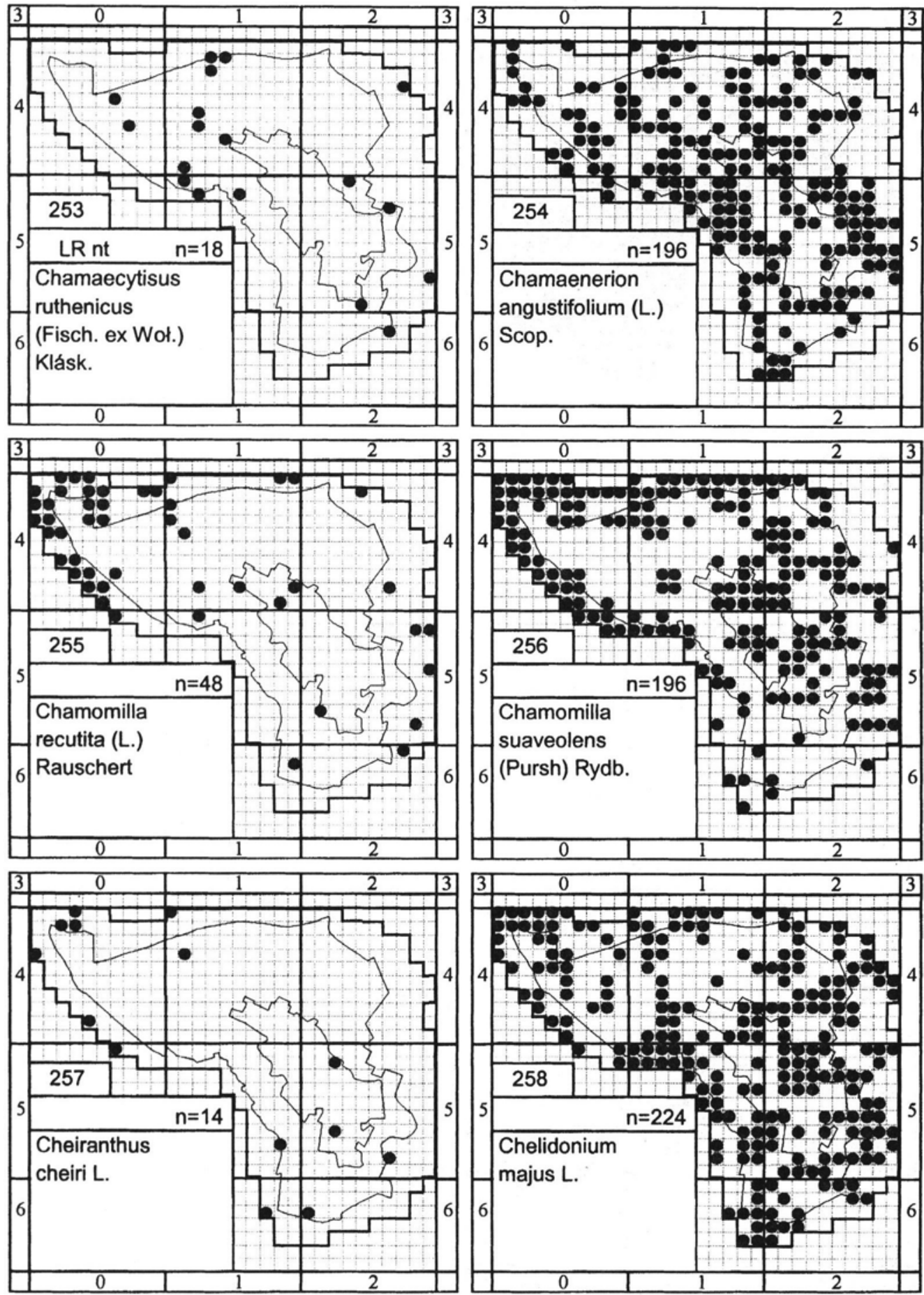


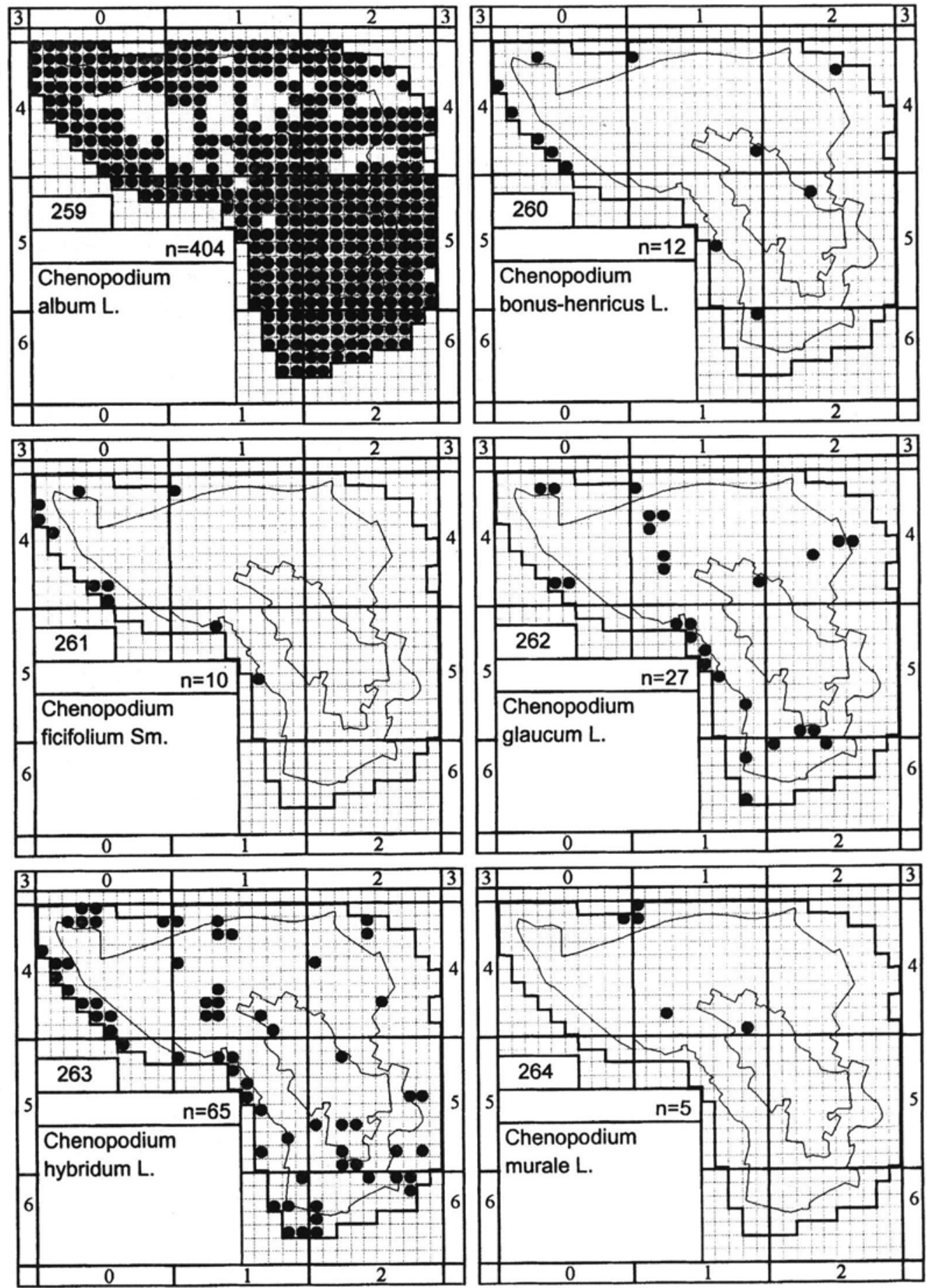



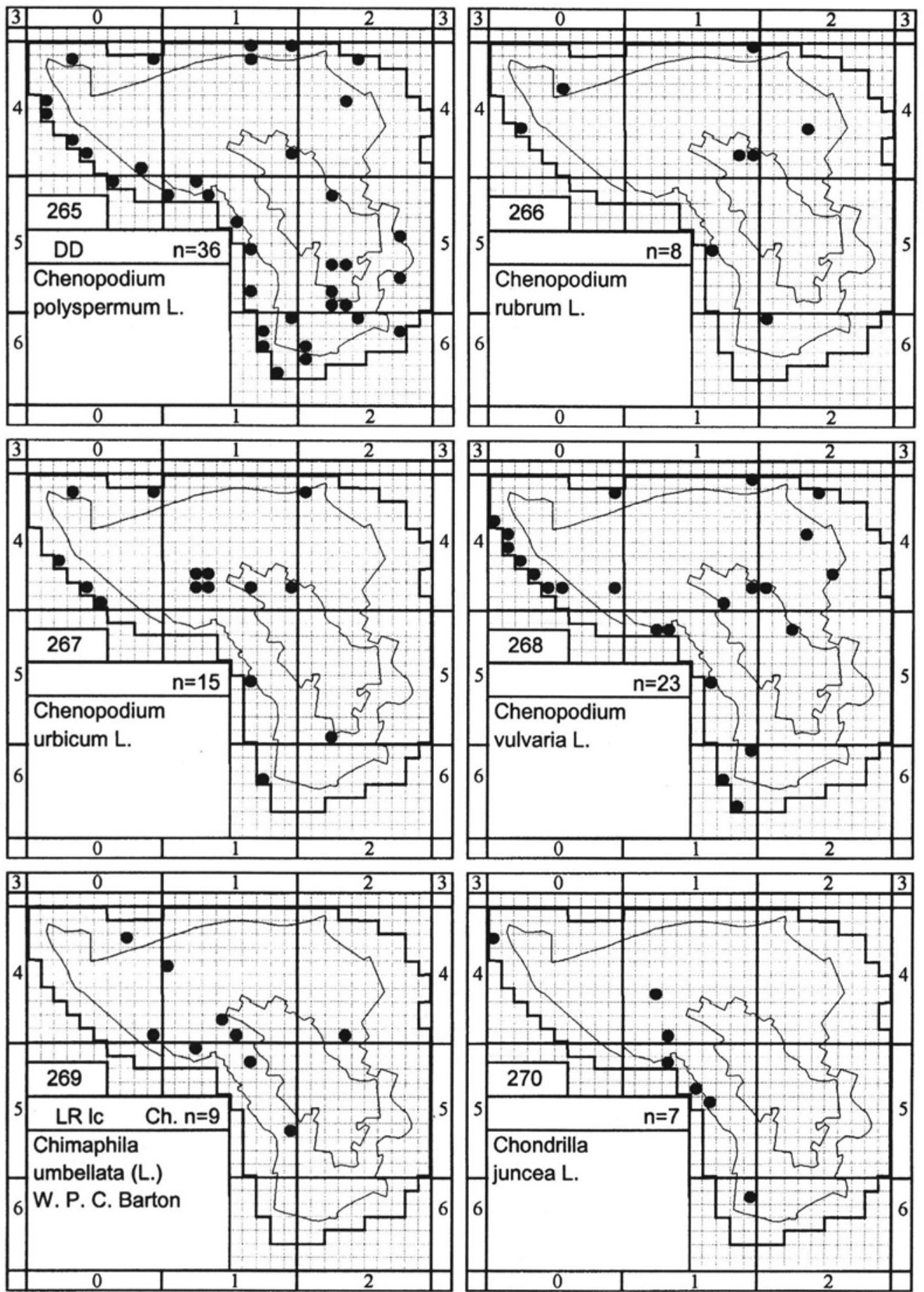

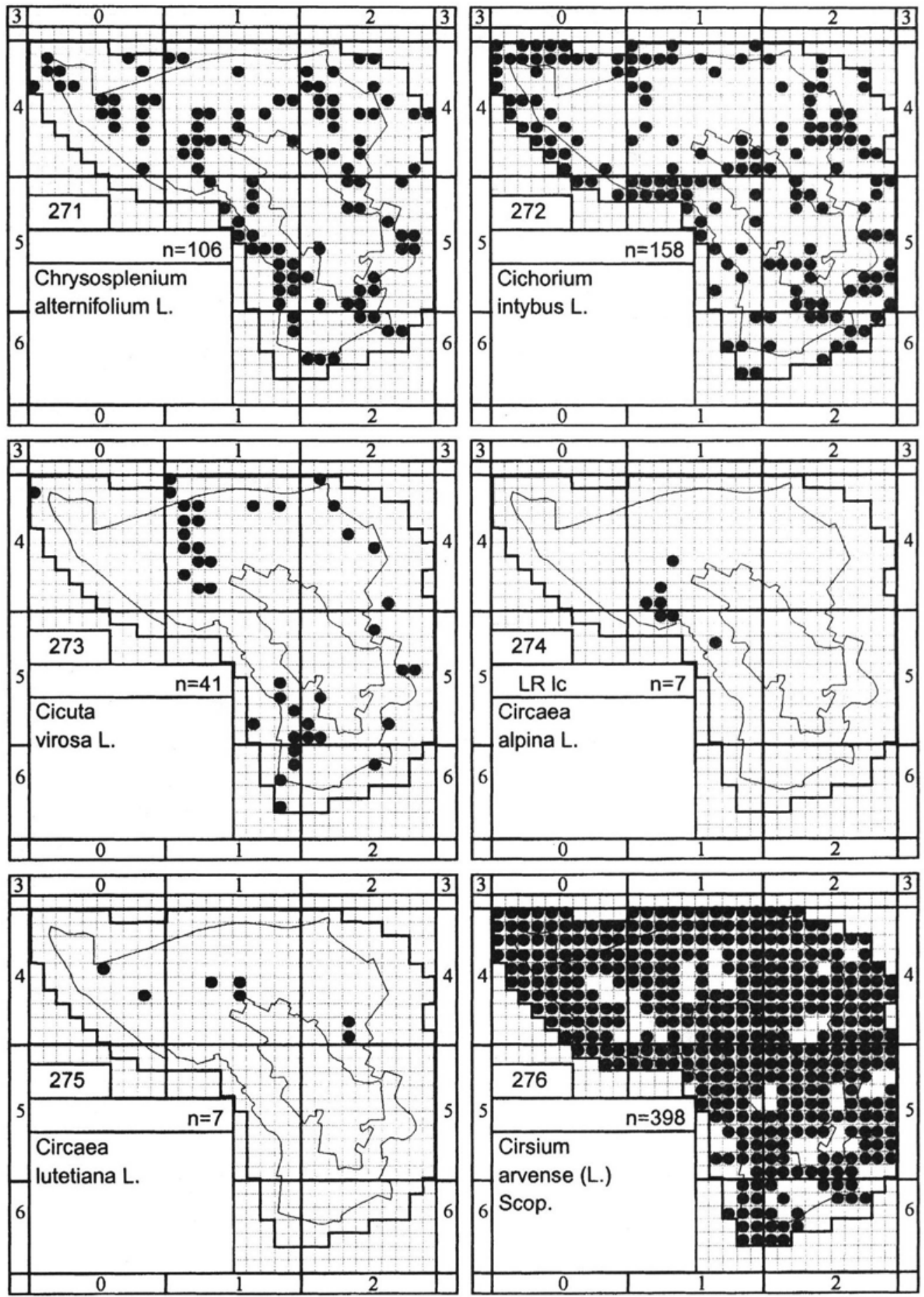

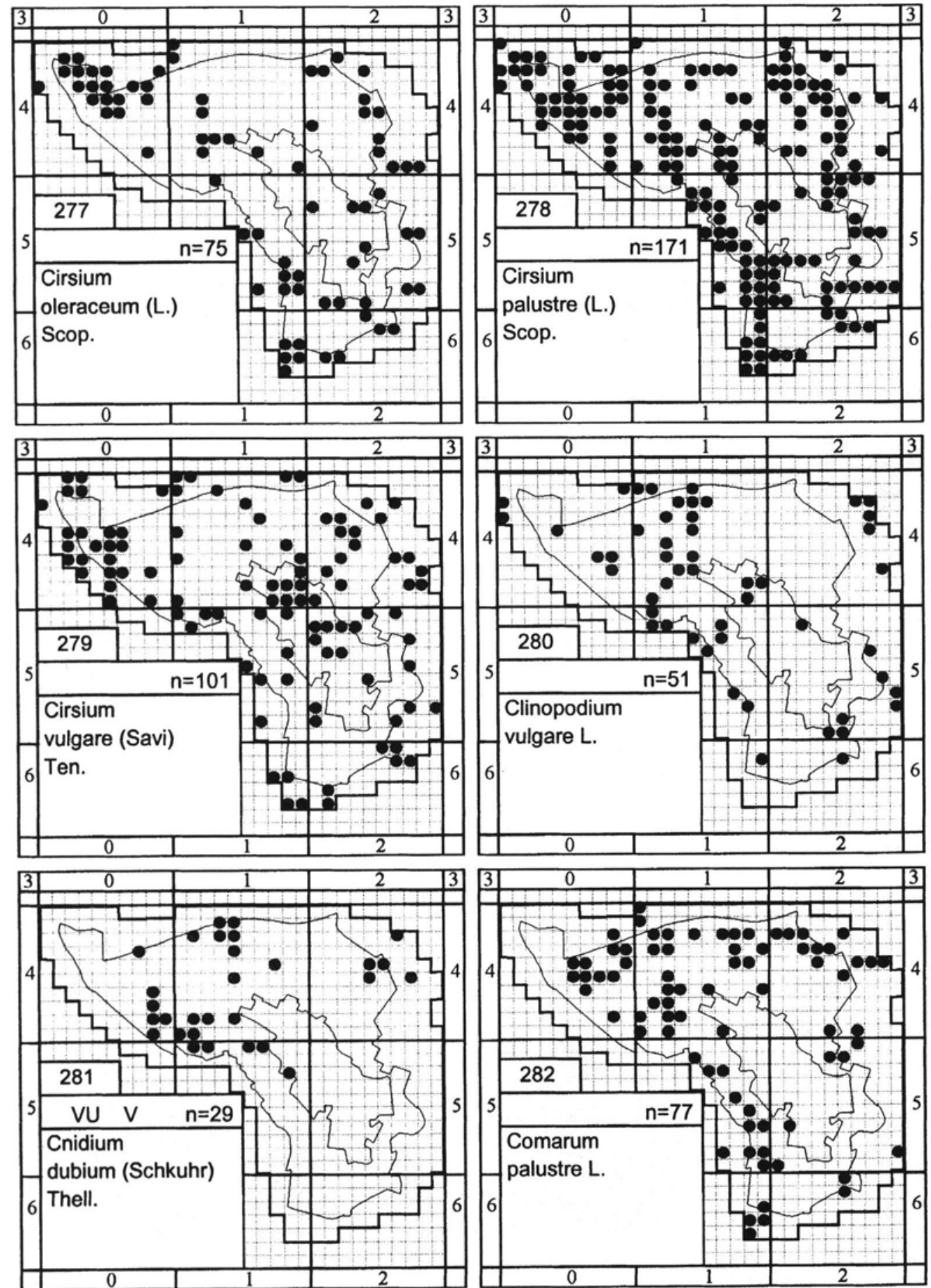

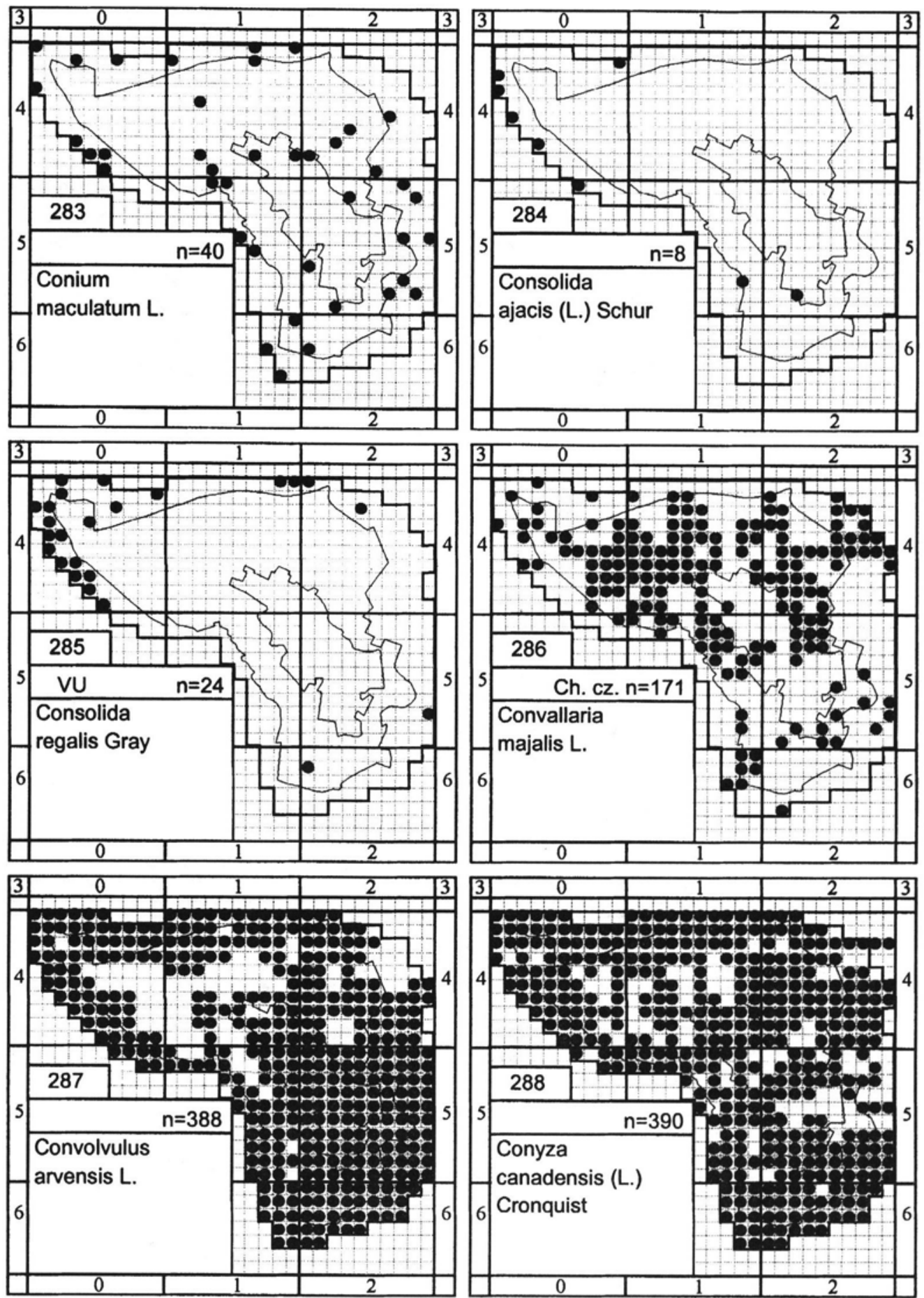


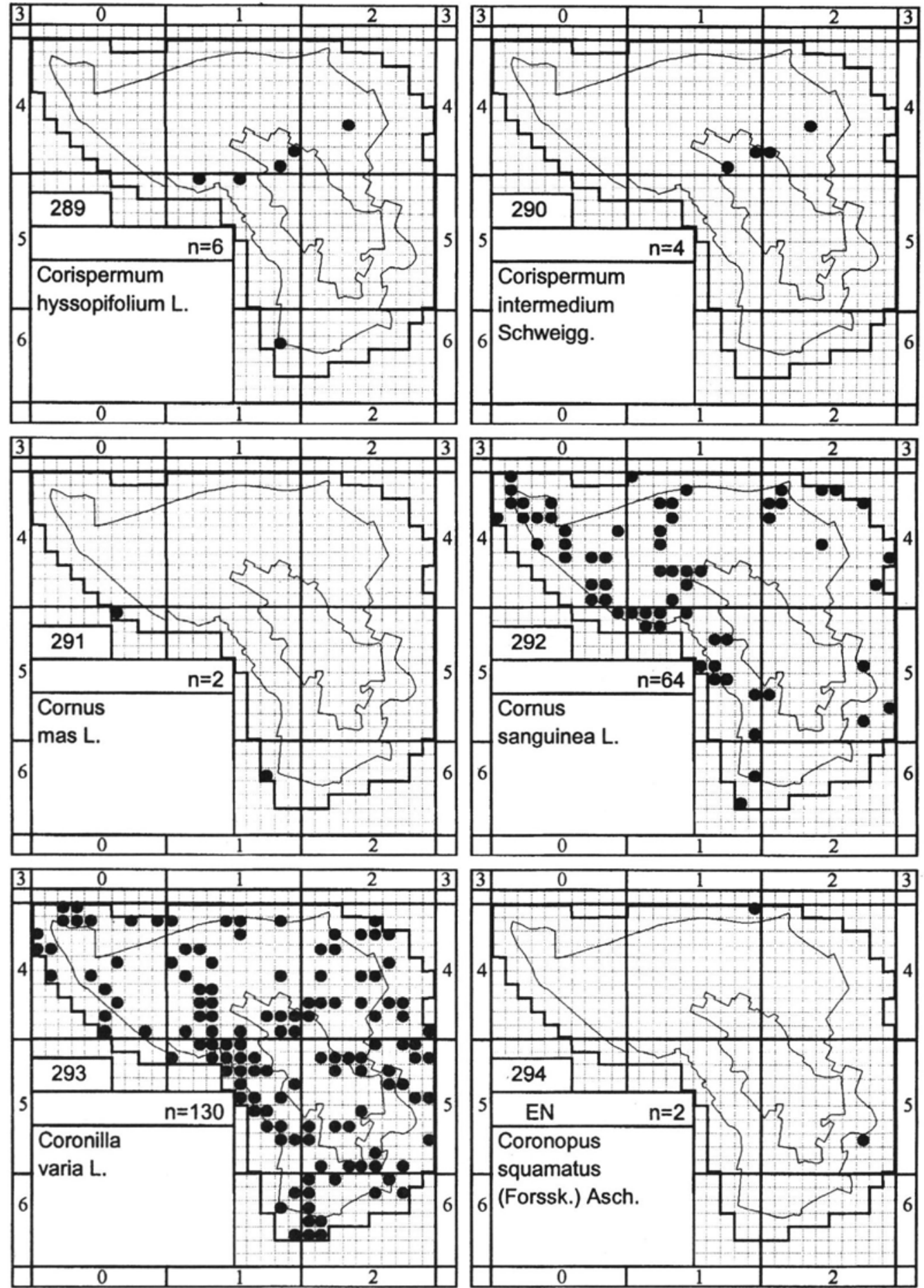



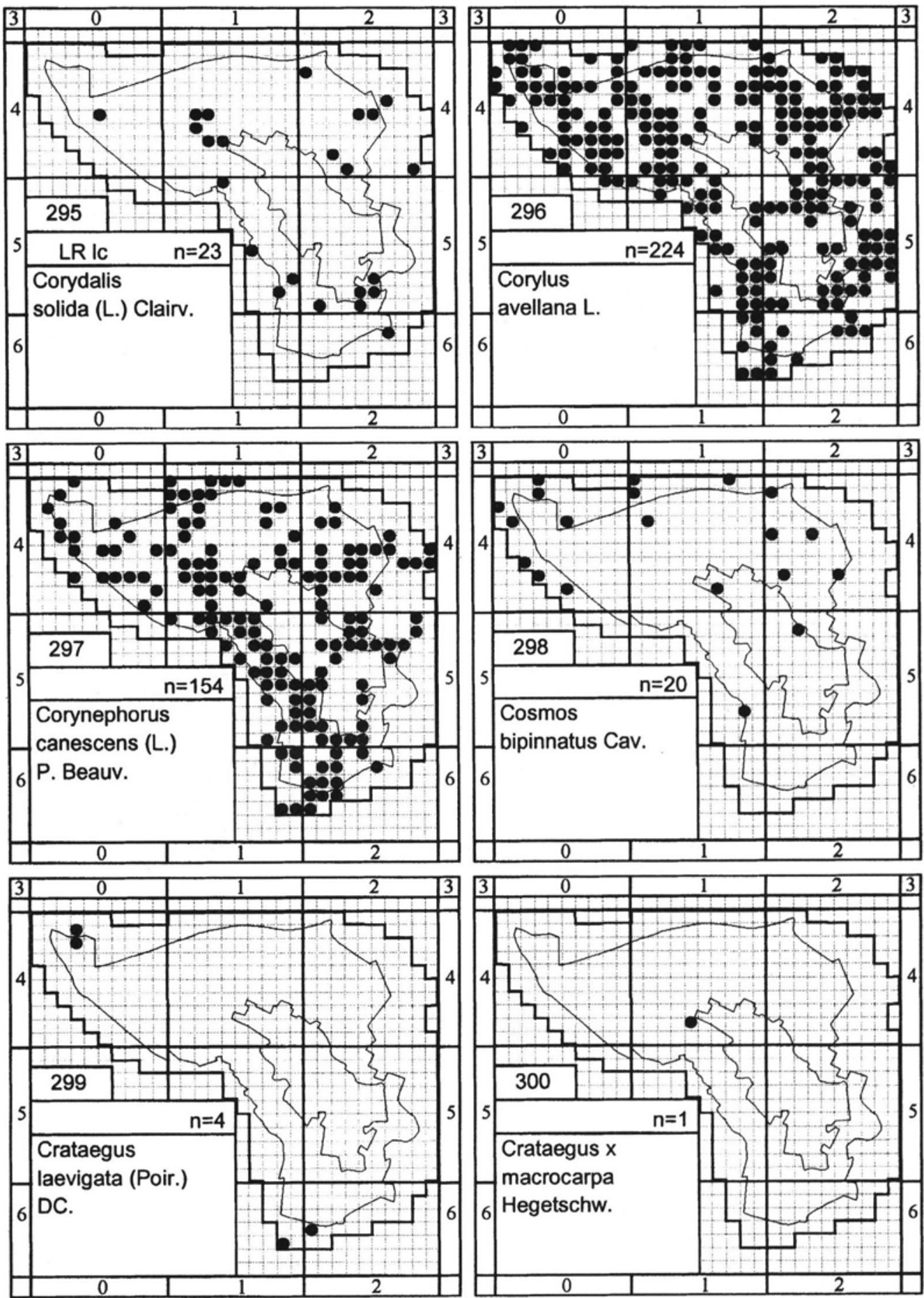

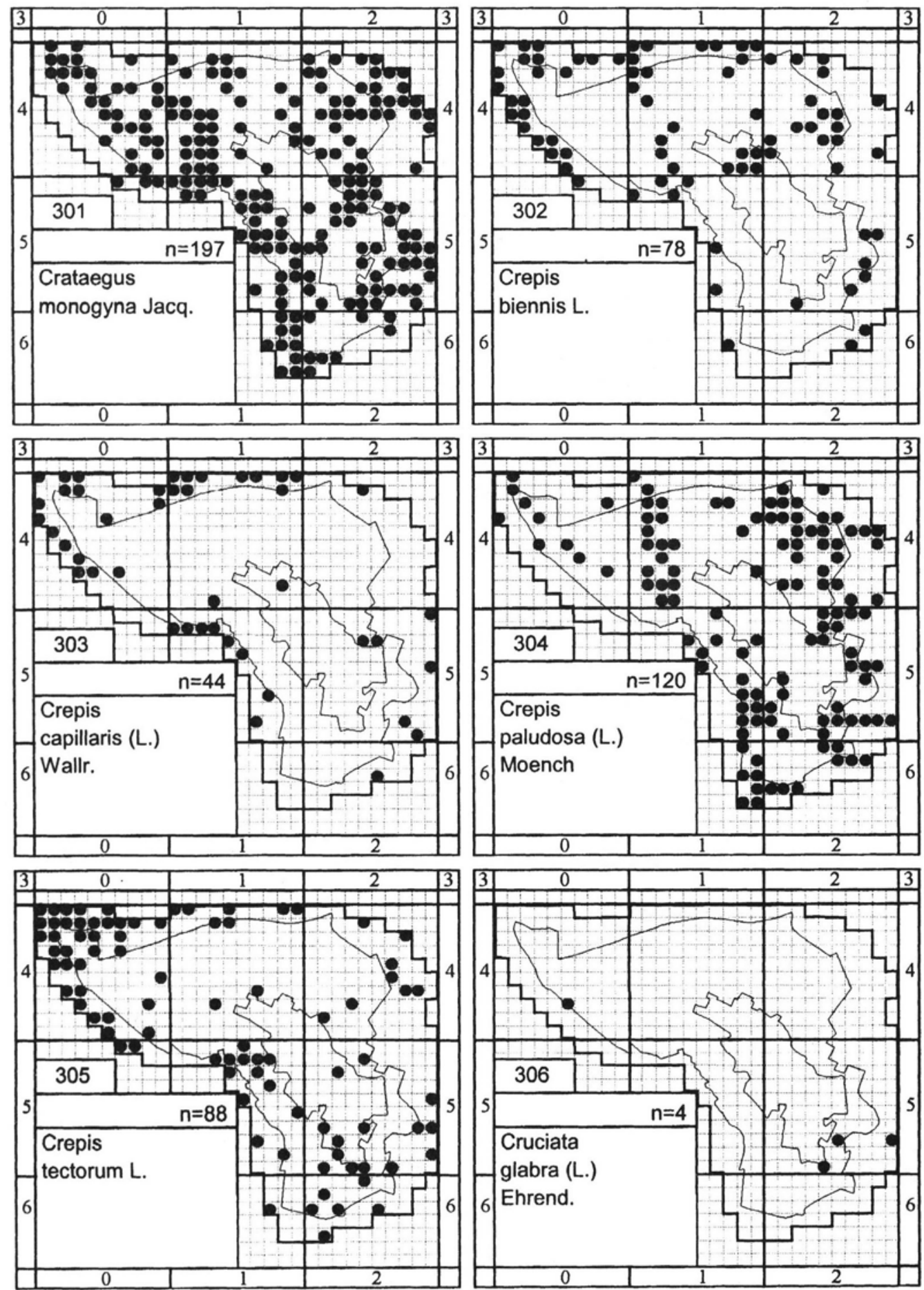


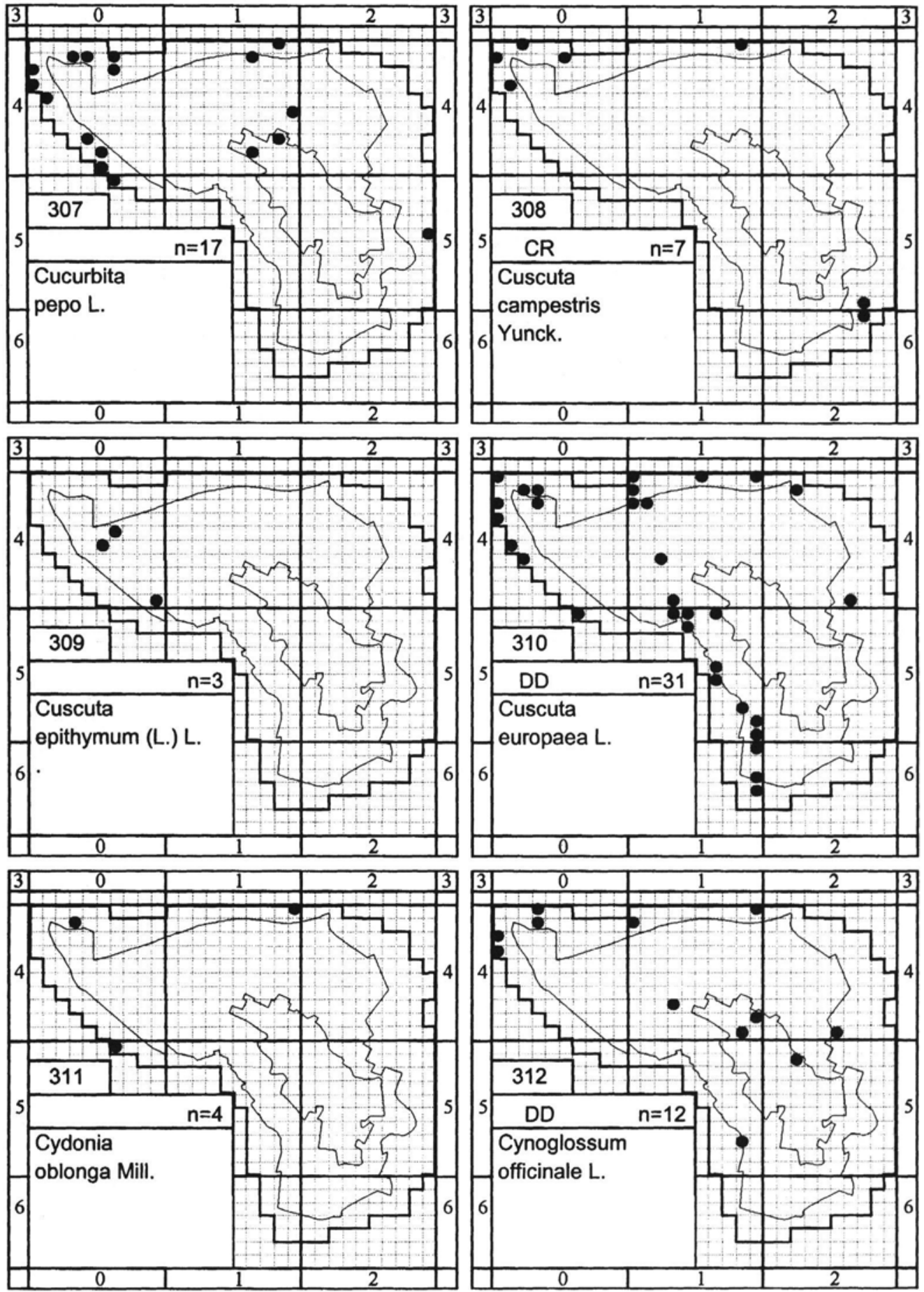



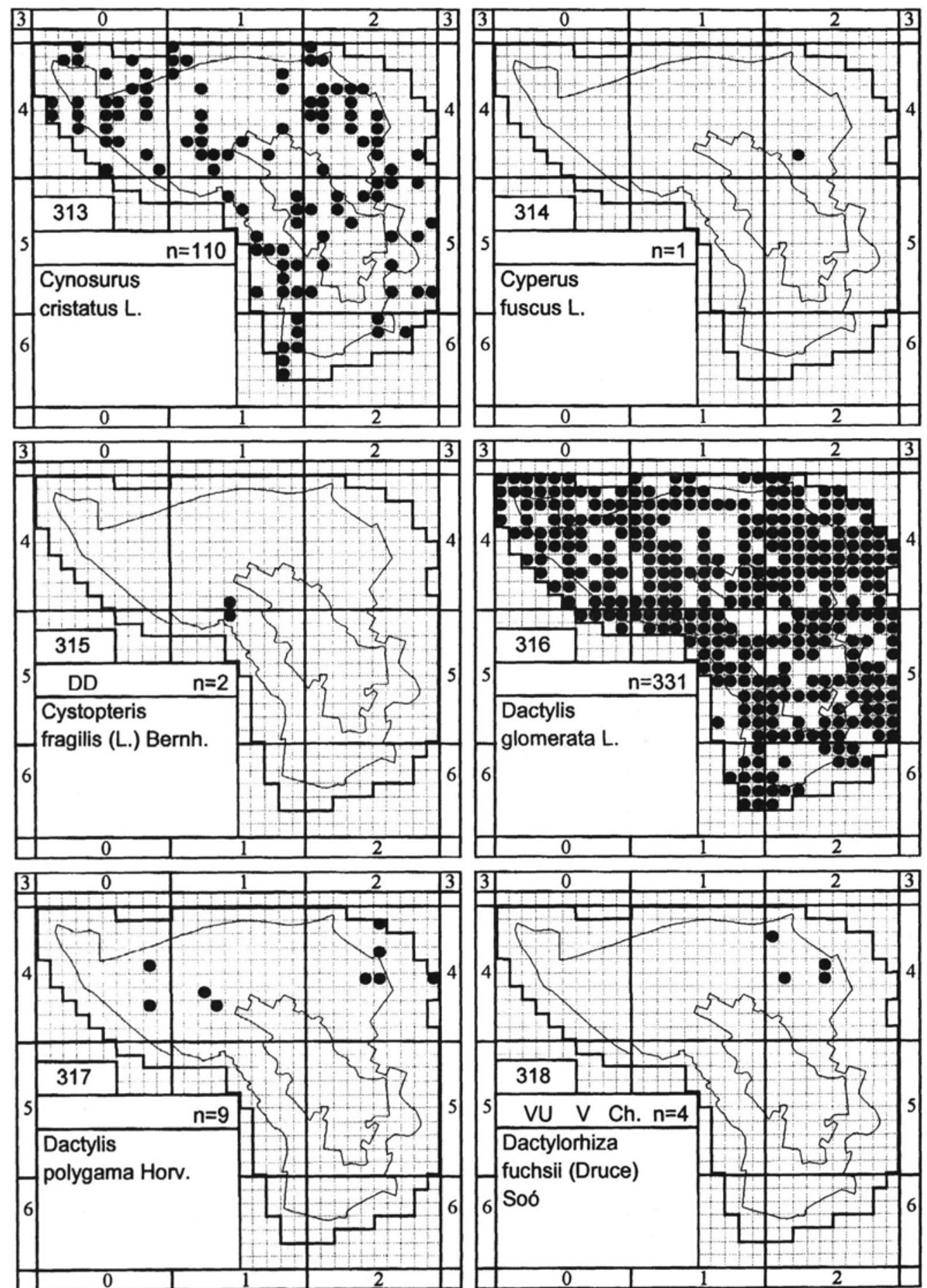

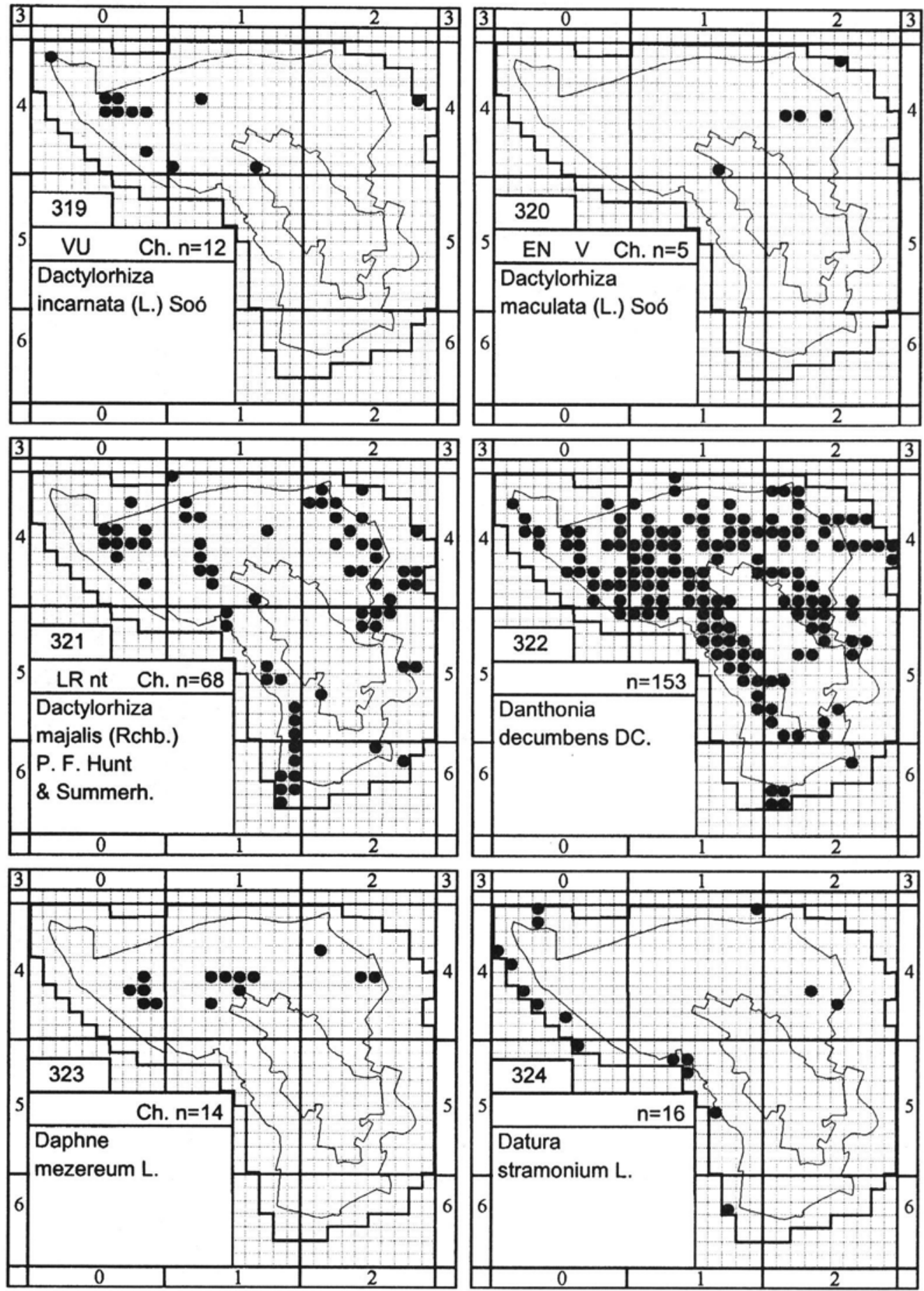

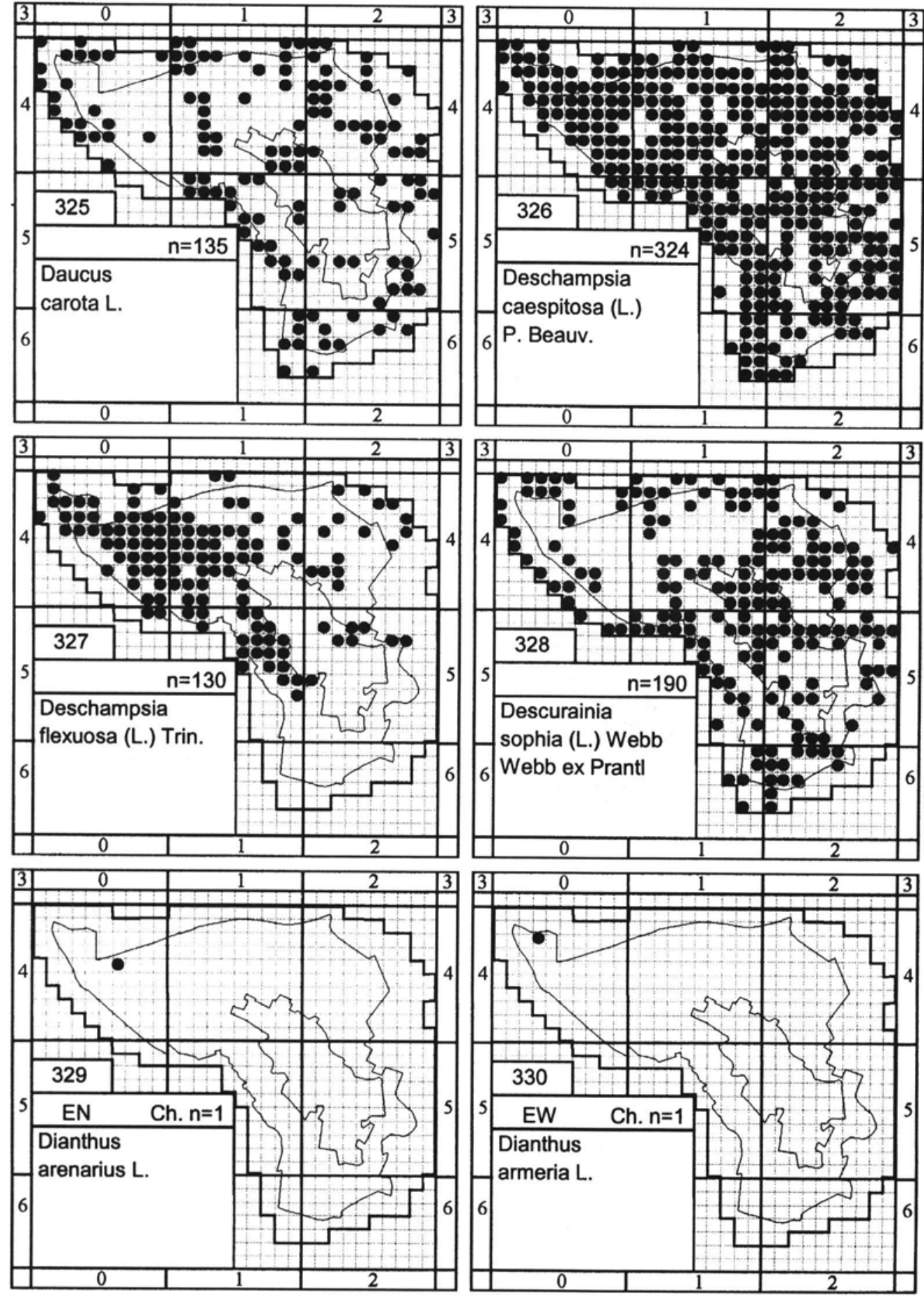


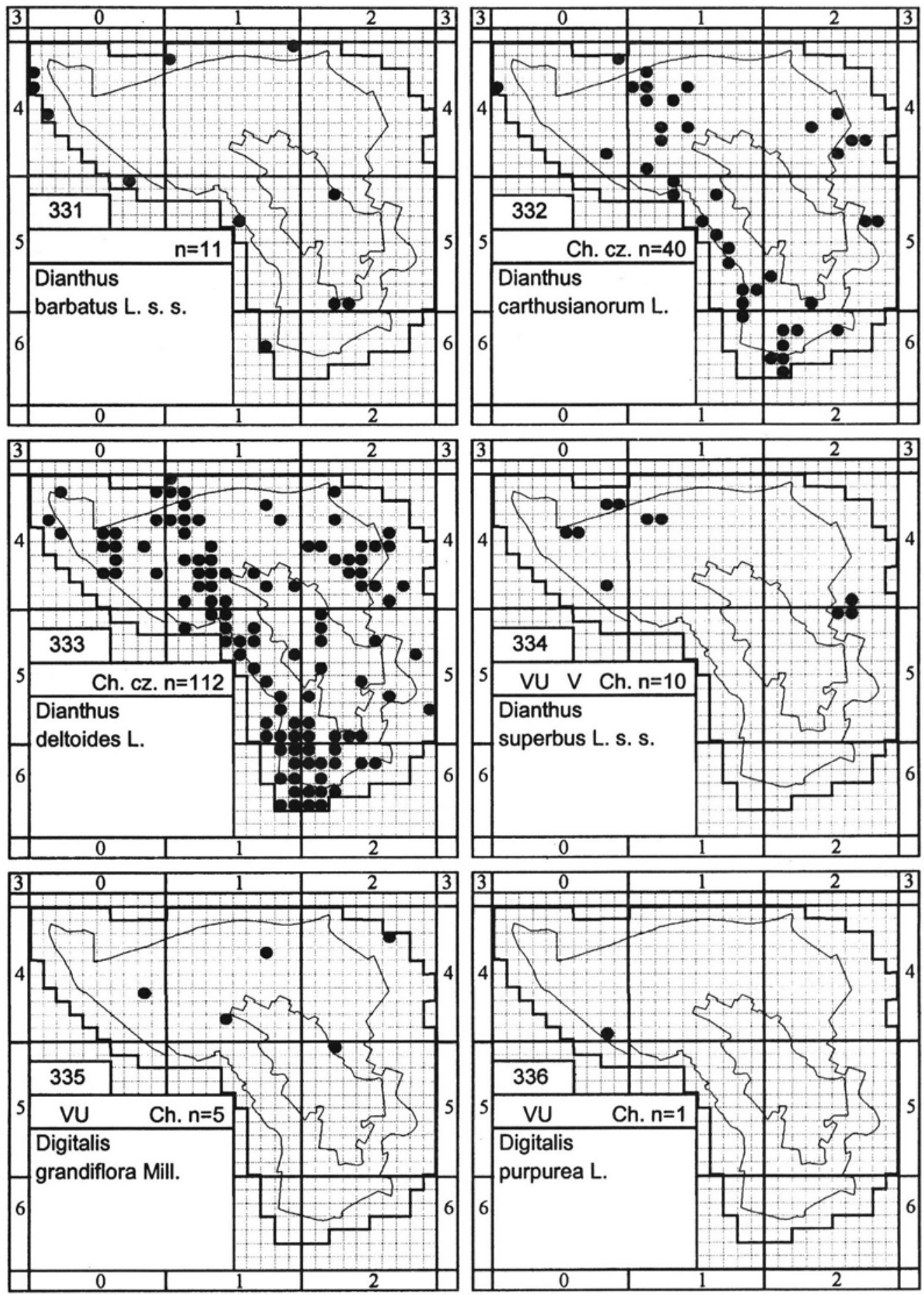



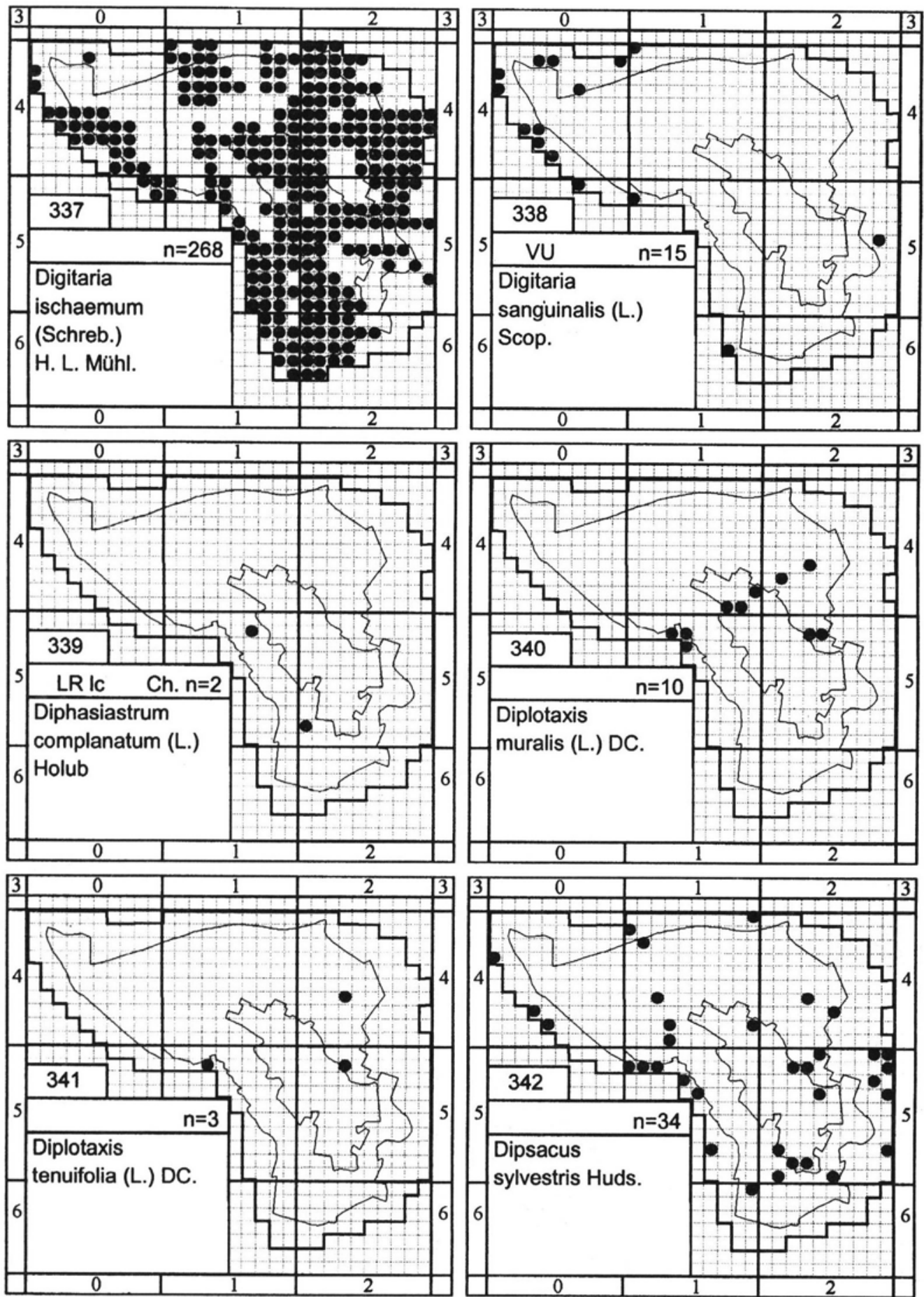


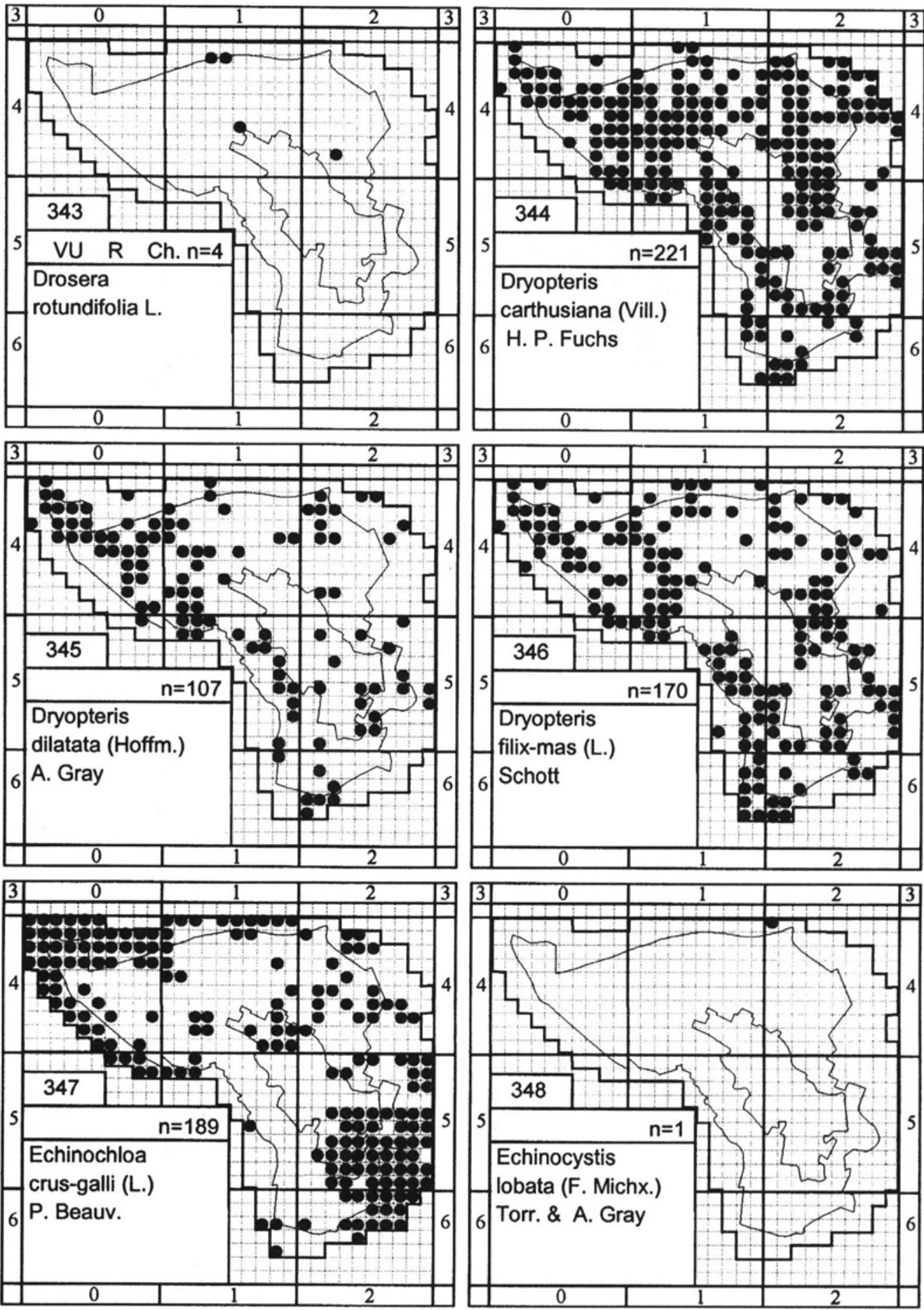



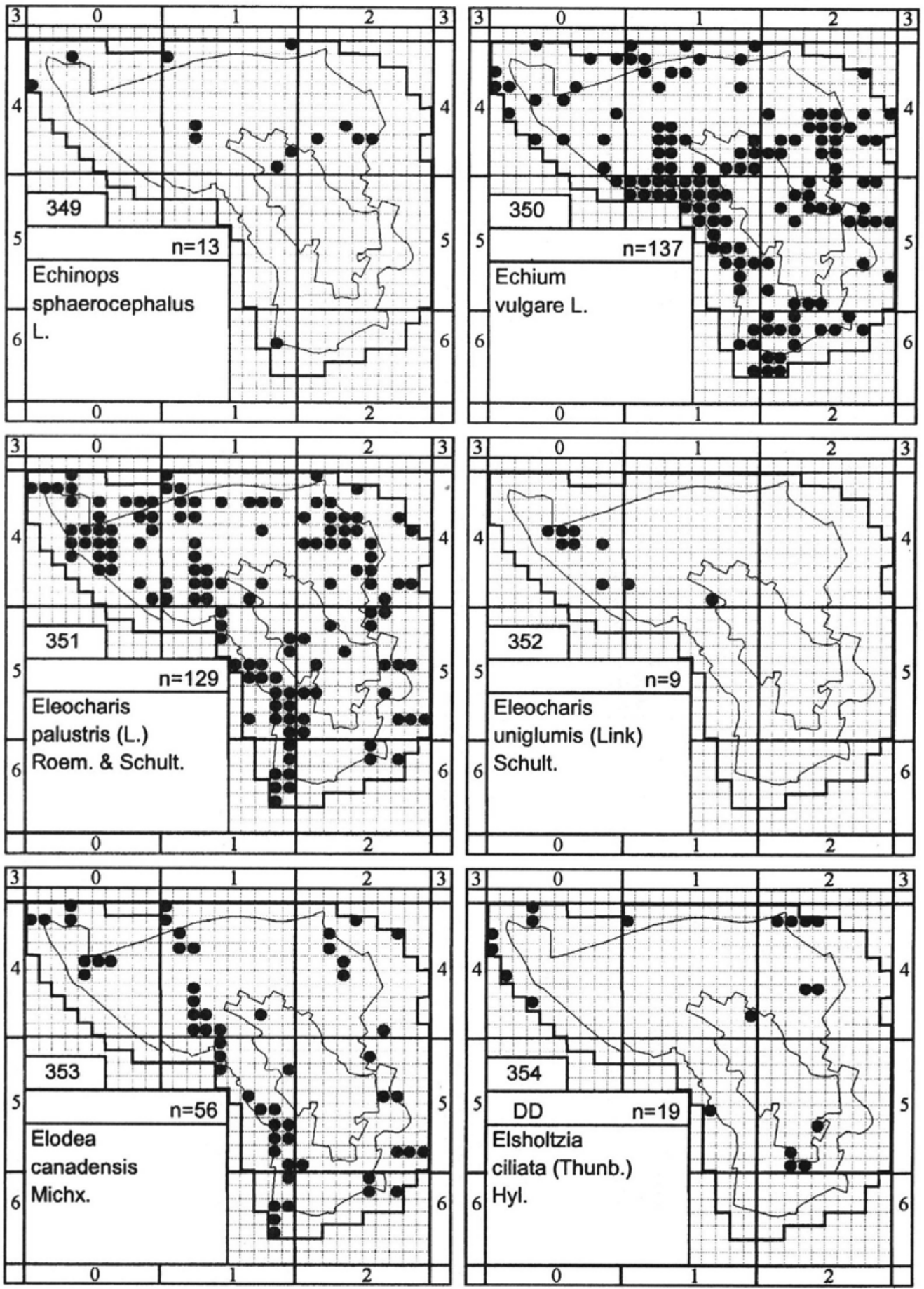

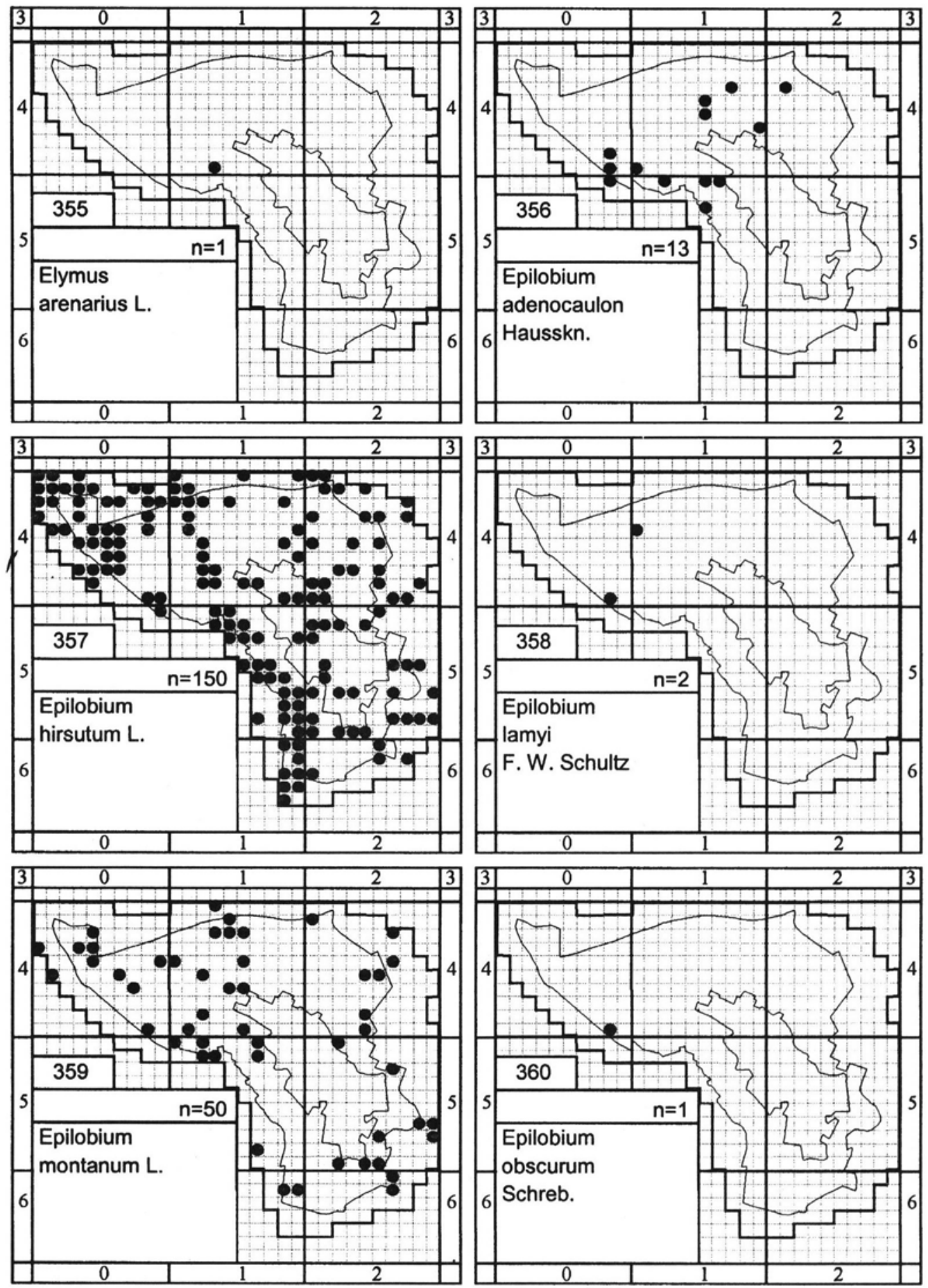

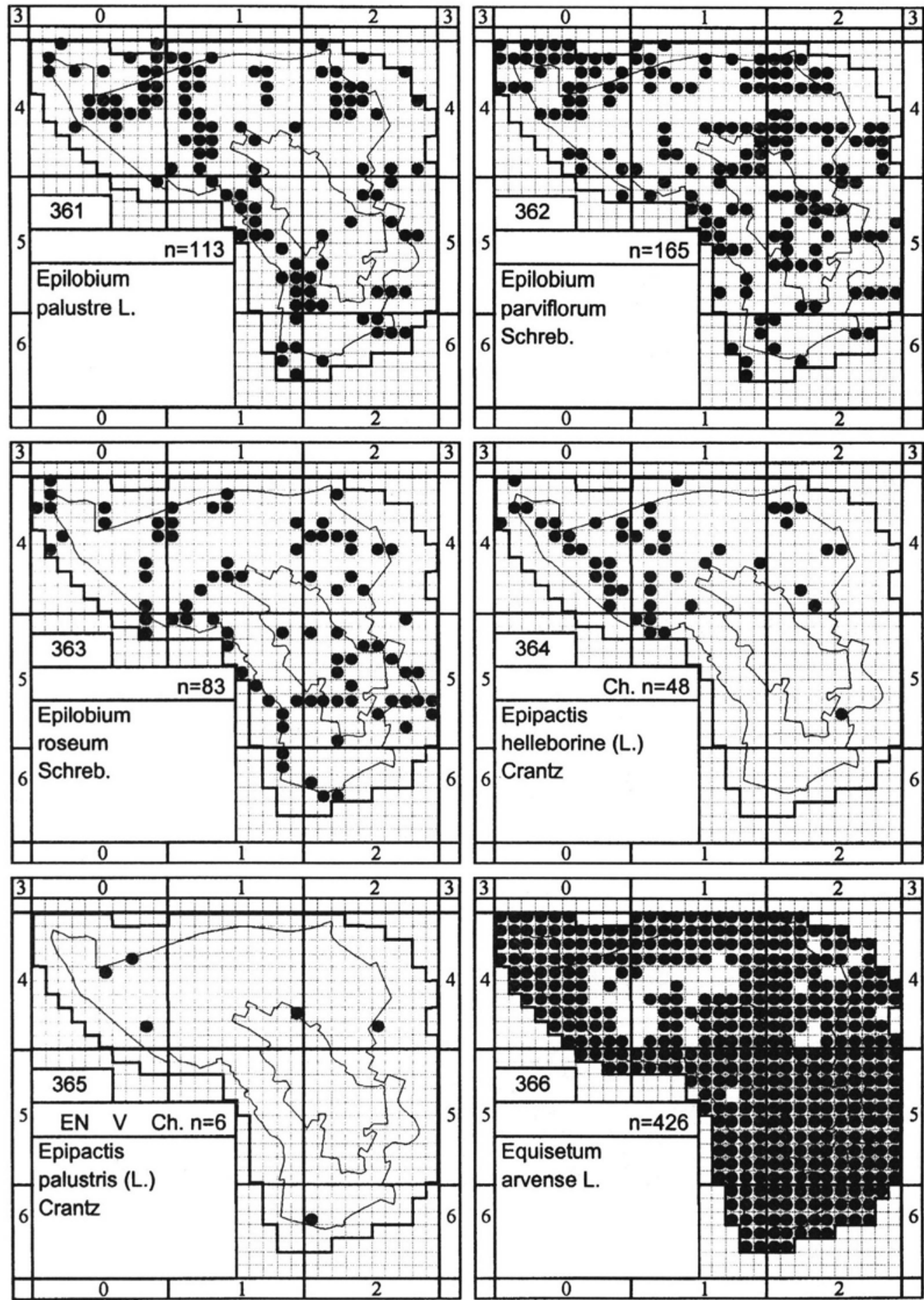


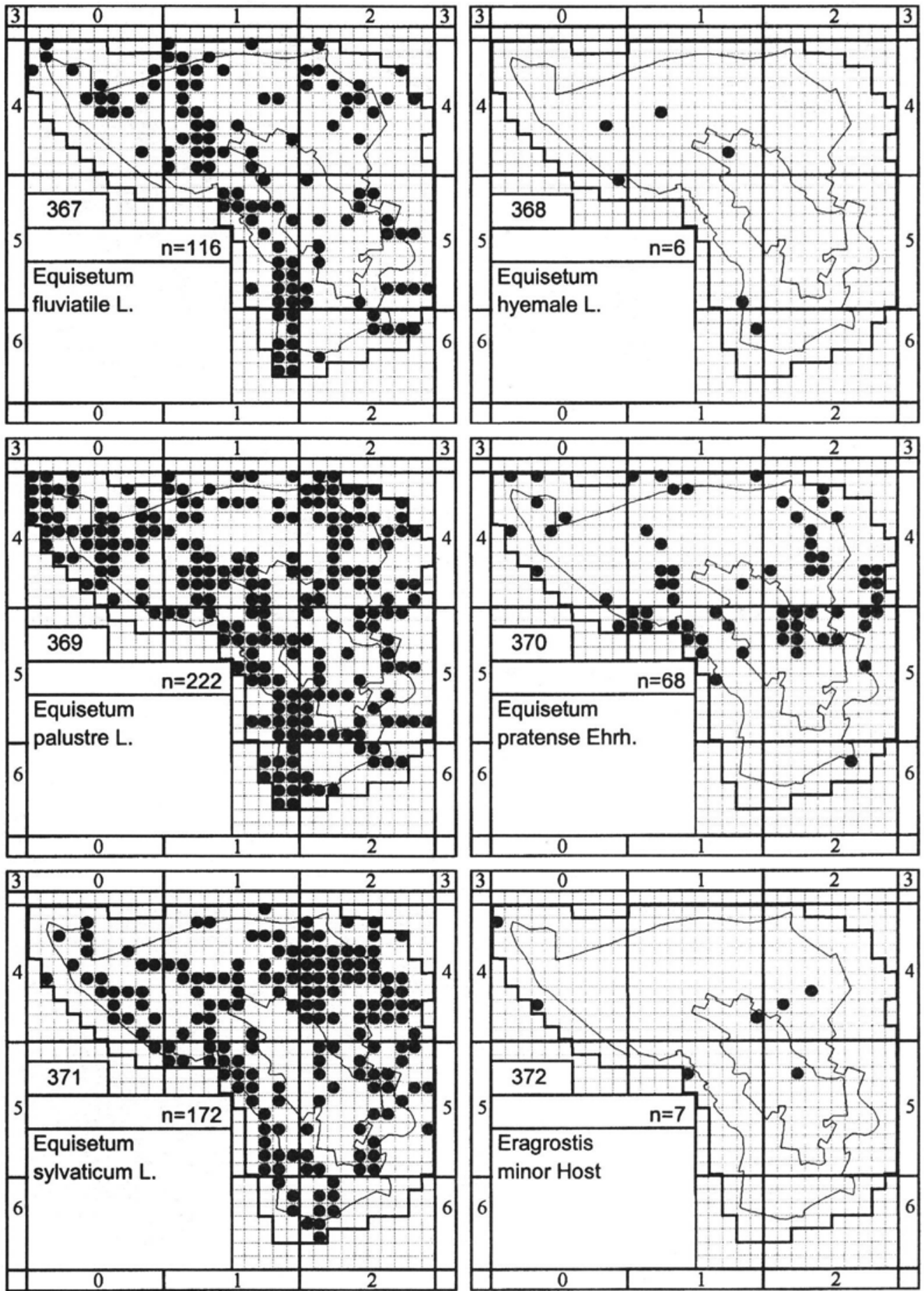



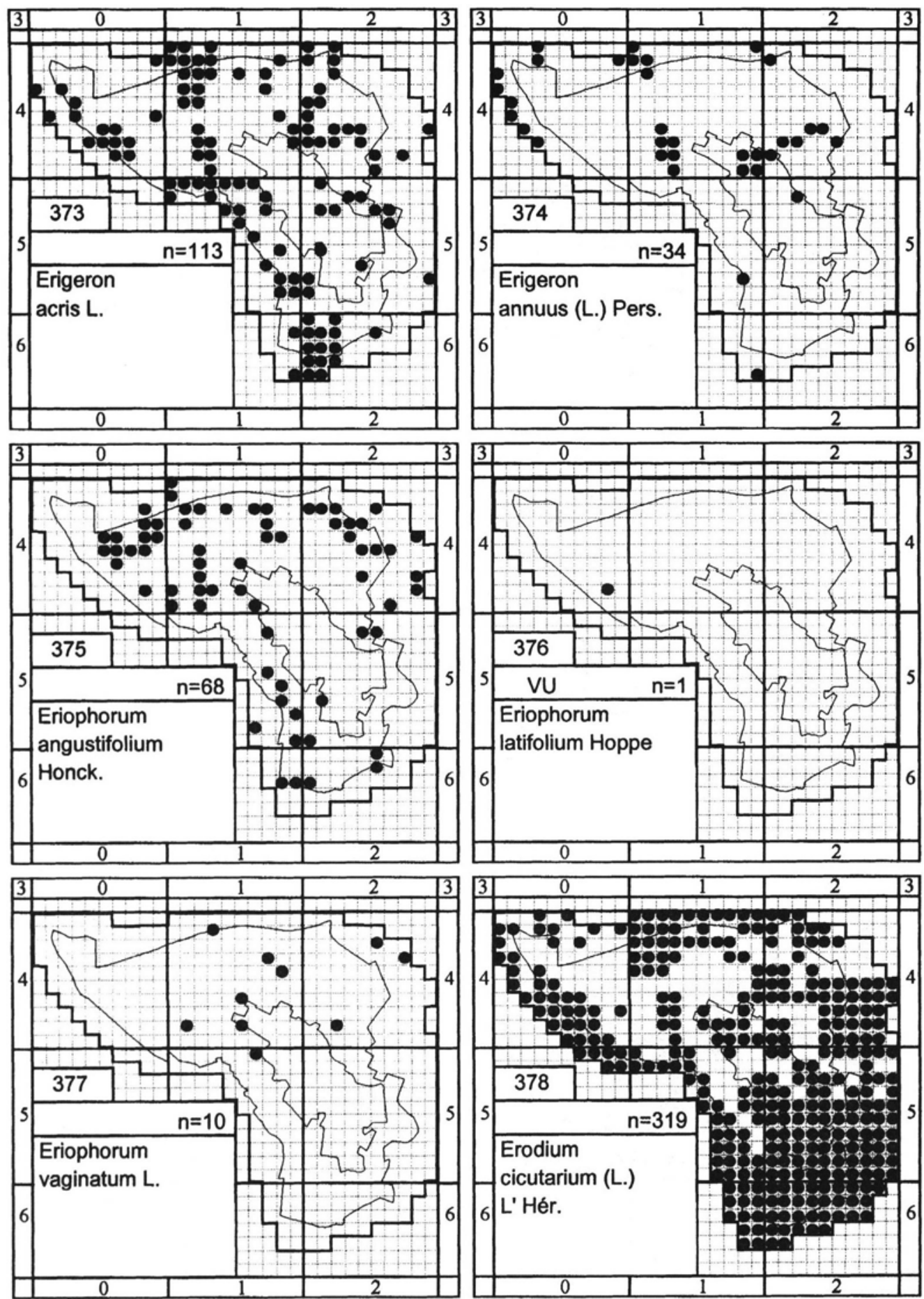

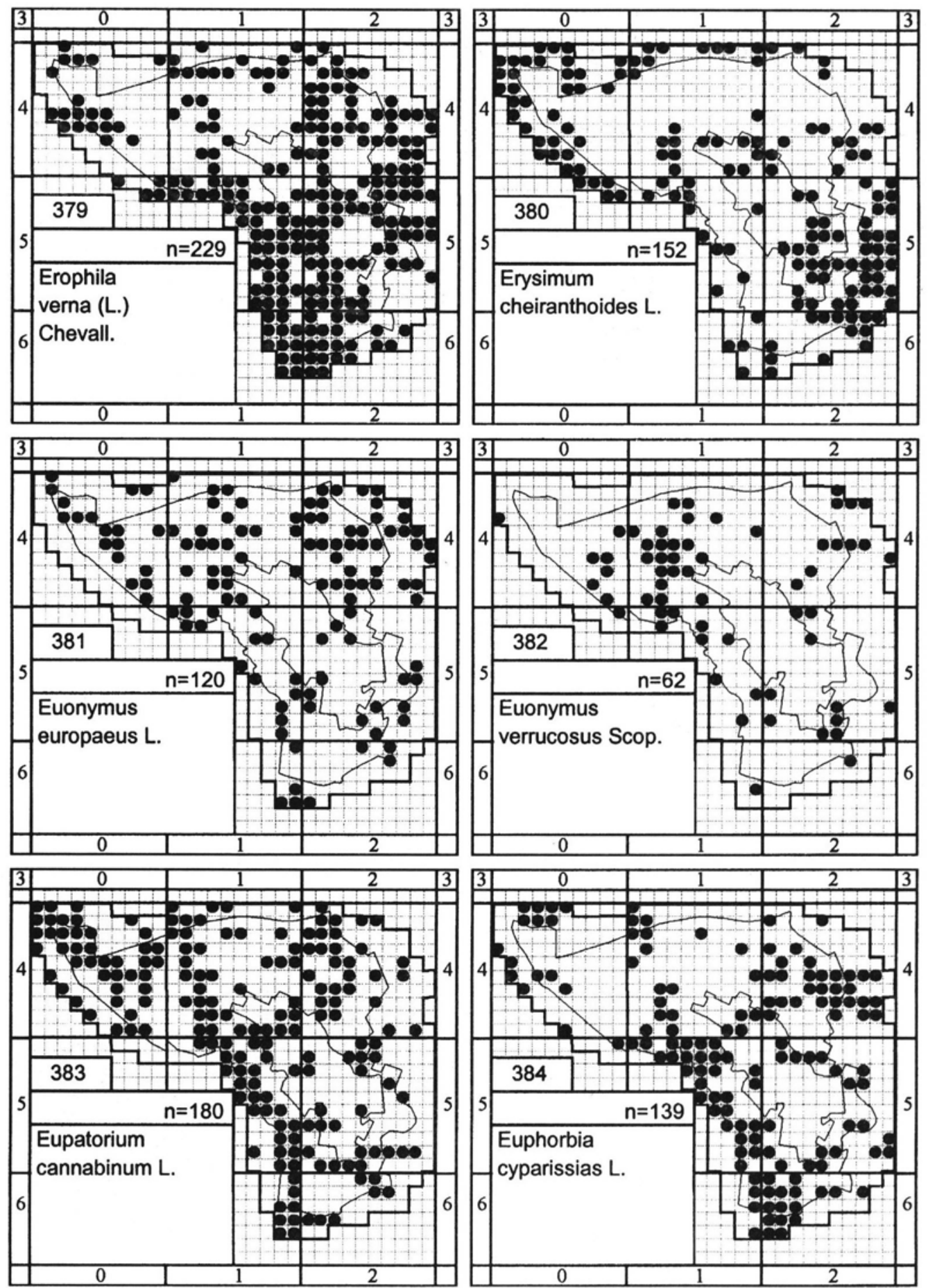


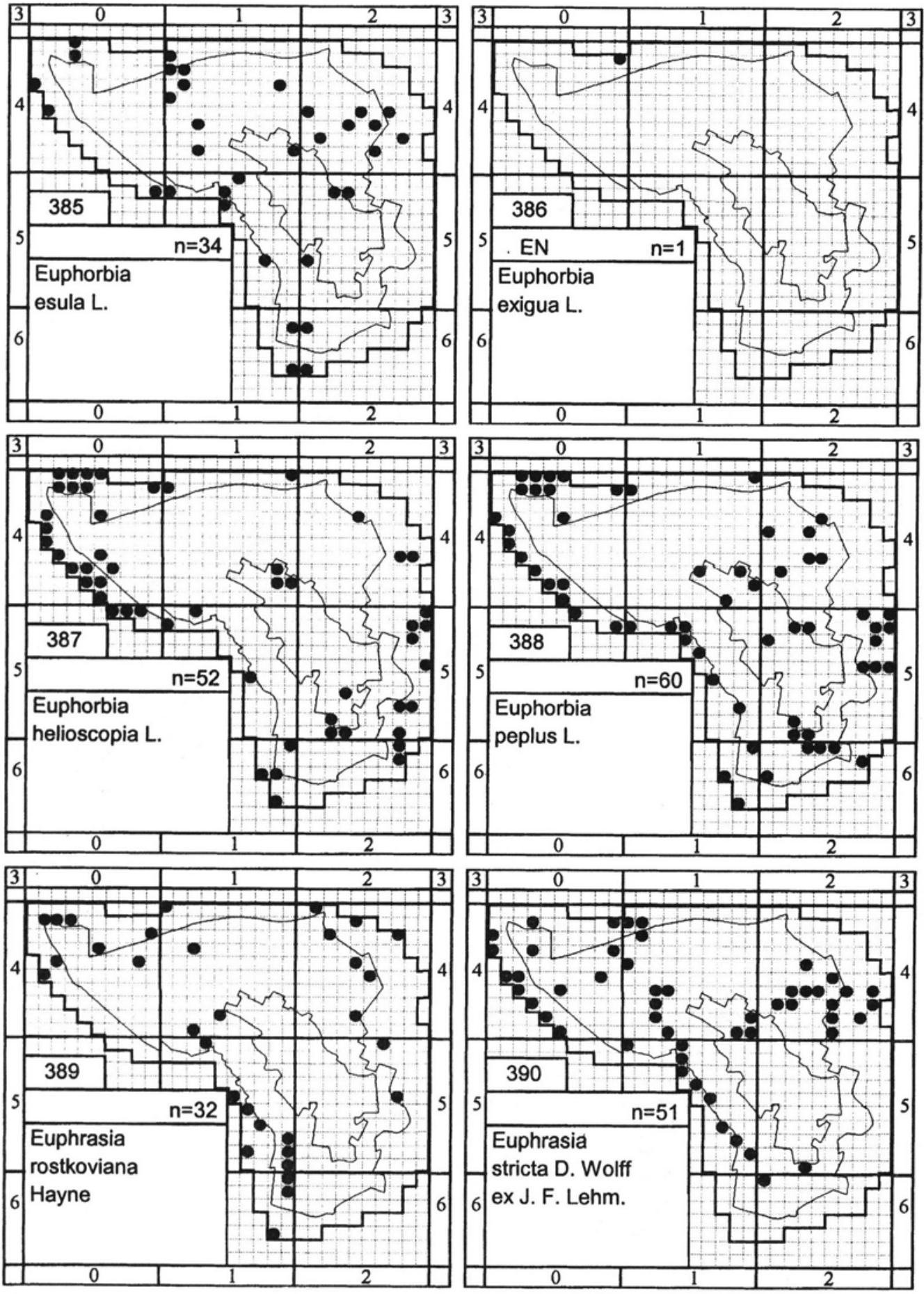



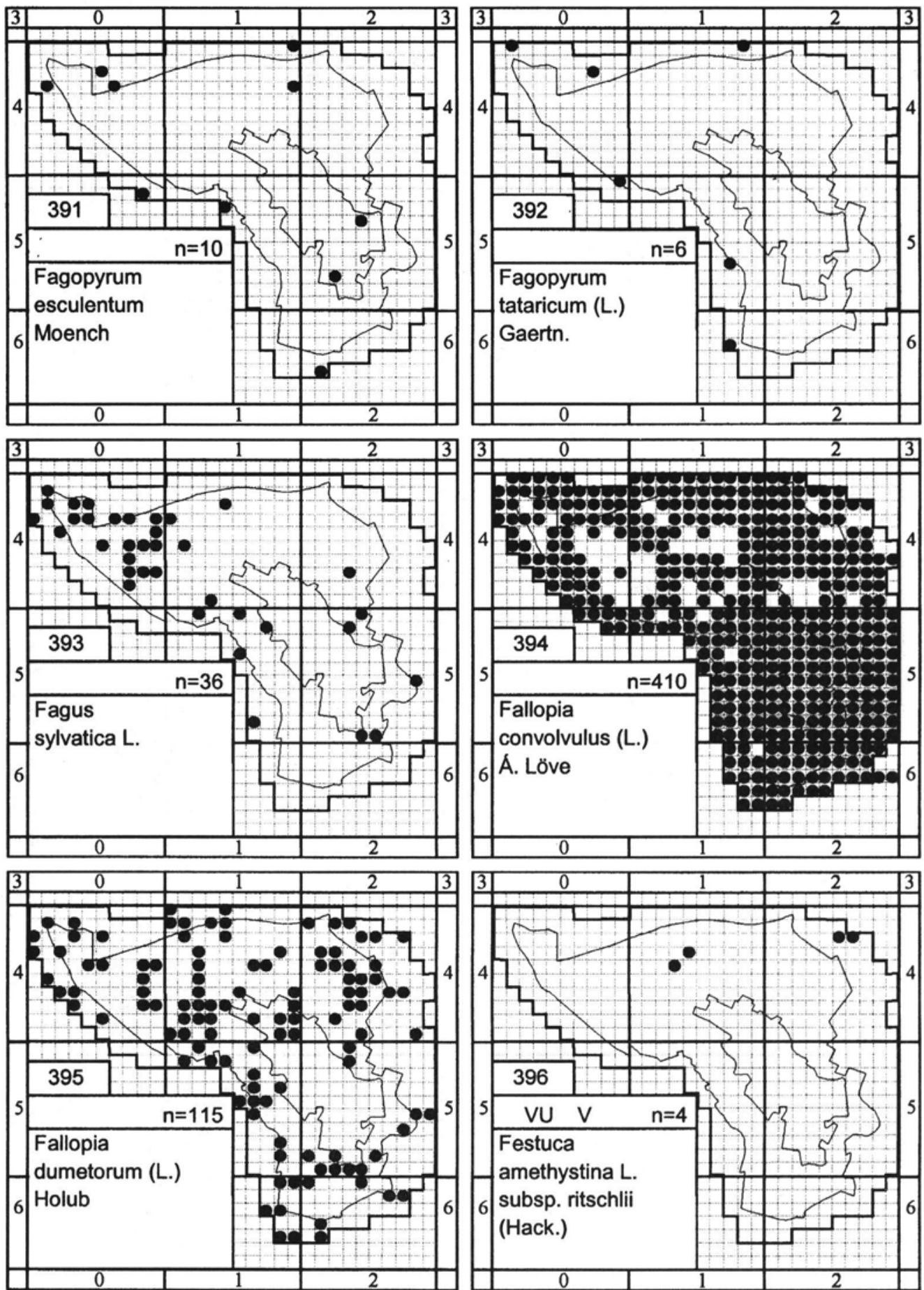

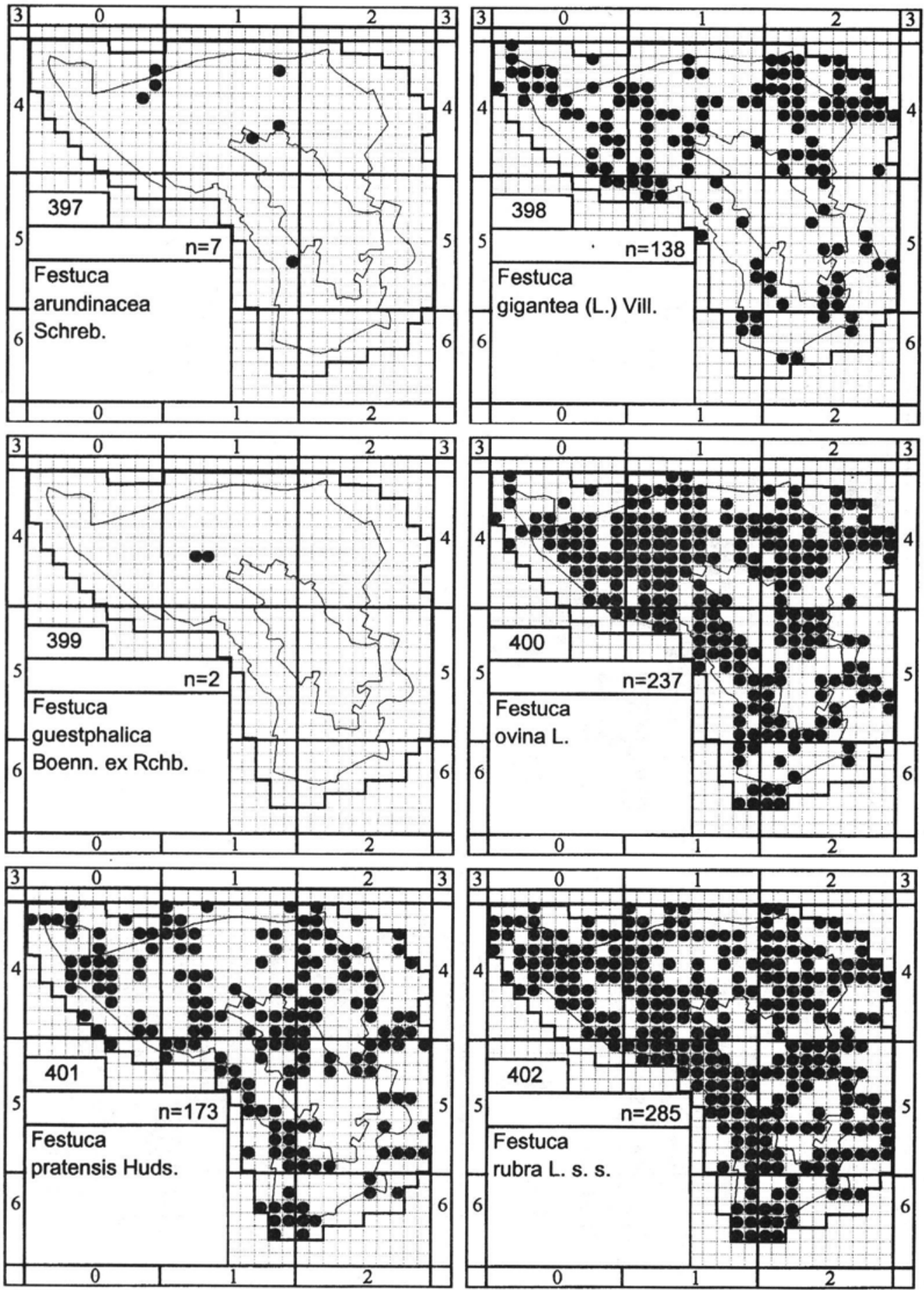

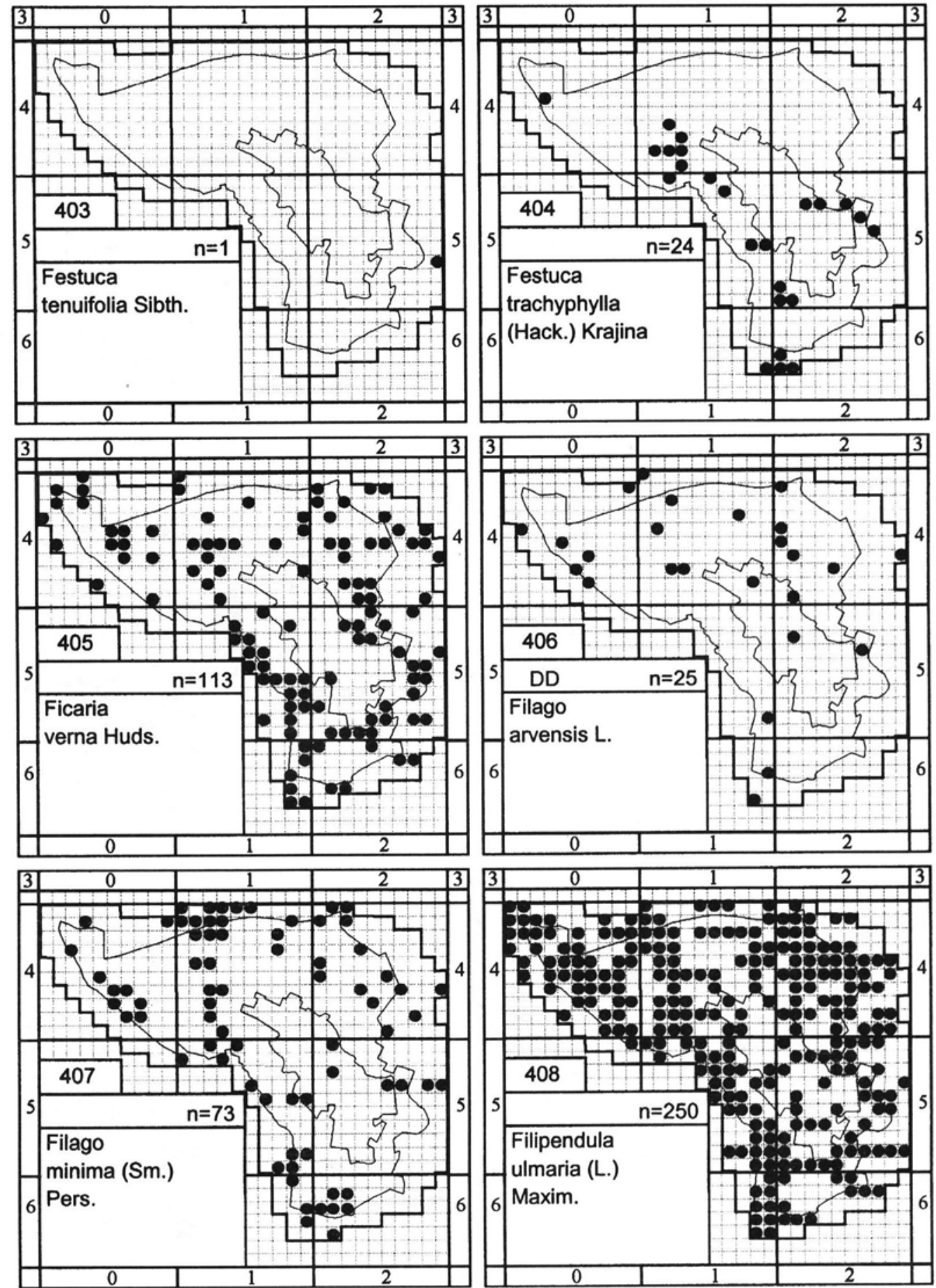


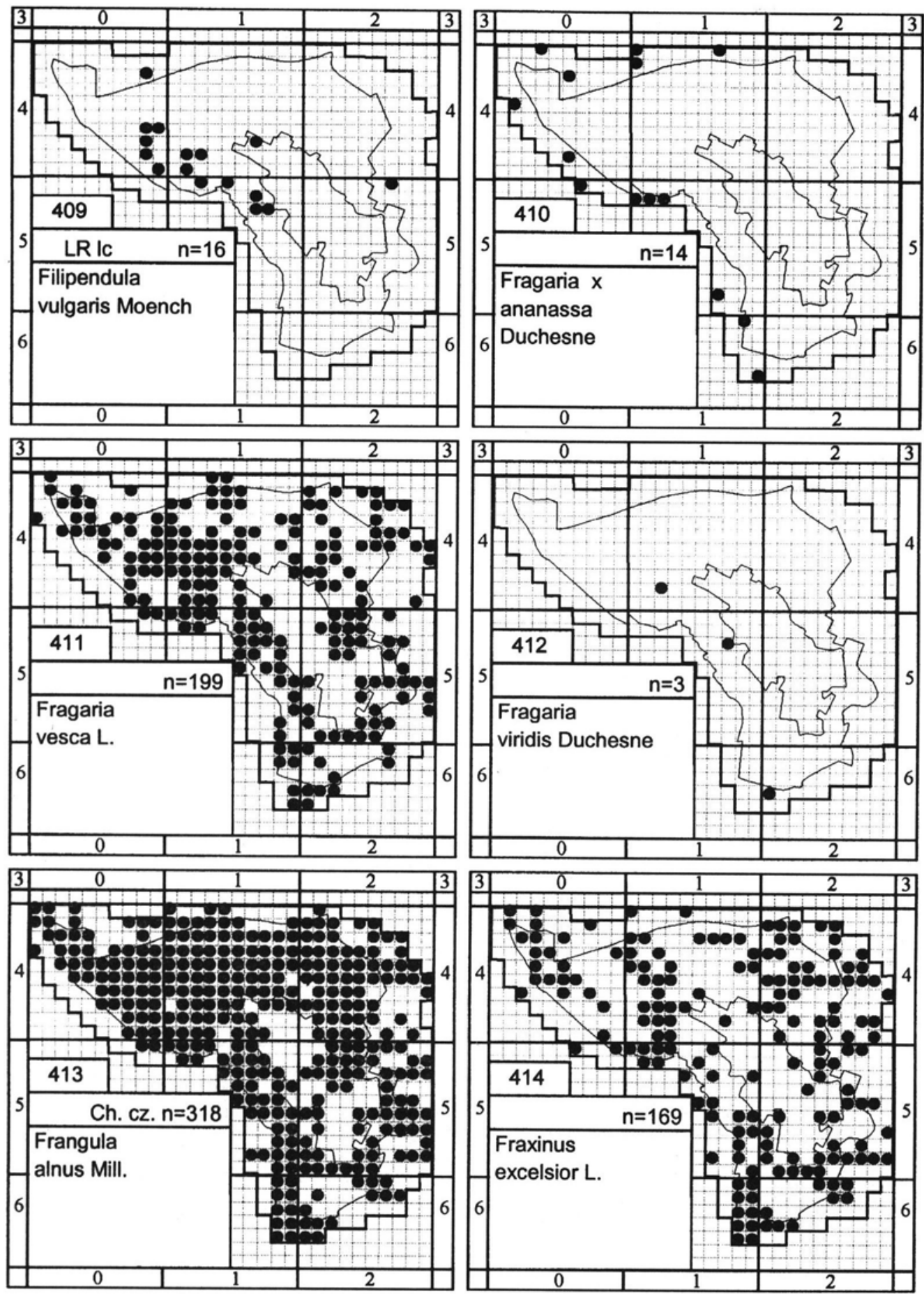




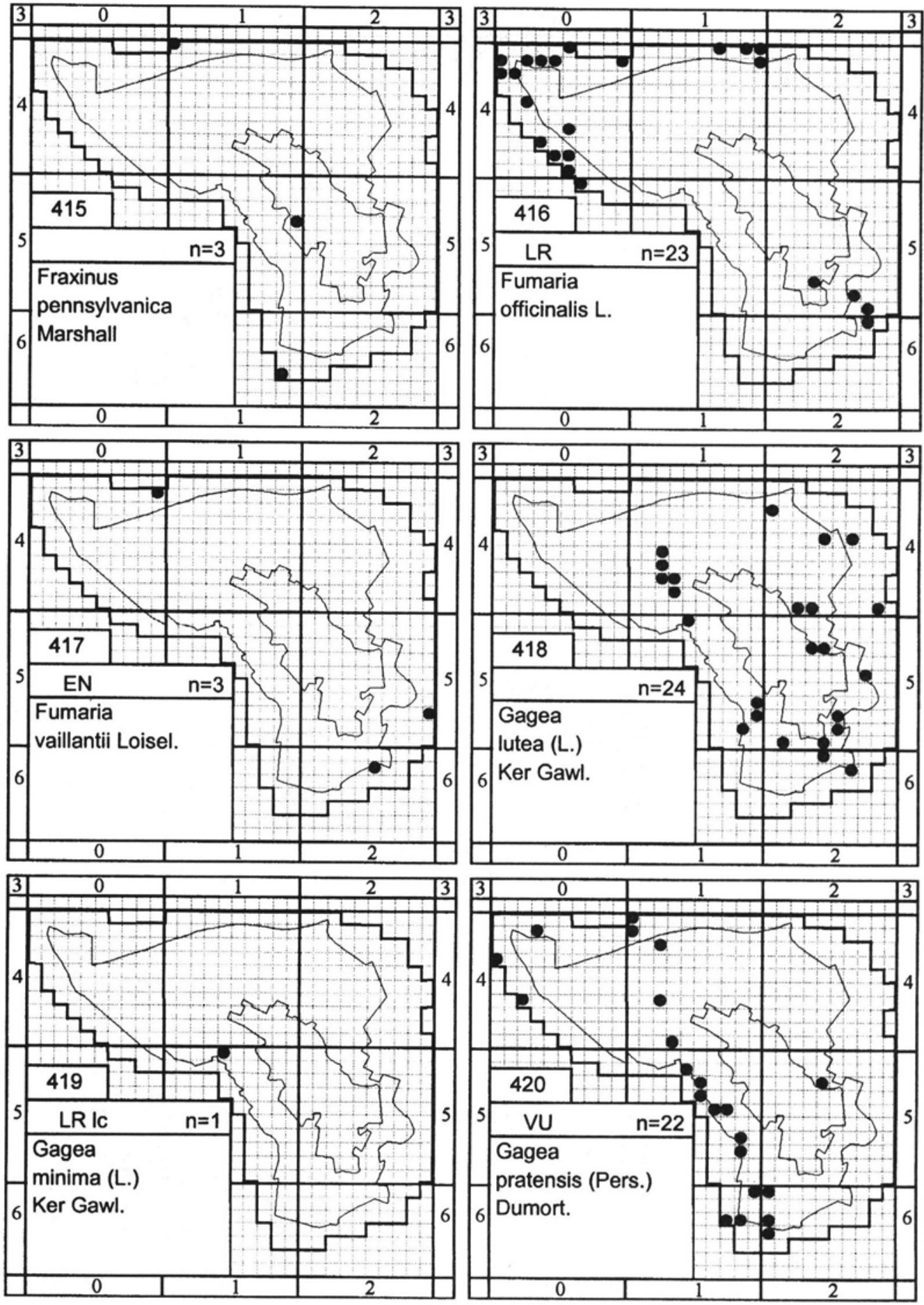



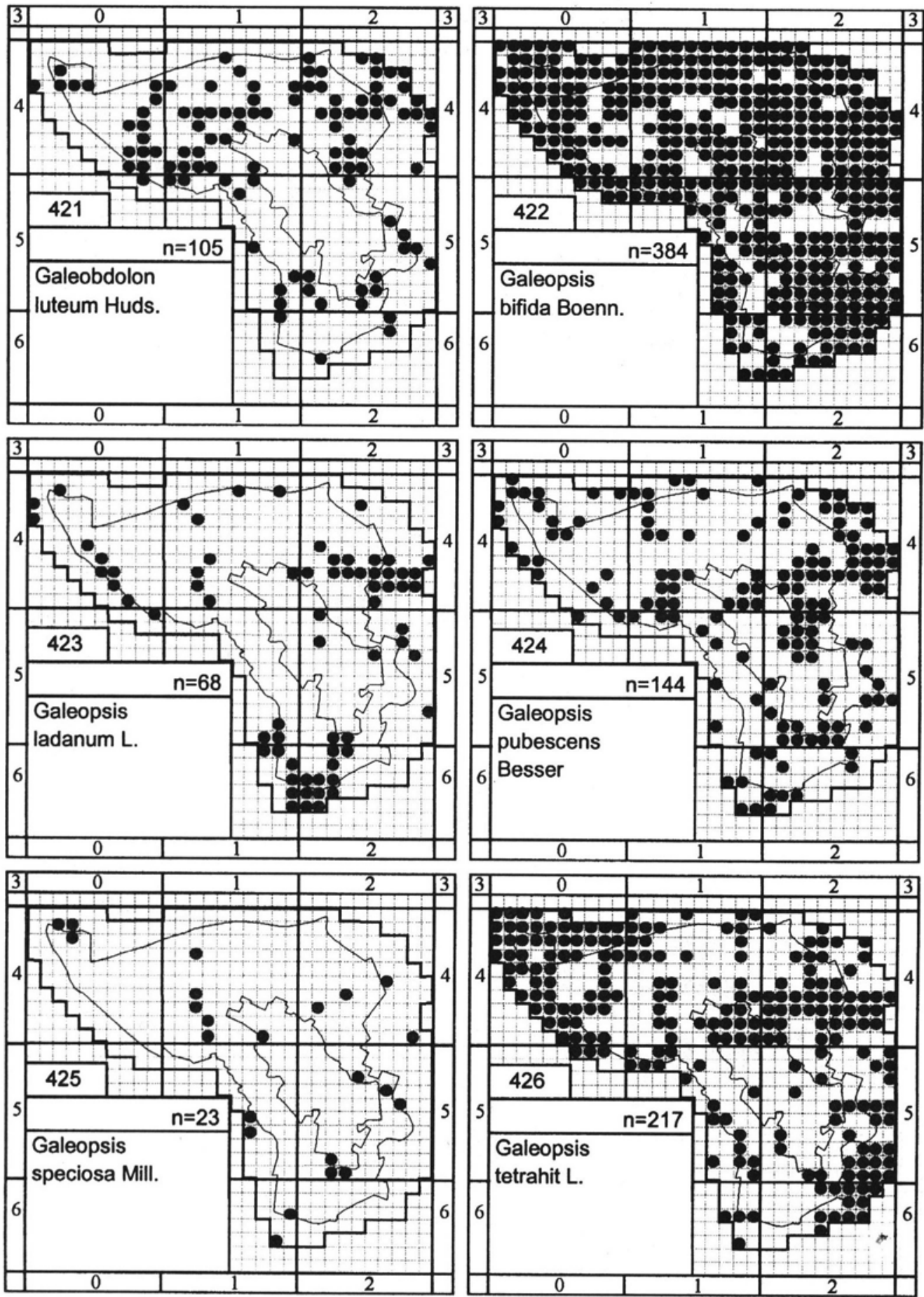

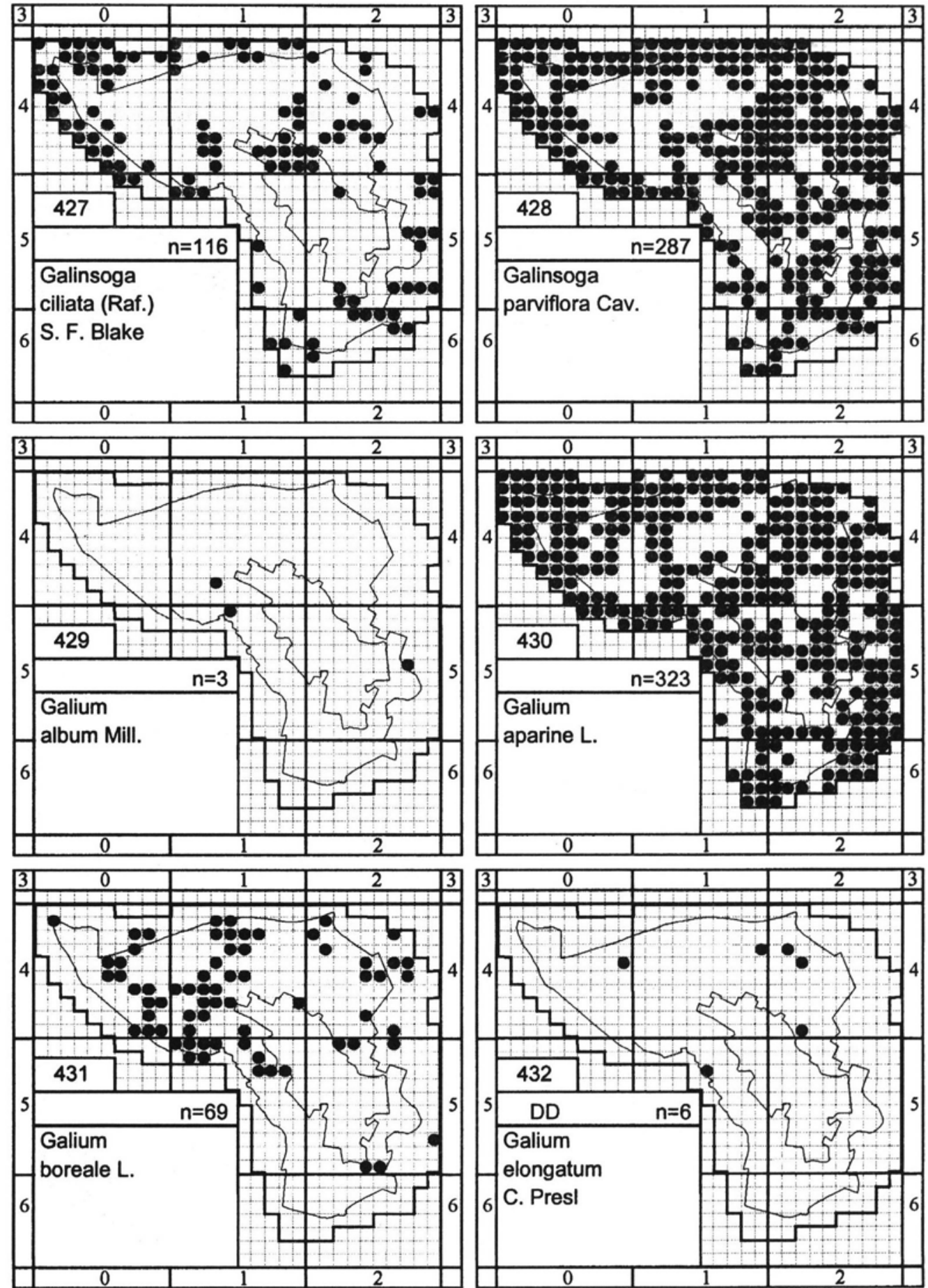

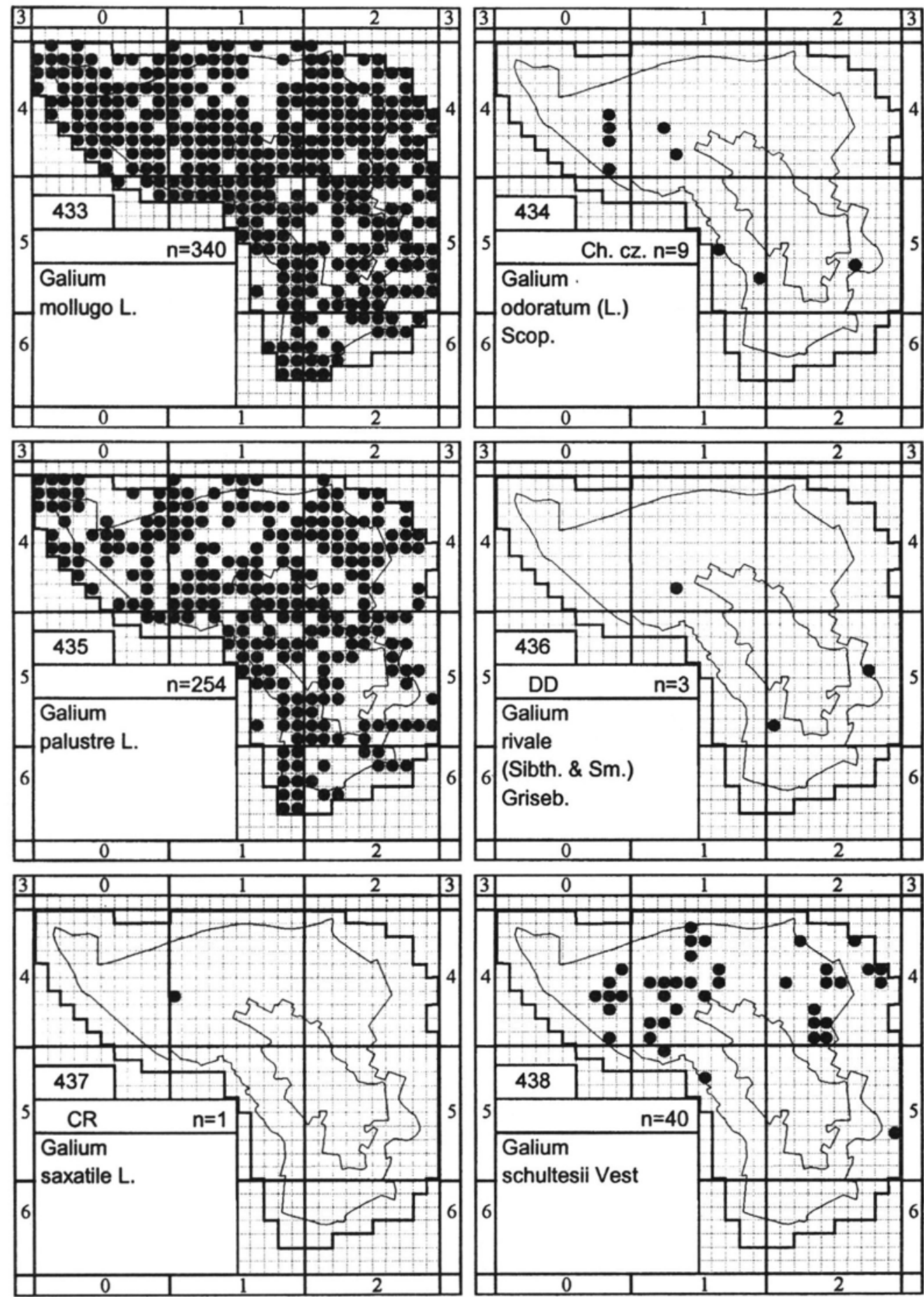

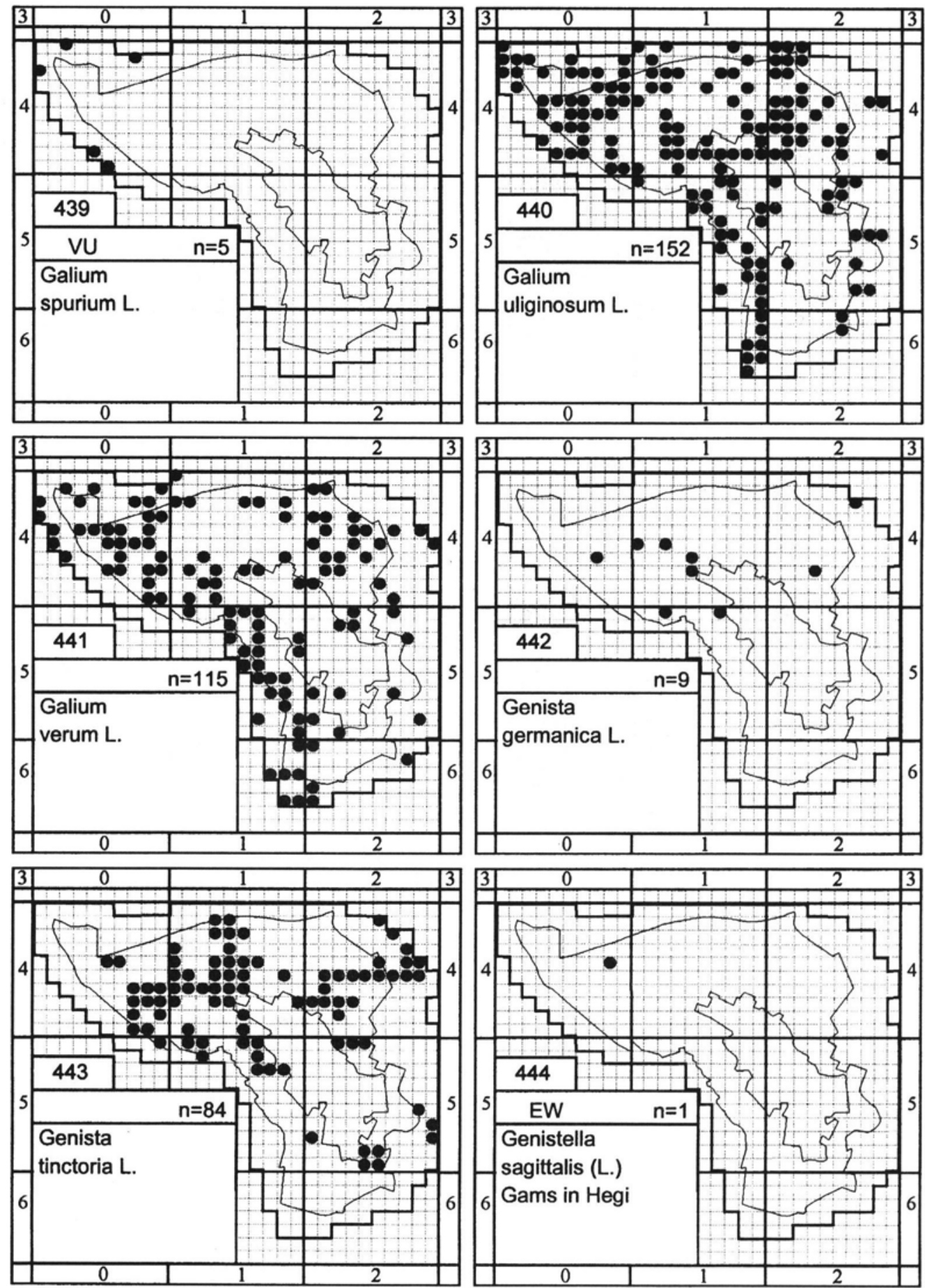

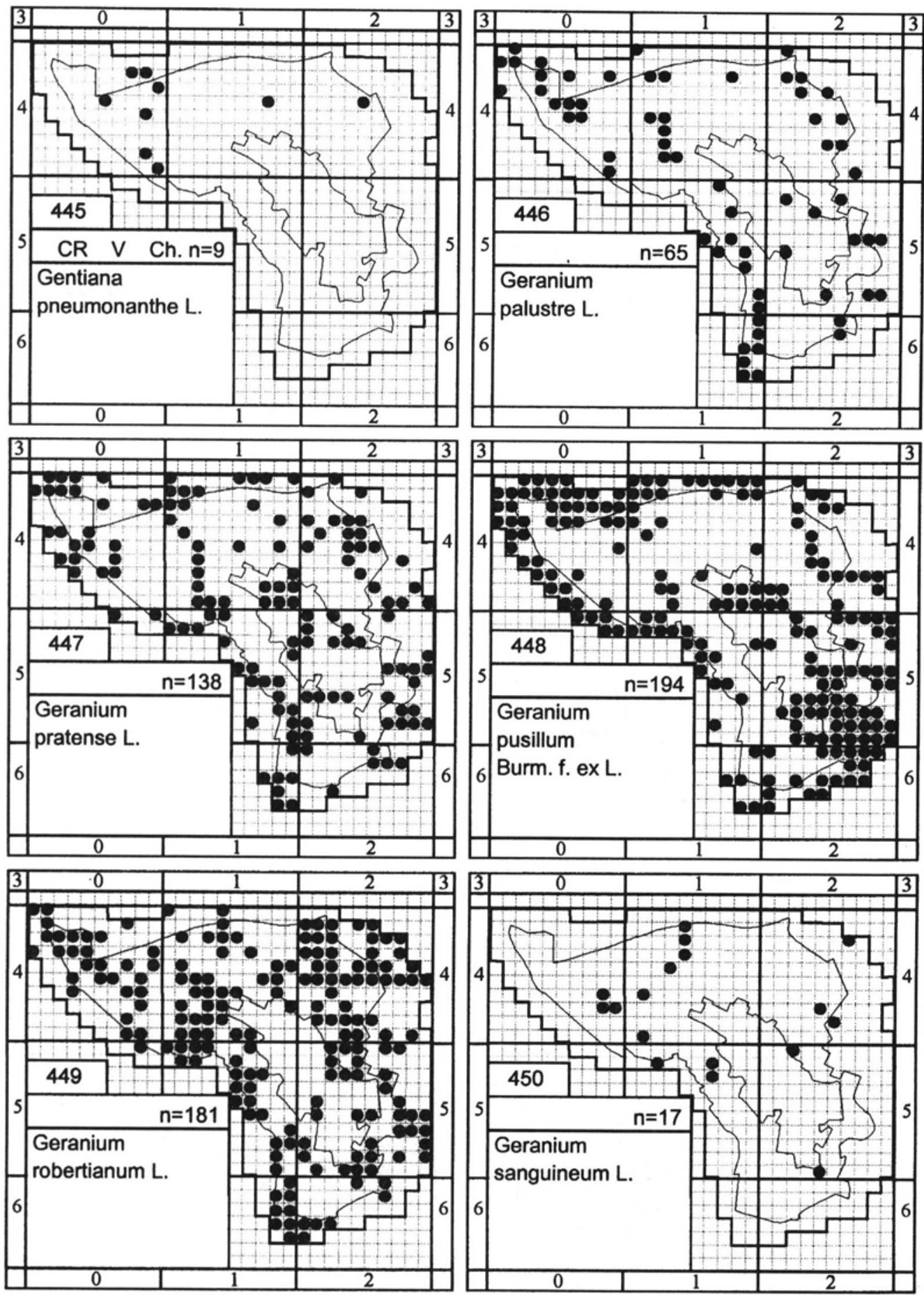

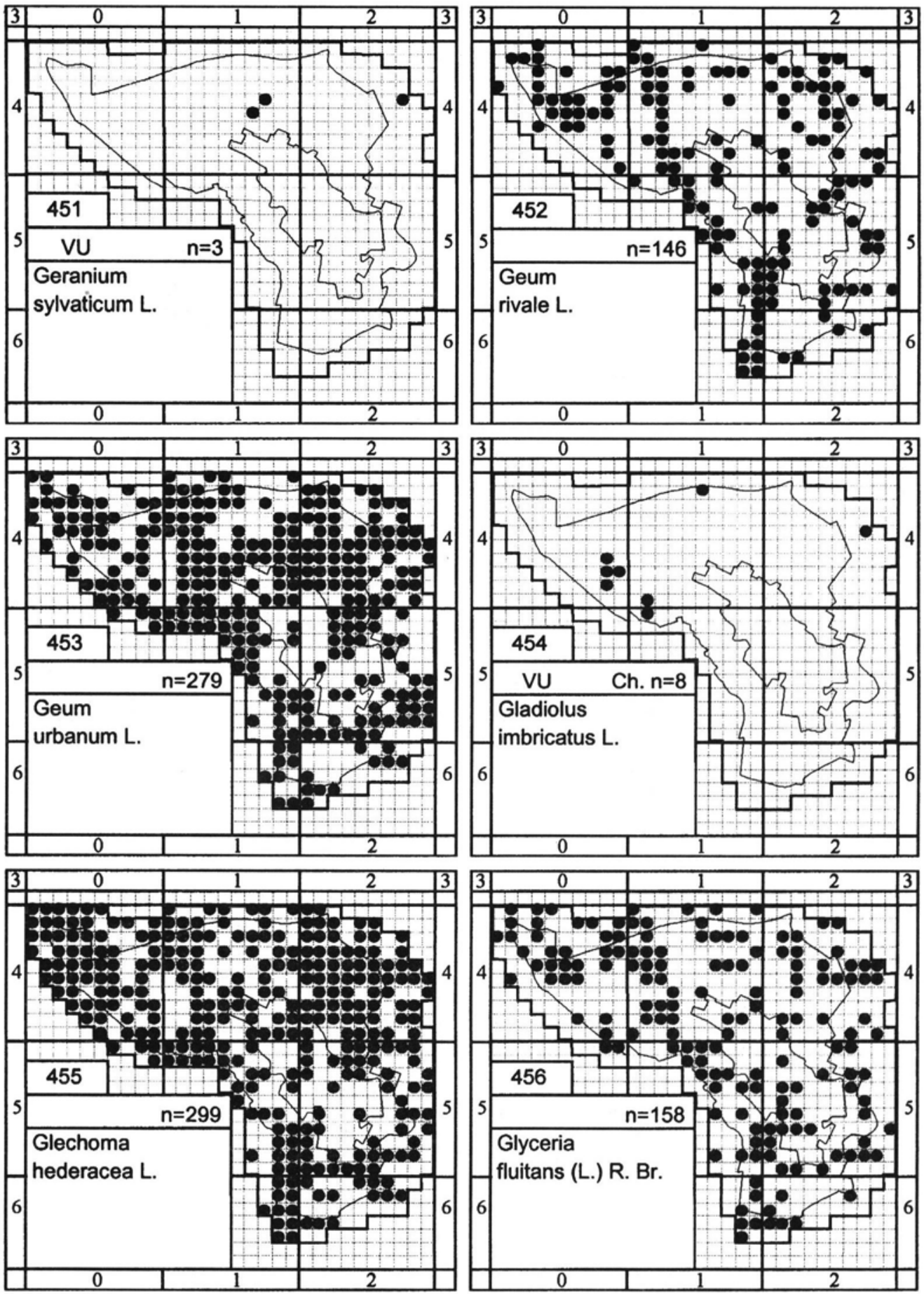

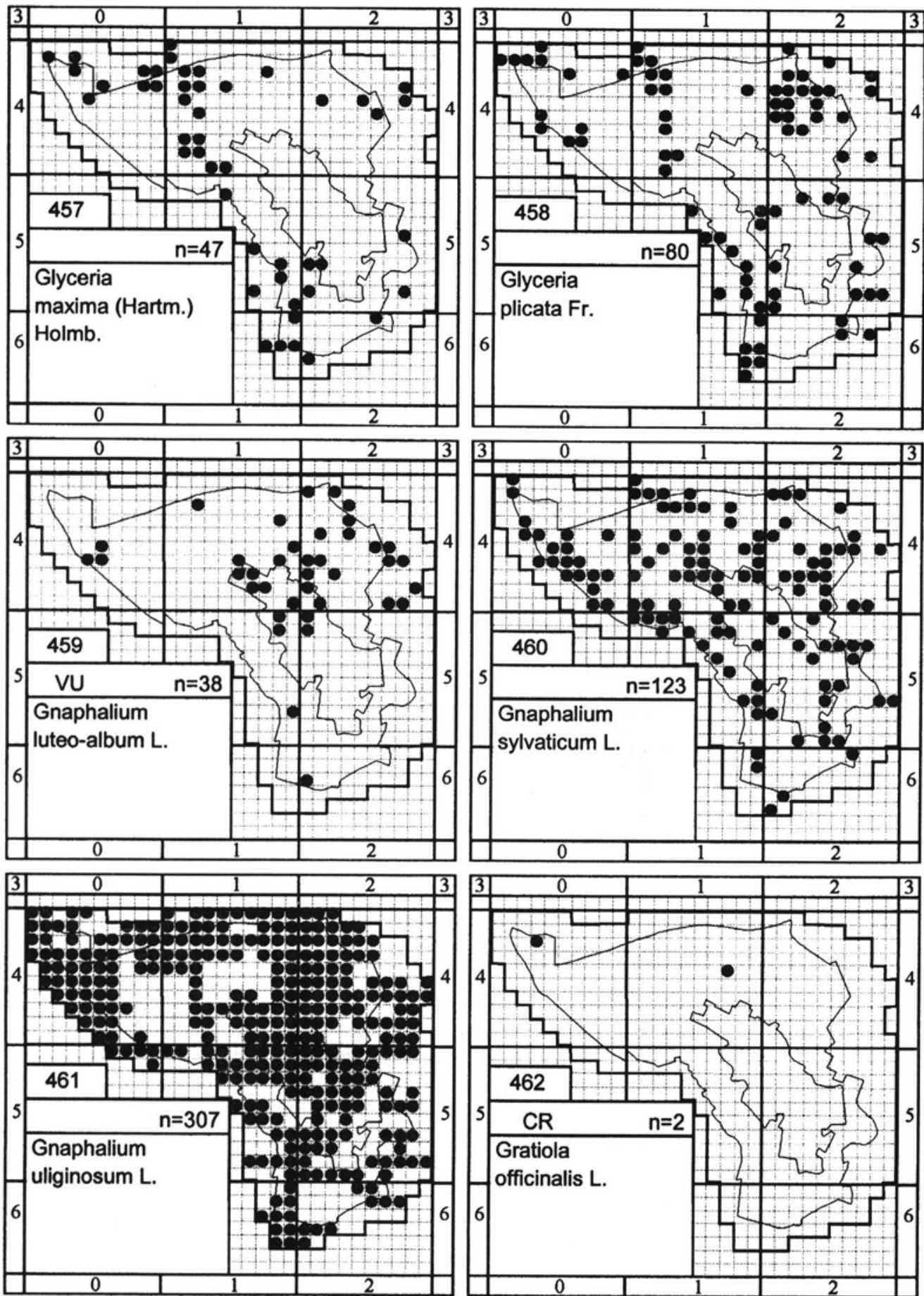

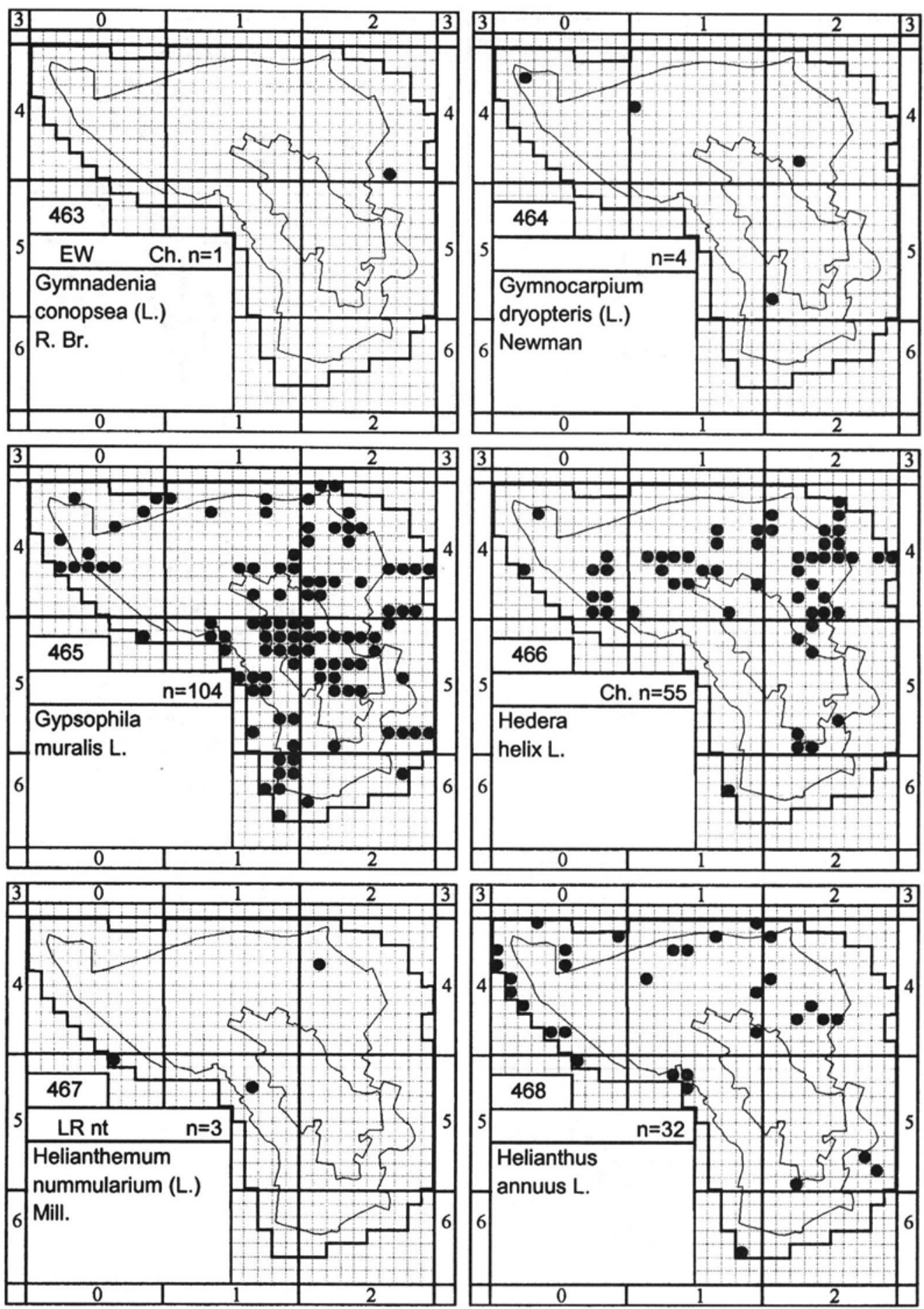


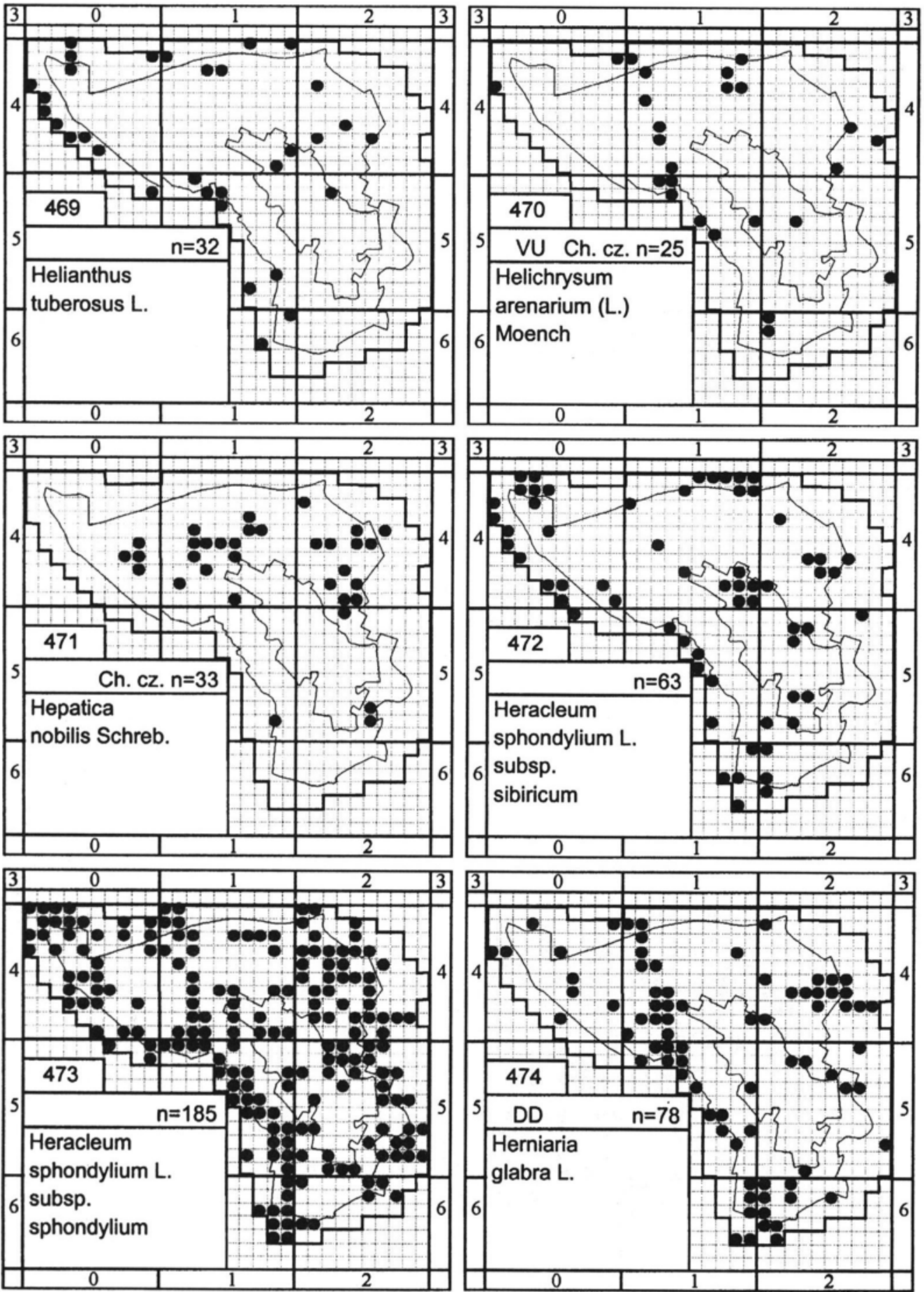



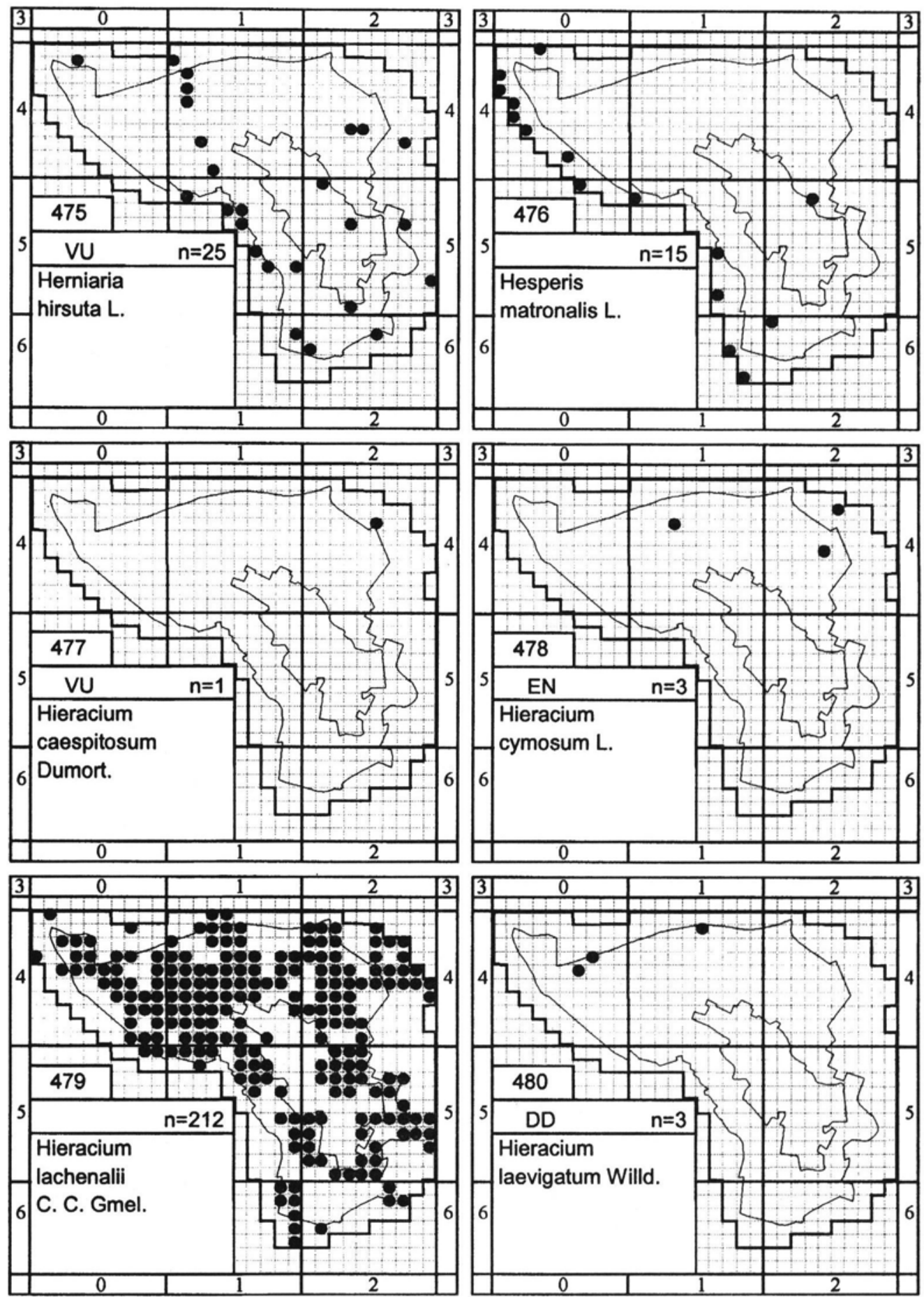


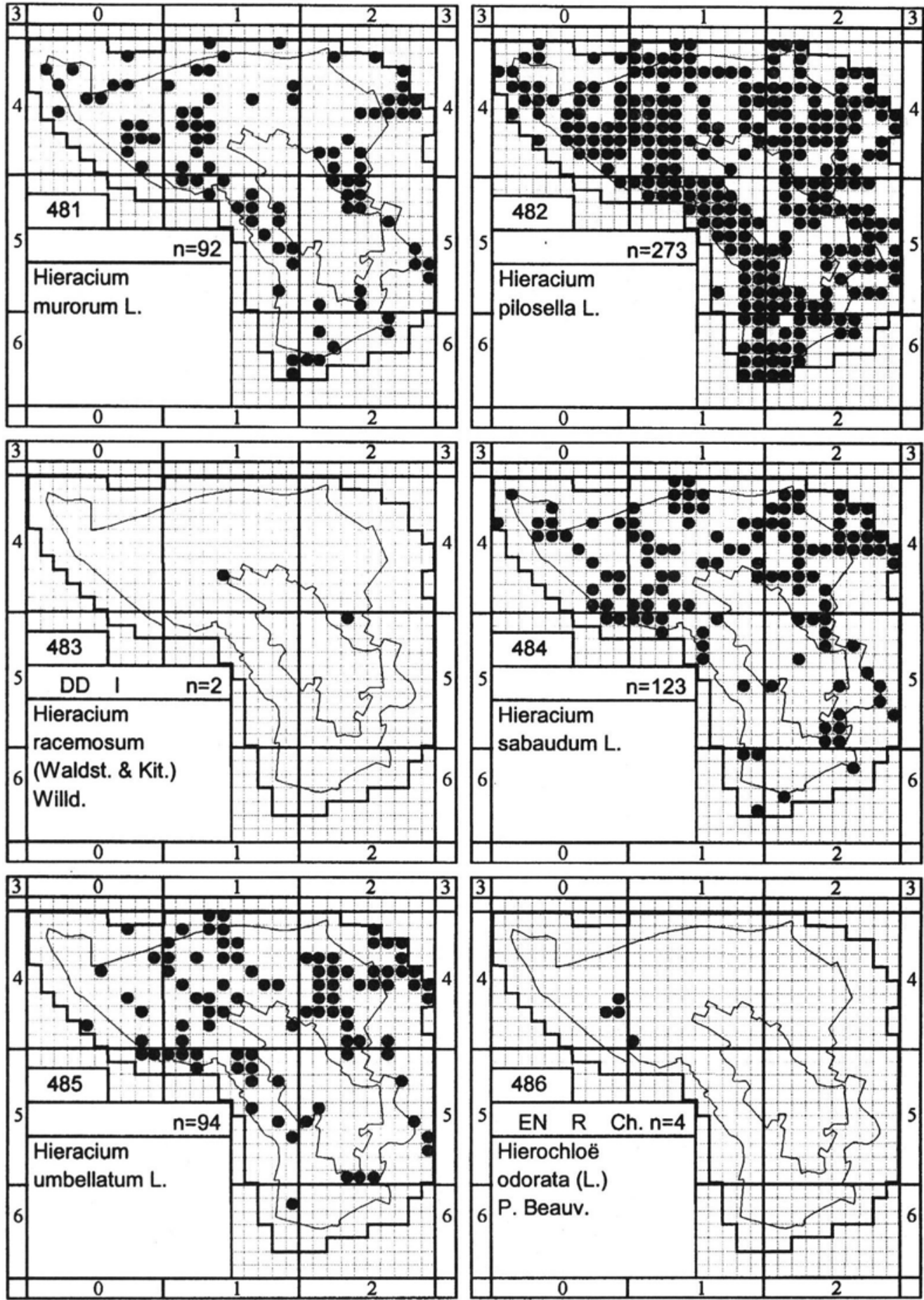



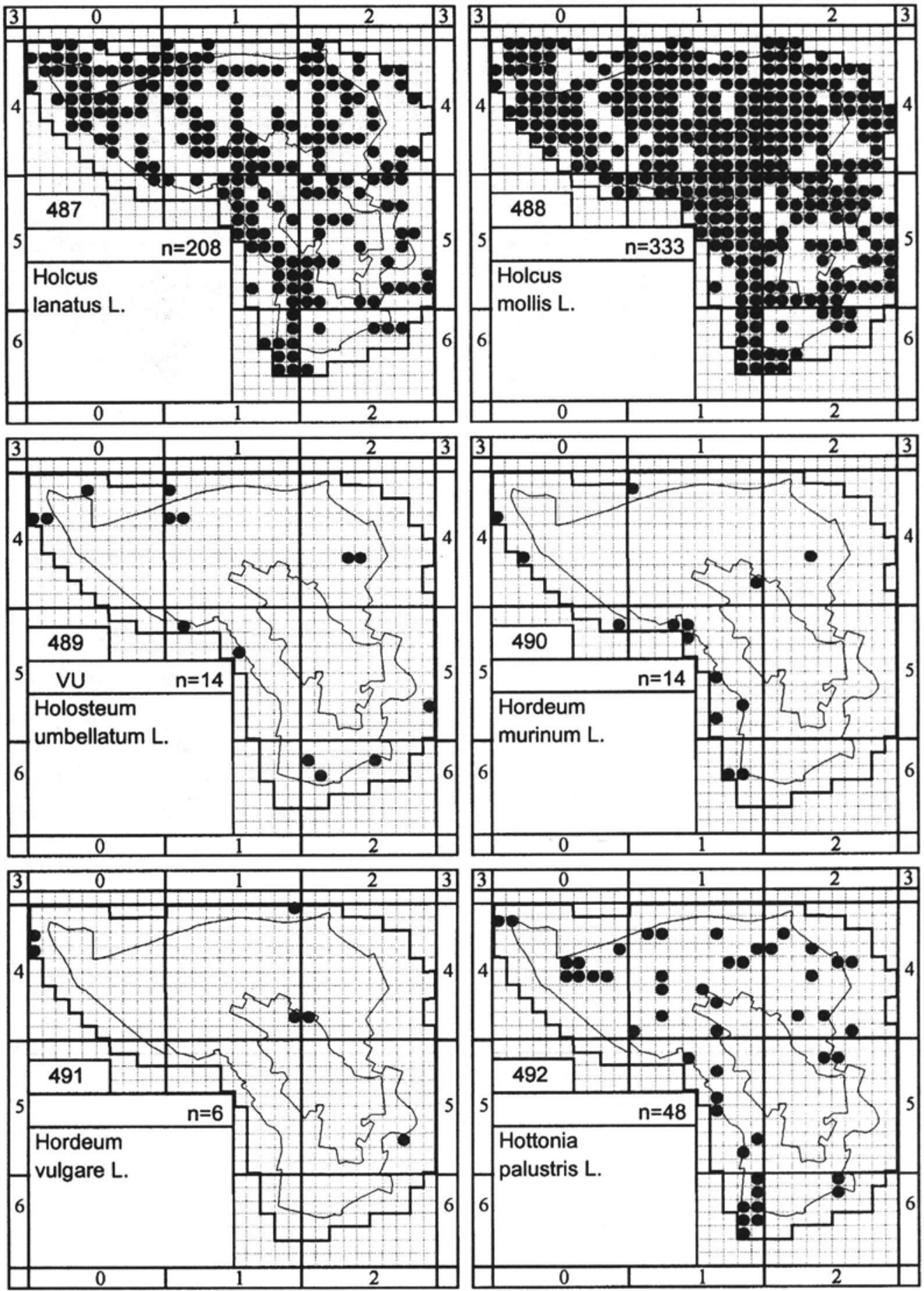

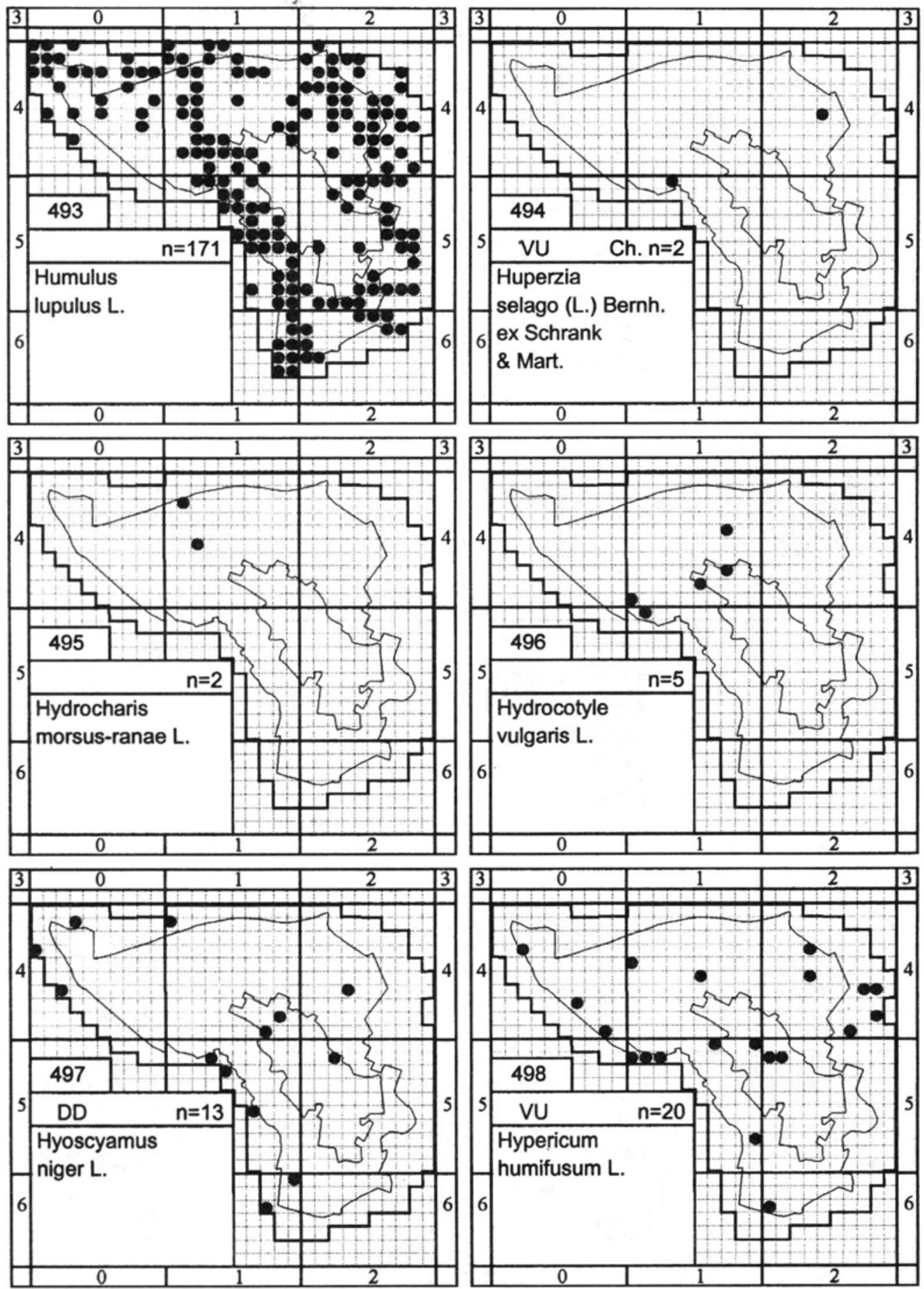

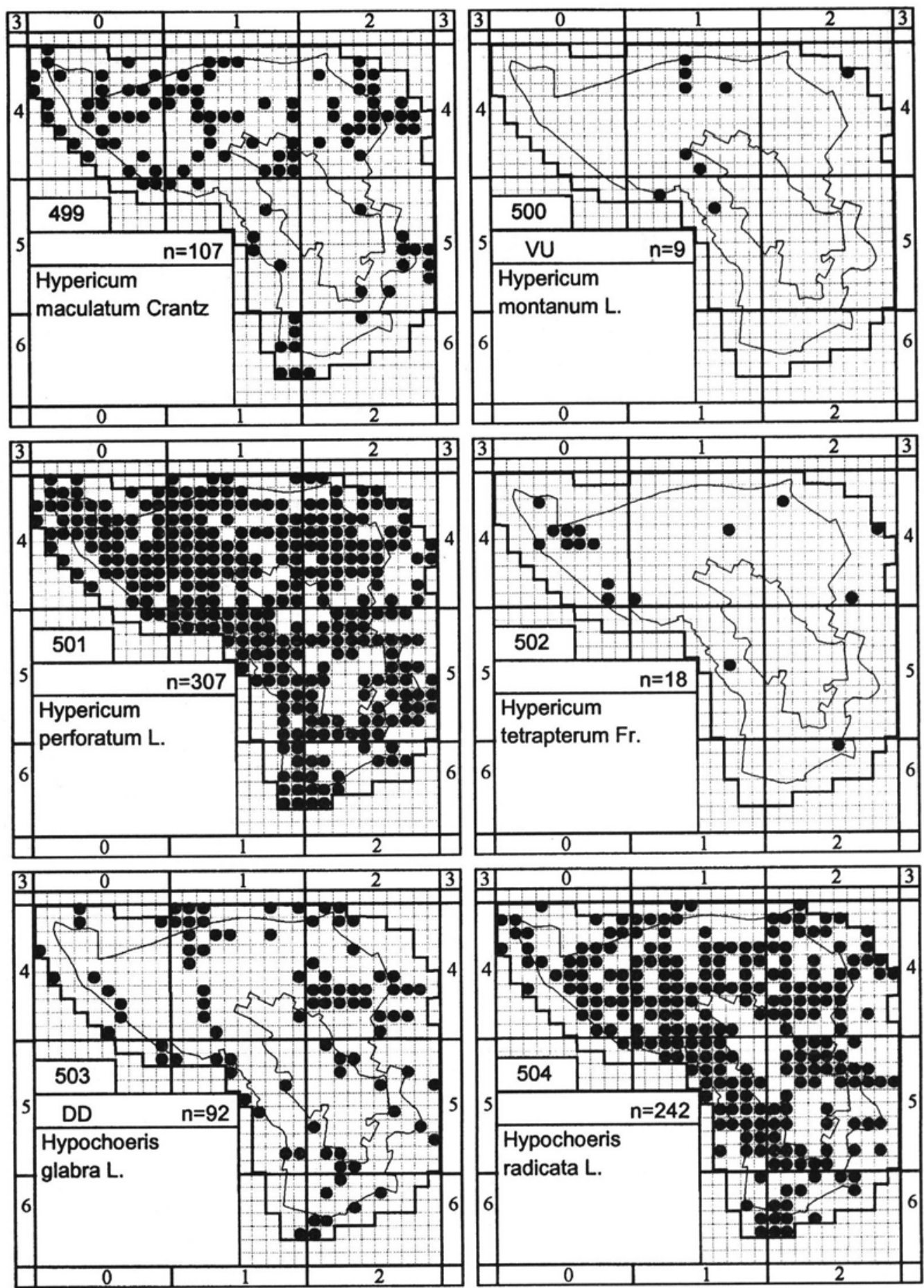

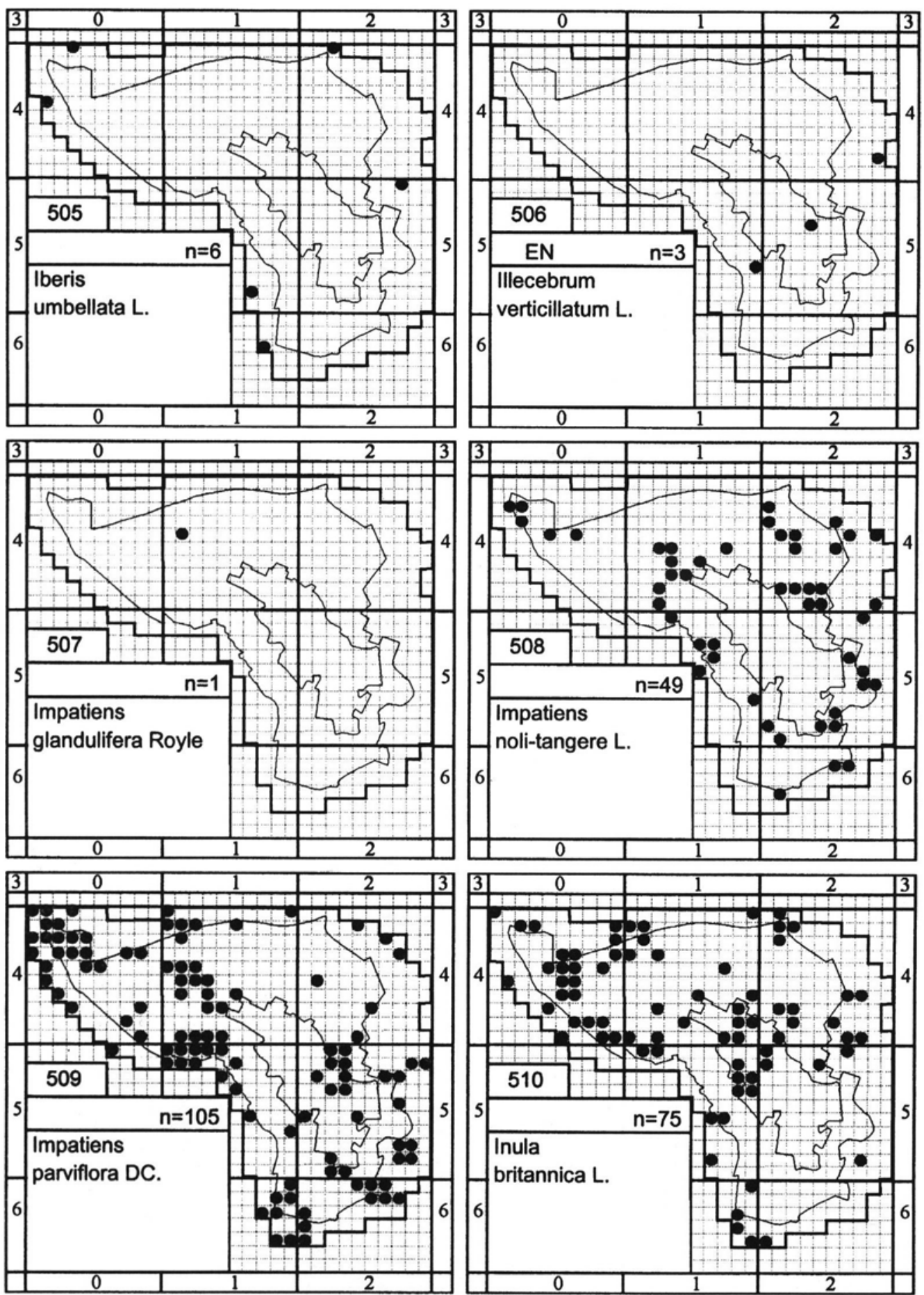


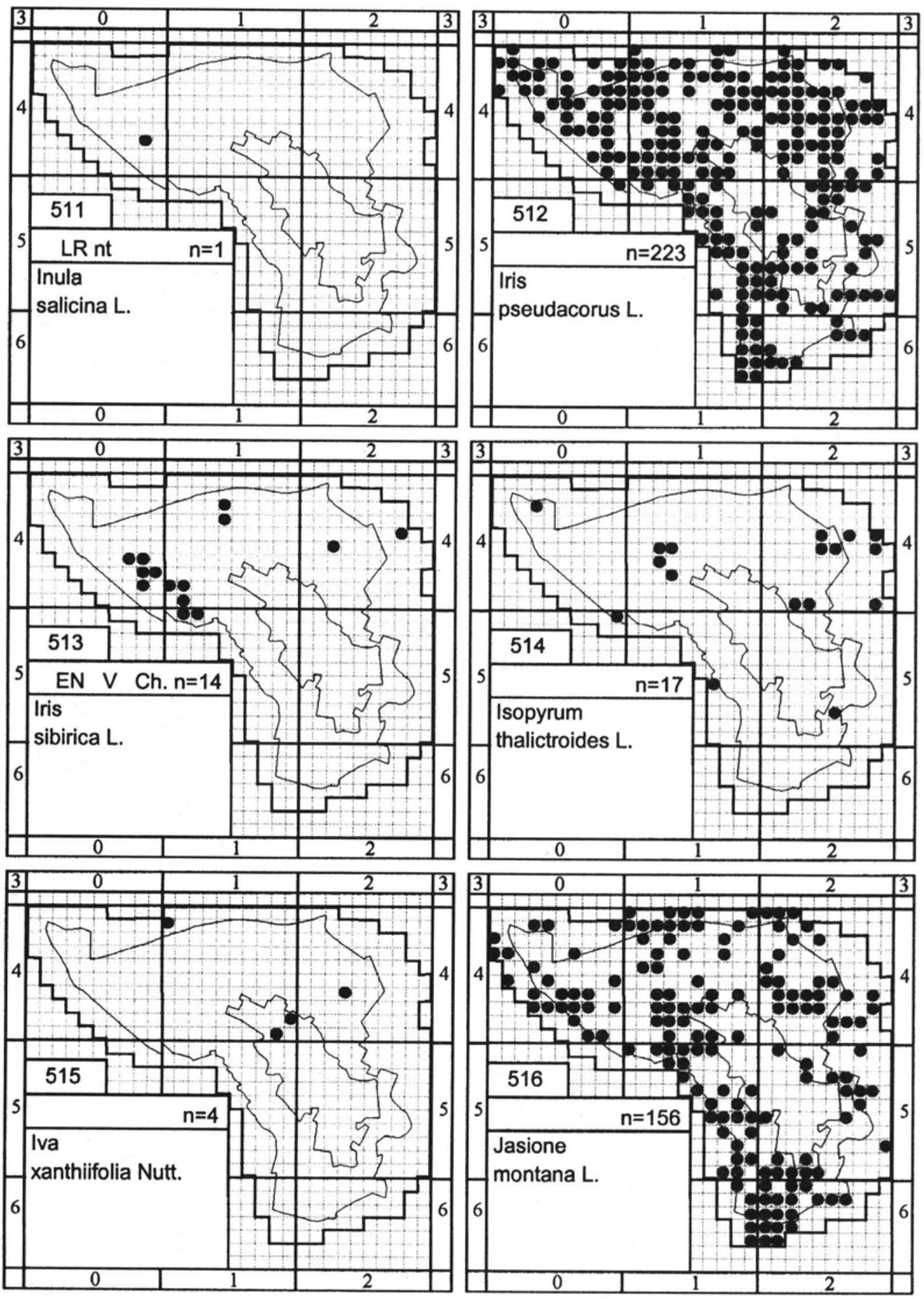




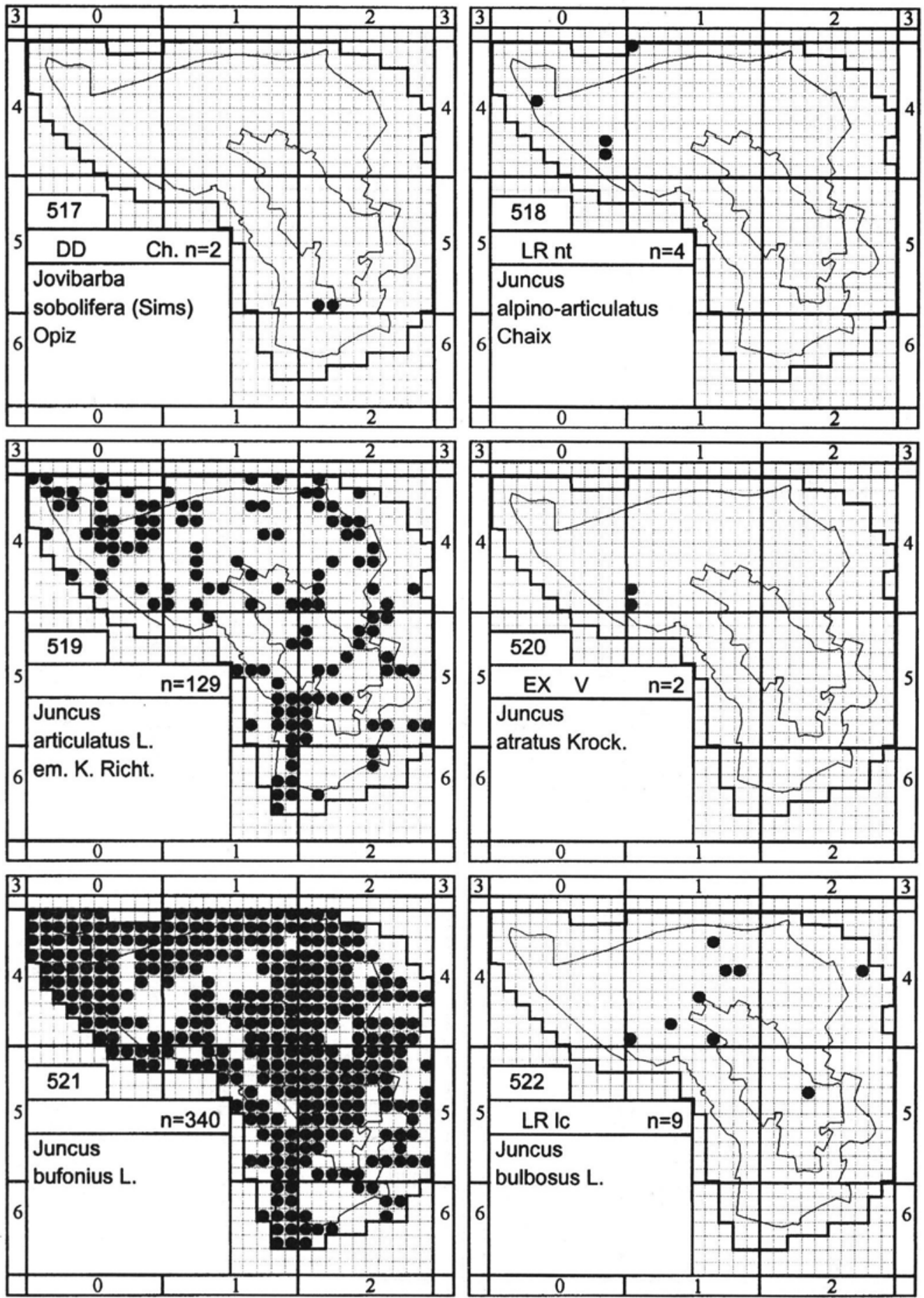



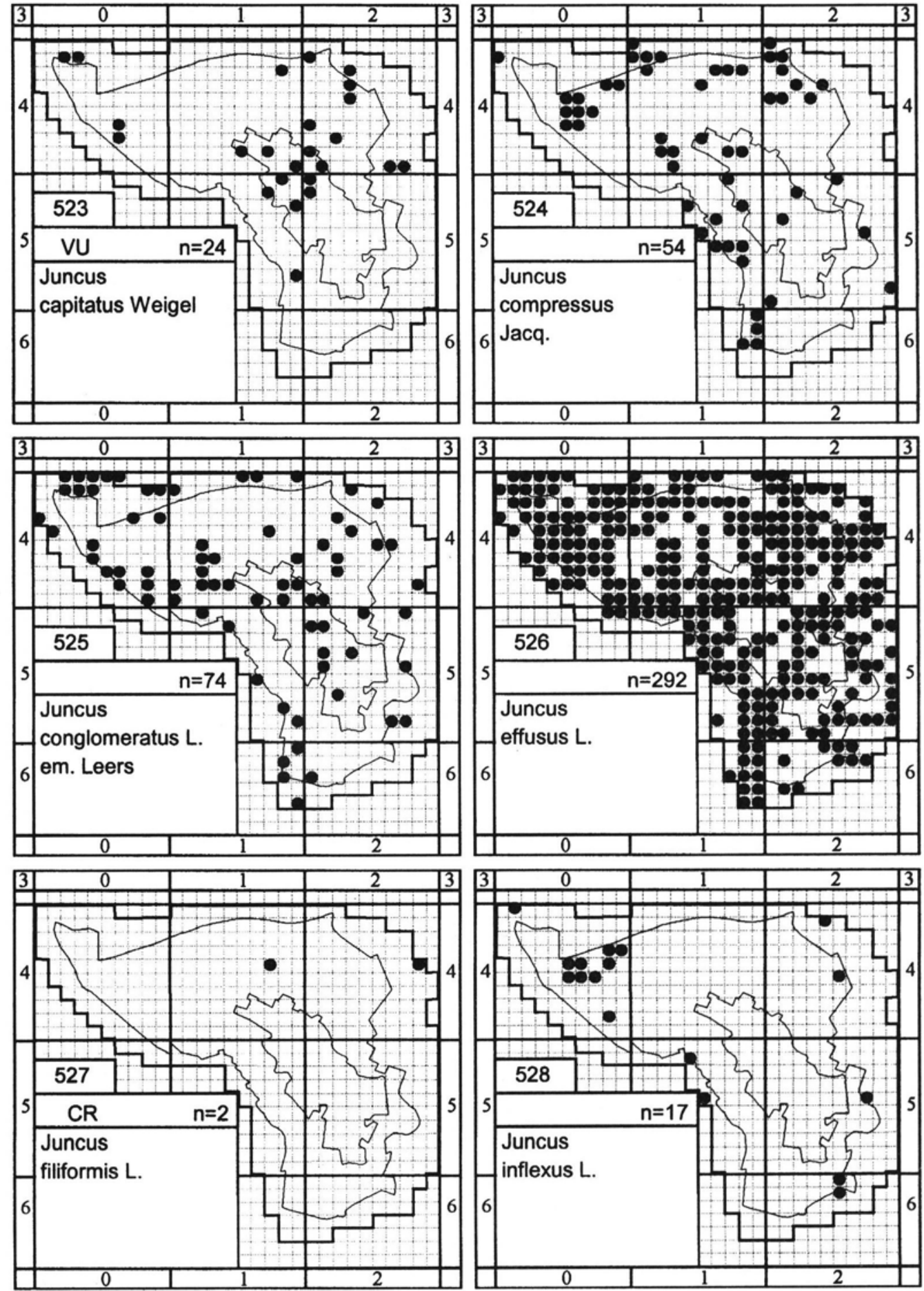

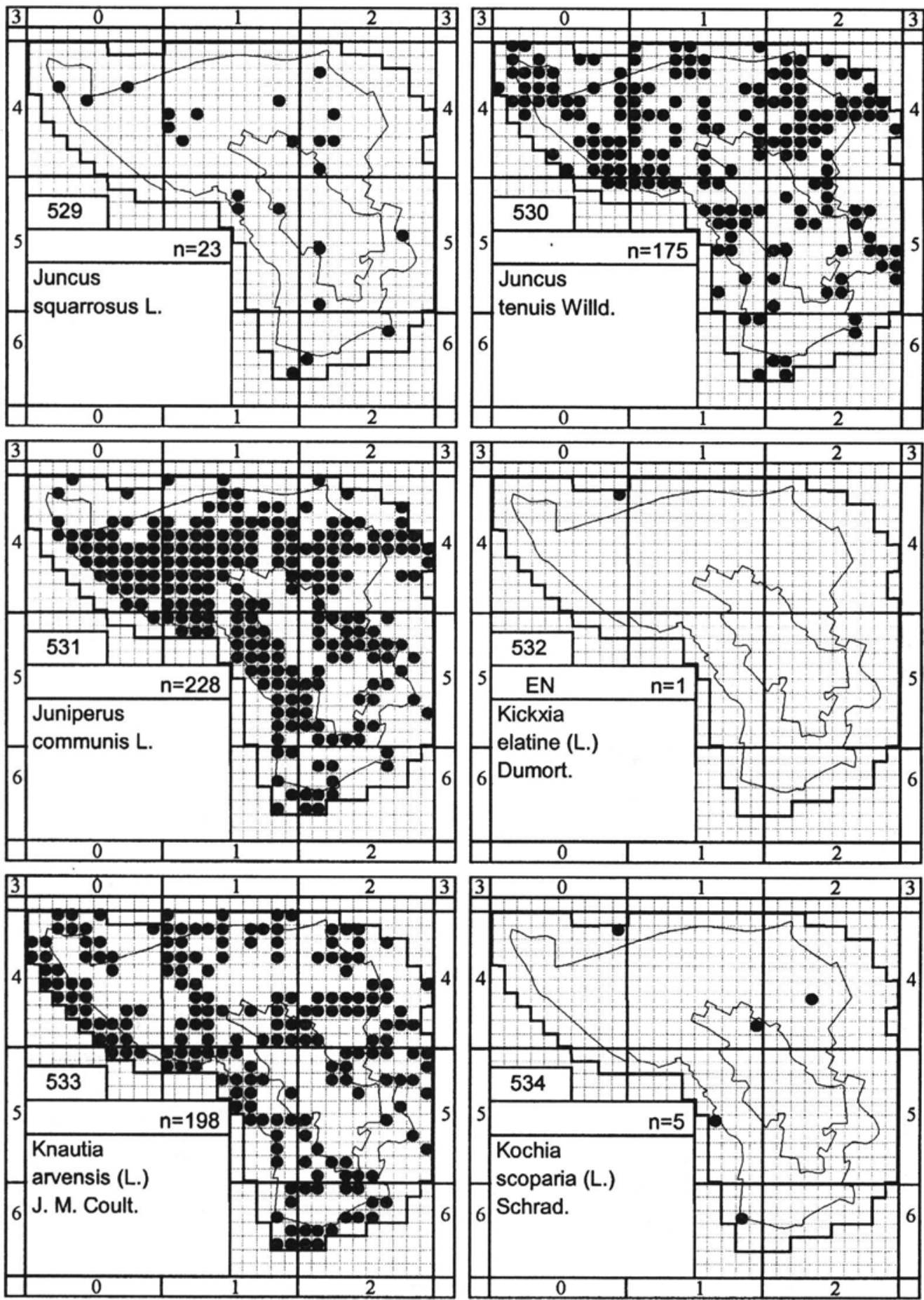

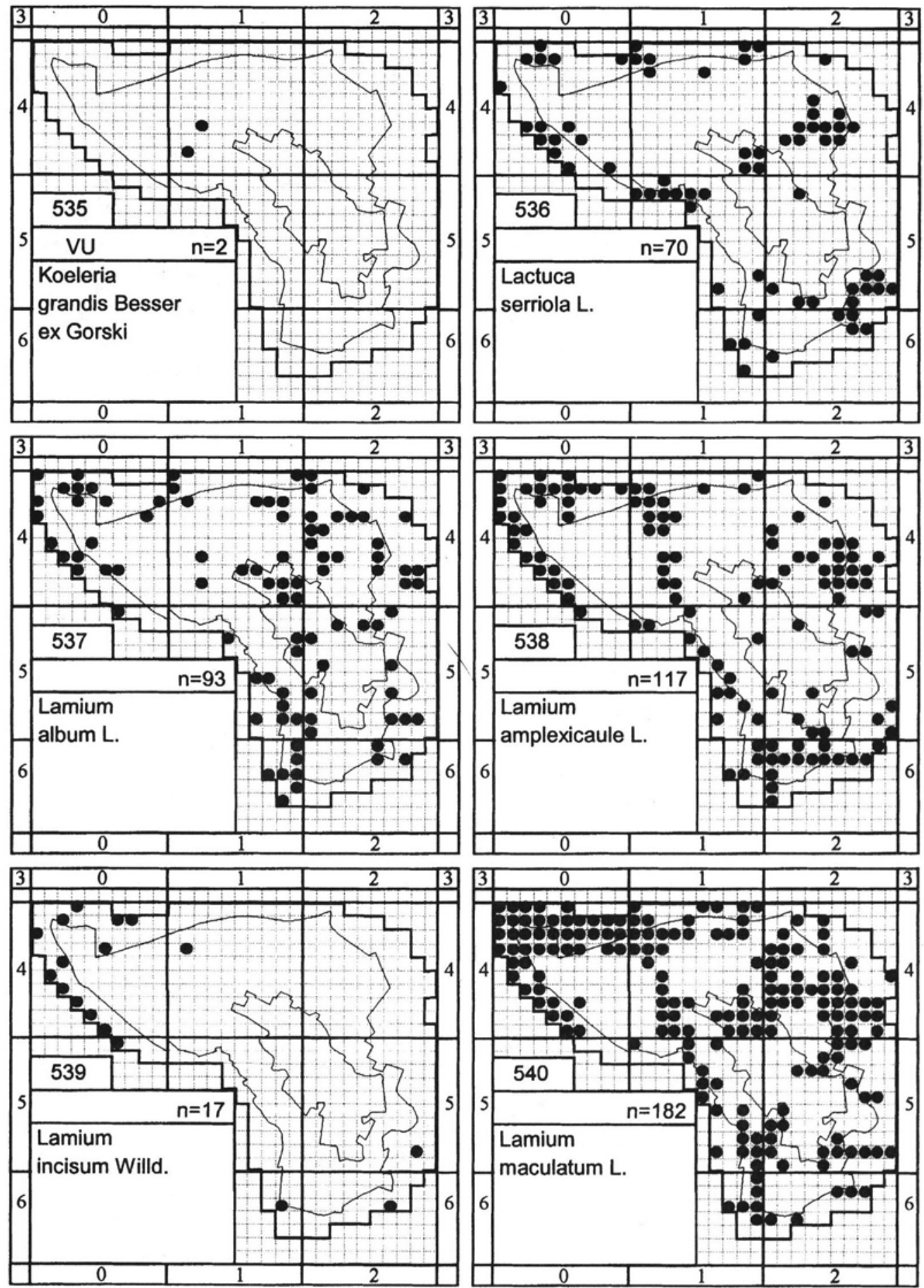

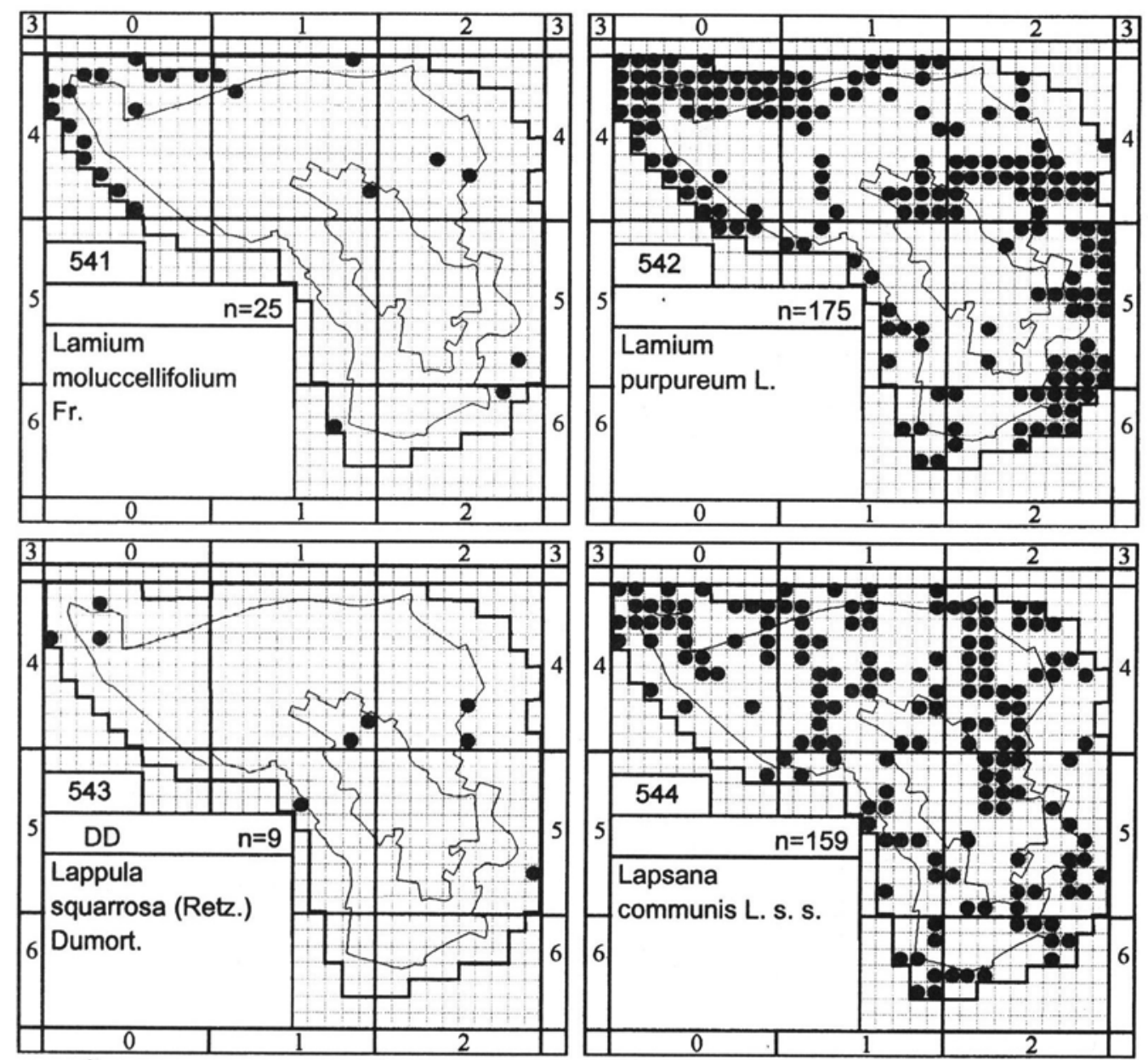

\begin{tabular}{|}
\hline 3 \\
\hline
\end{tabular}
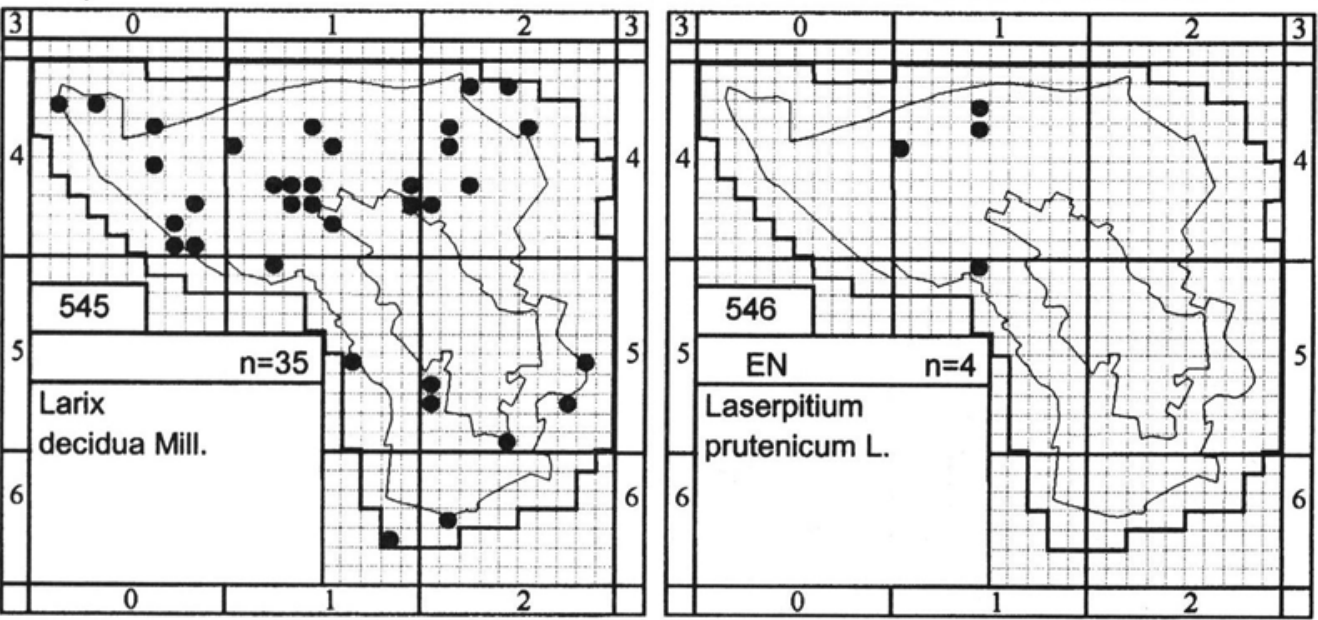

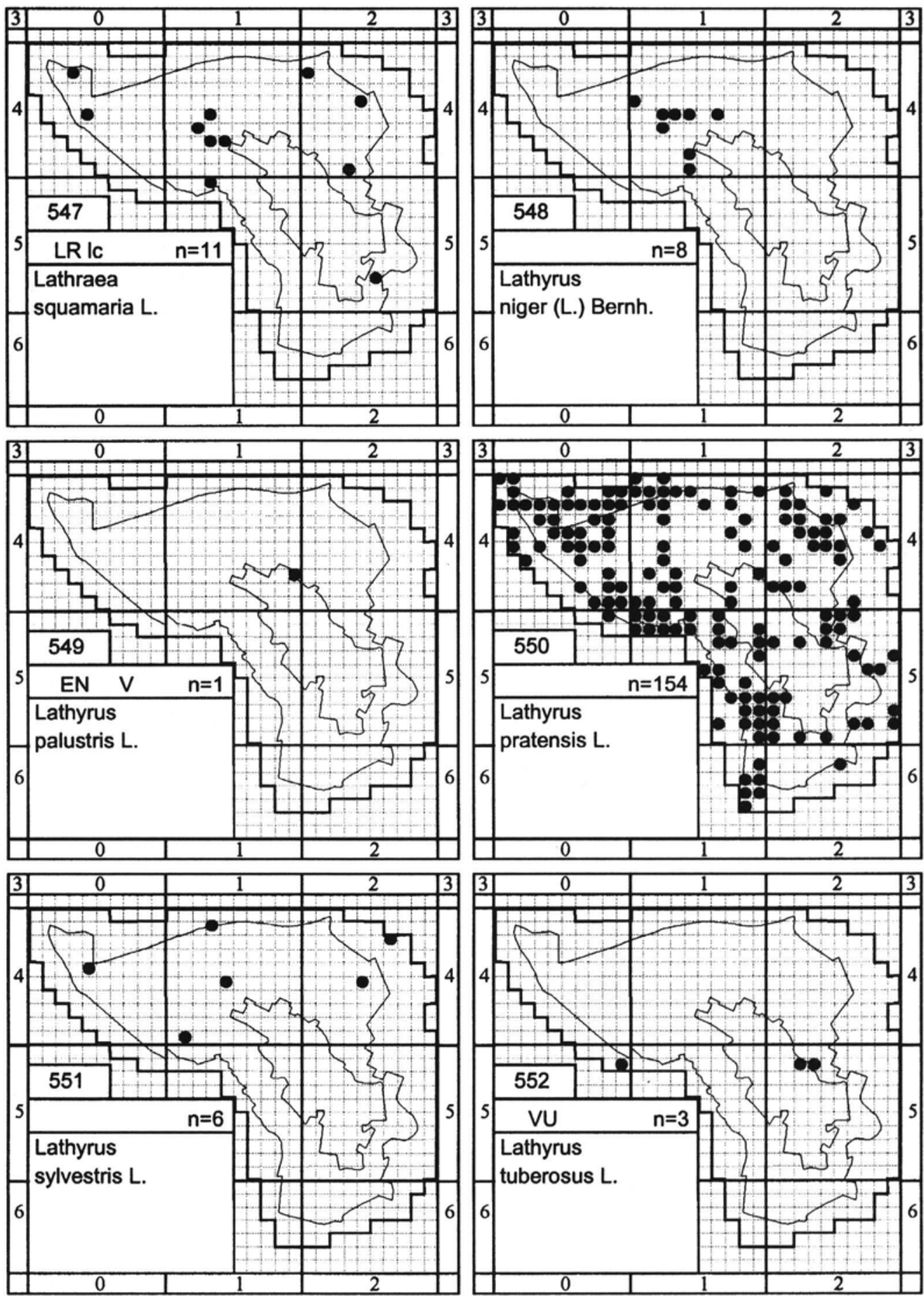

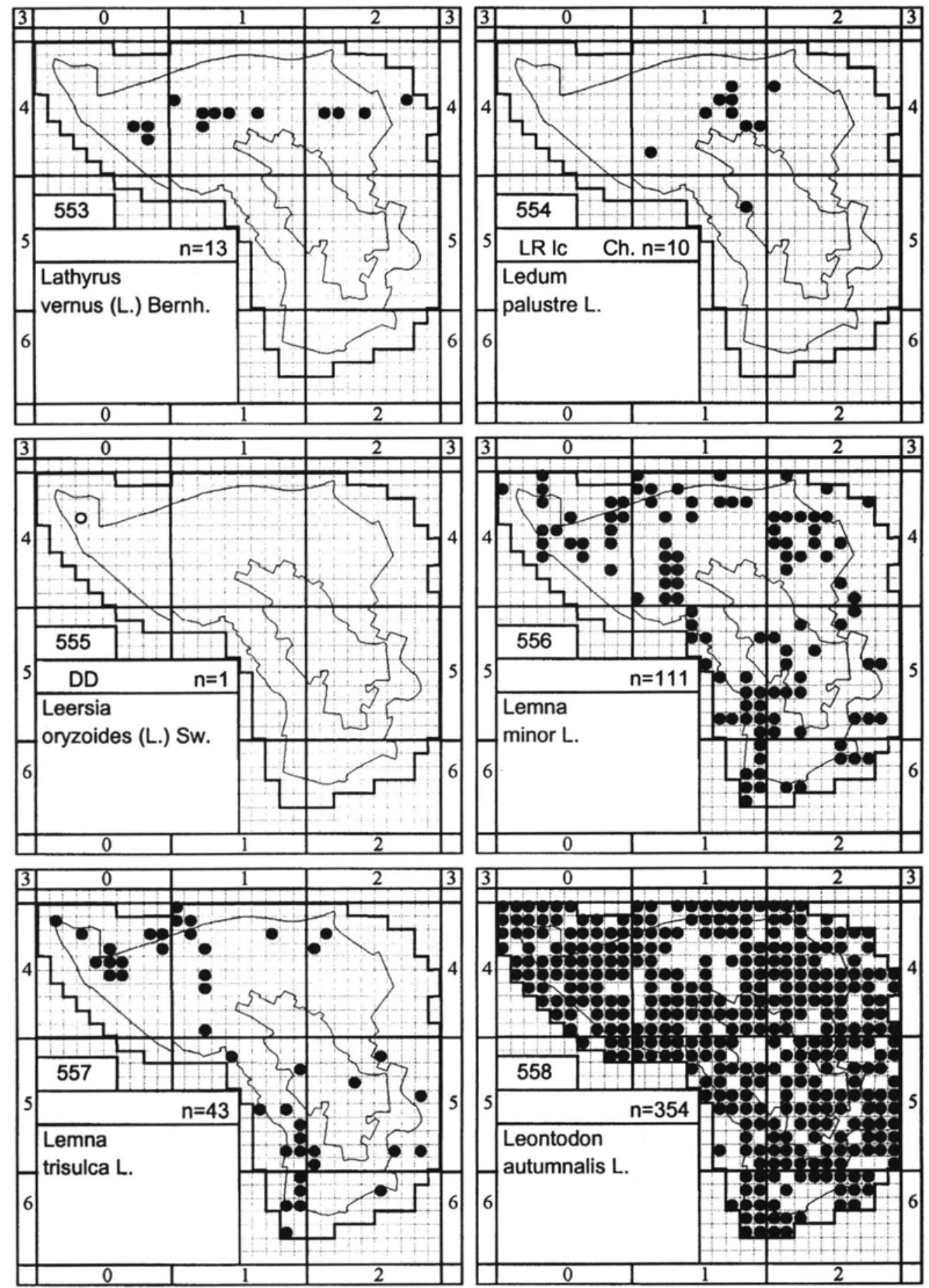


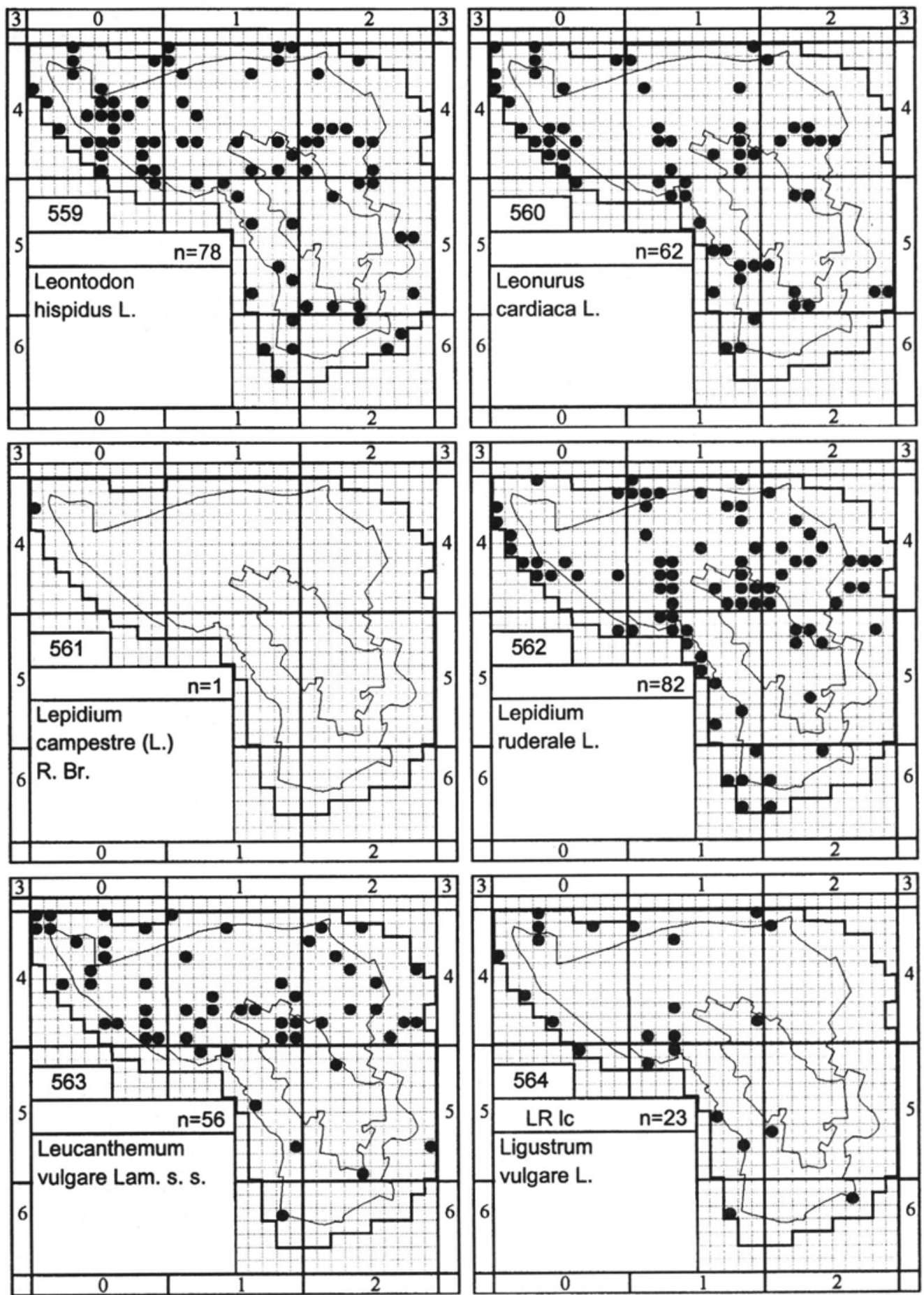



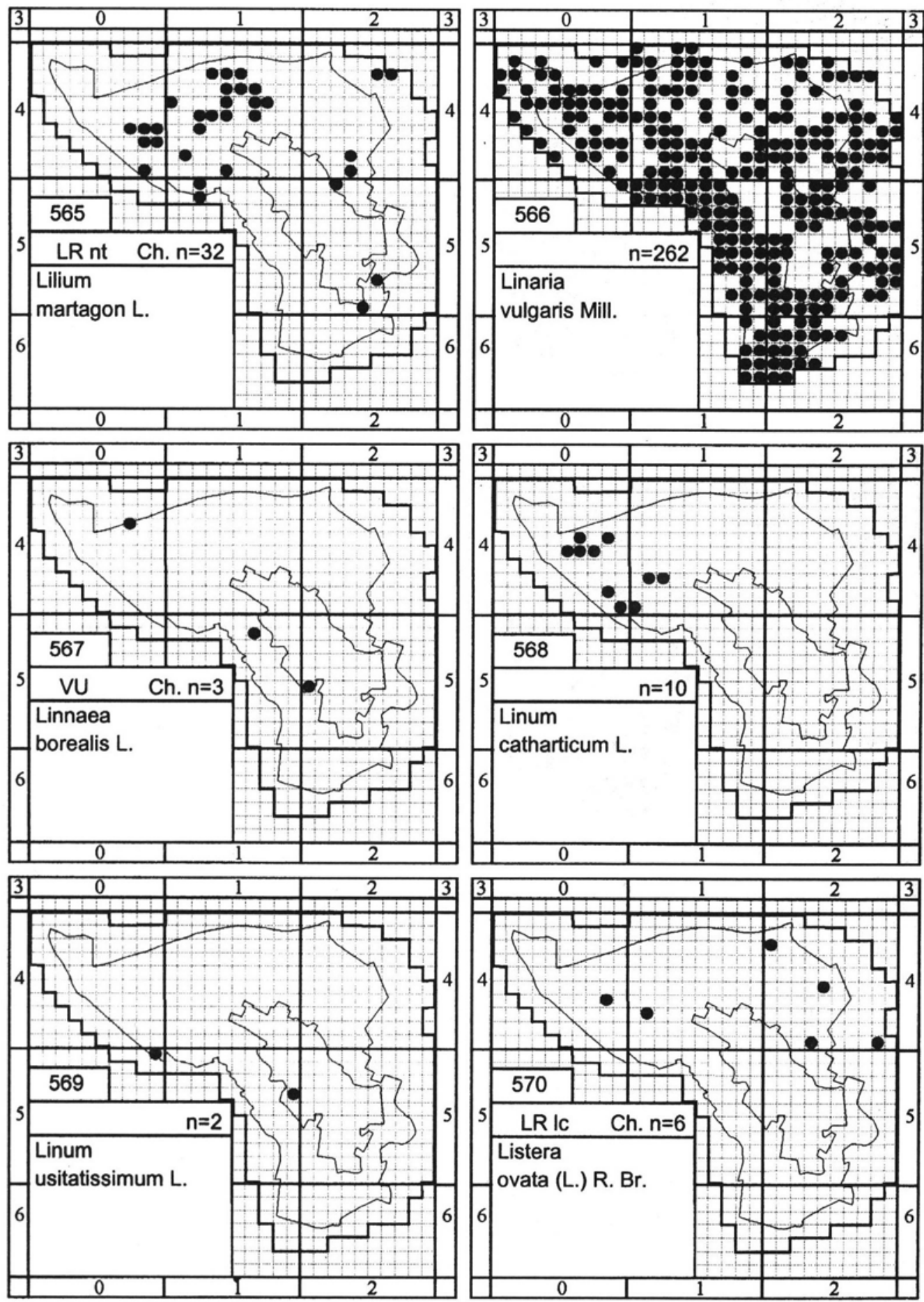

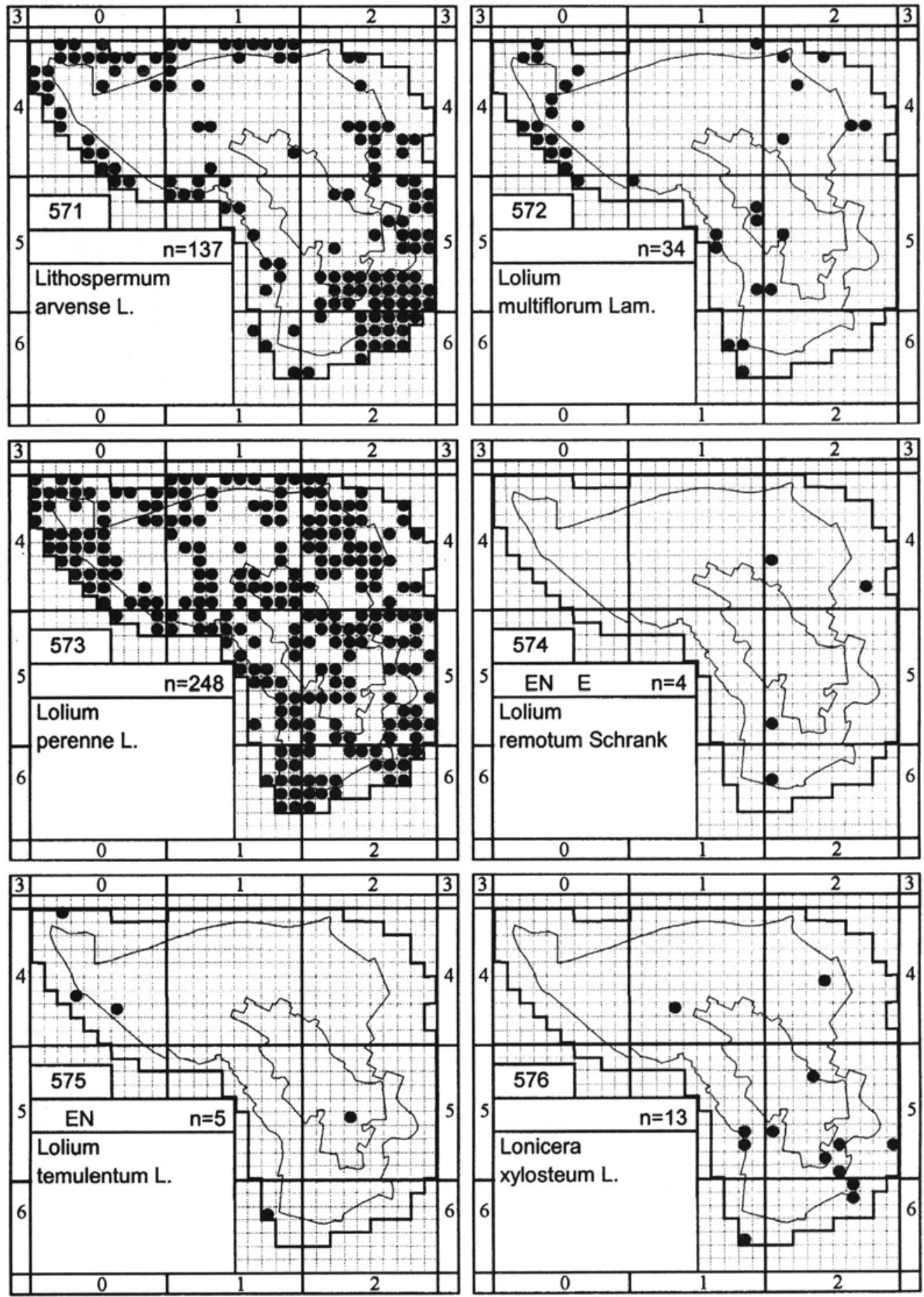


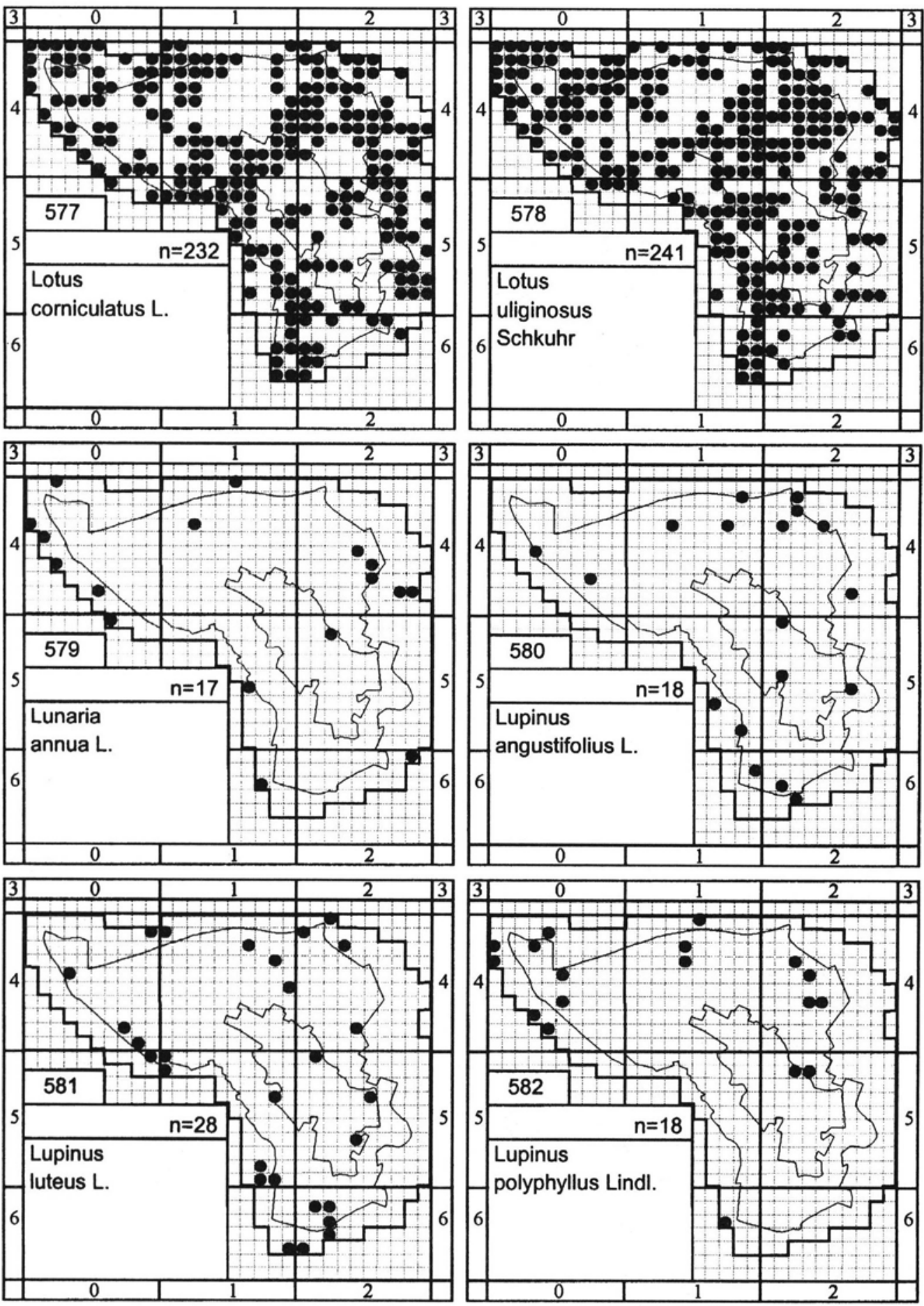



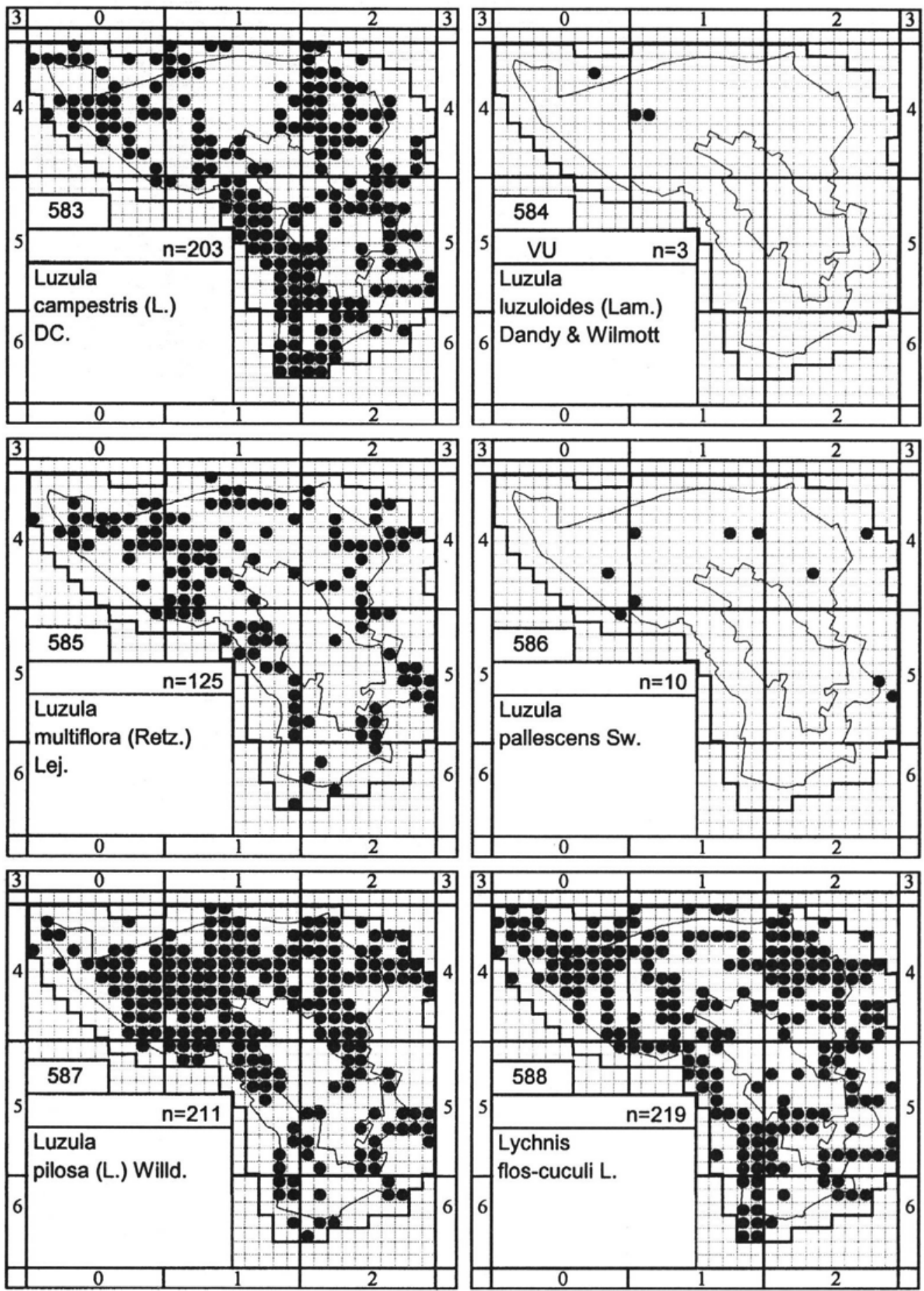

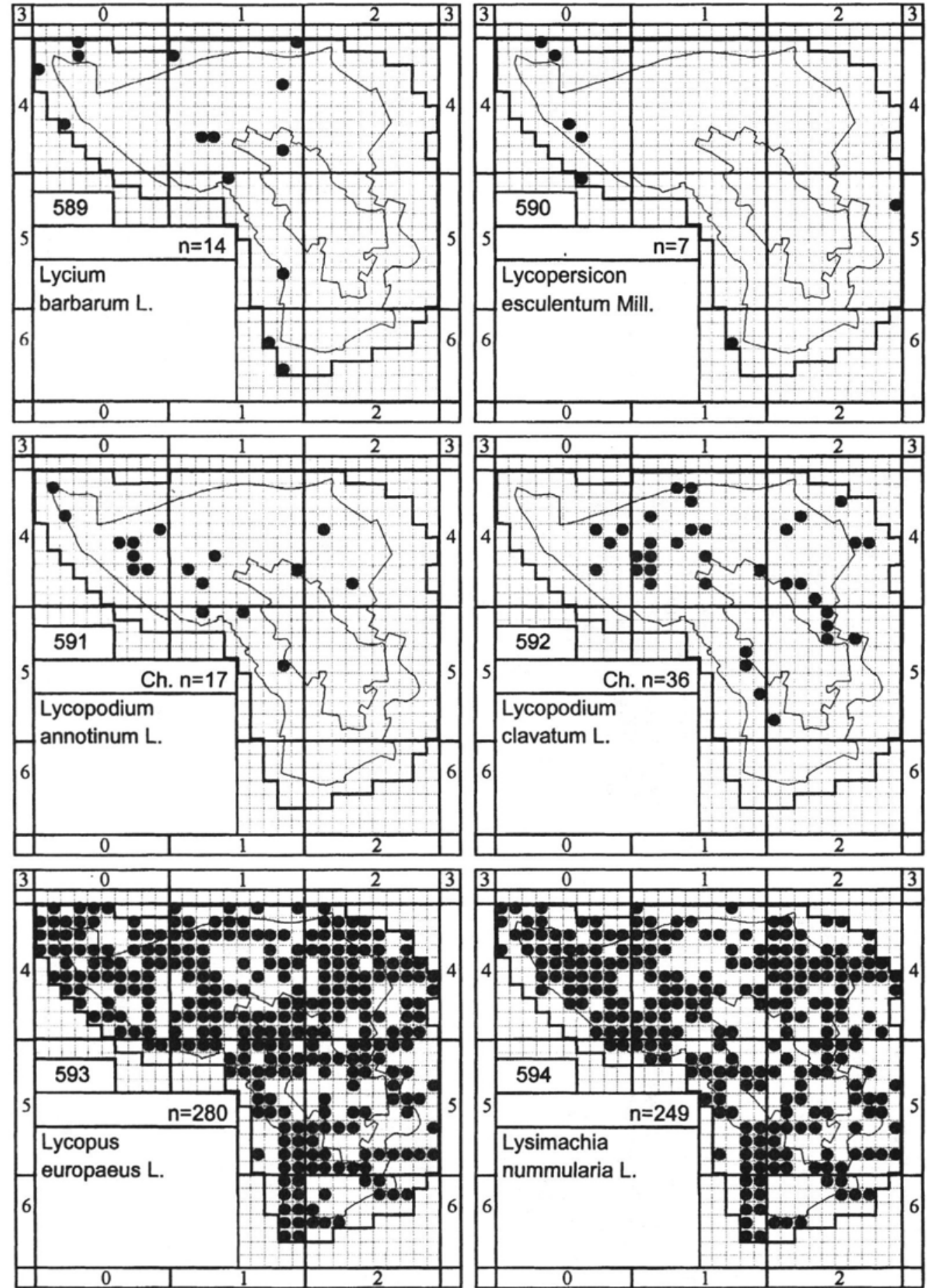

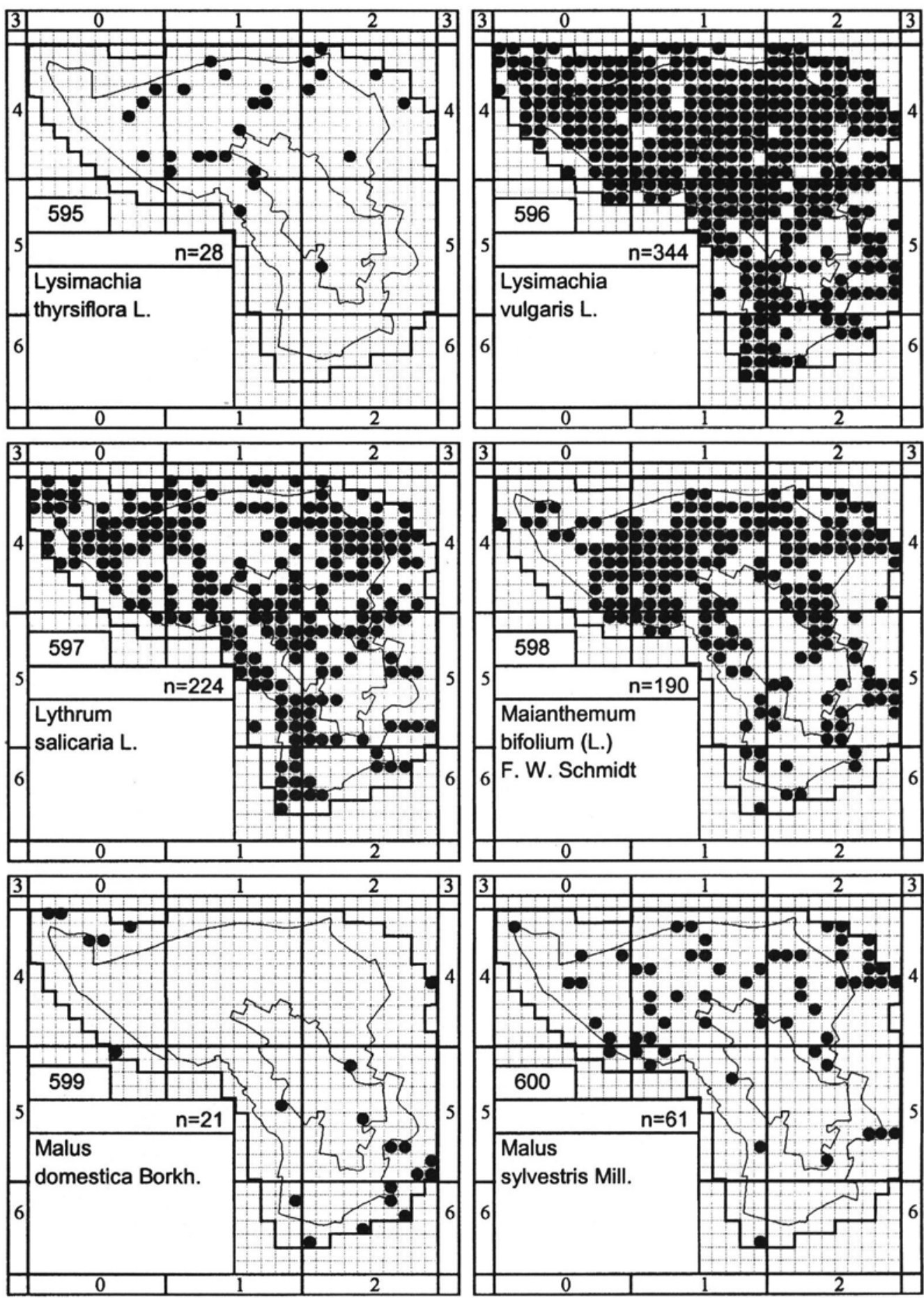

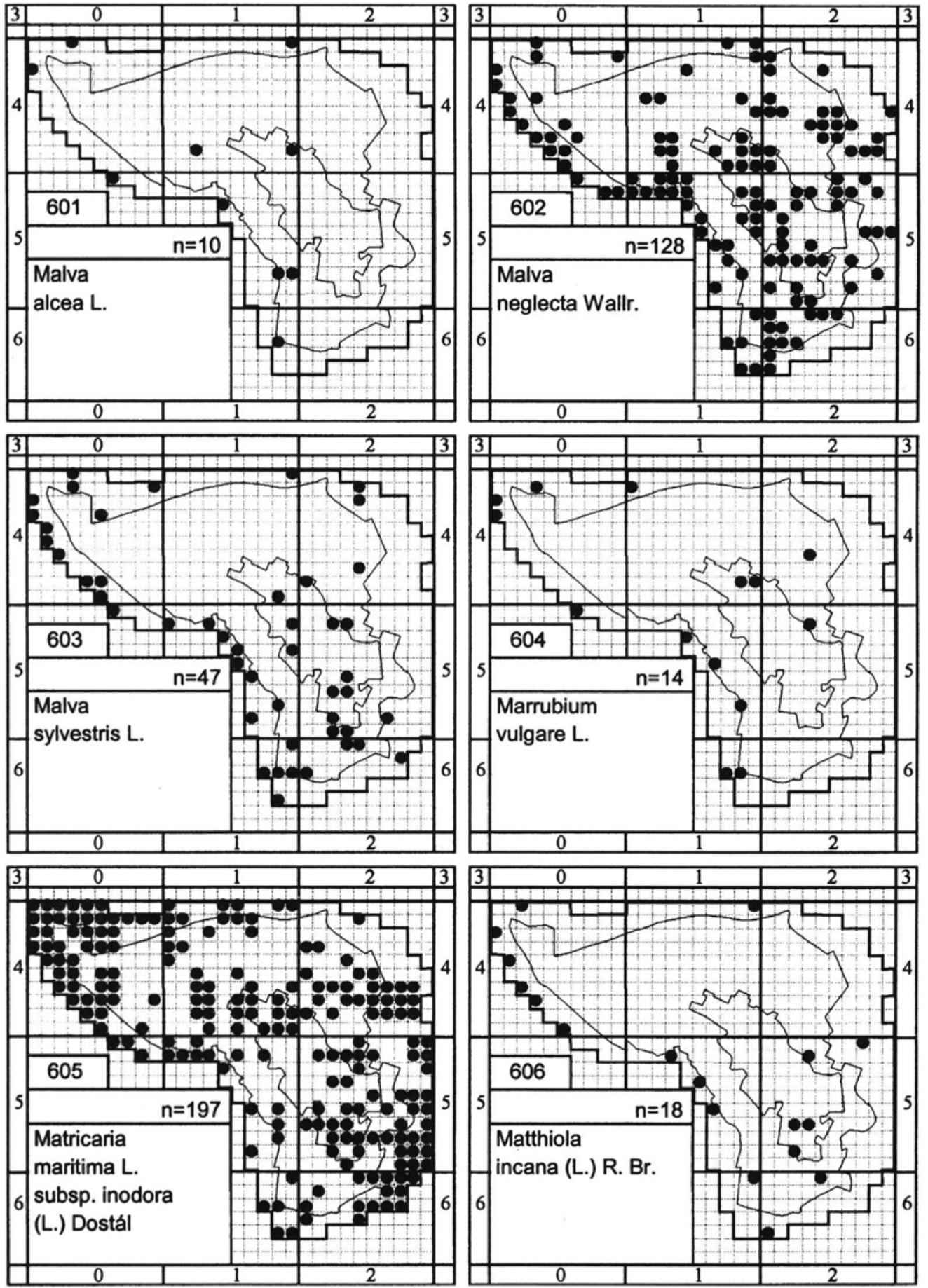


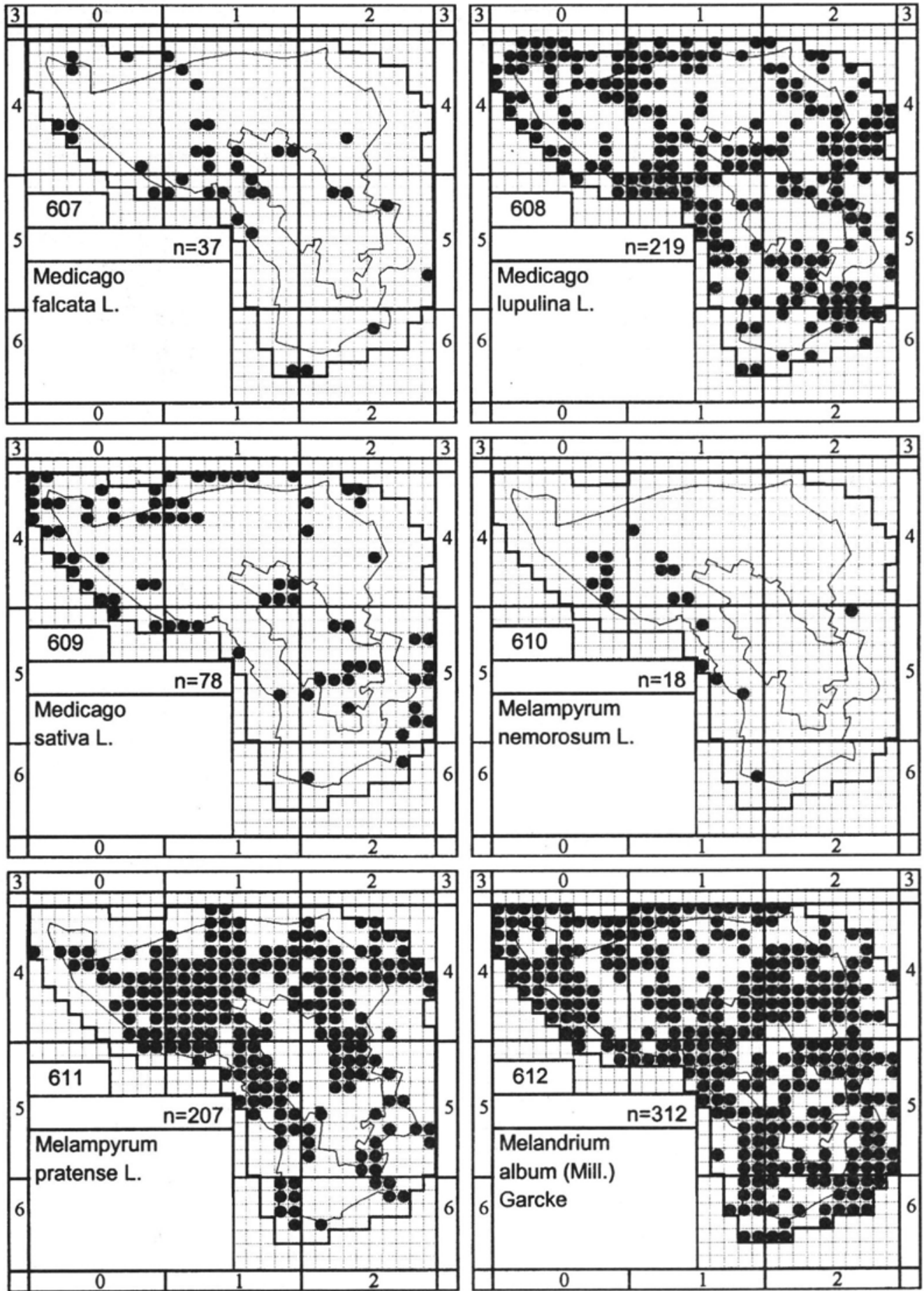



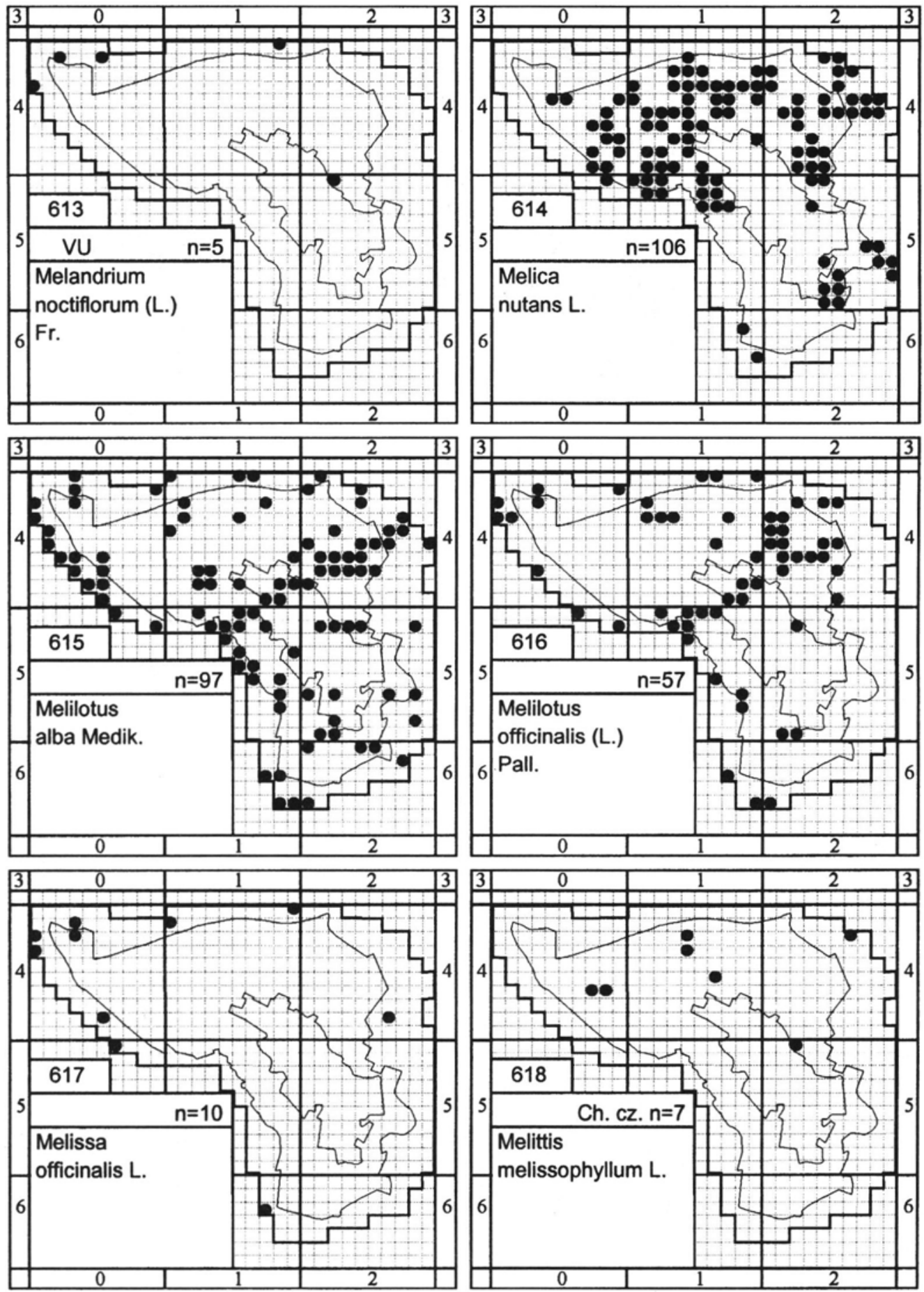

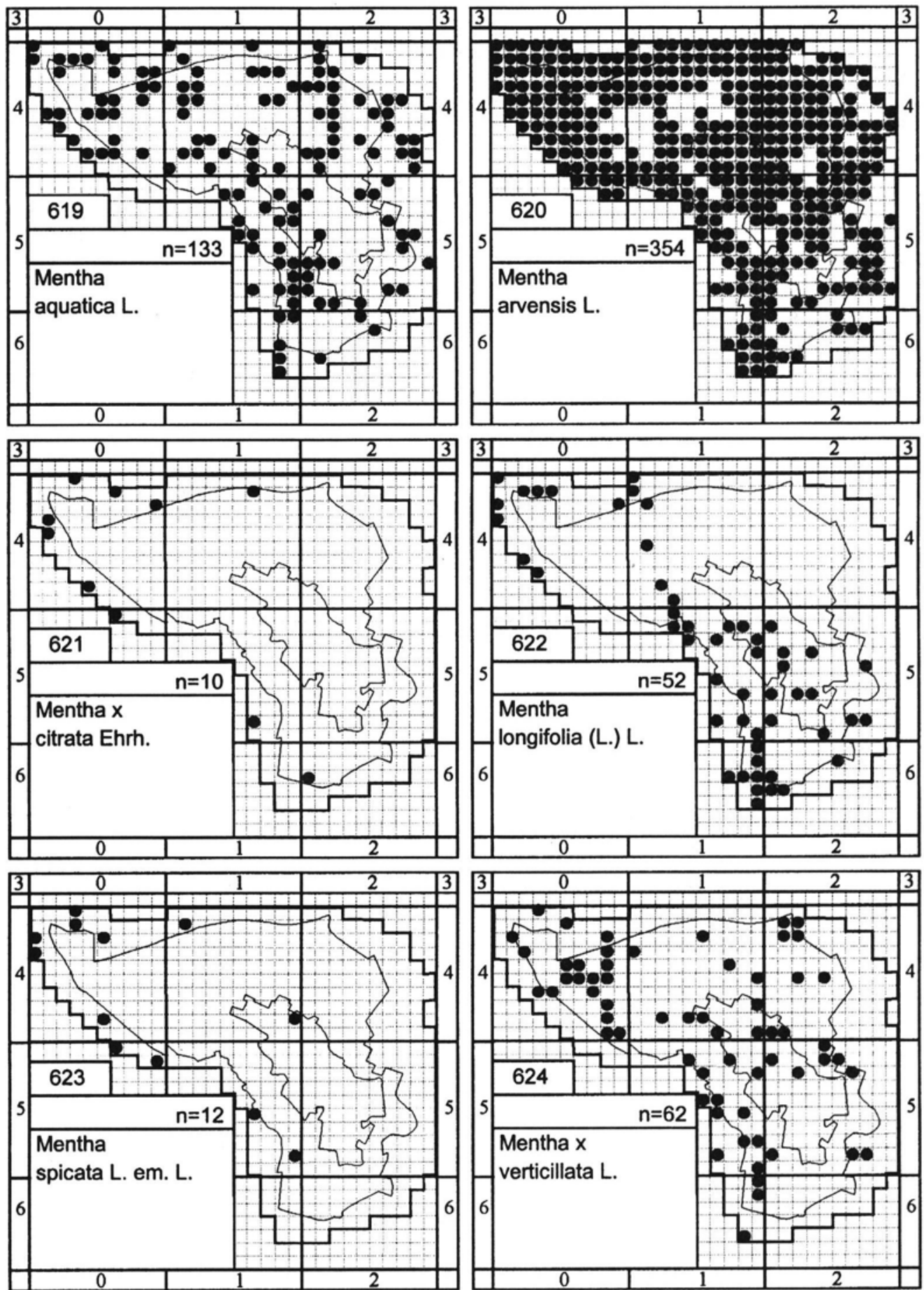


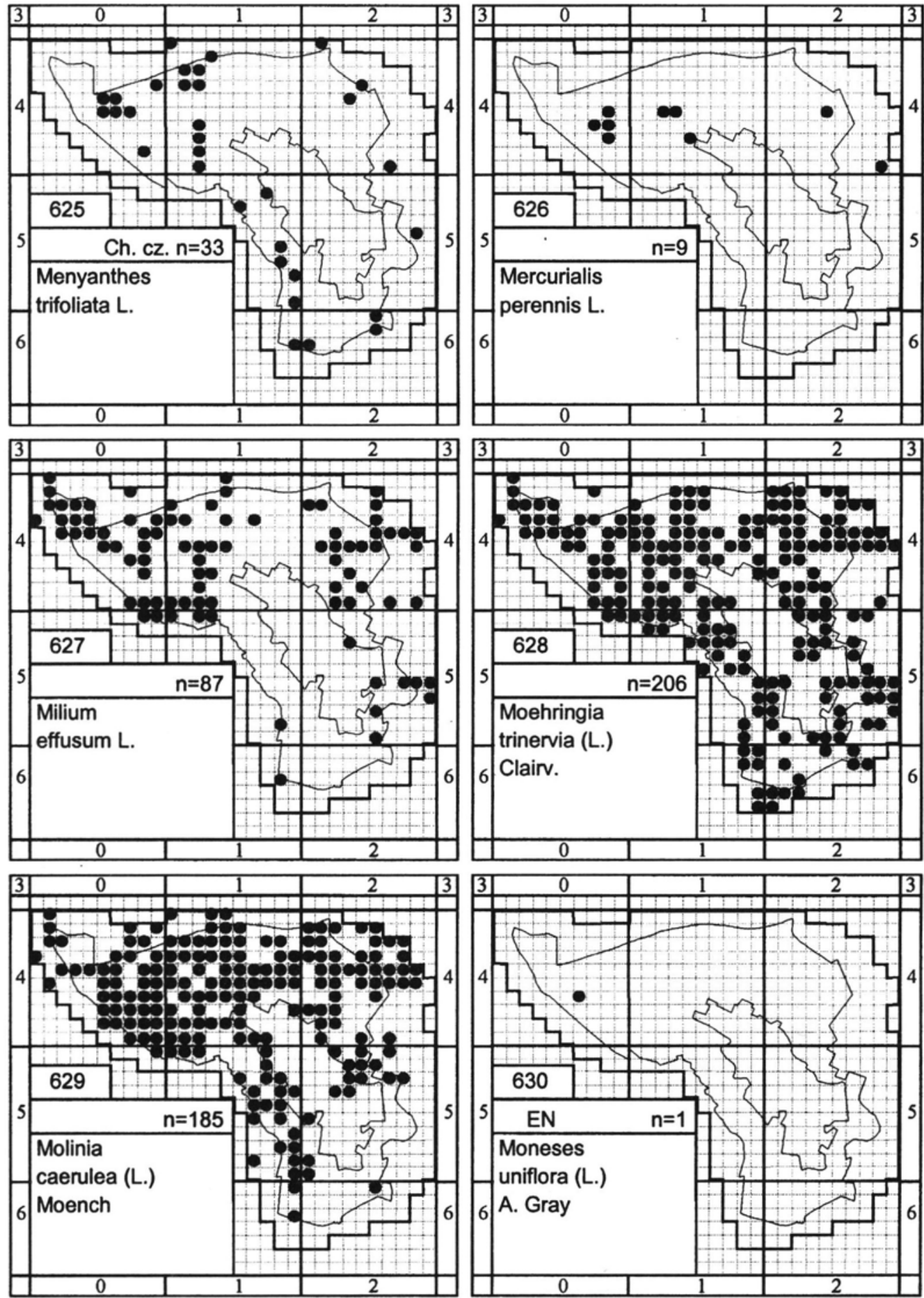




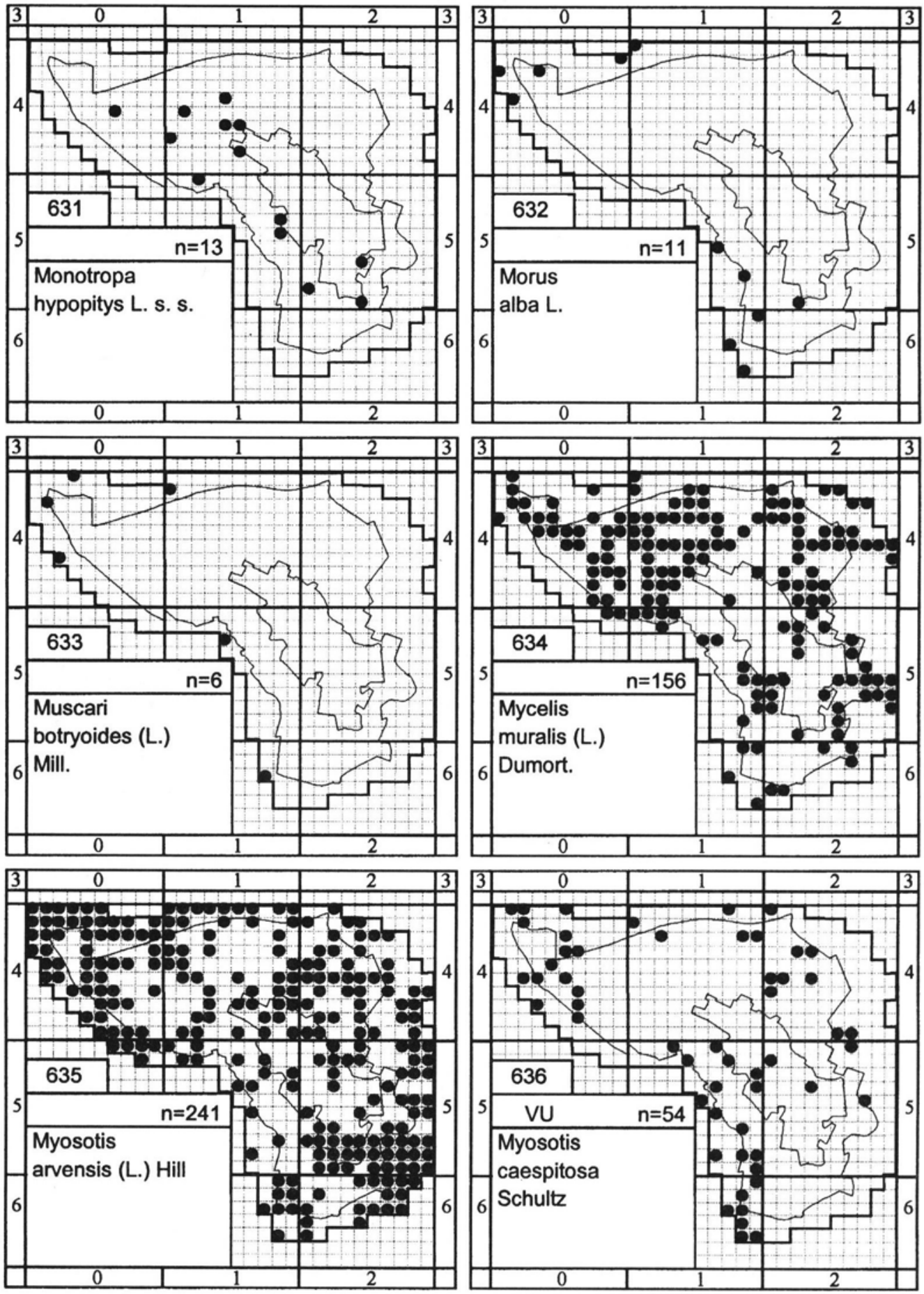



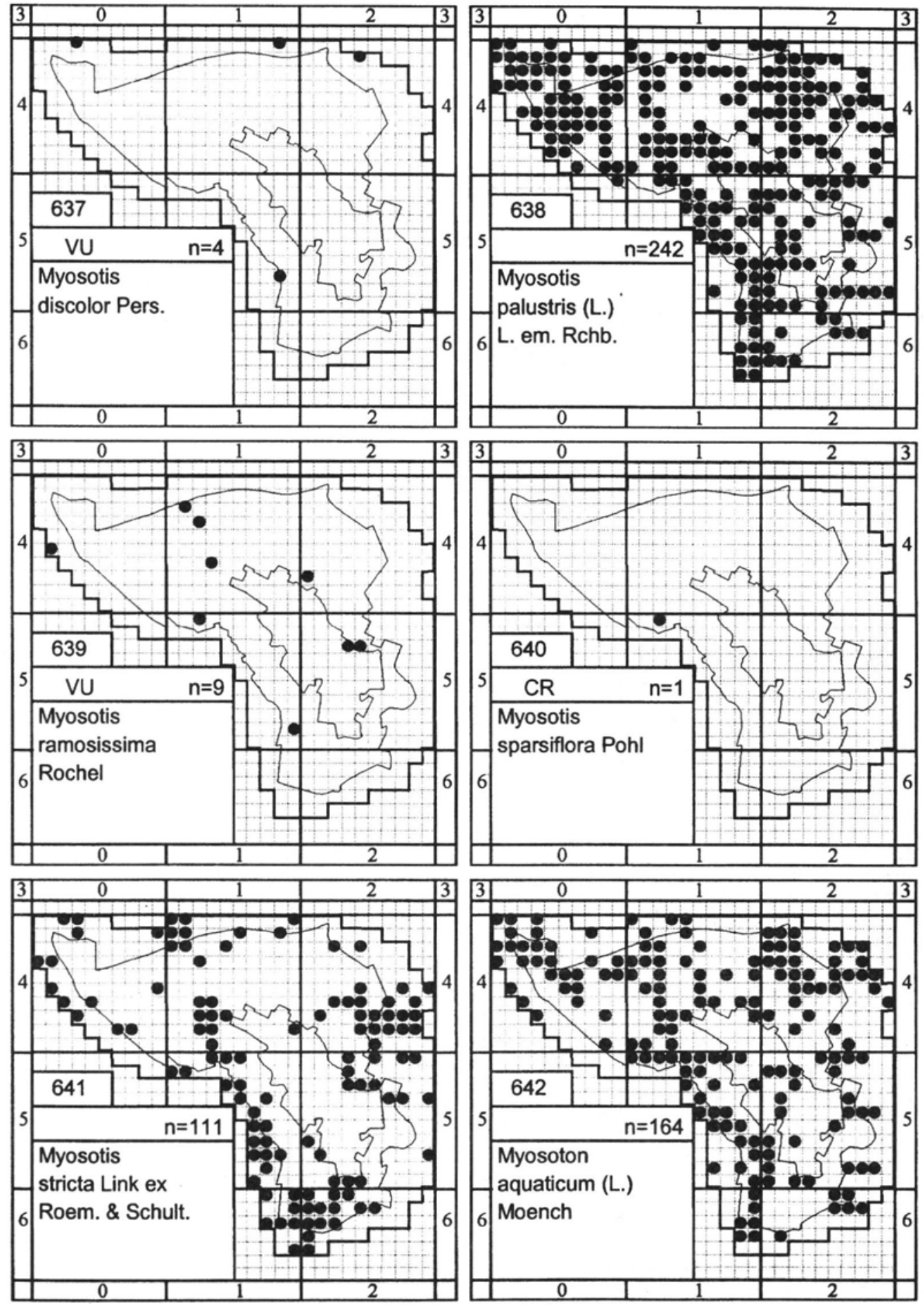


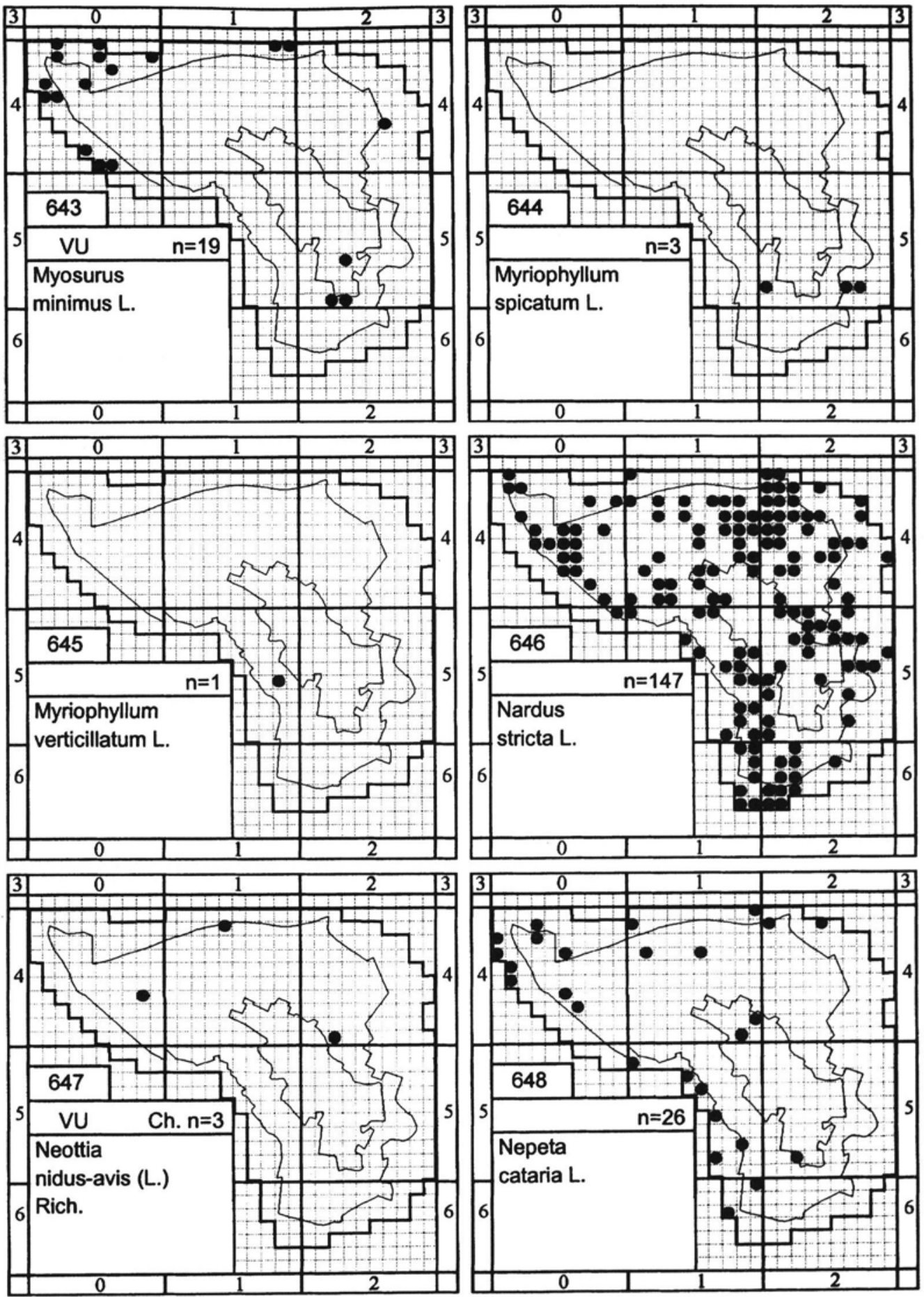



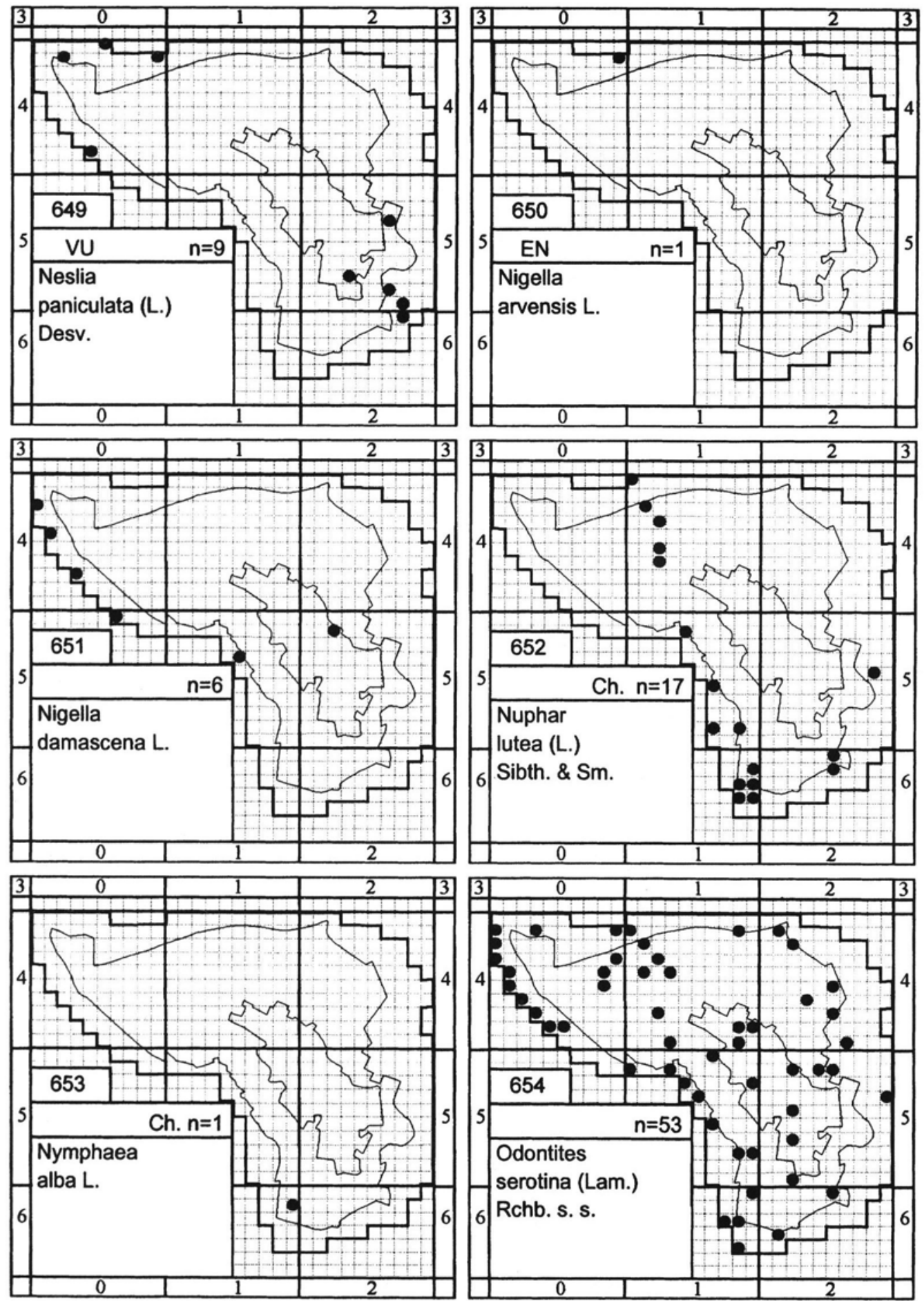


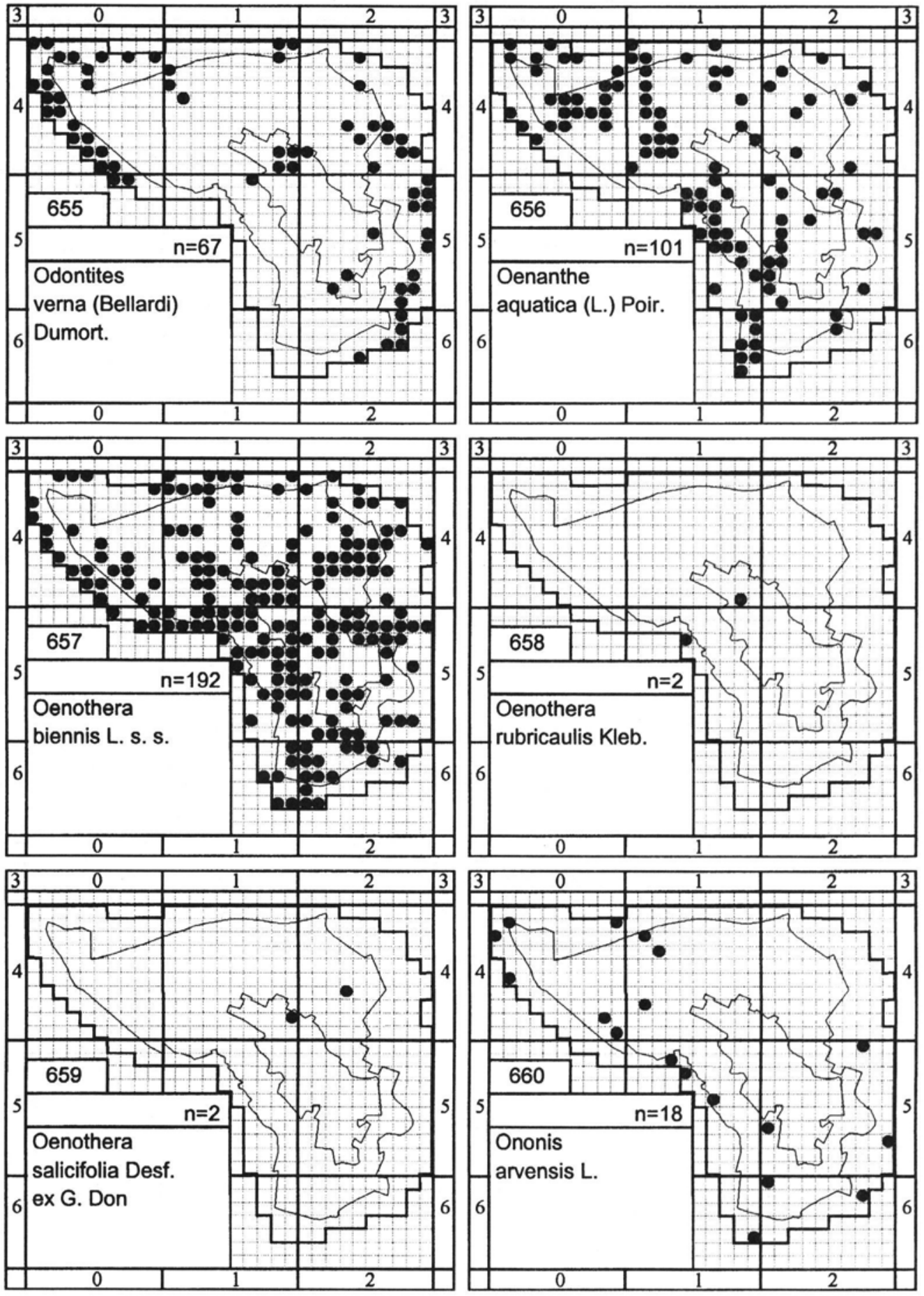




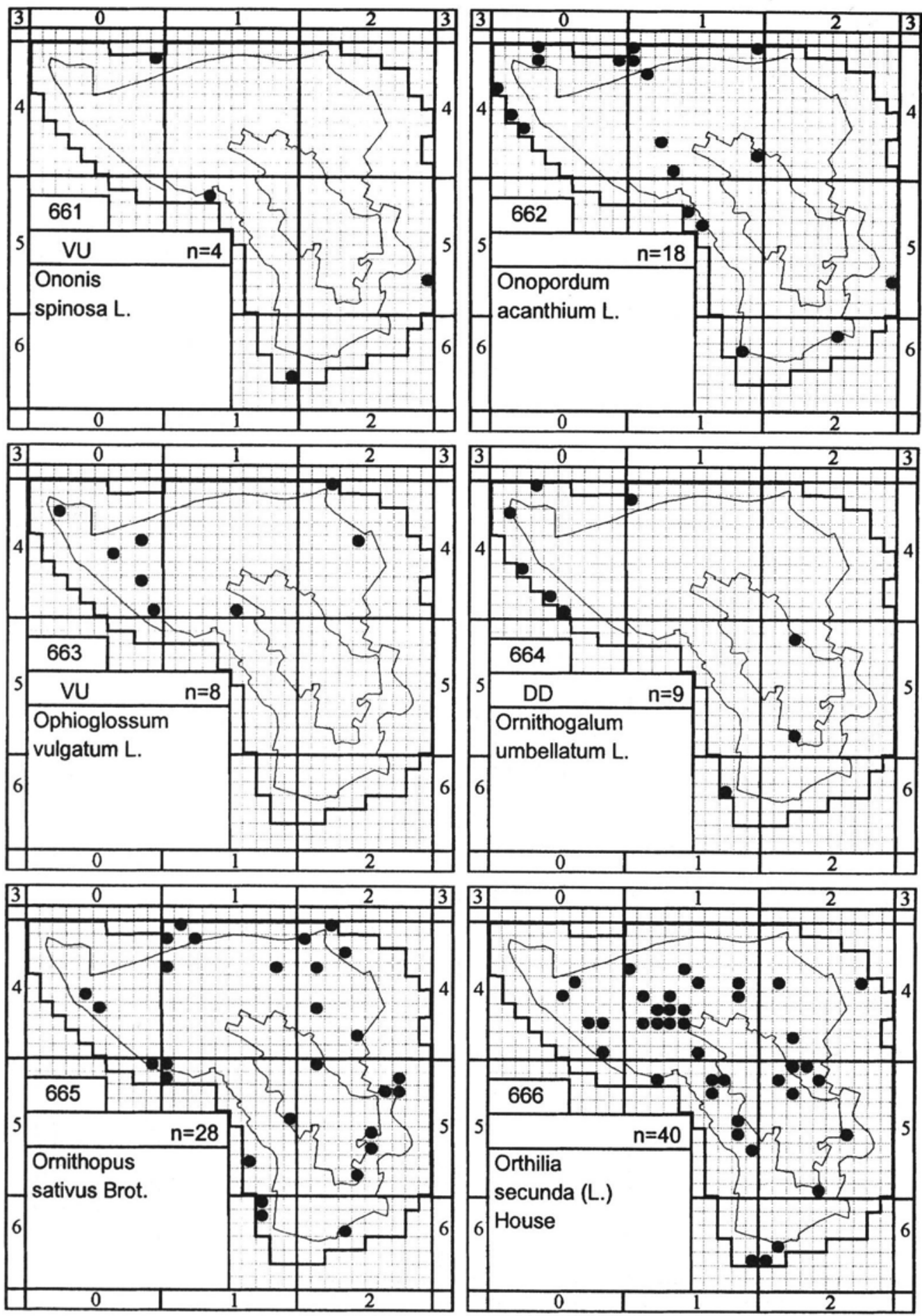




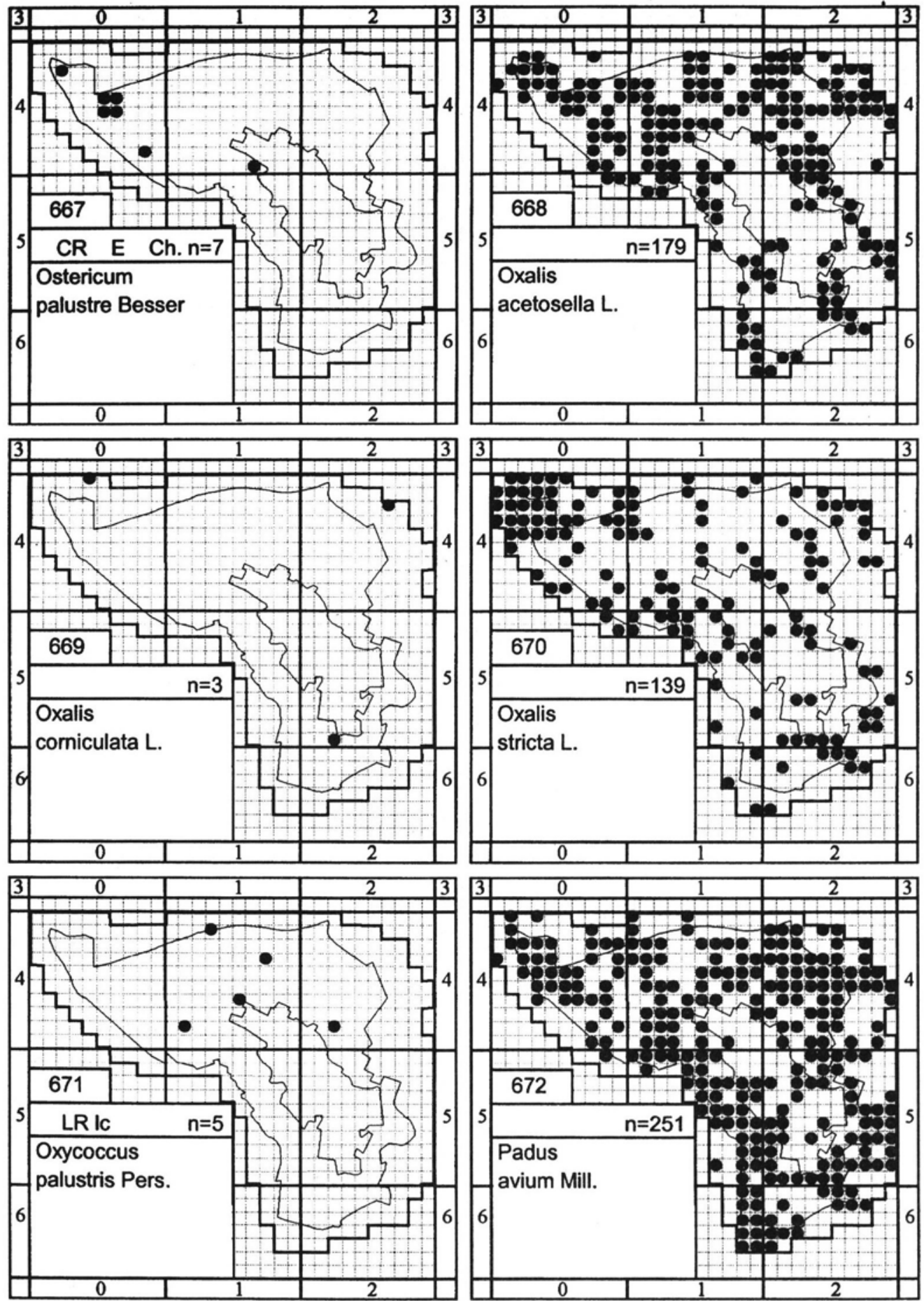



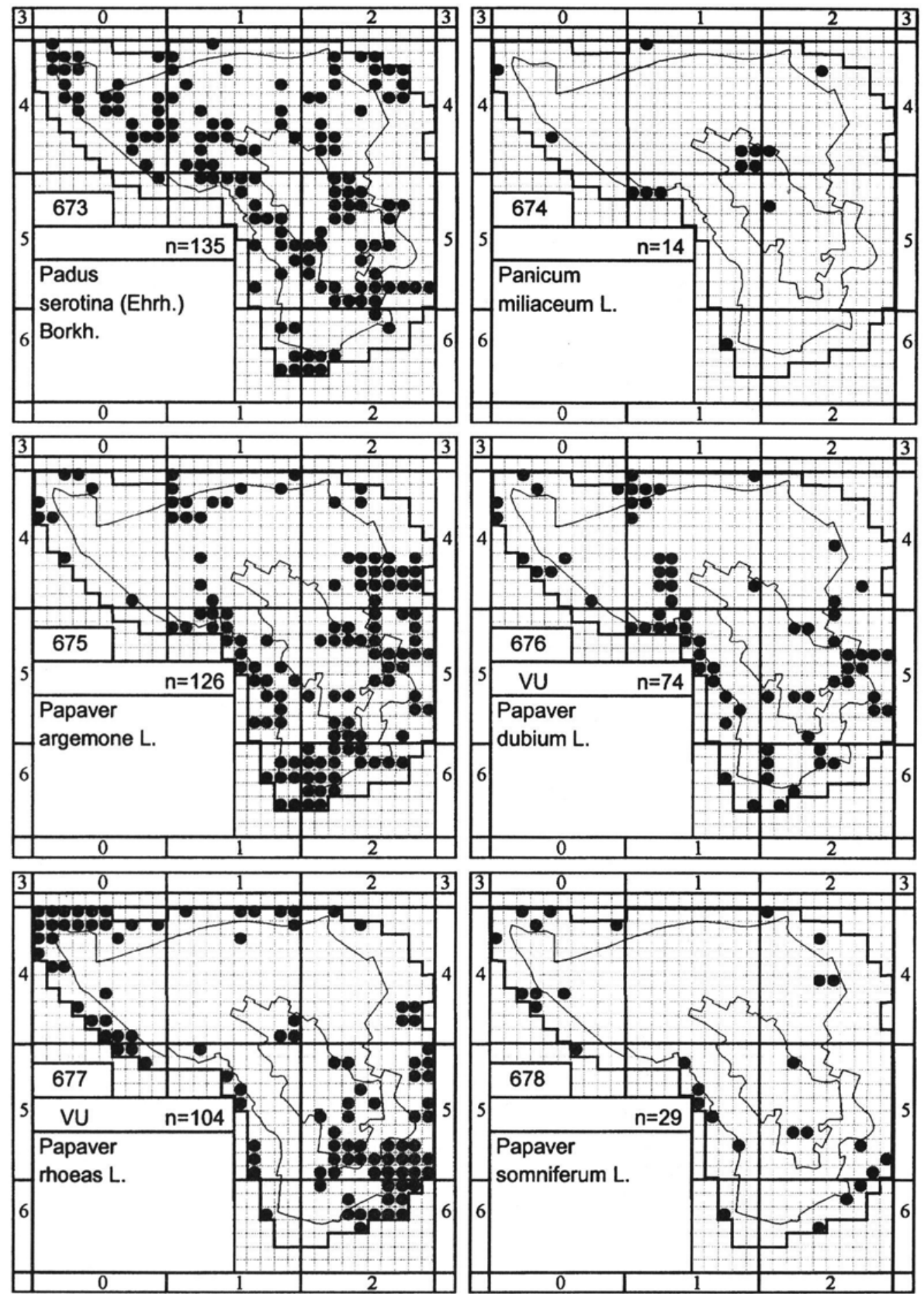


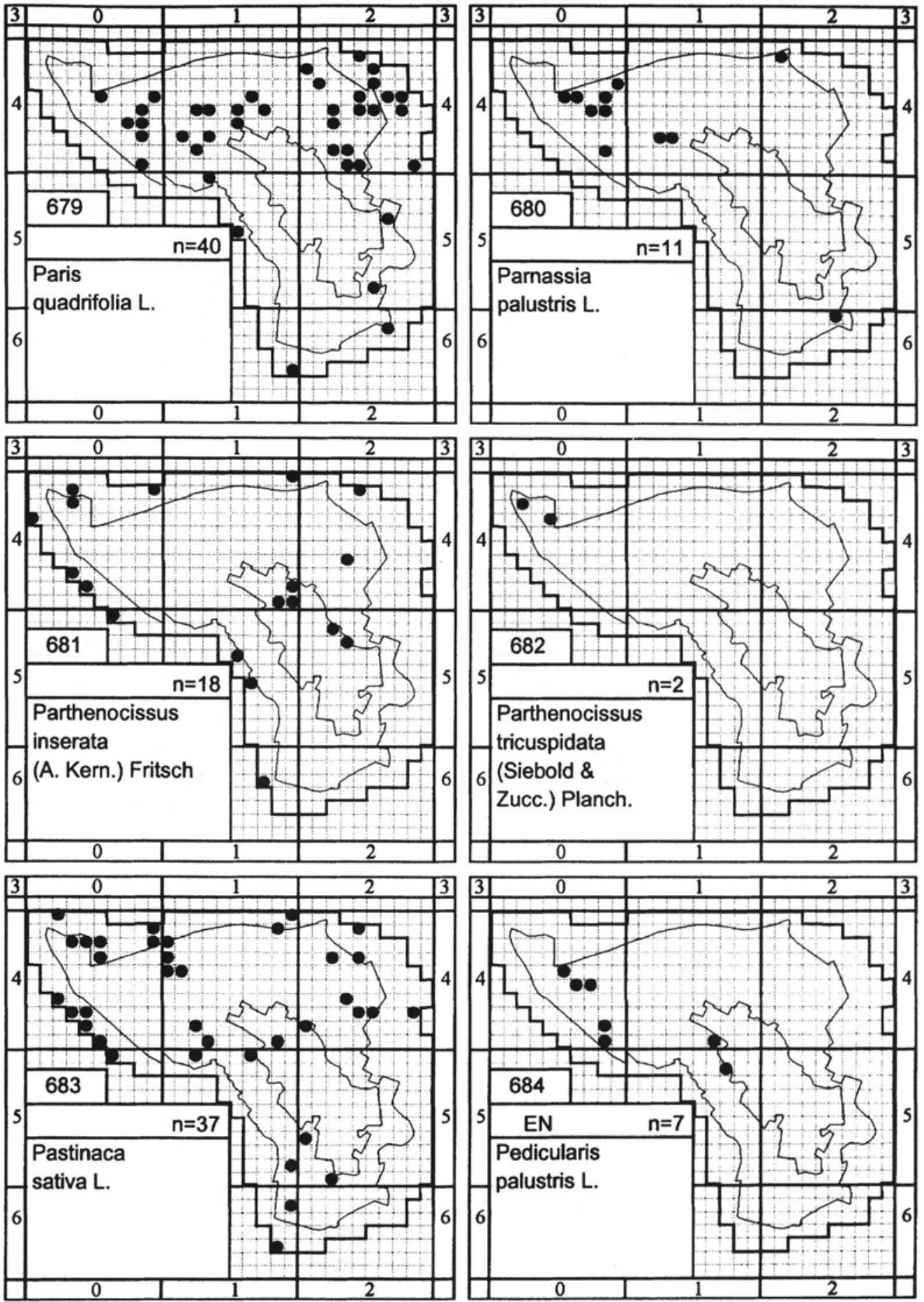



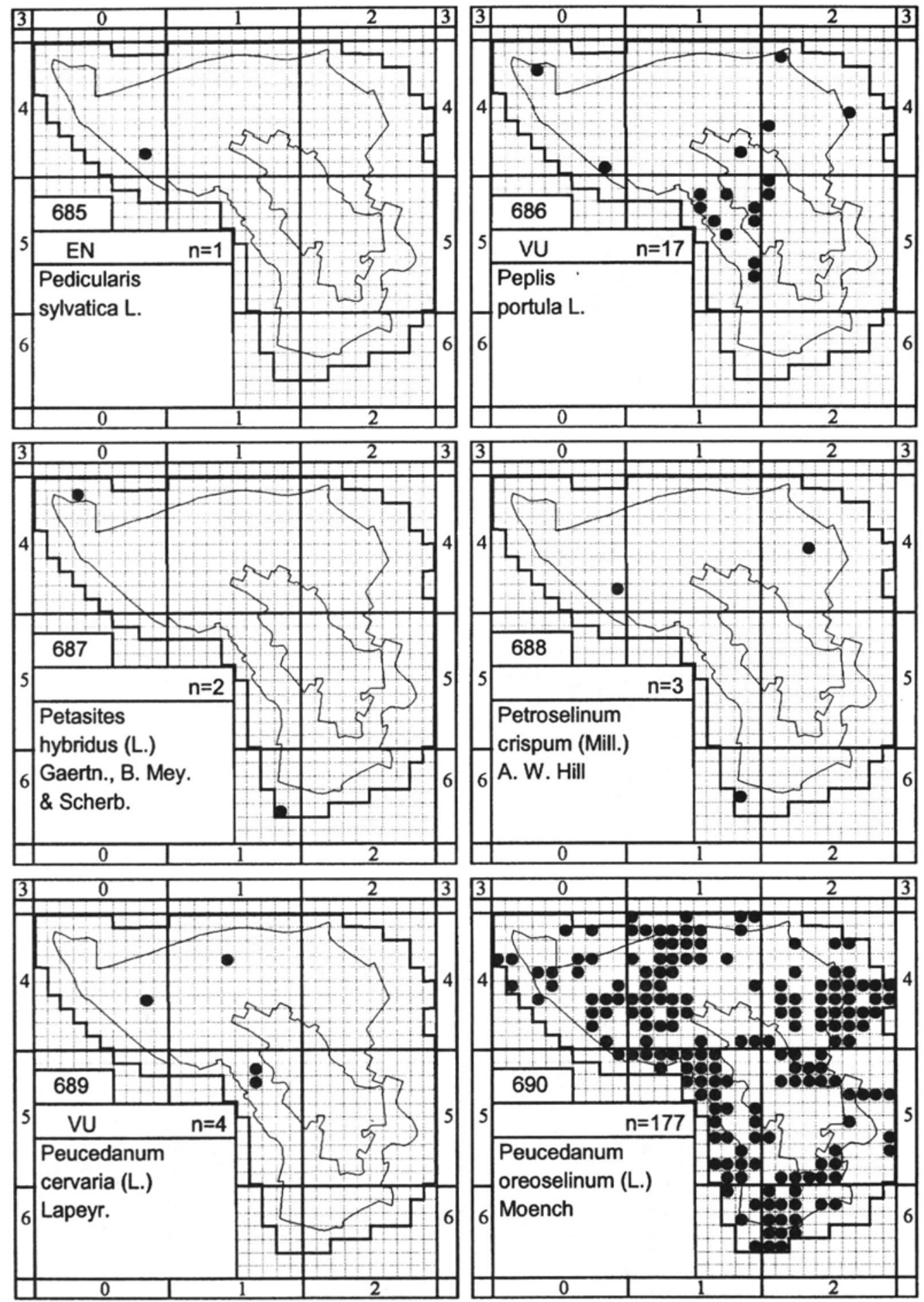

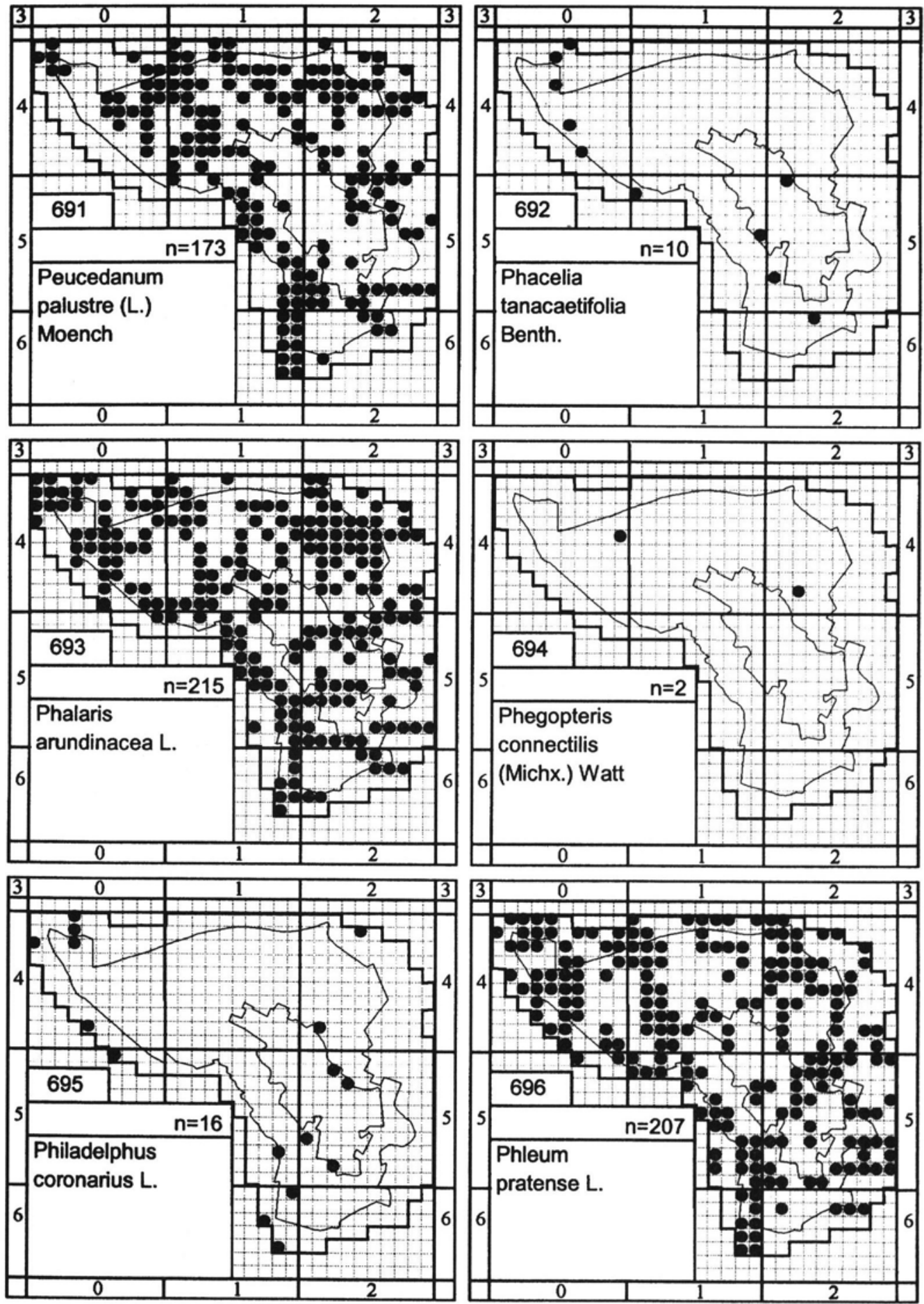


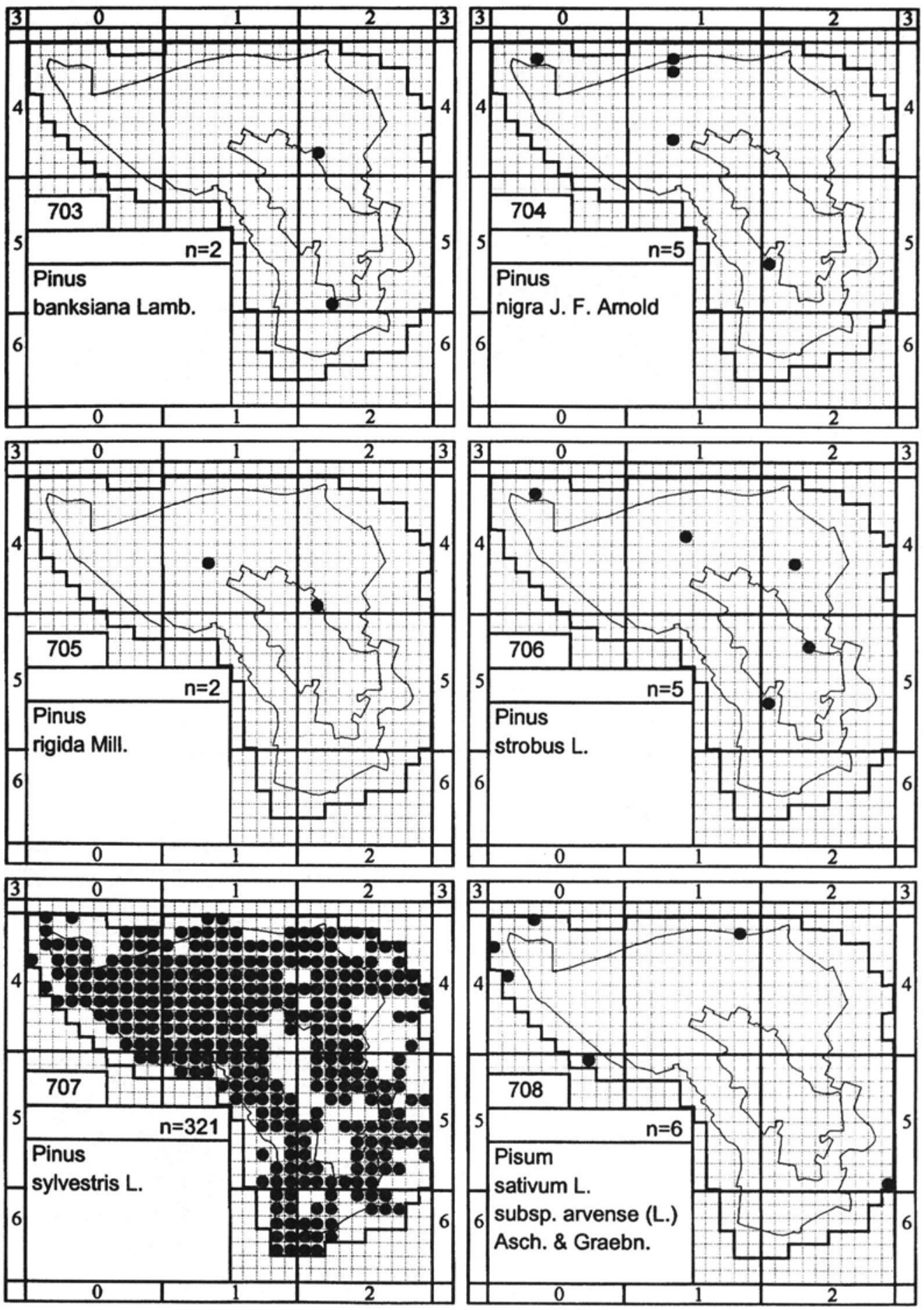




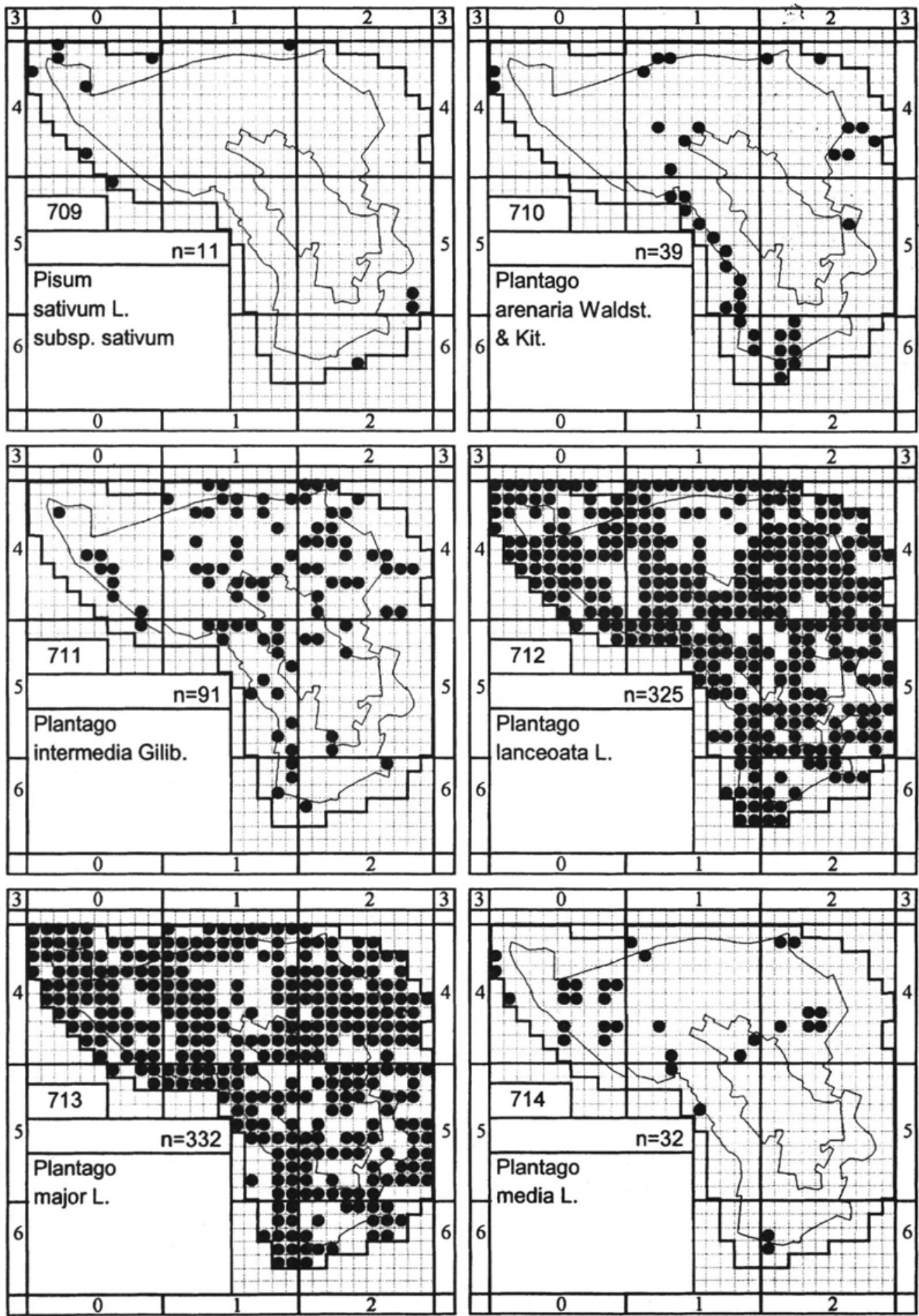



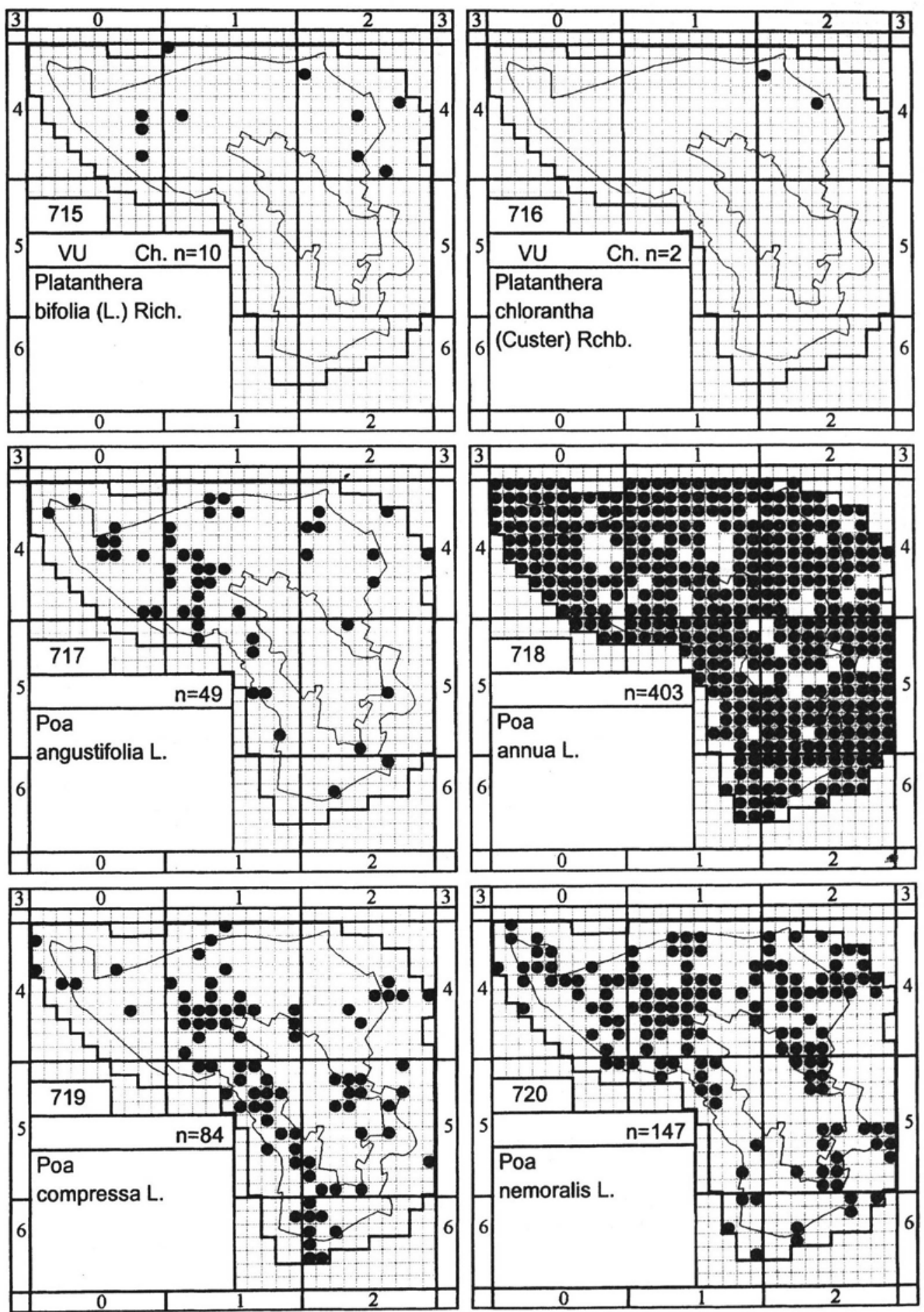

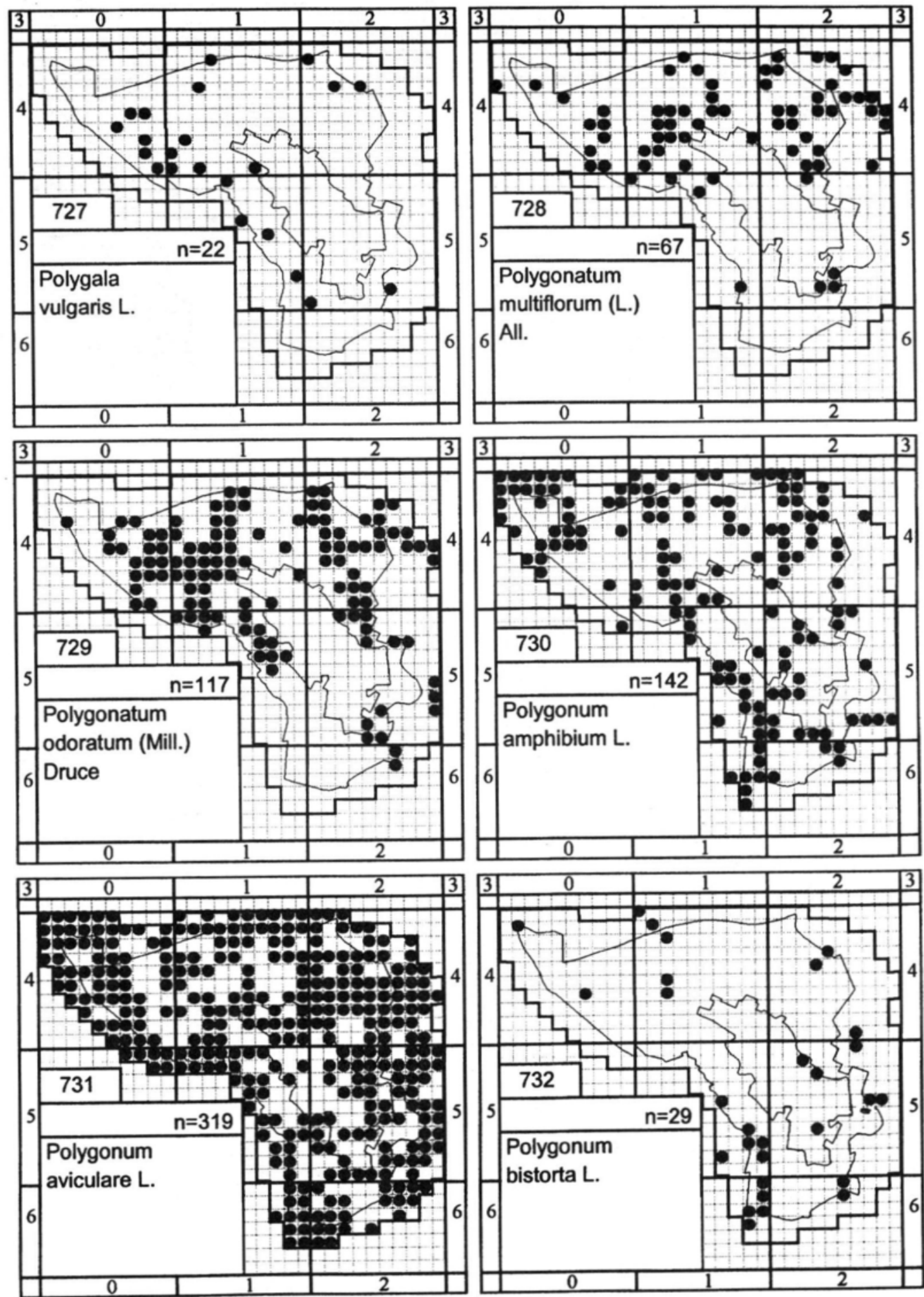

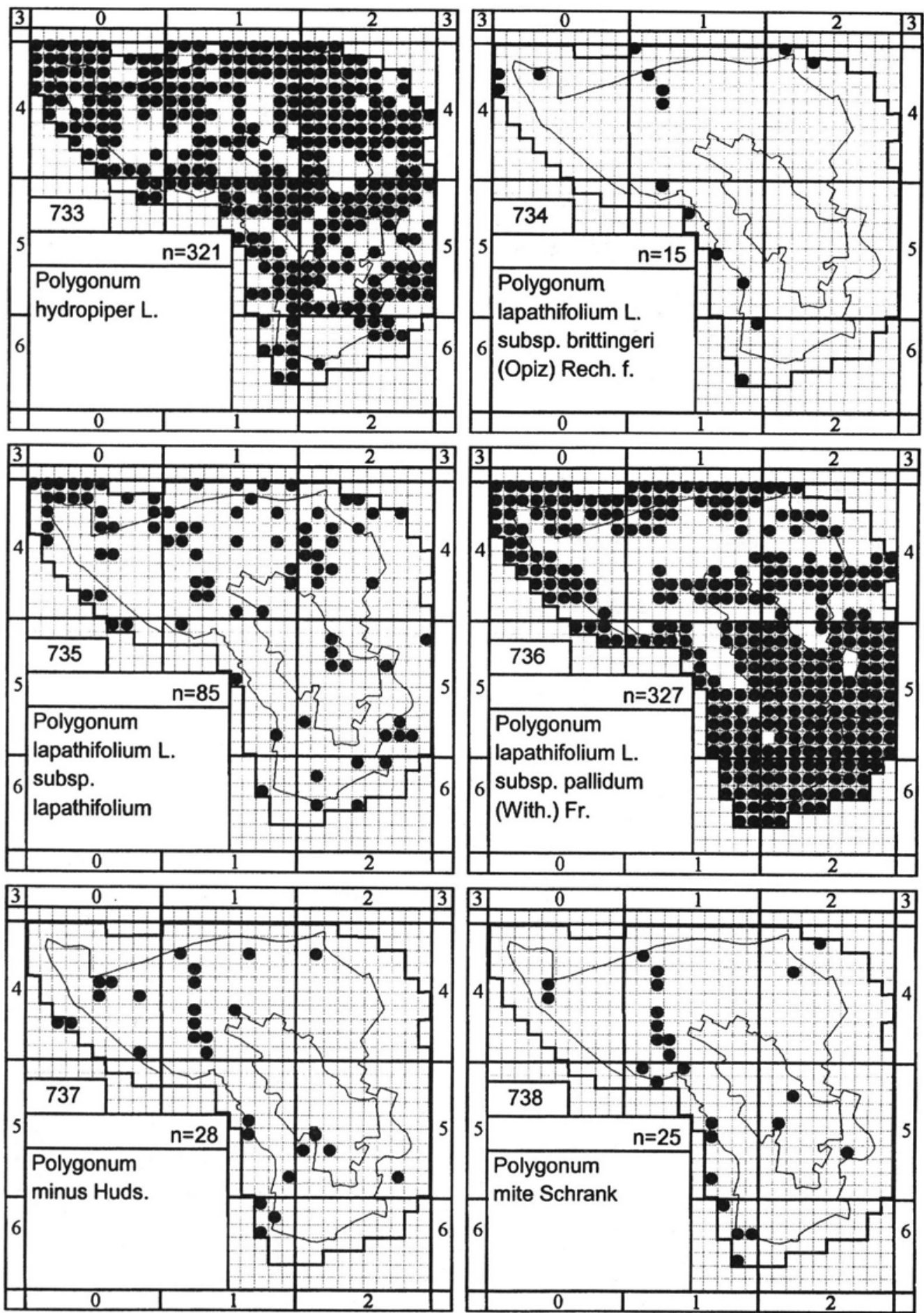

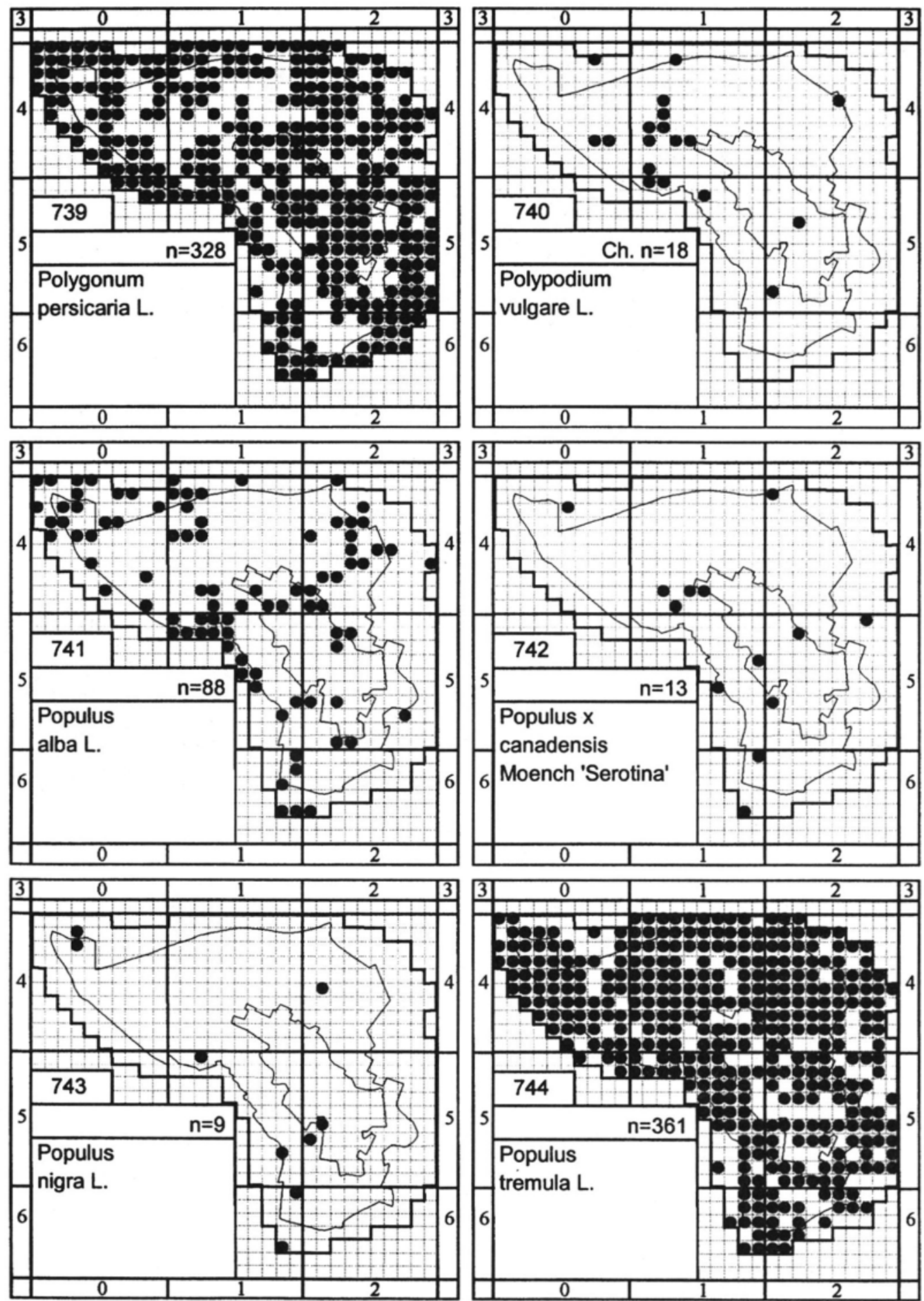

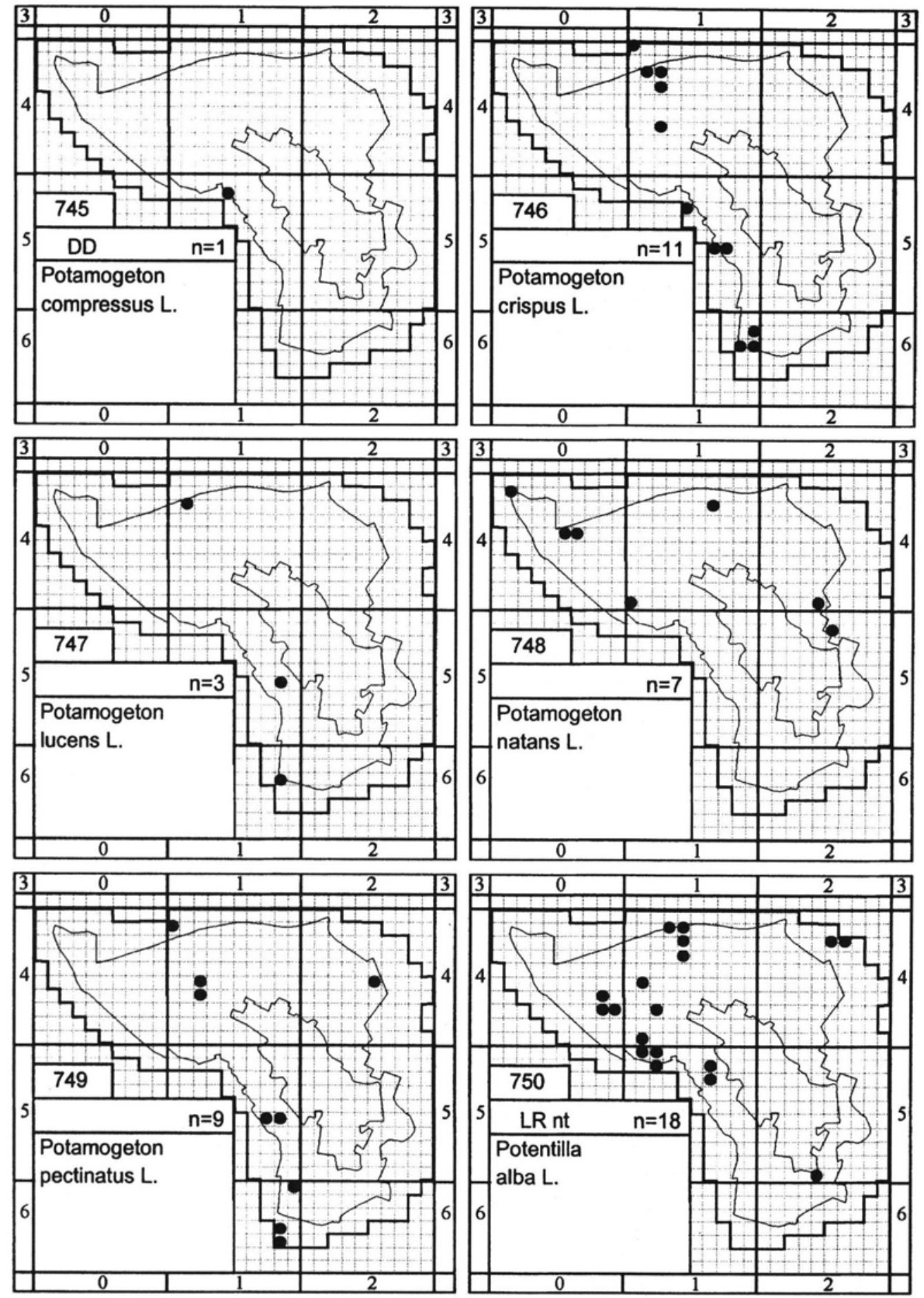

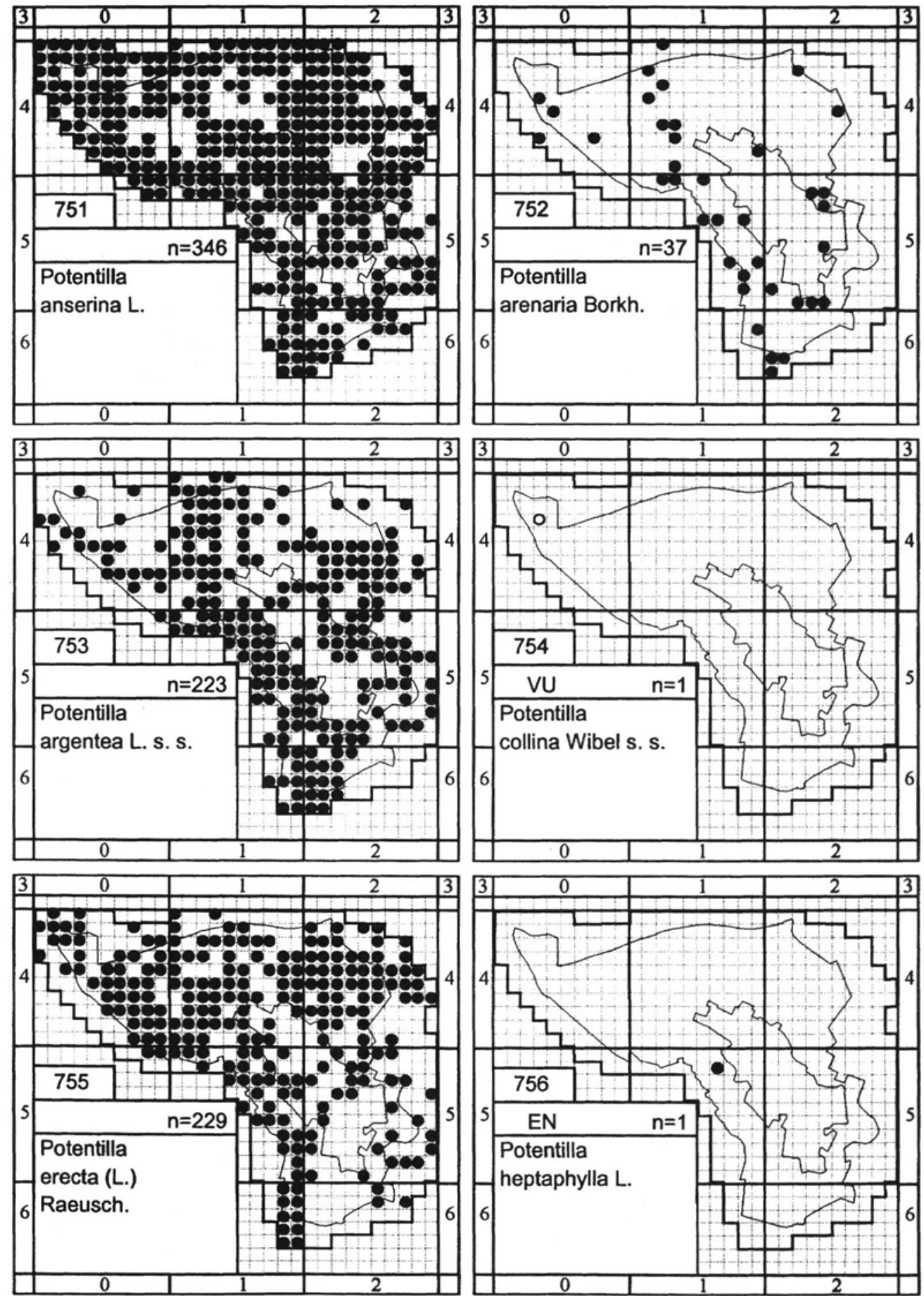


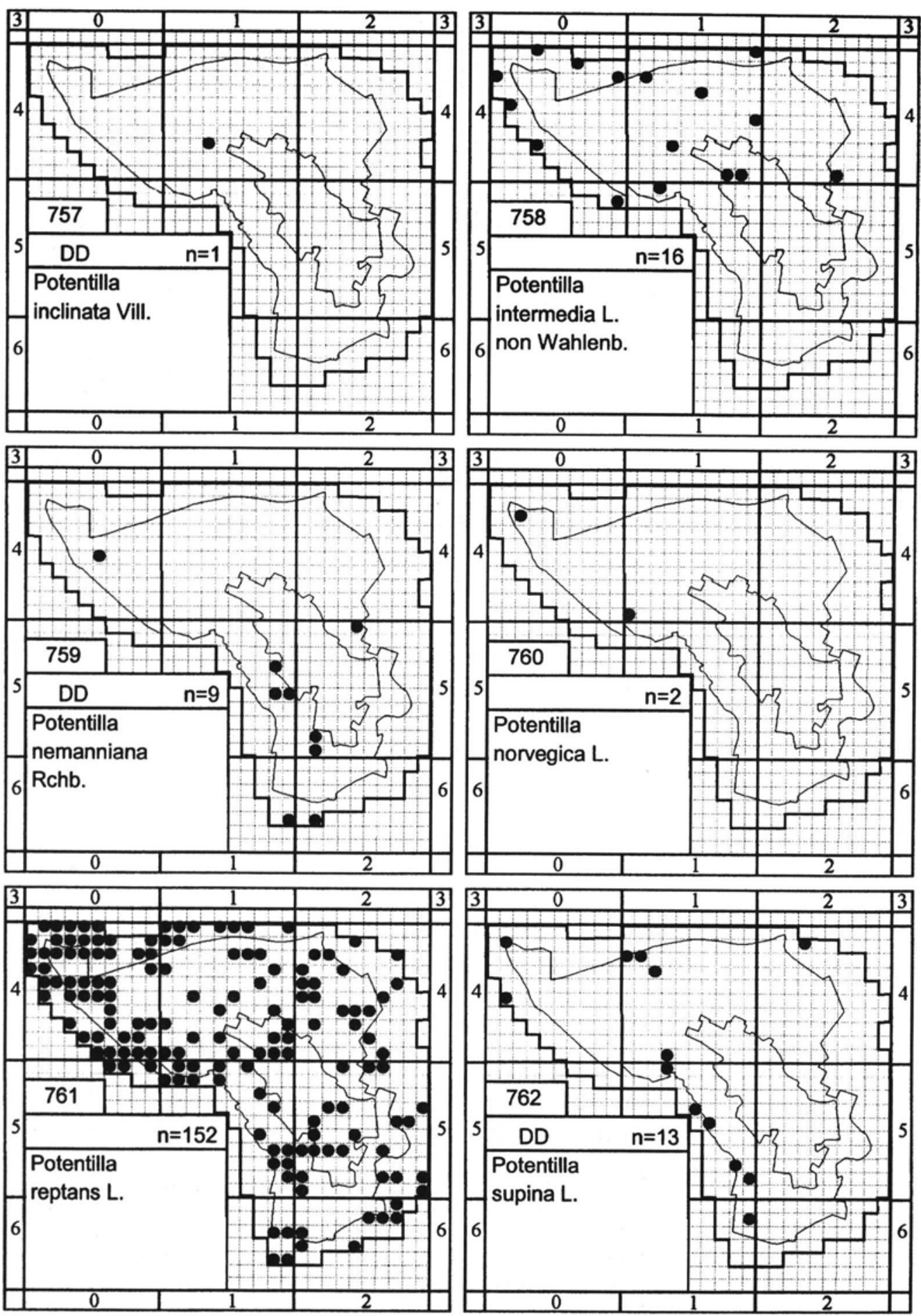



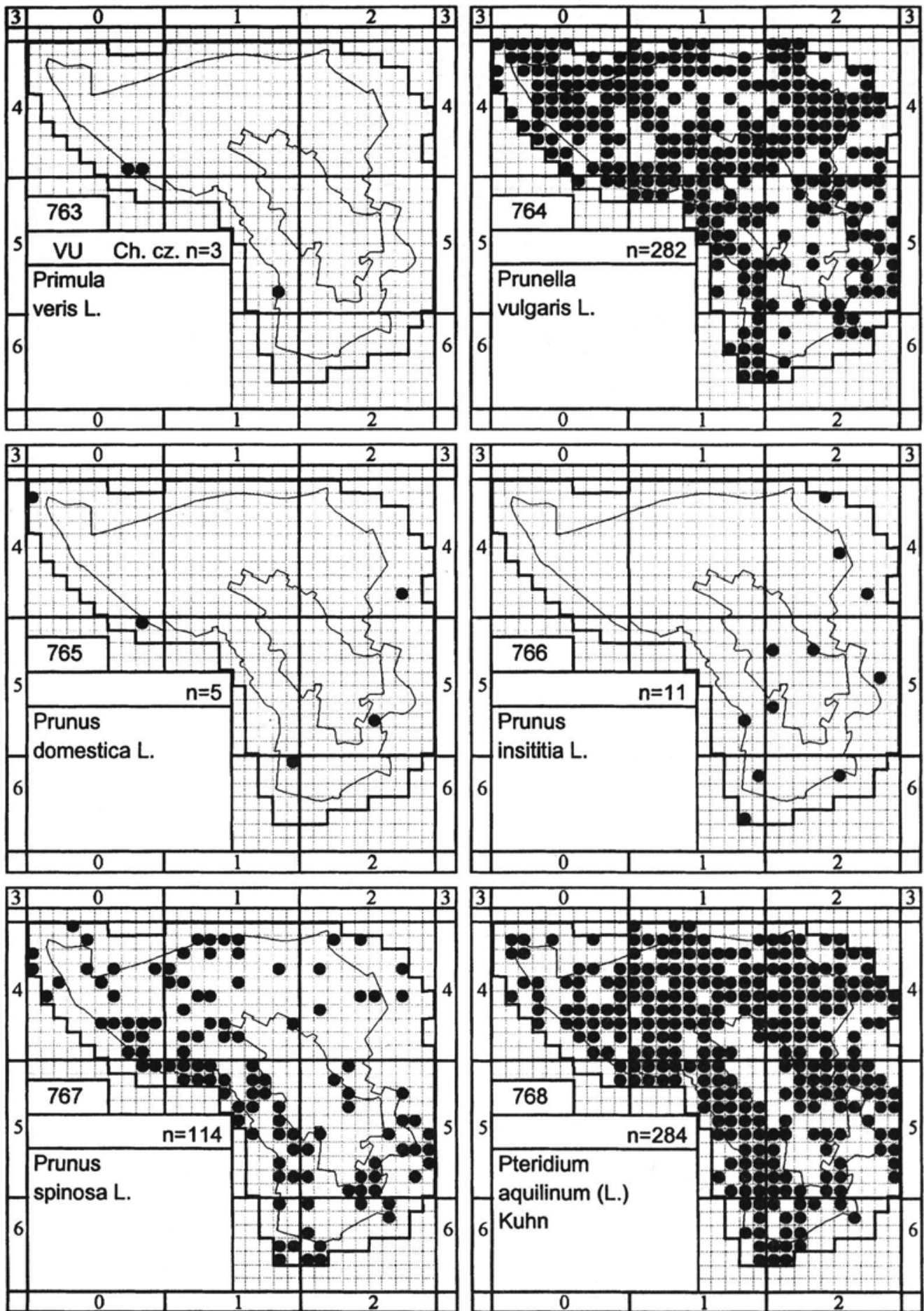

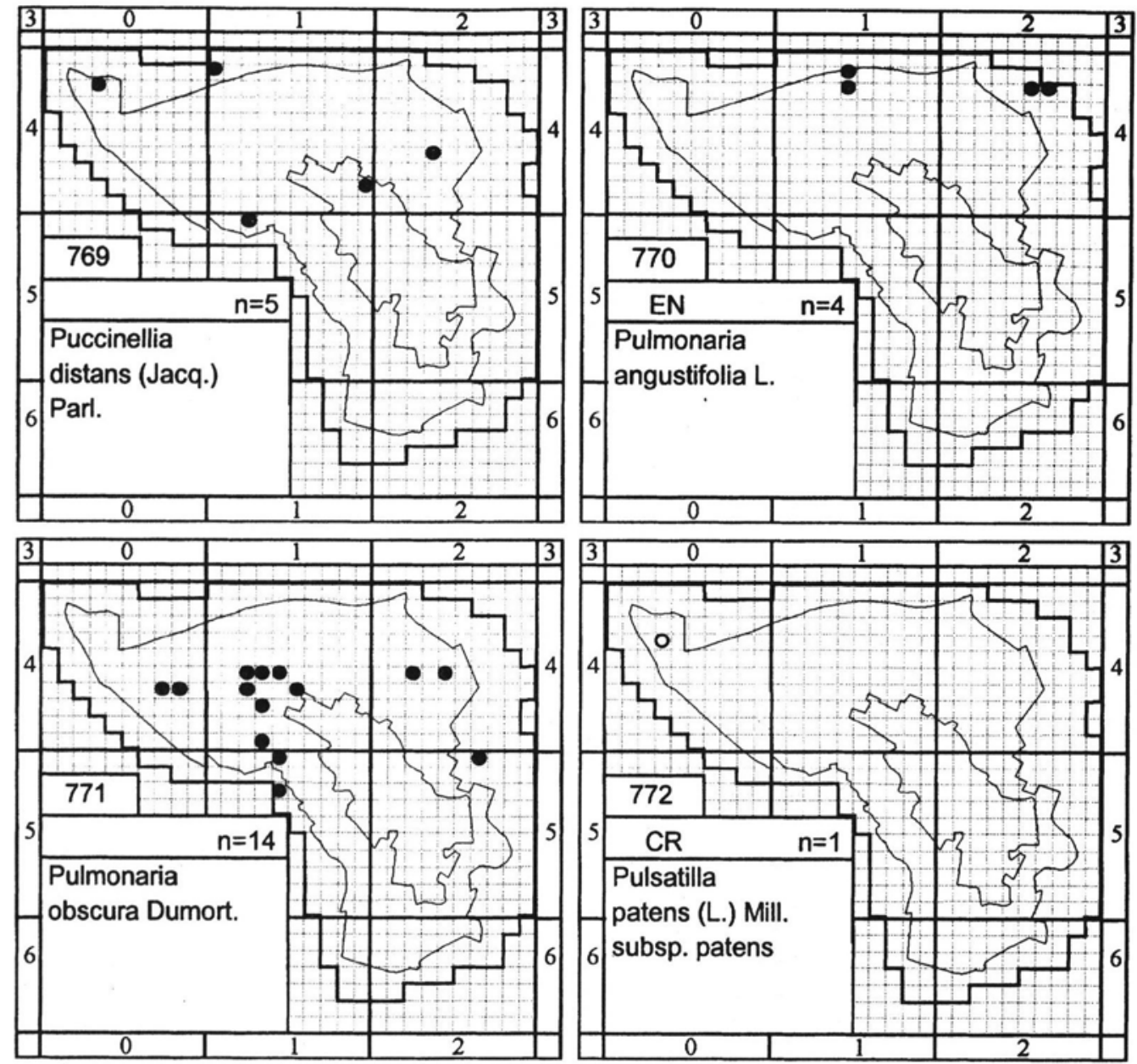

.

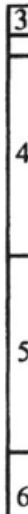

3

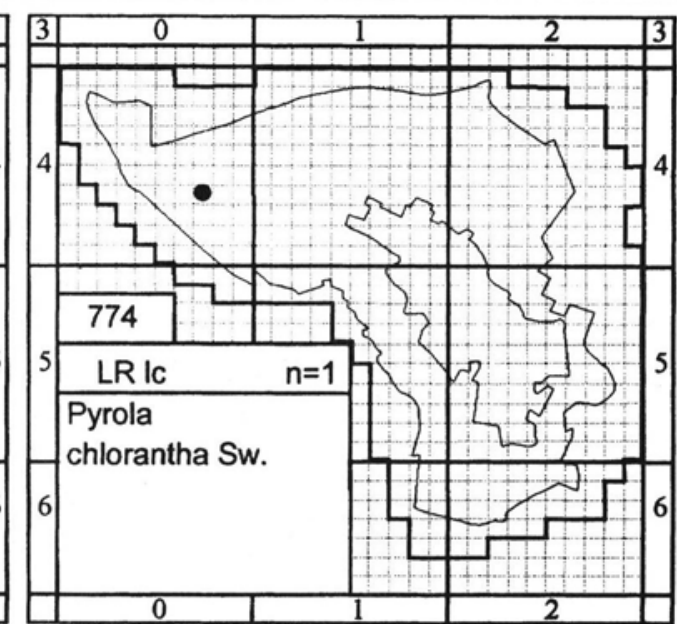



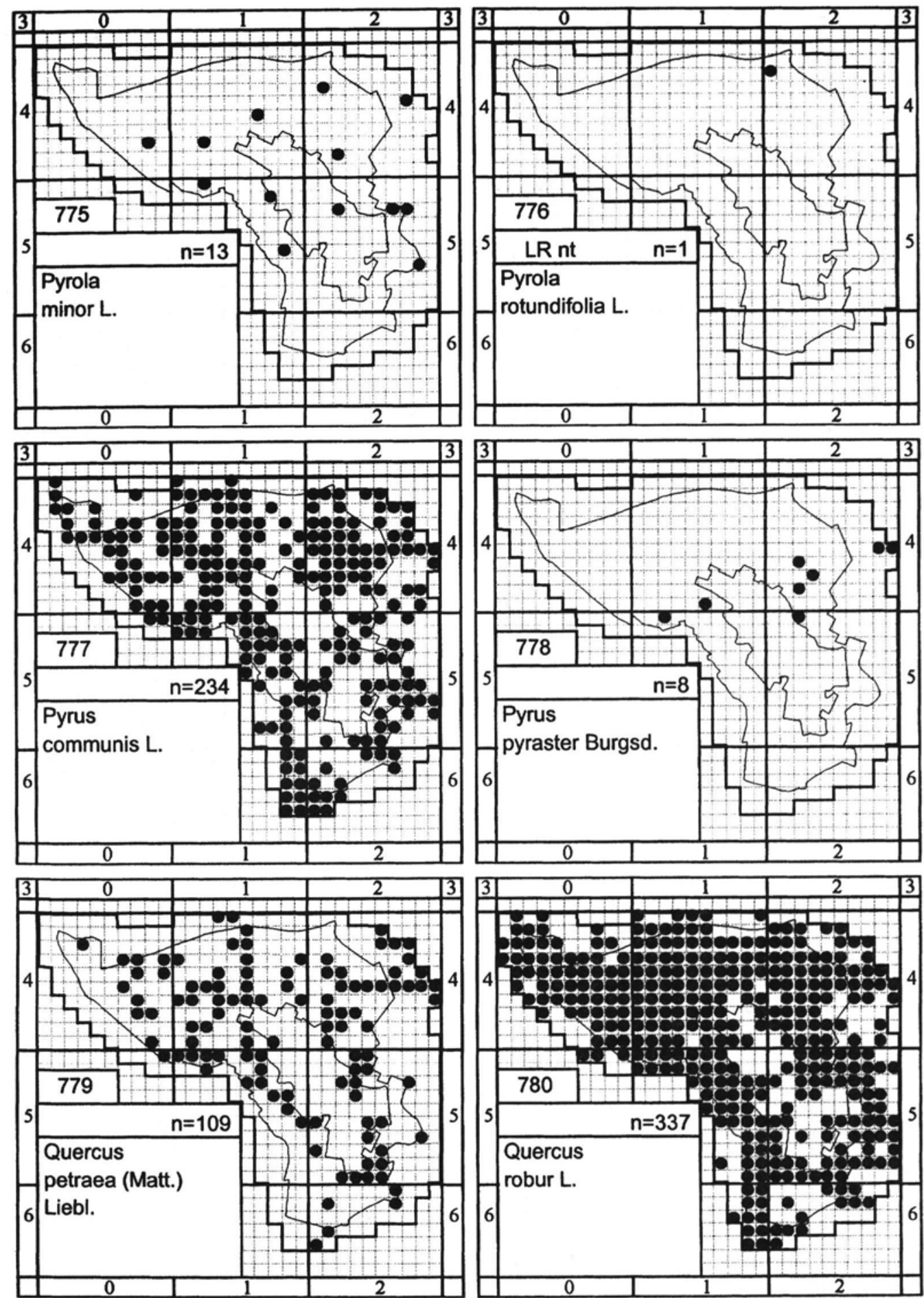

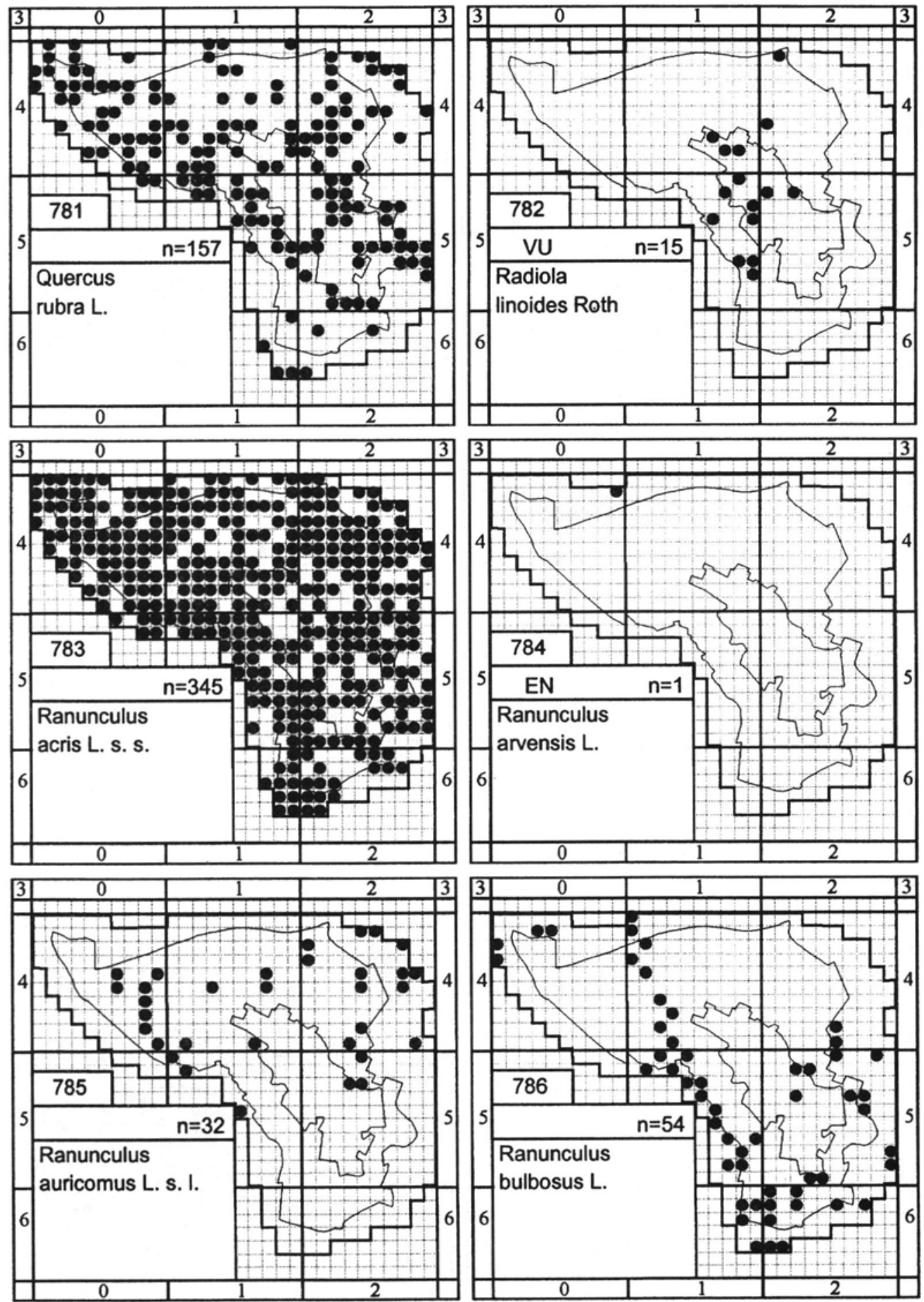

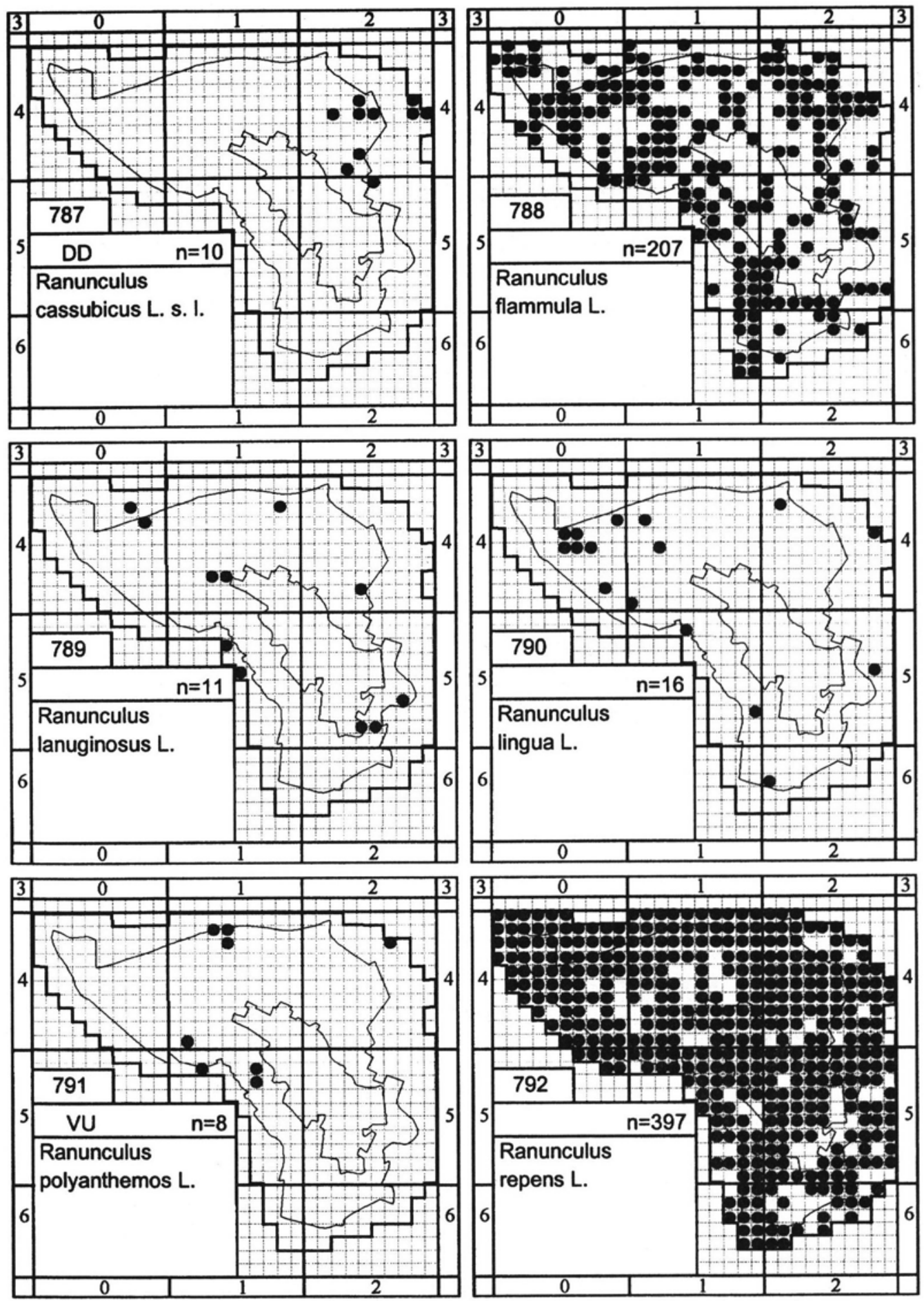


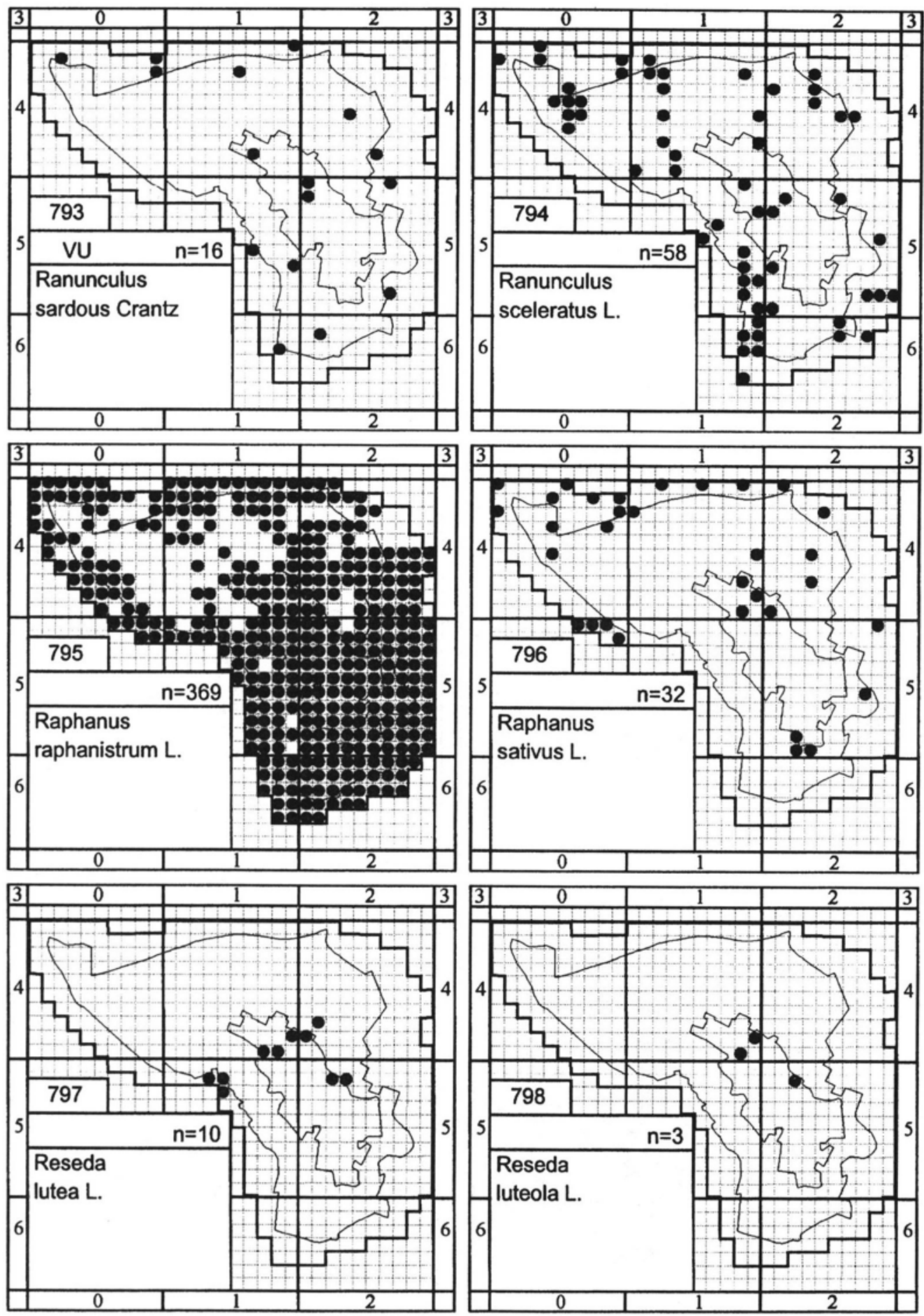



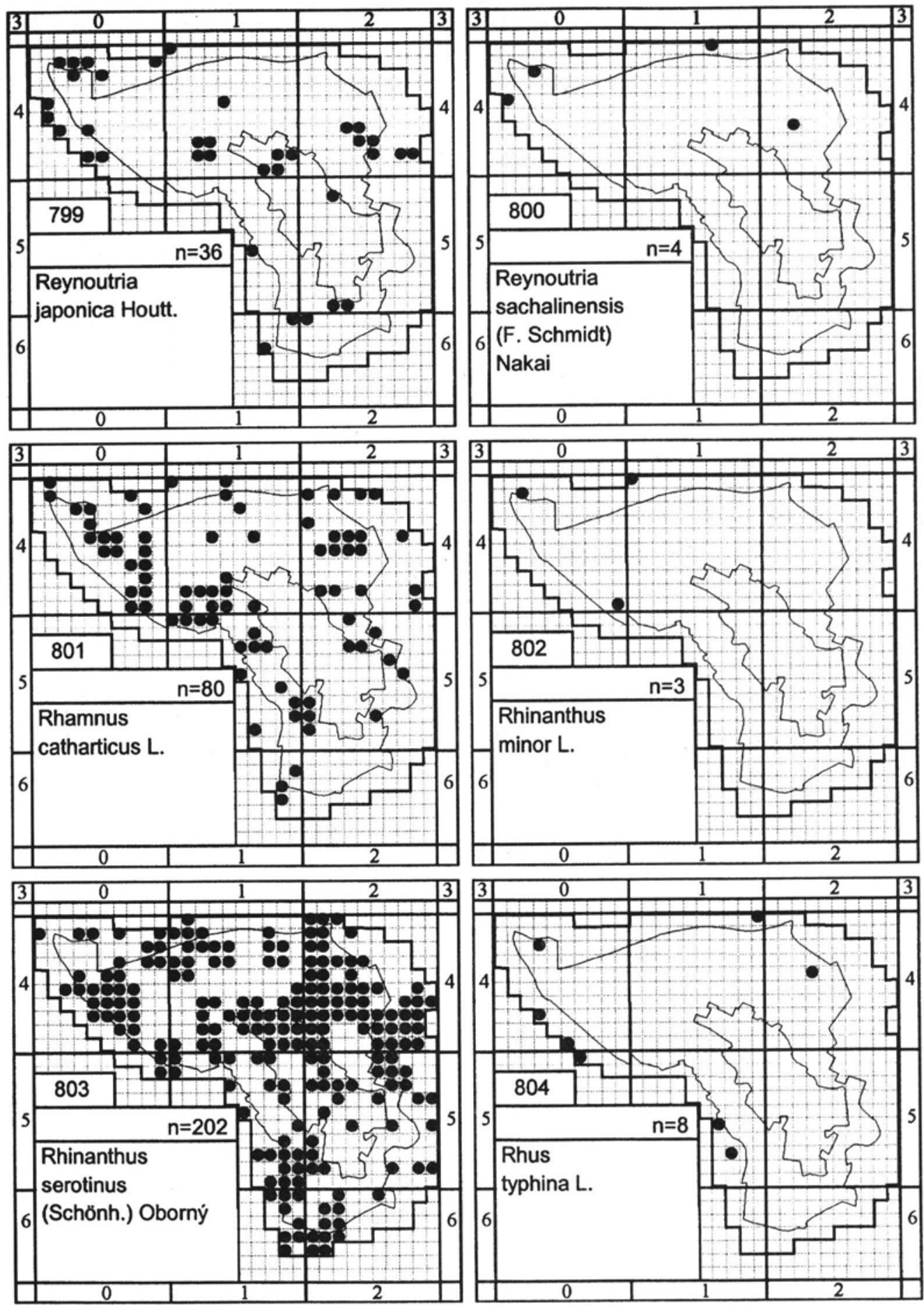


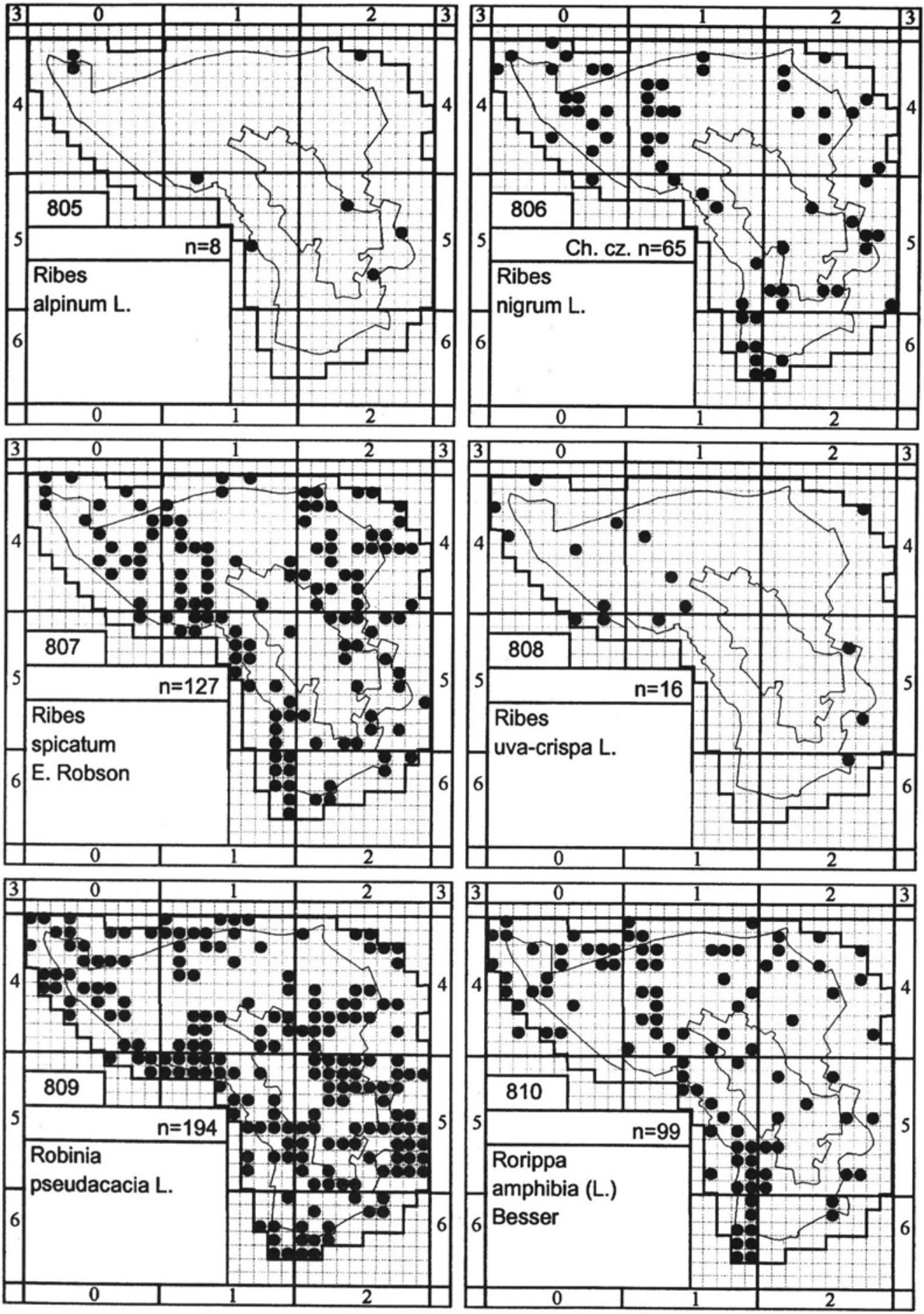



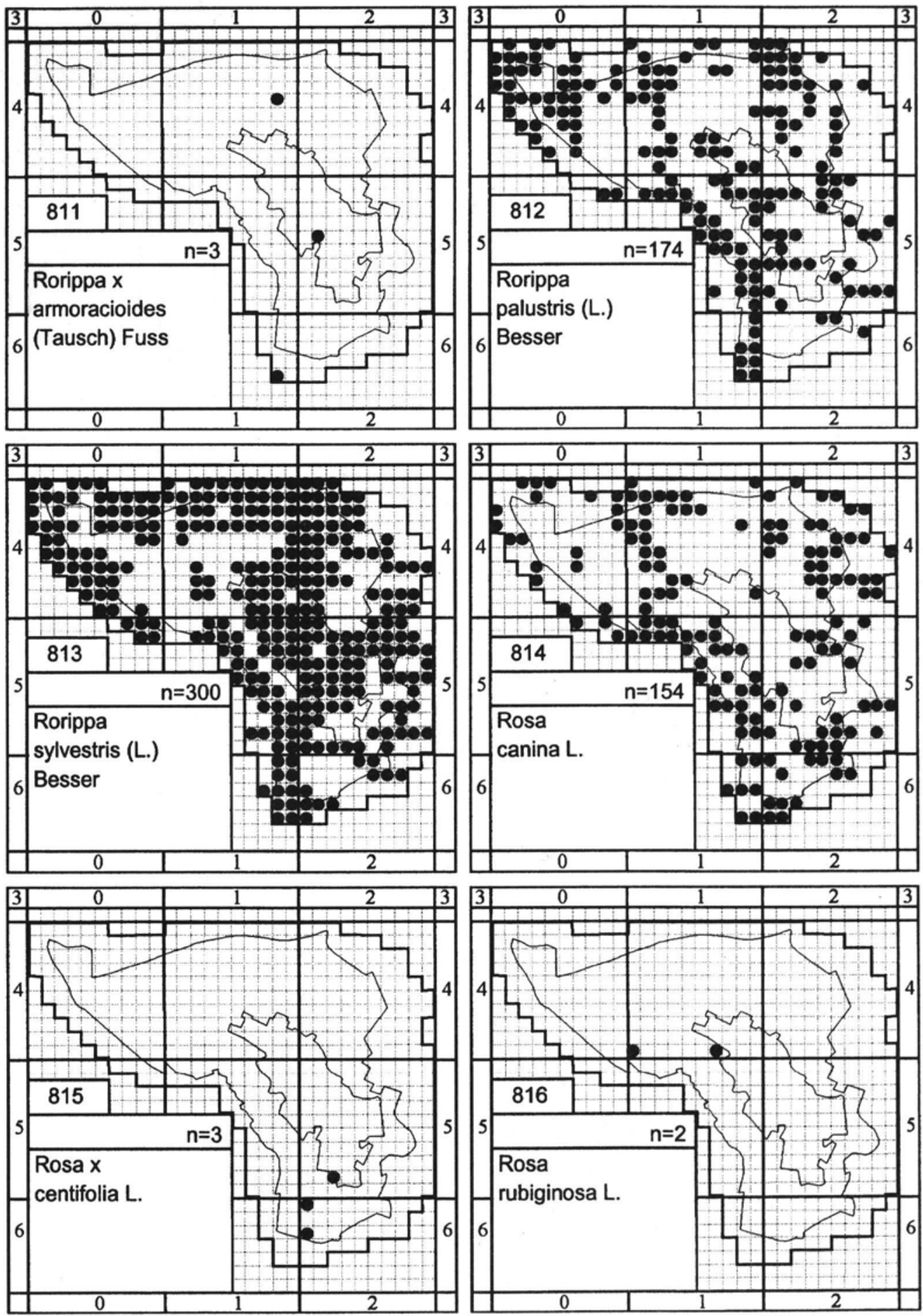

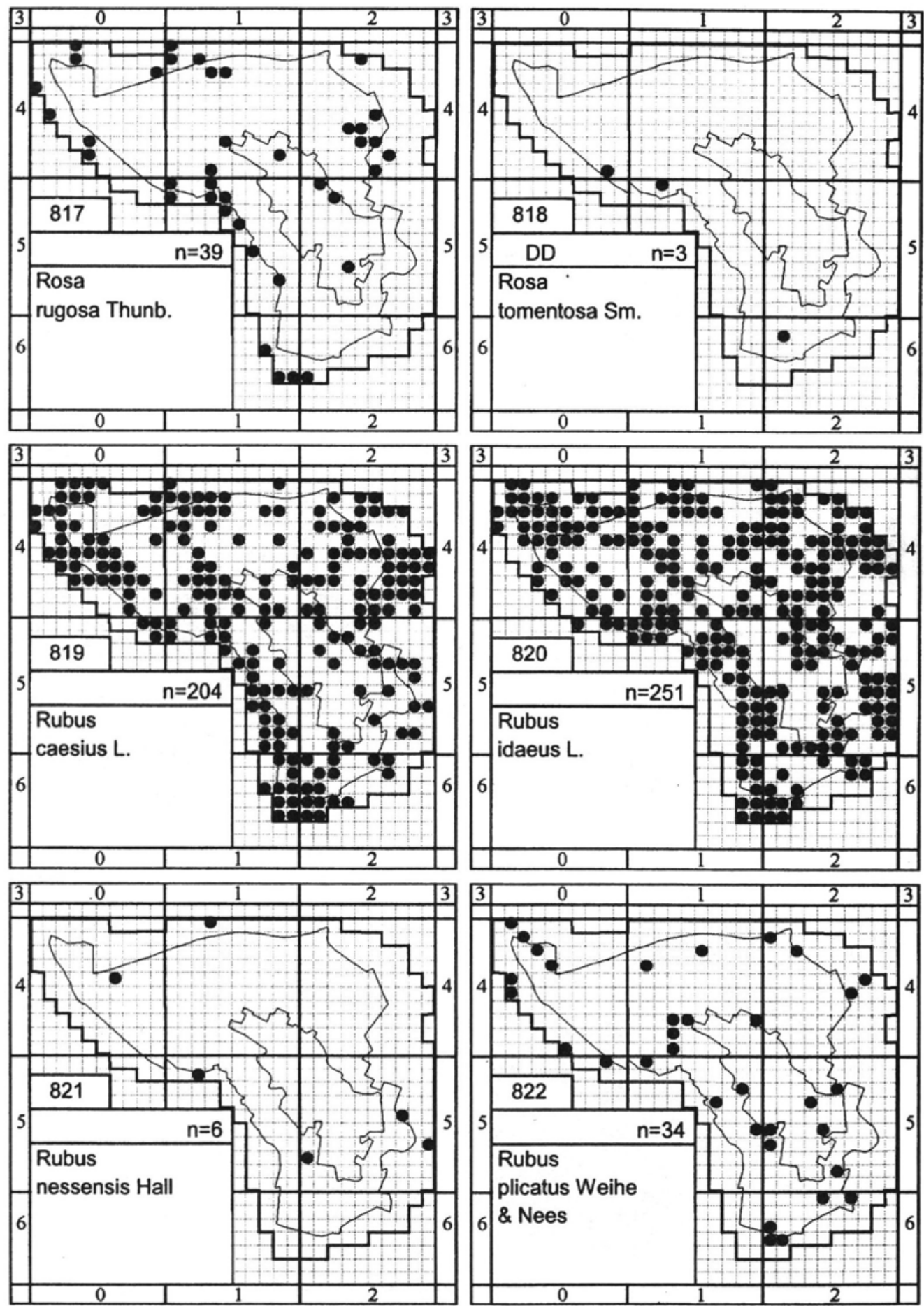

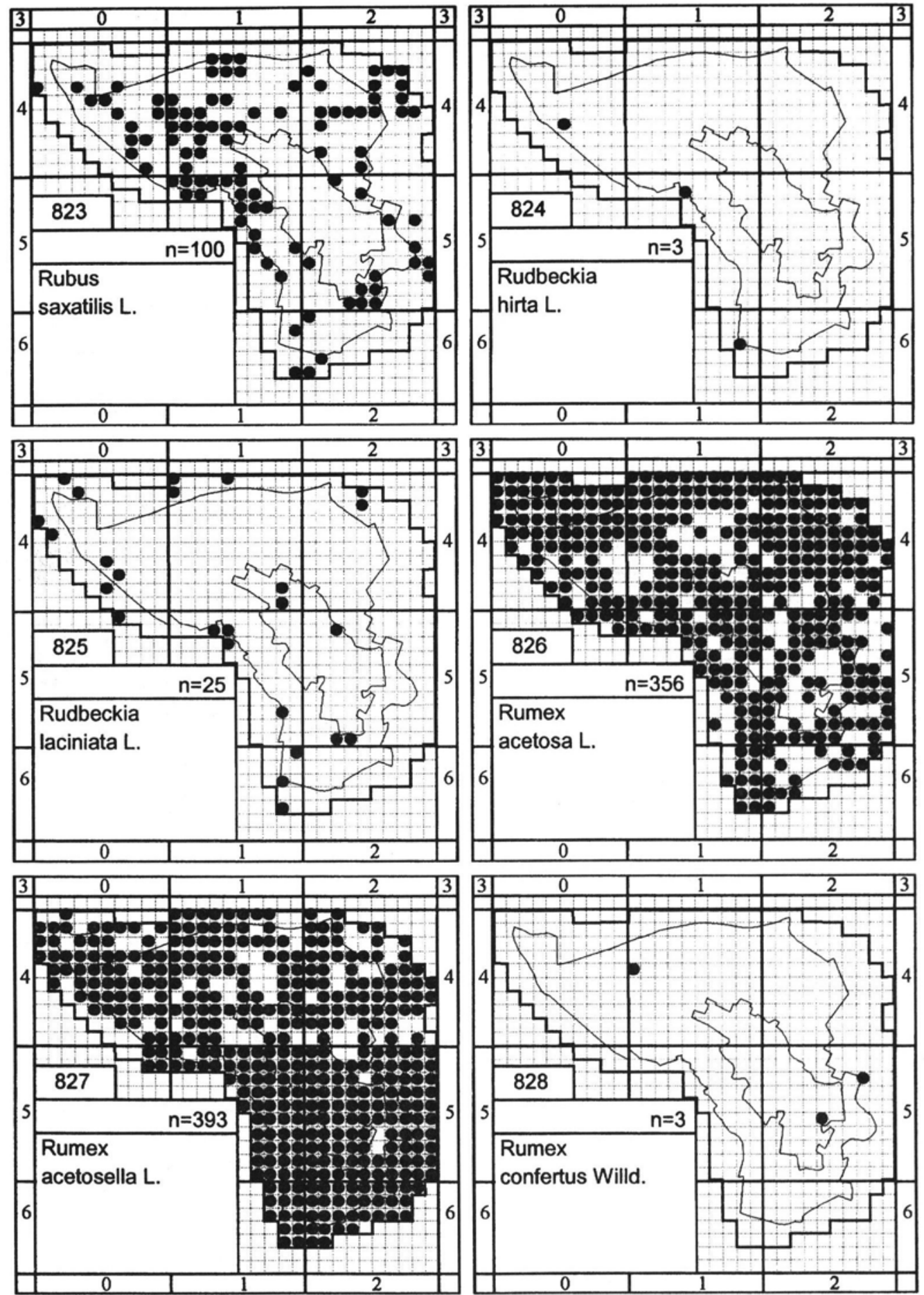

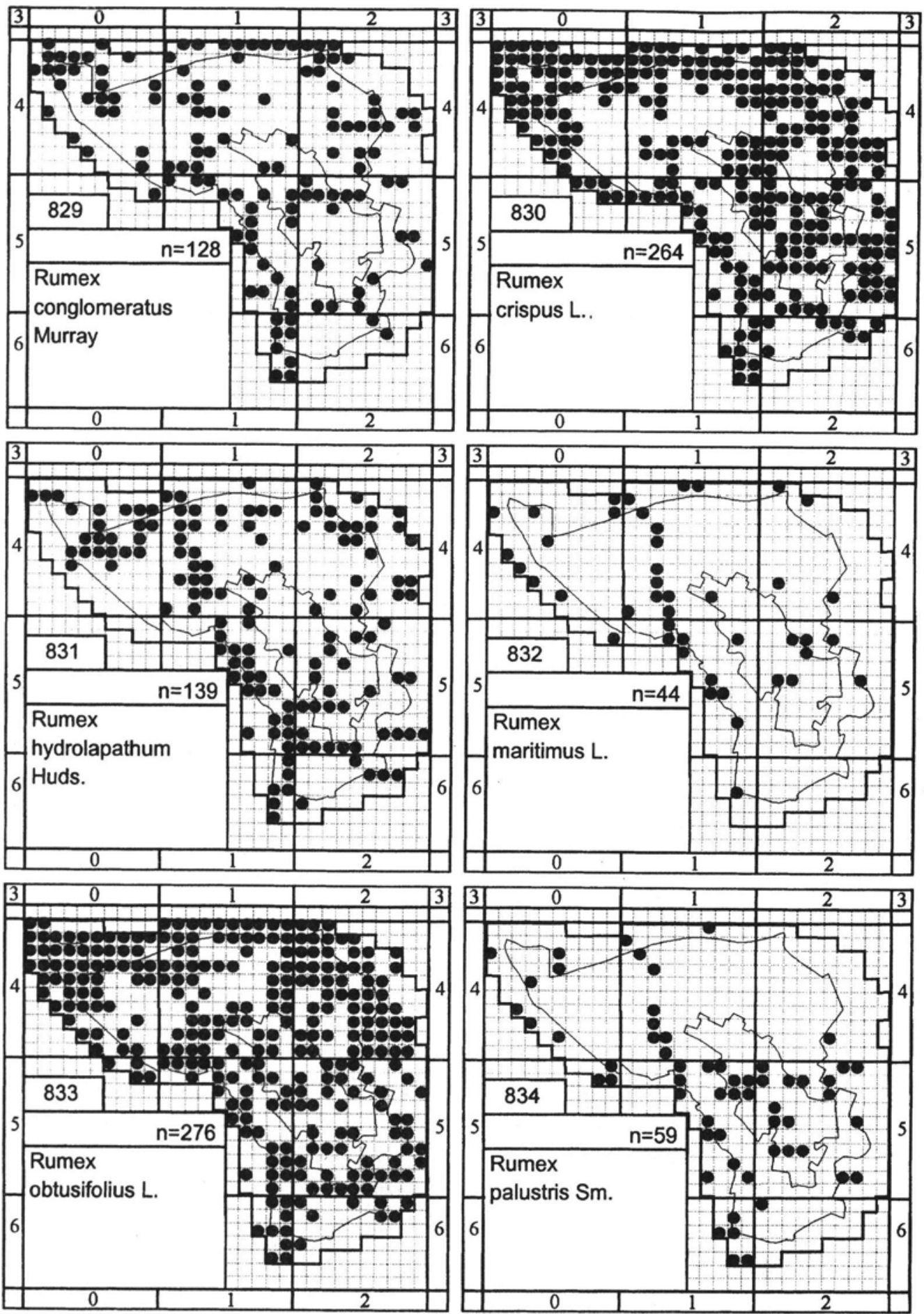


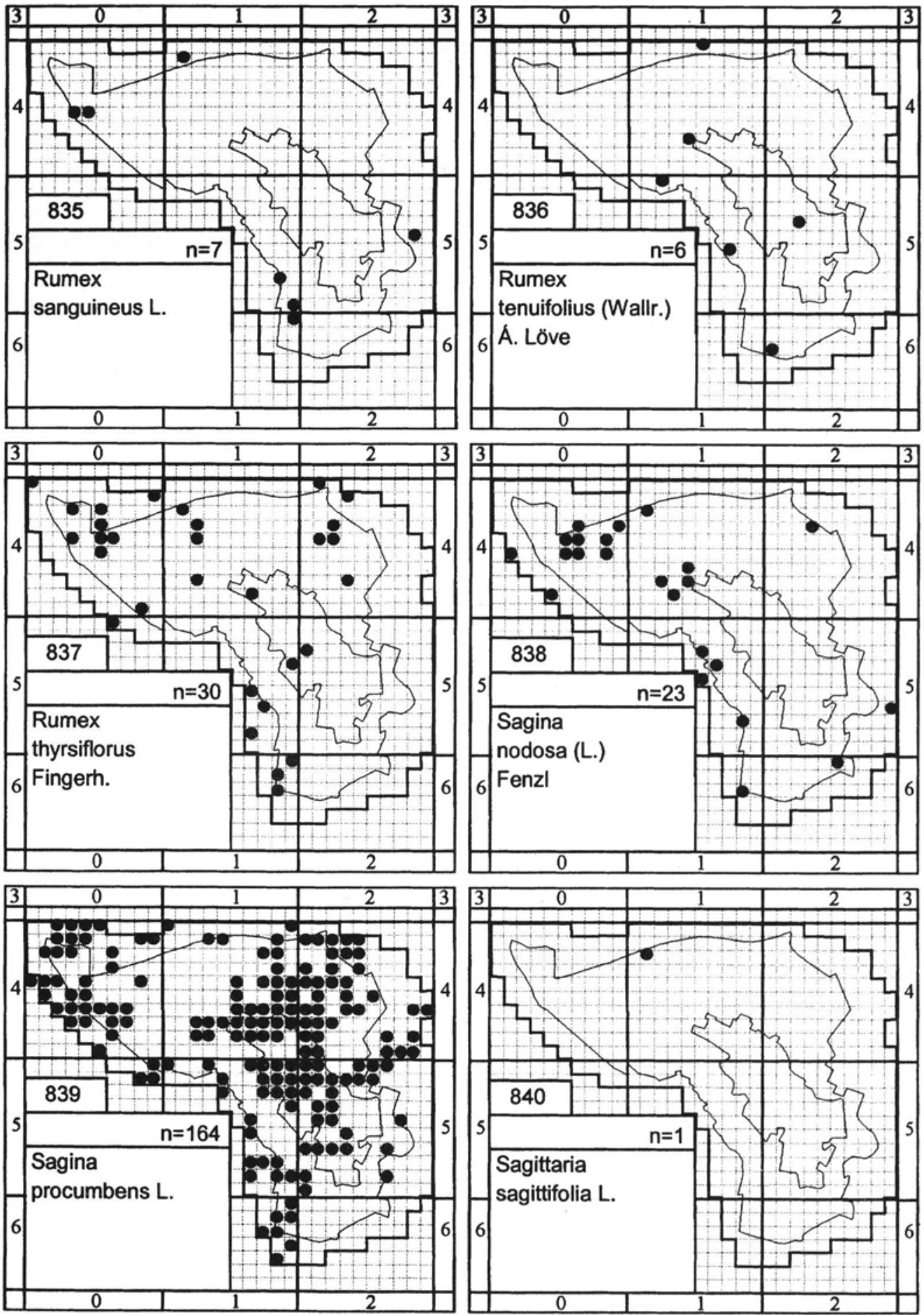




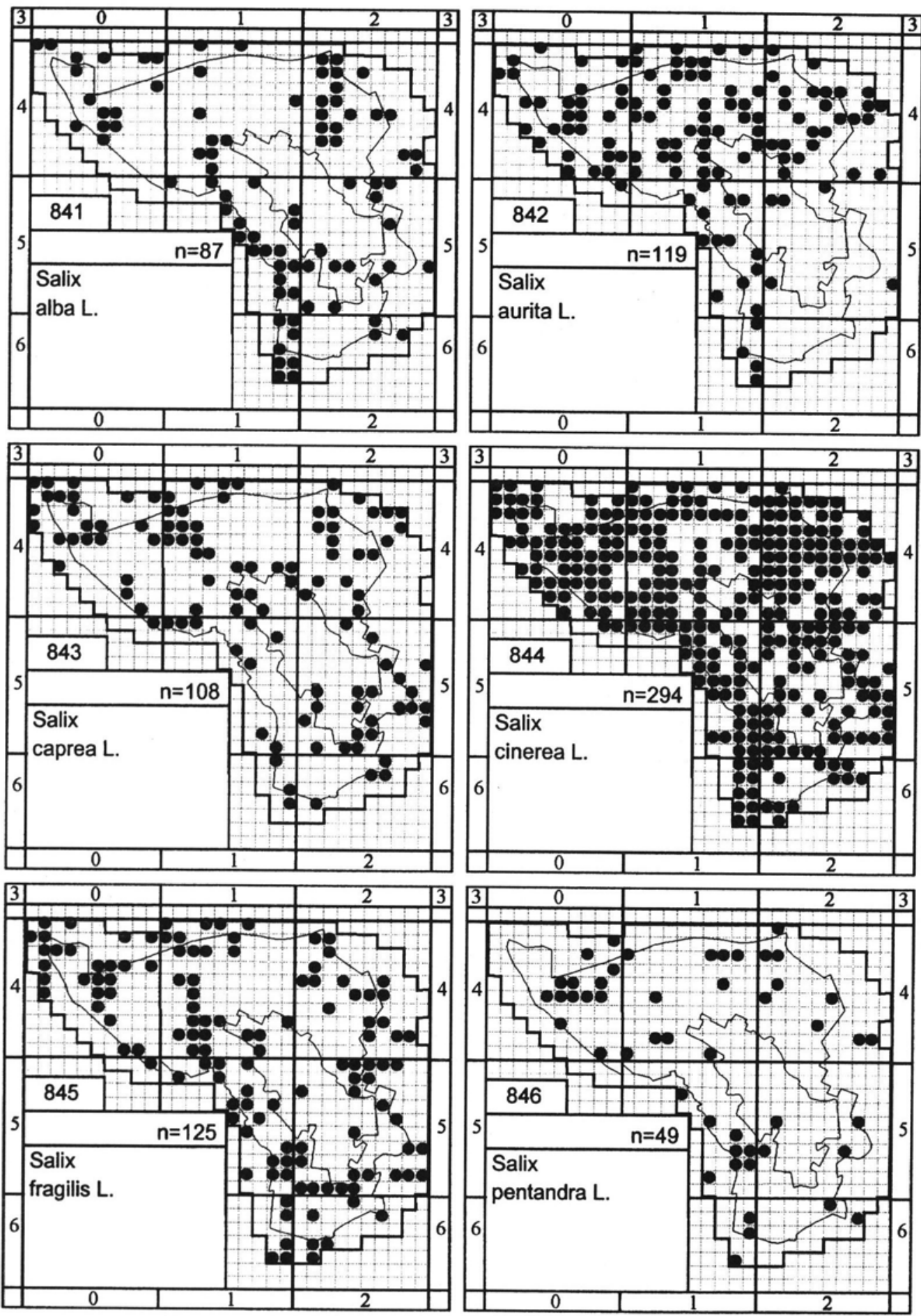



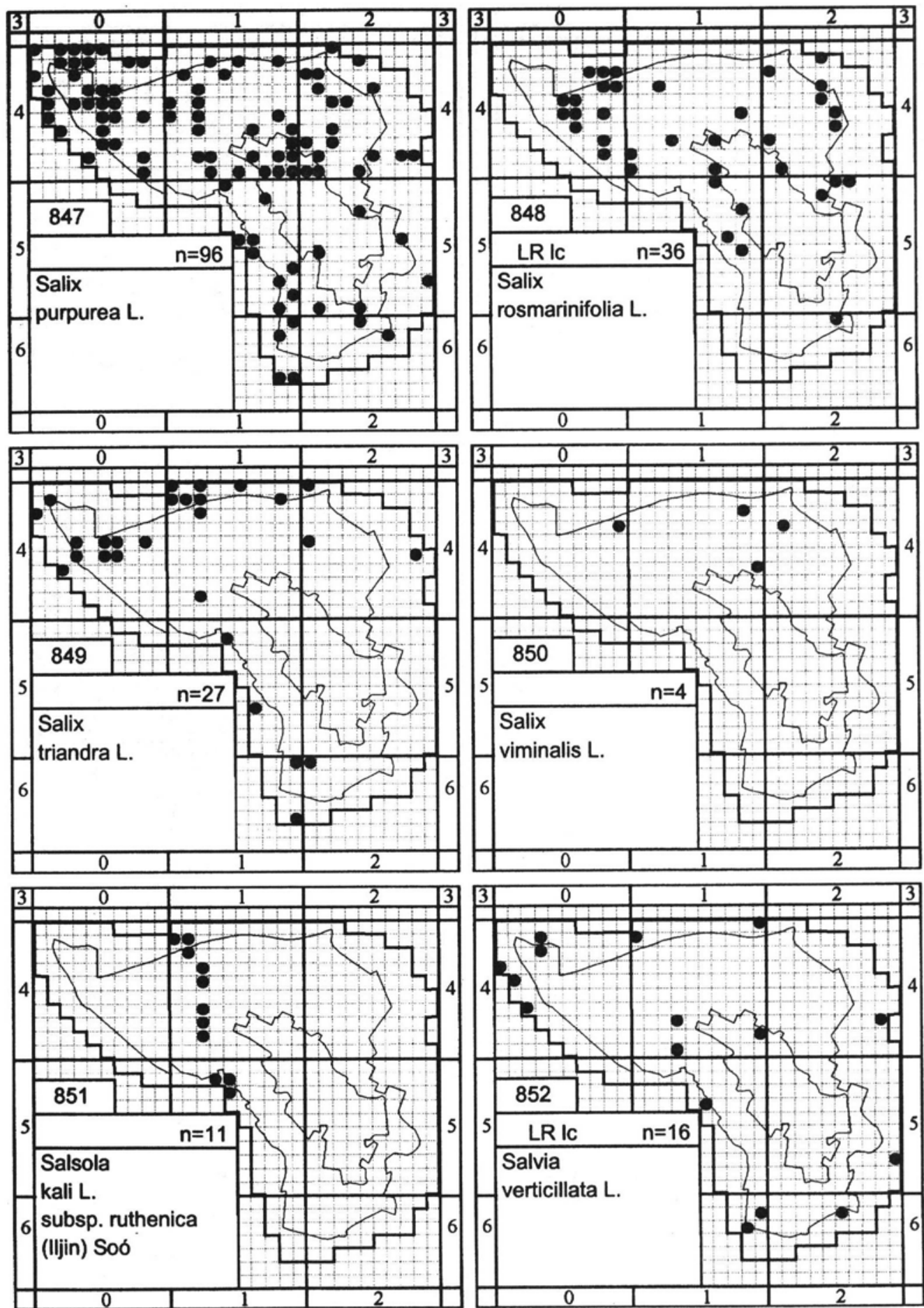


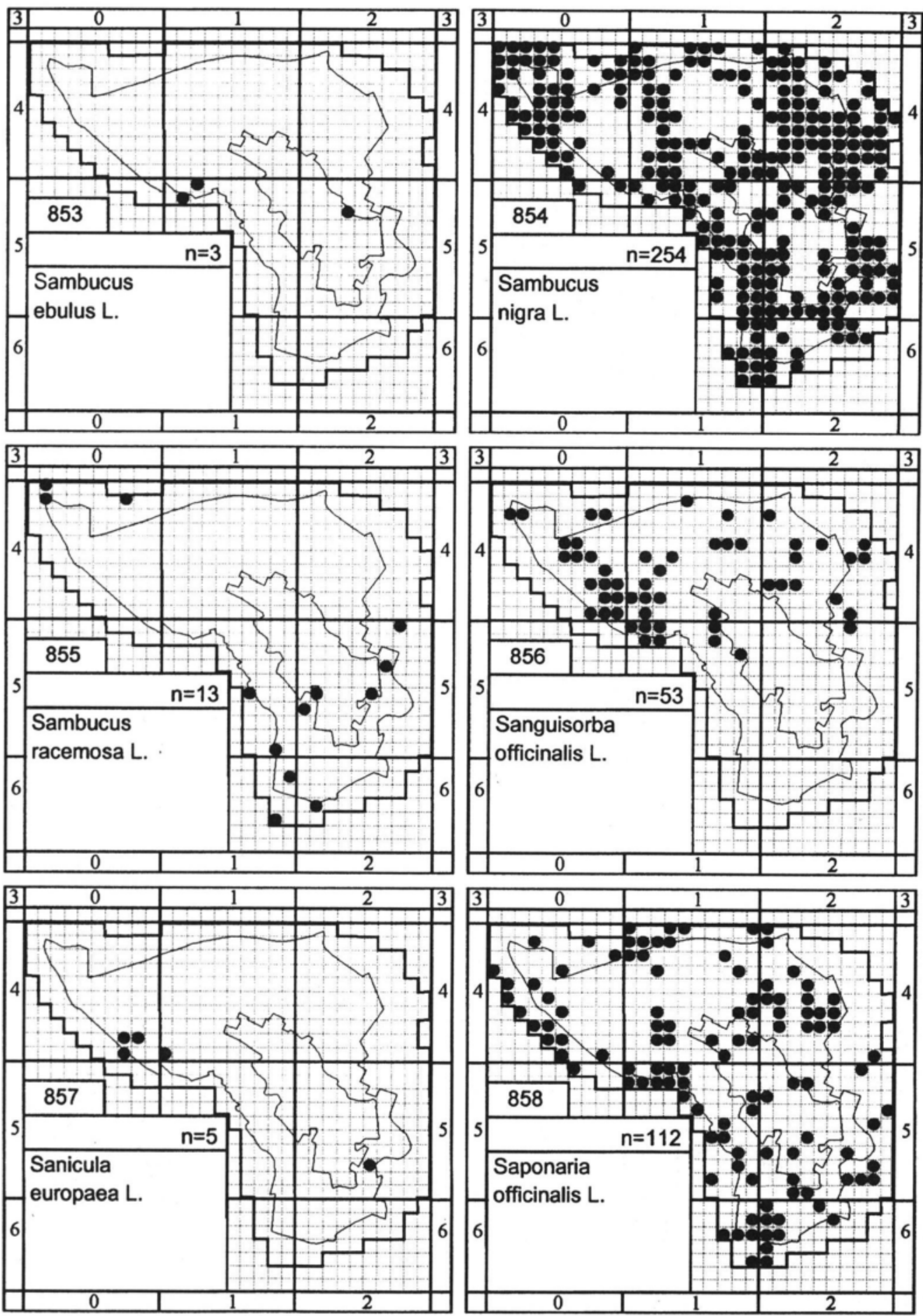




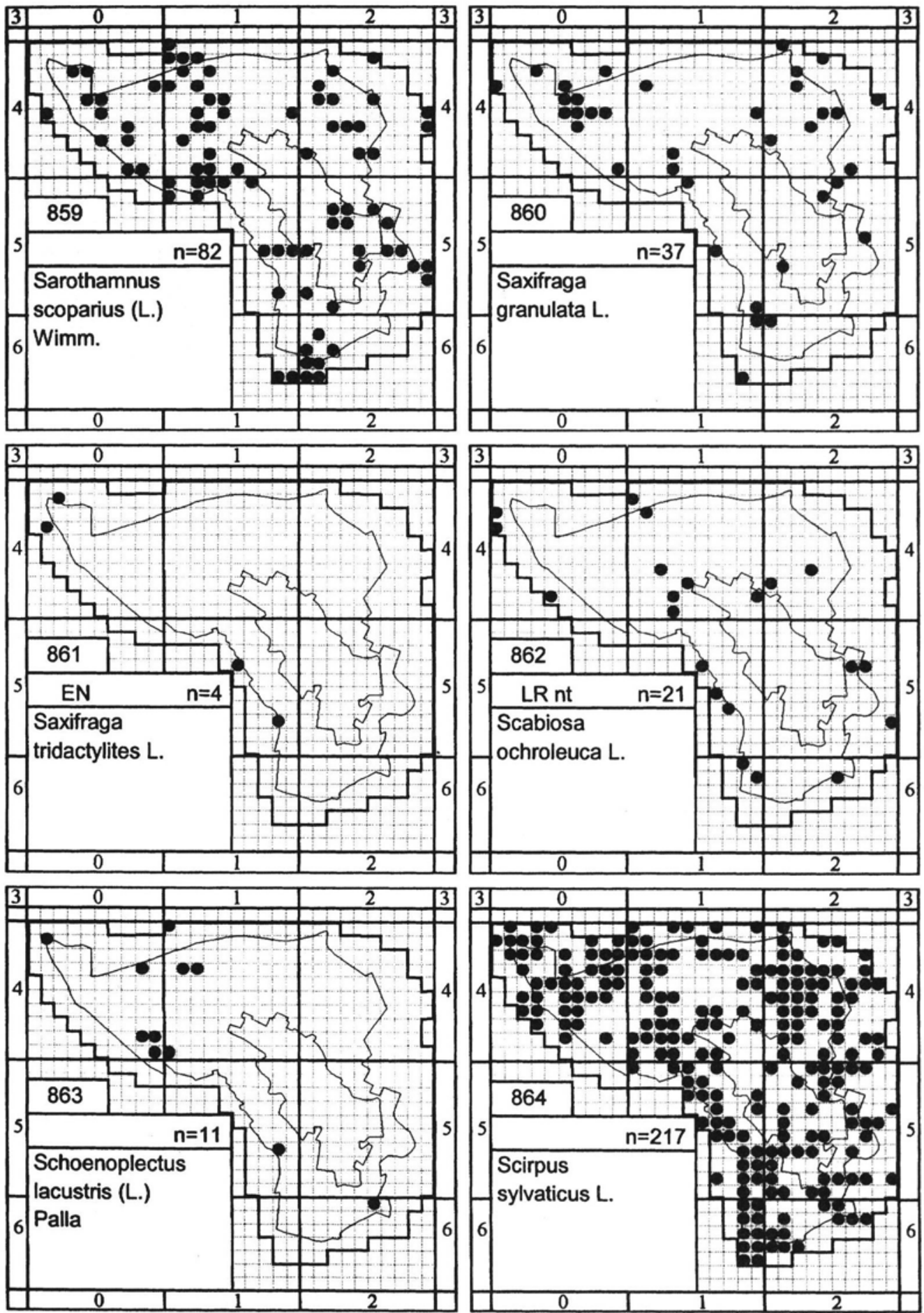



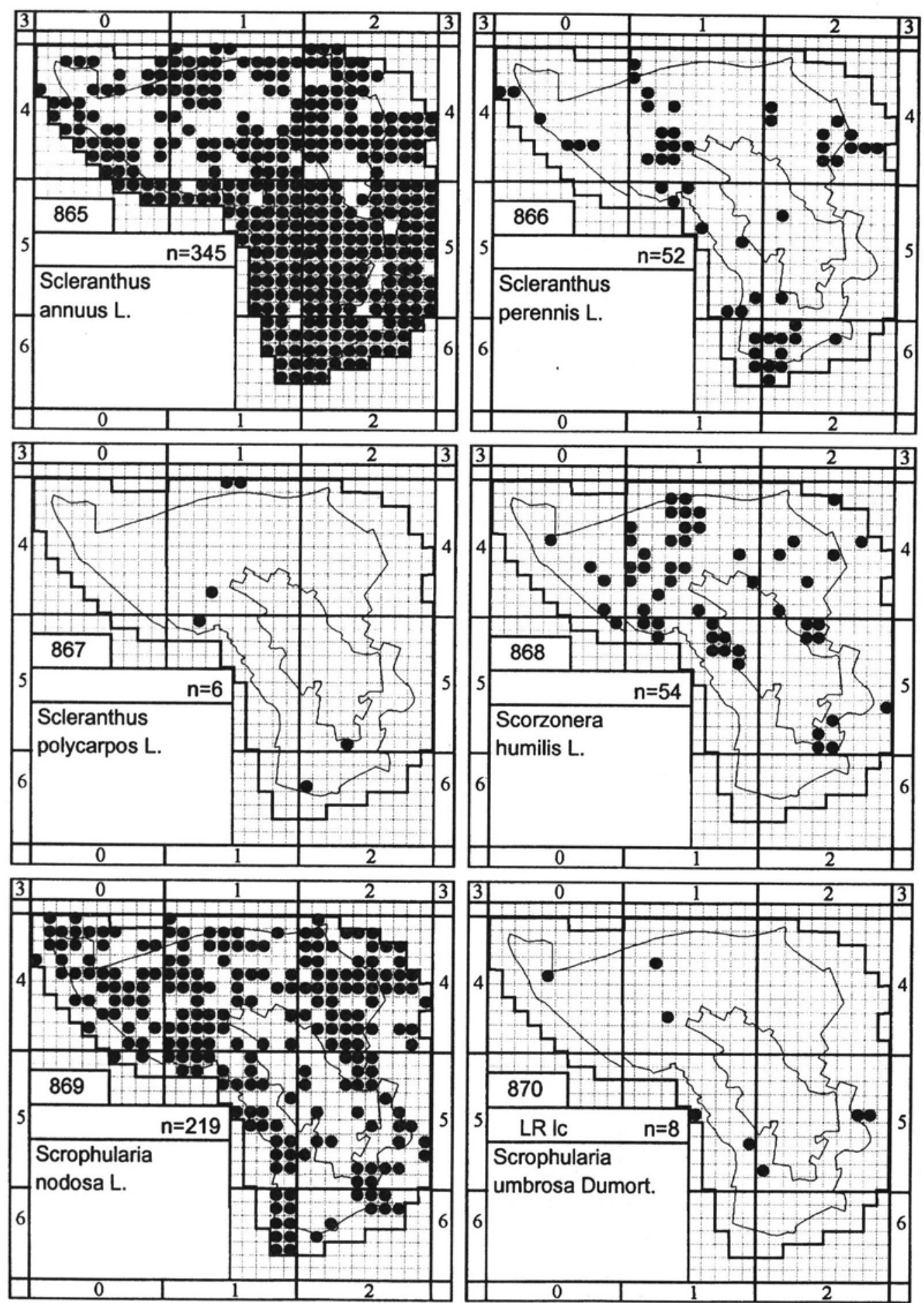

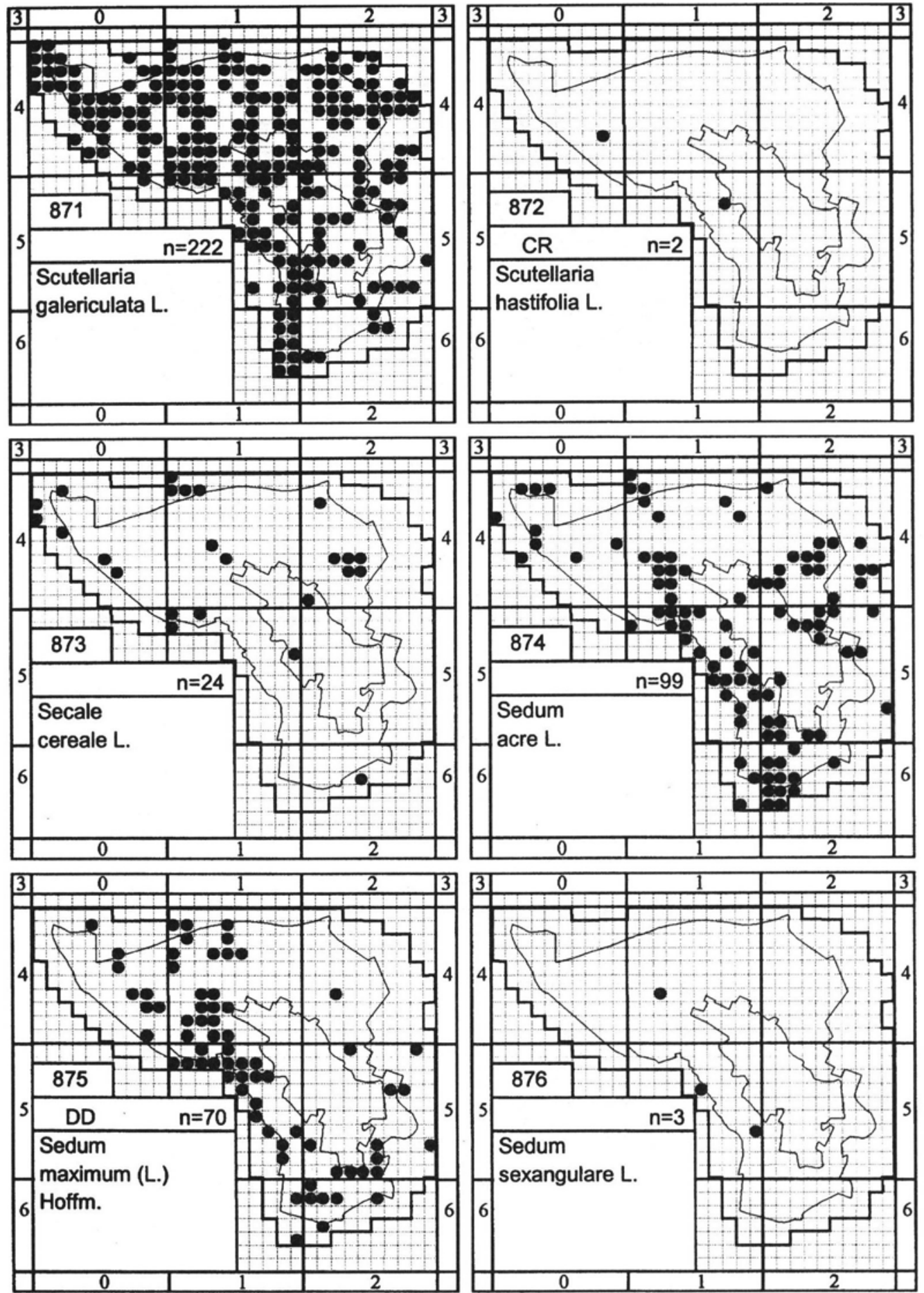


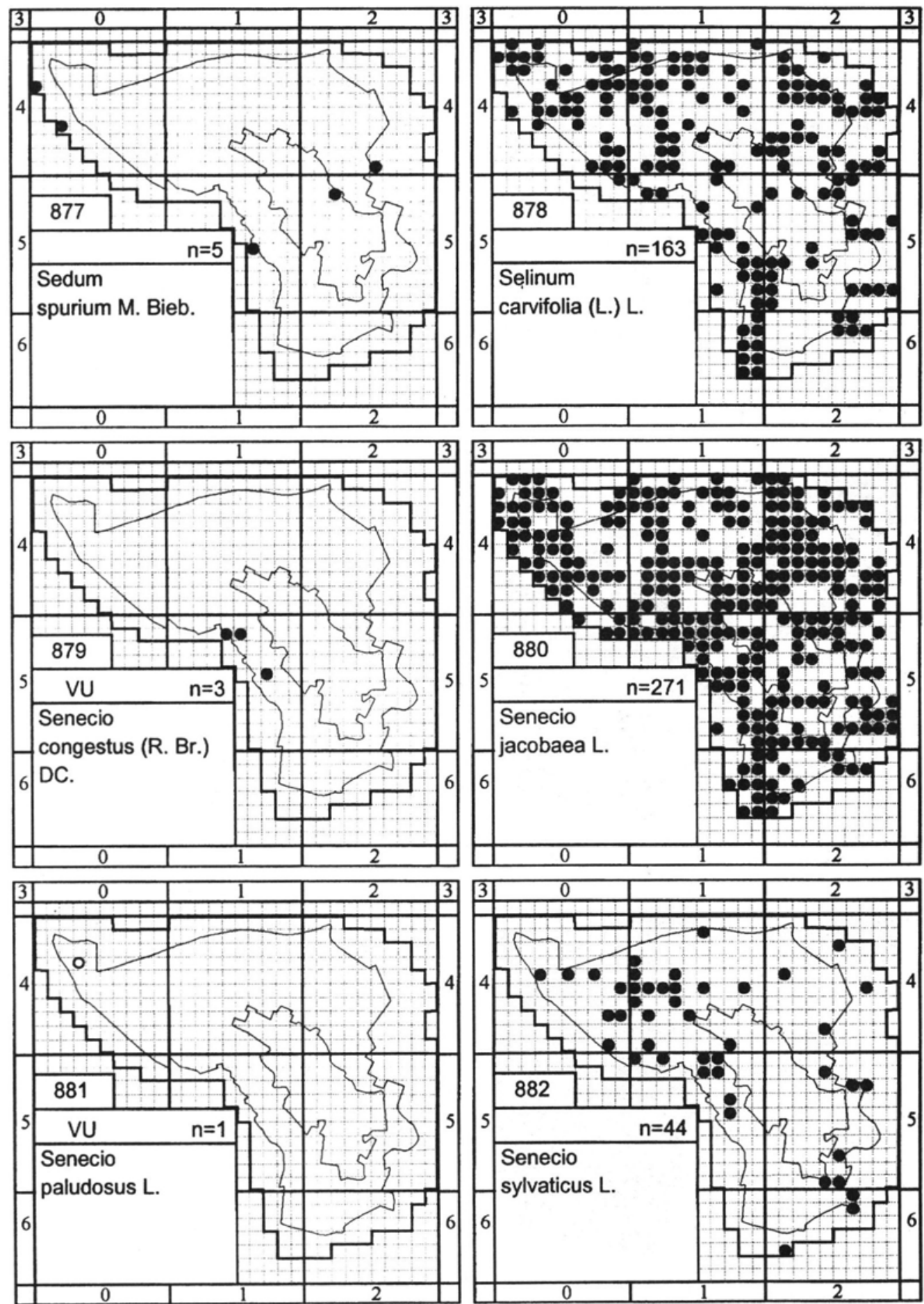




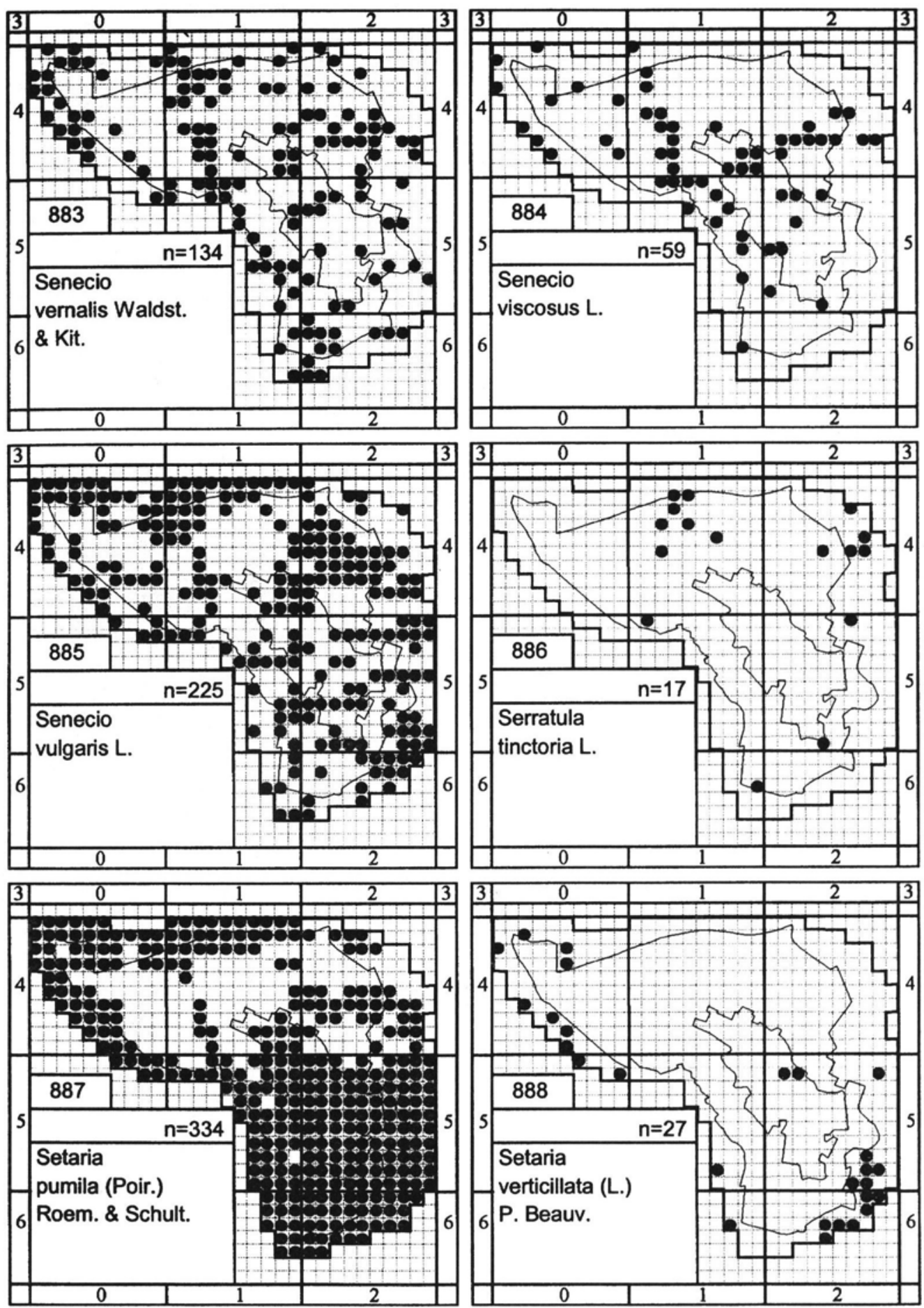



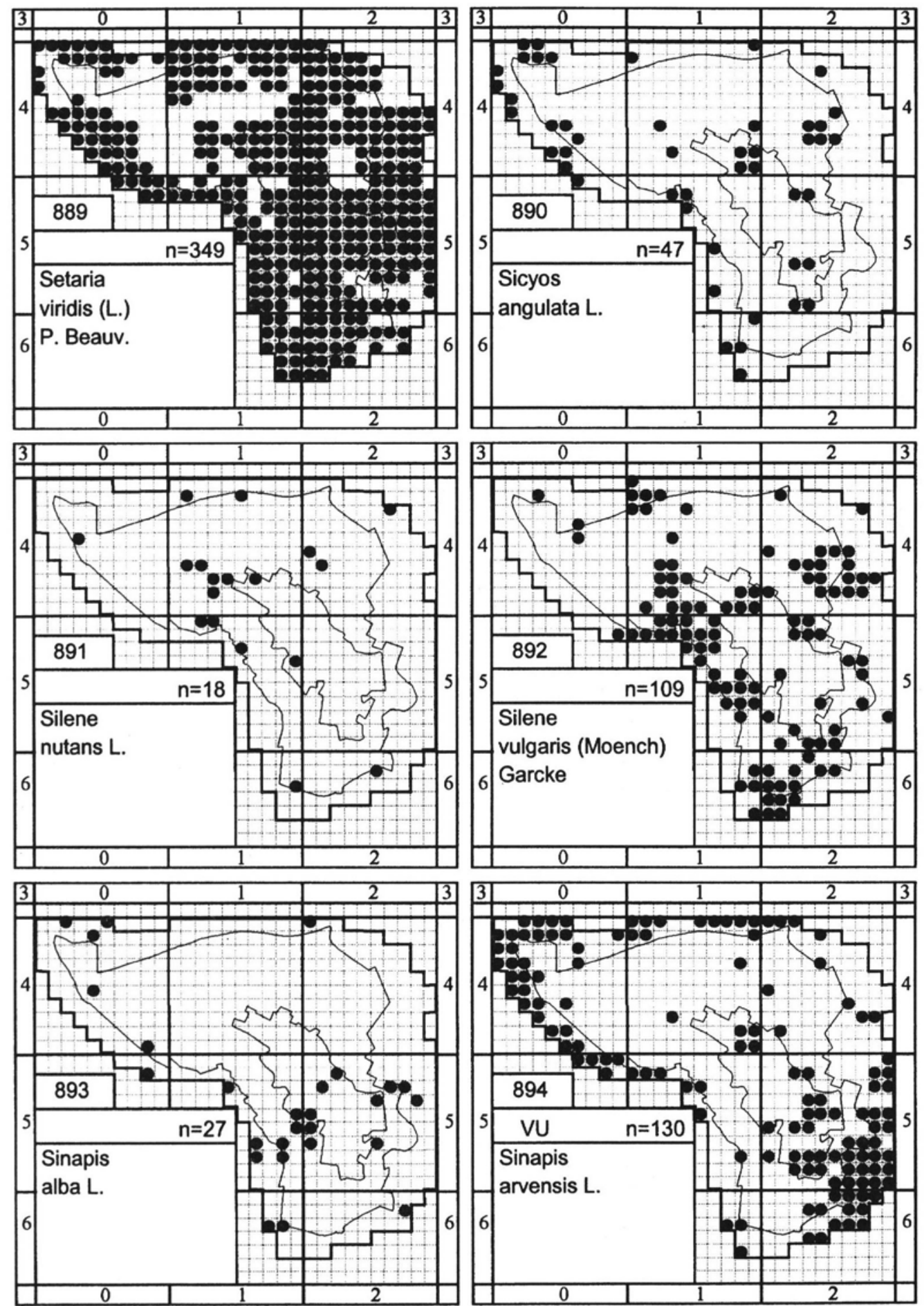

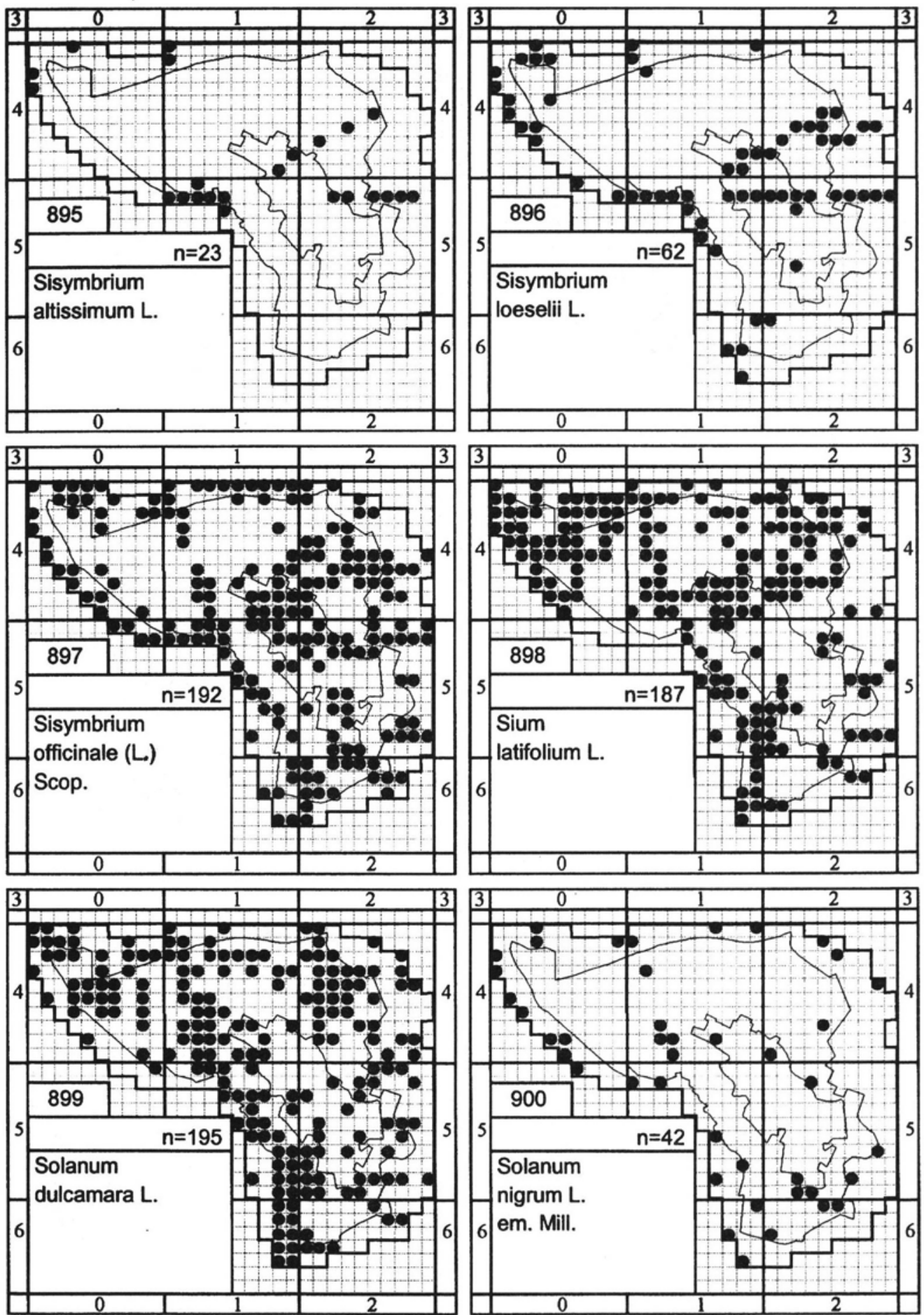

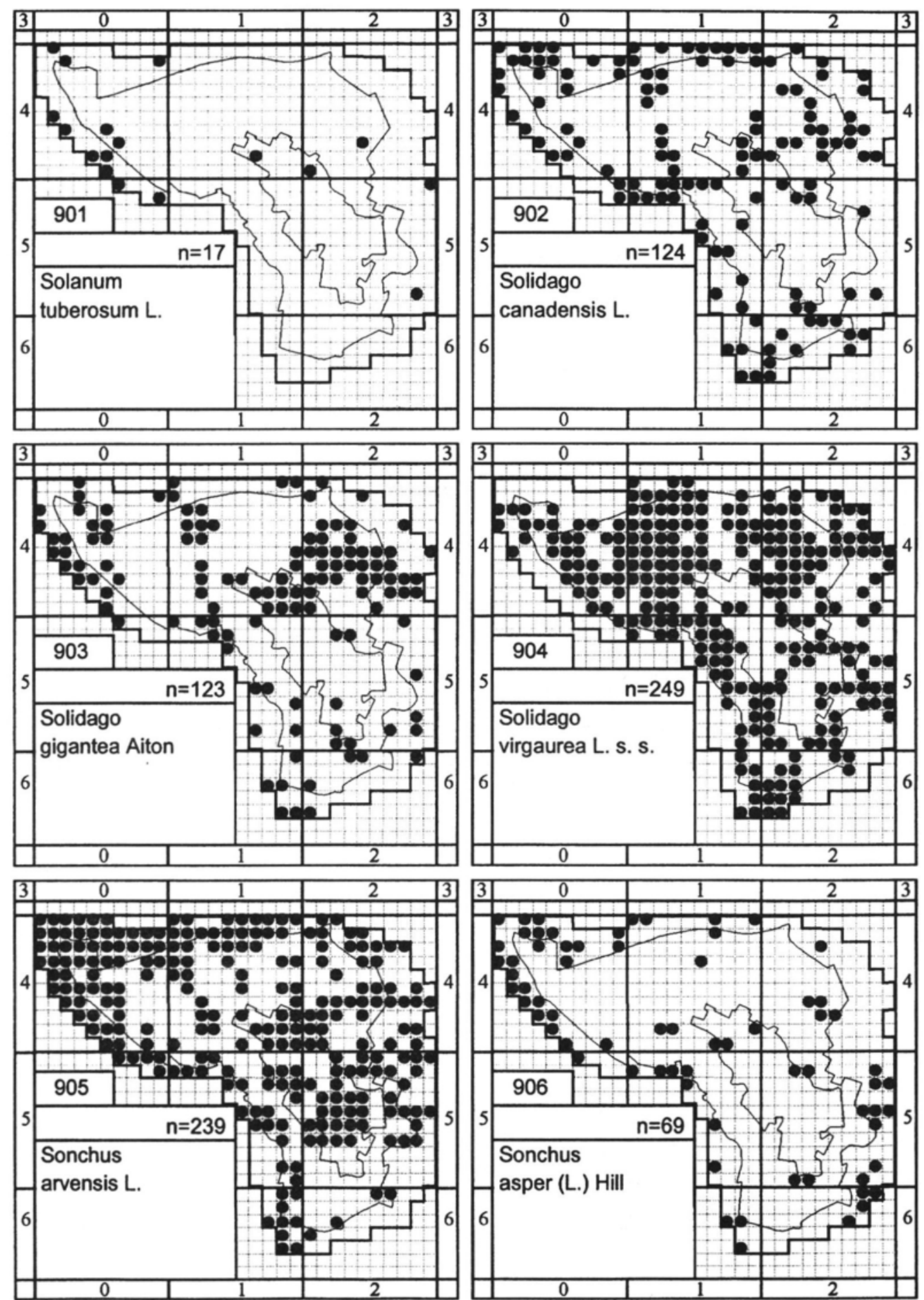


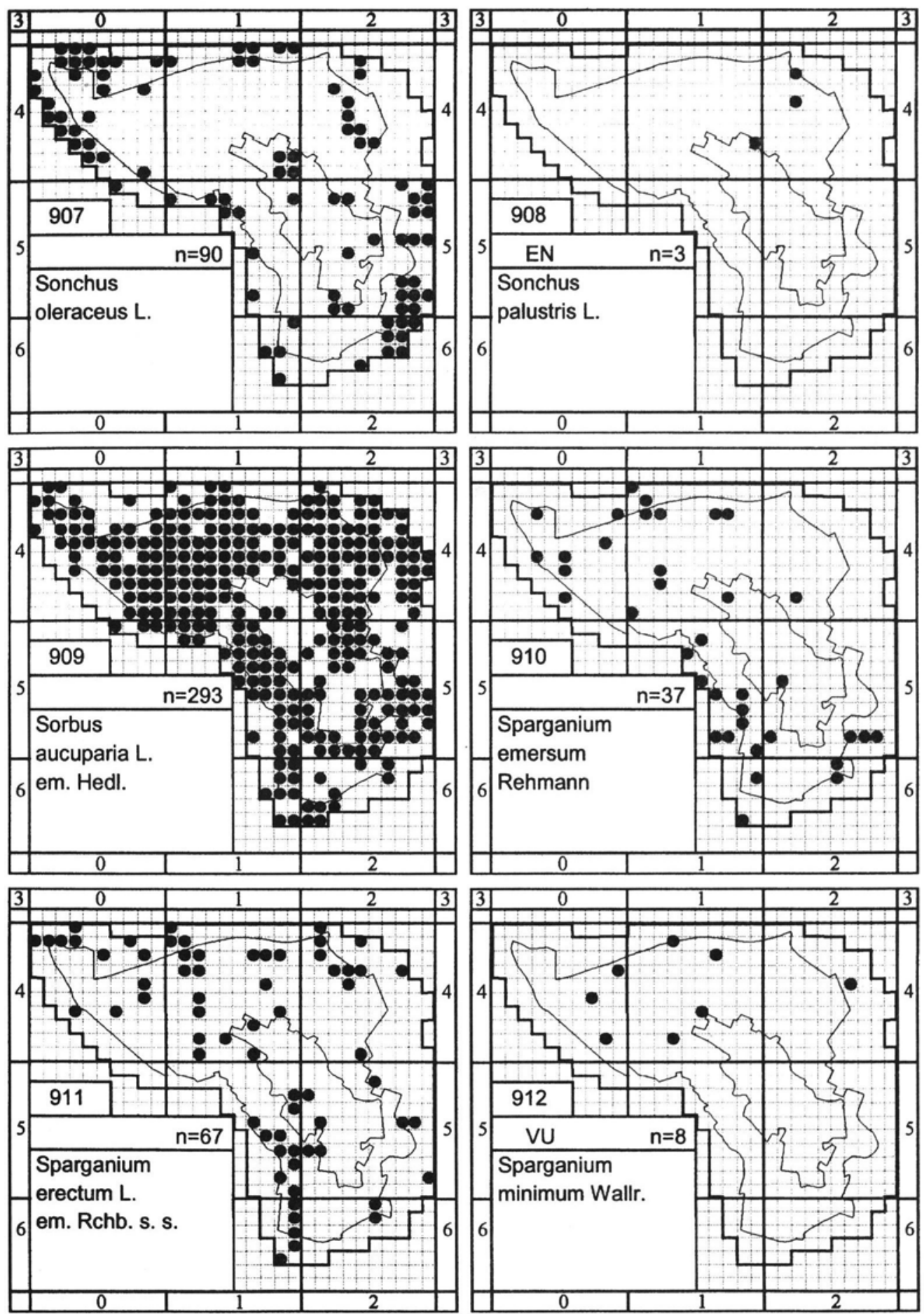



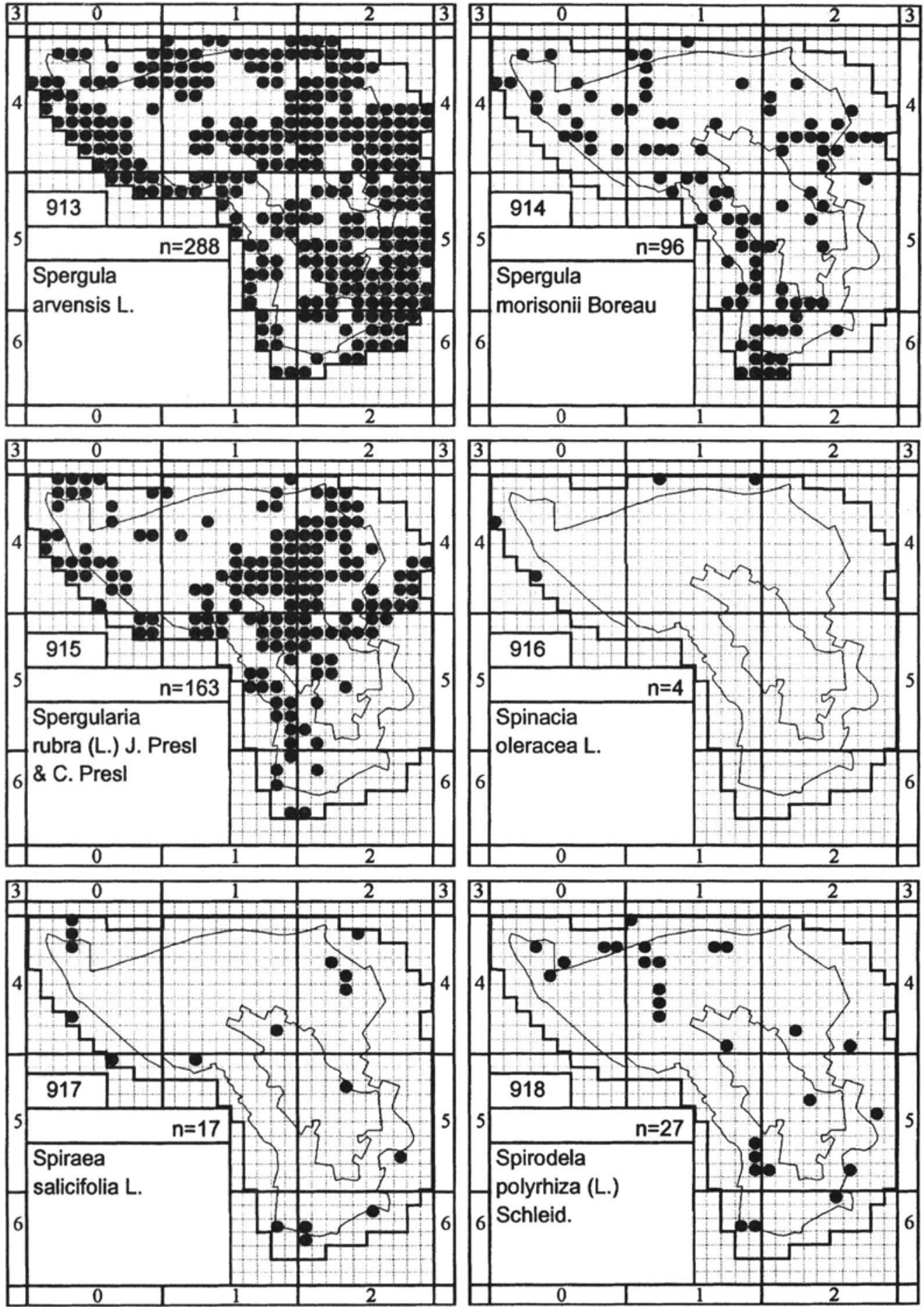


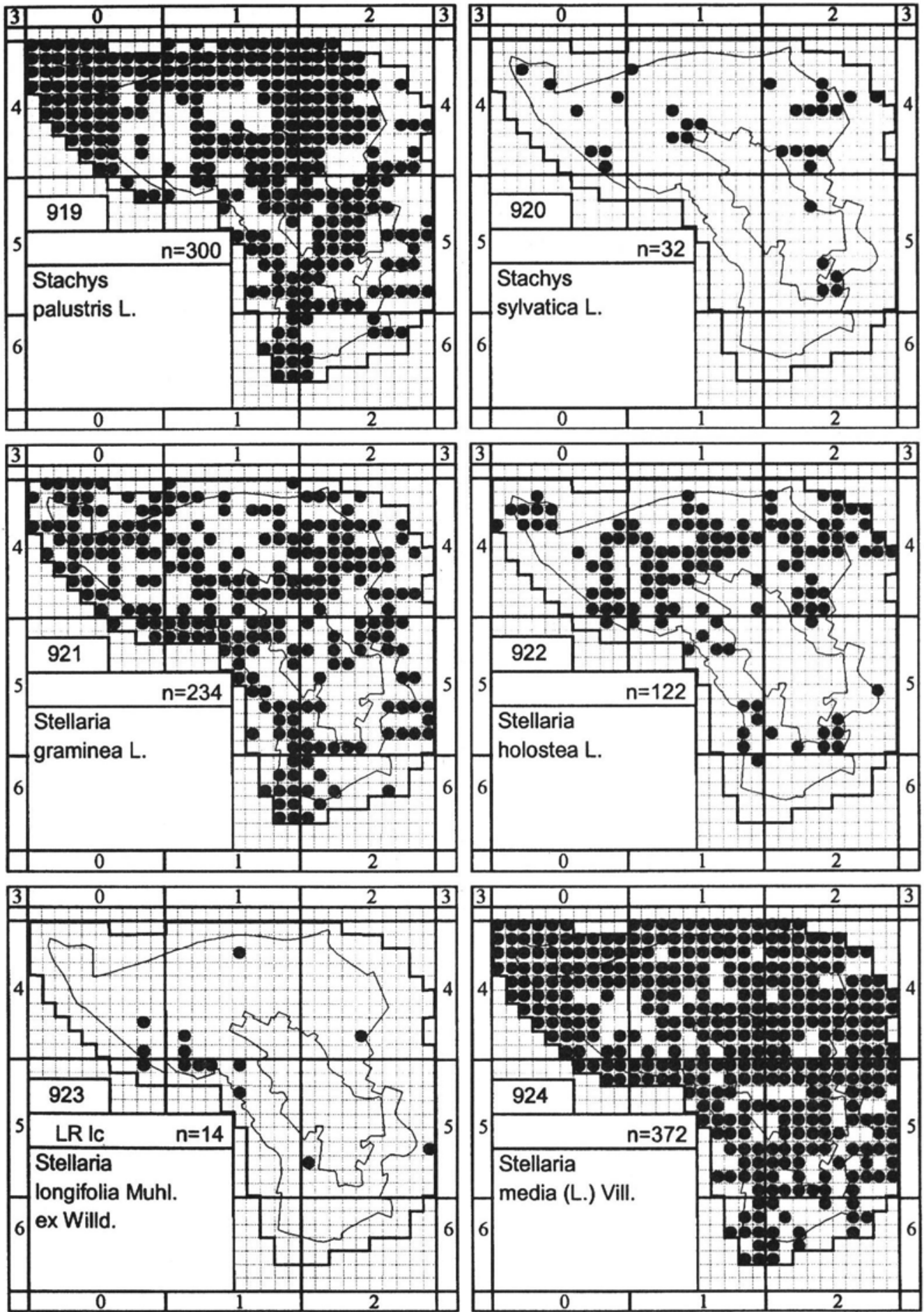



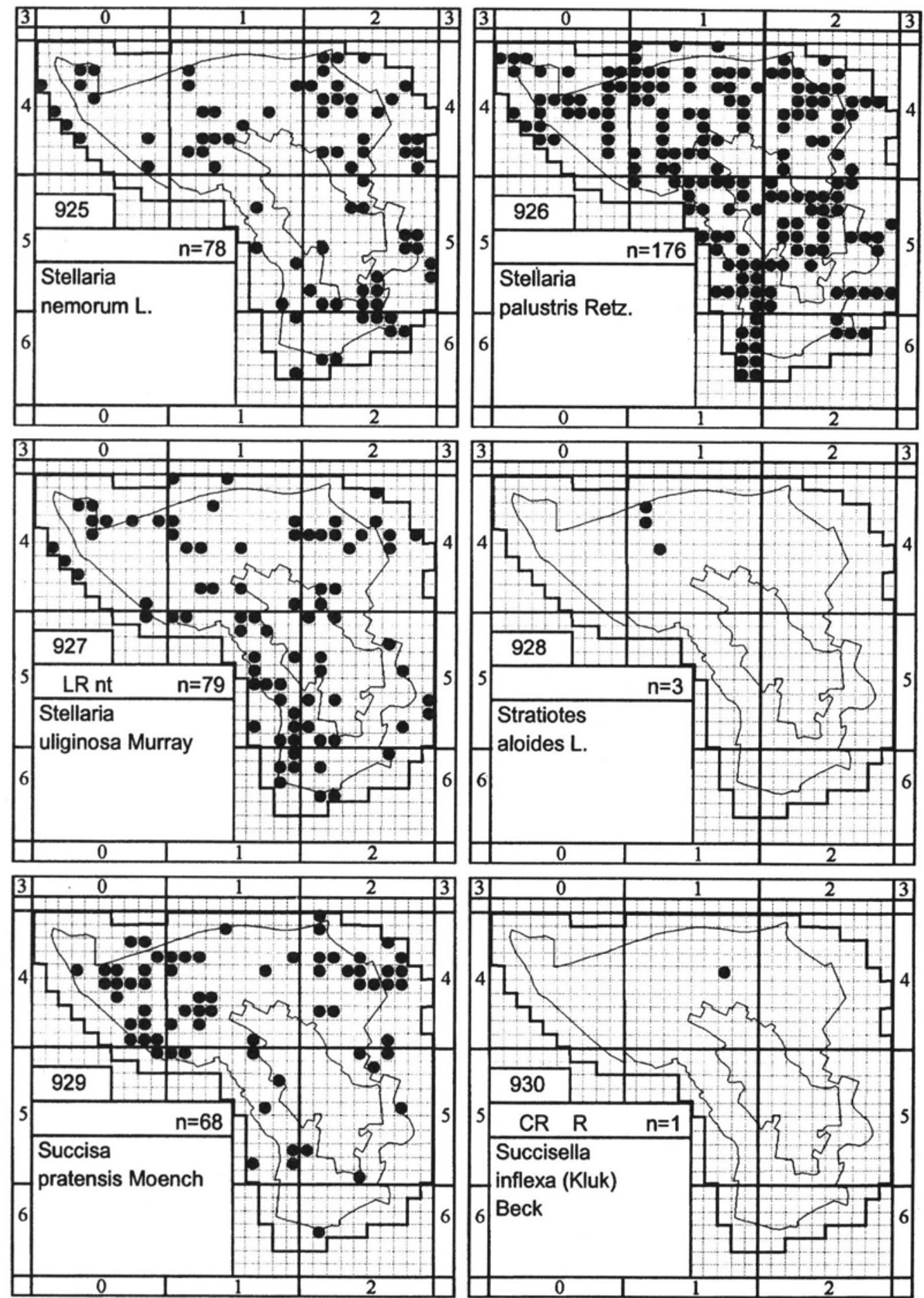


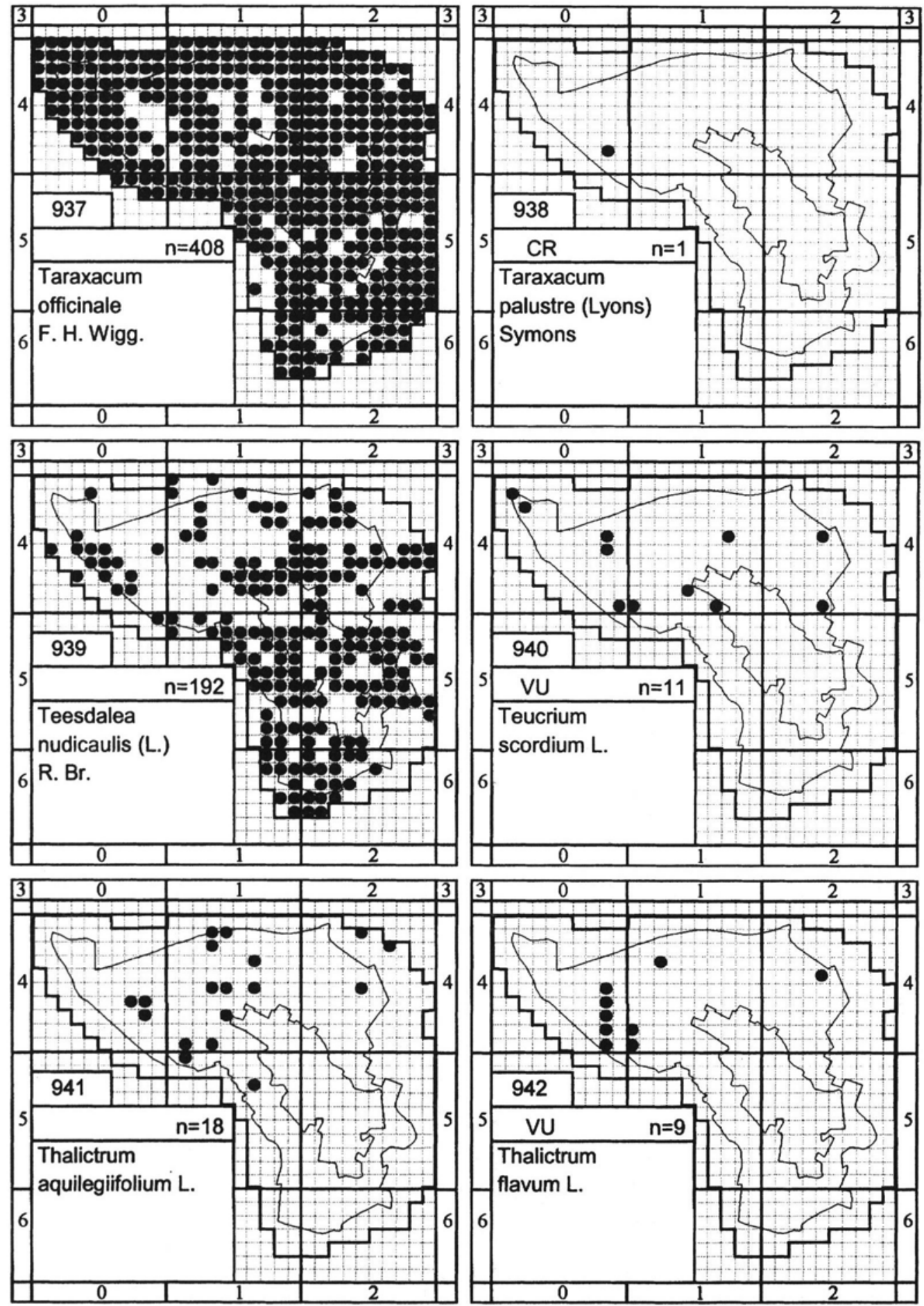




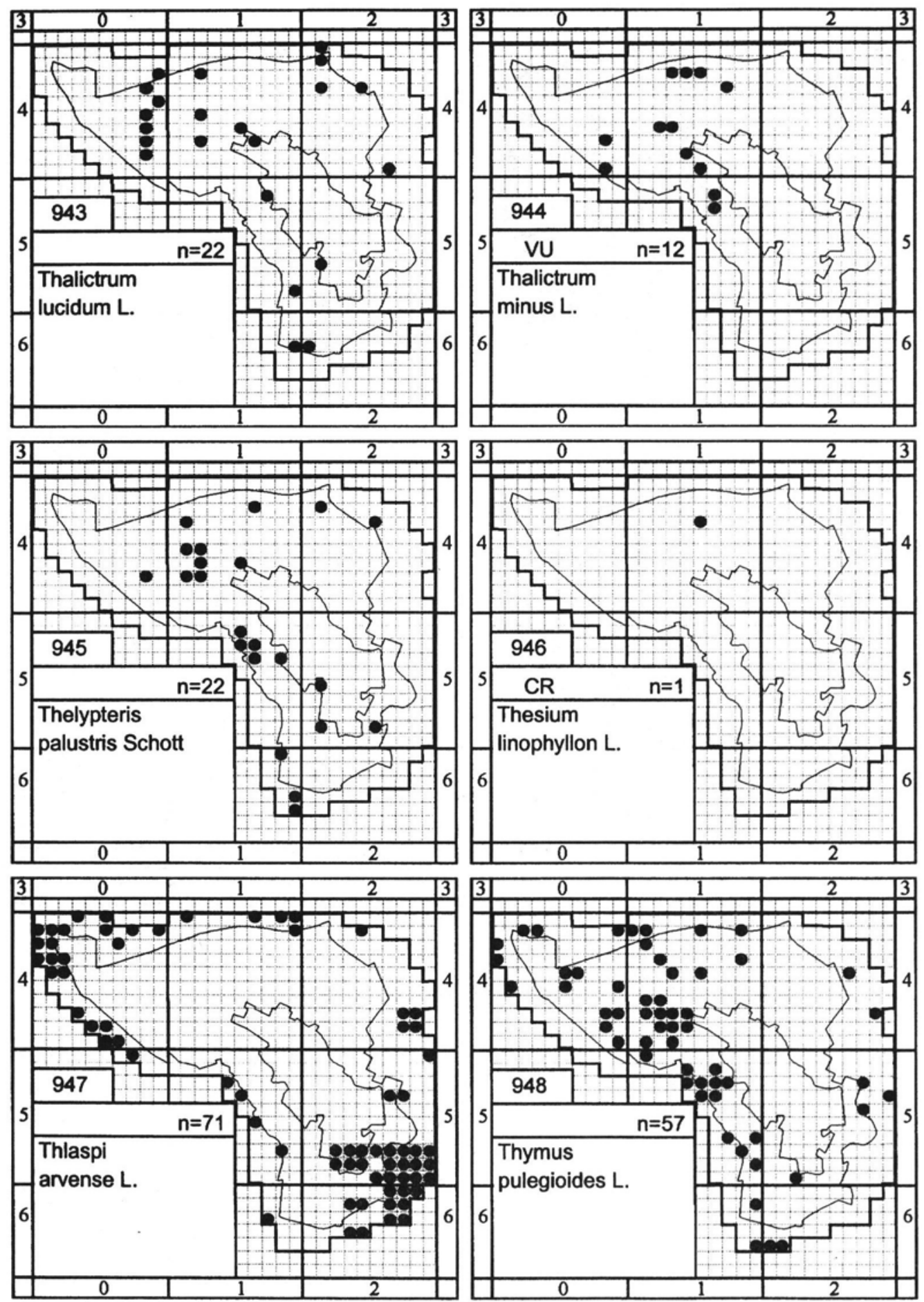




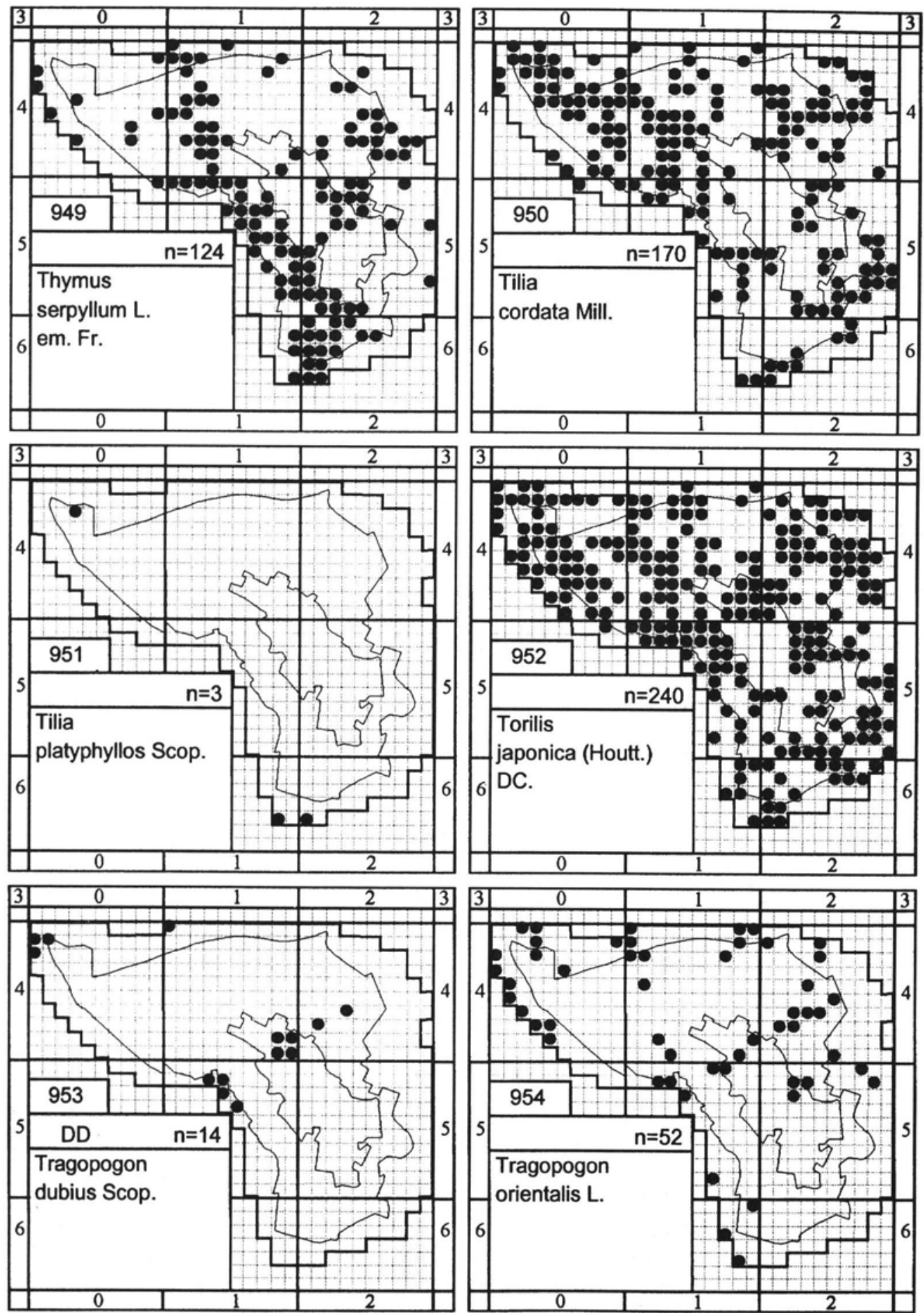



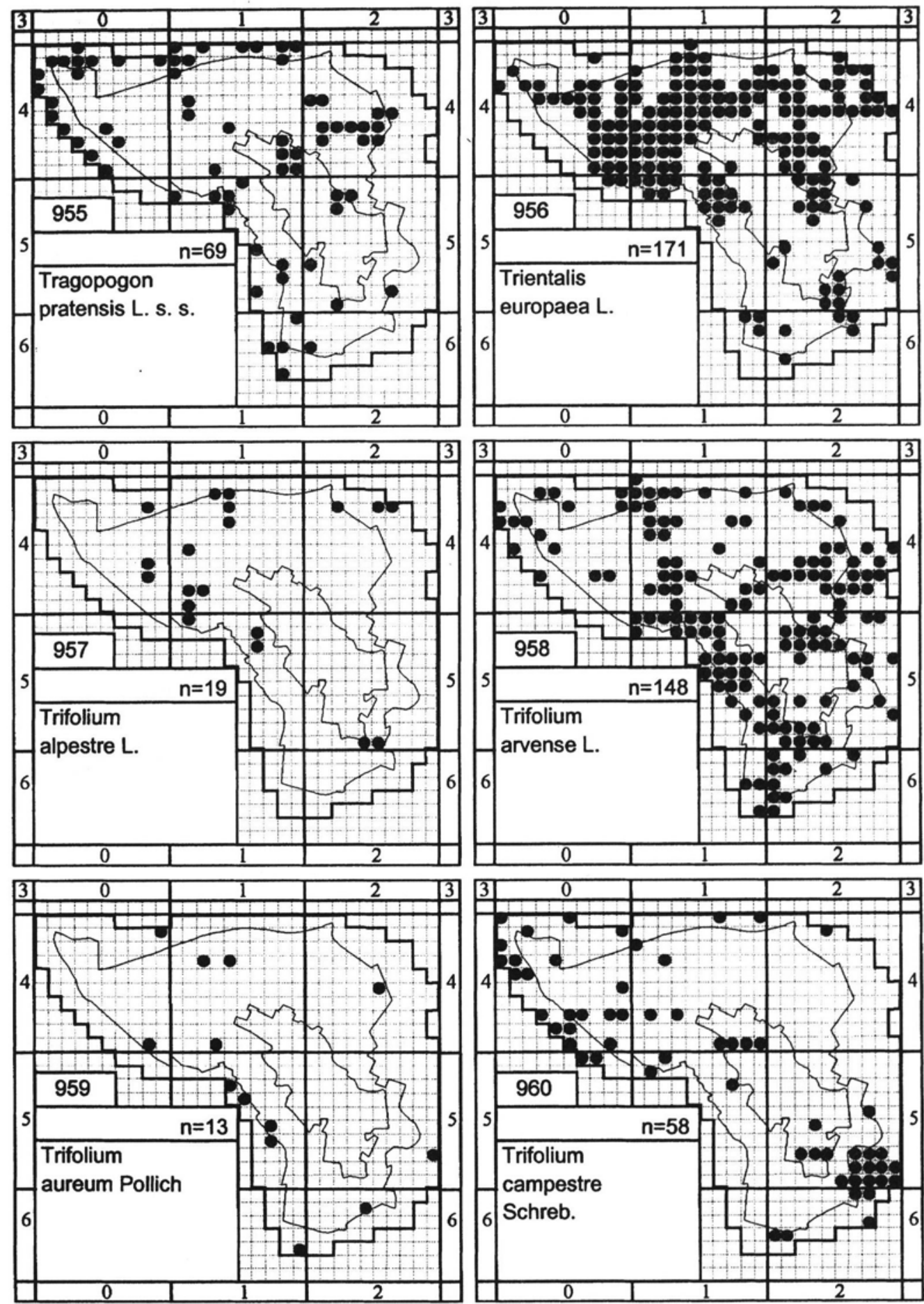


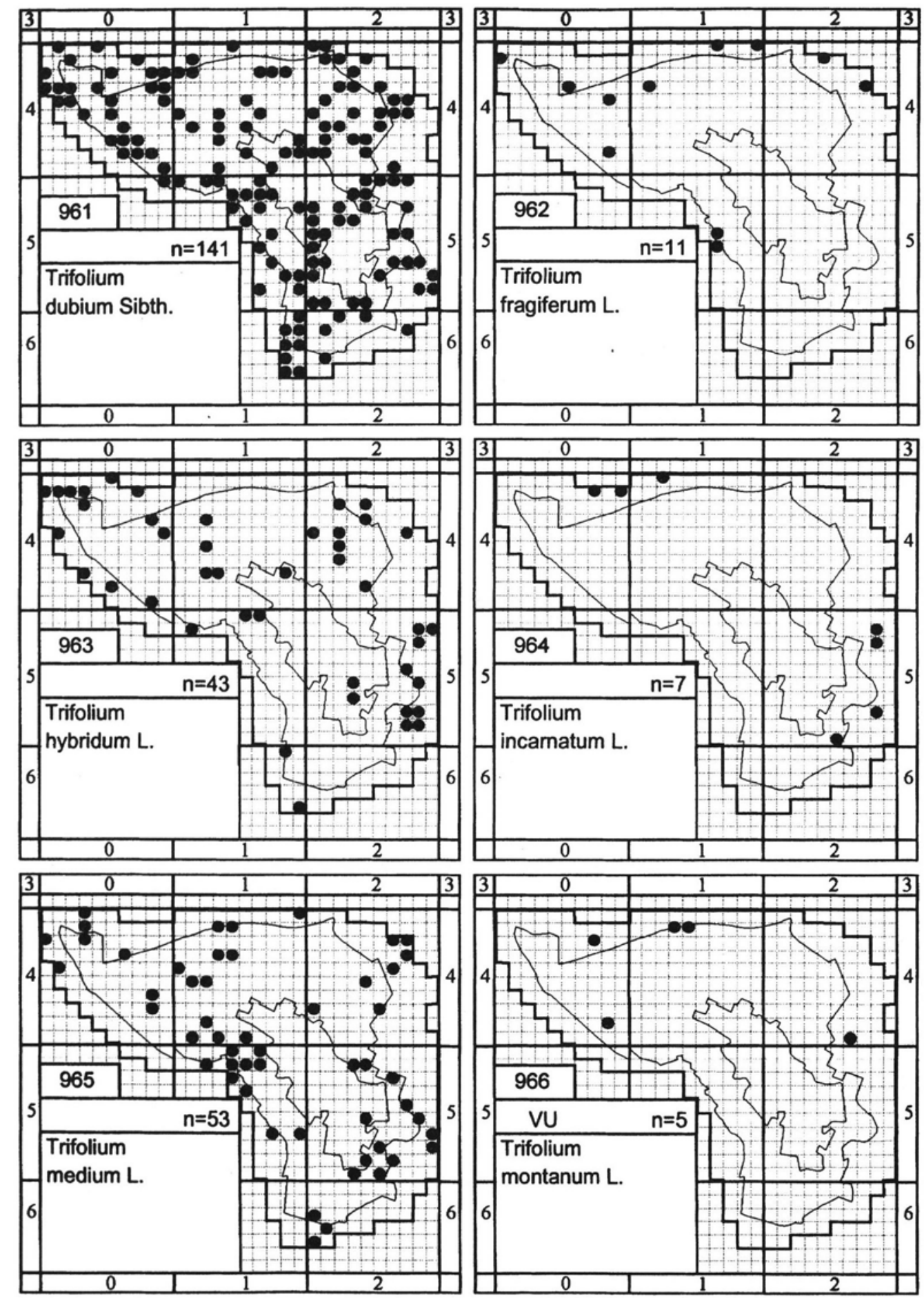




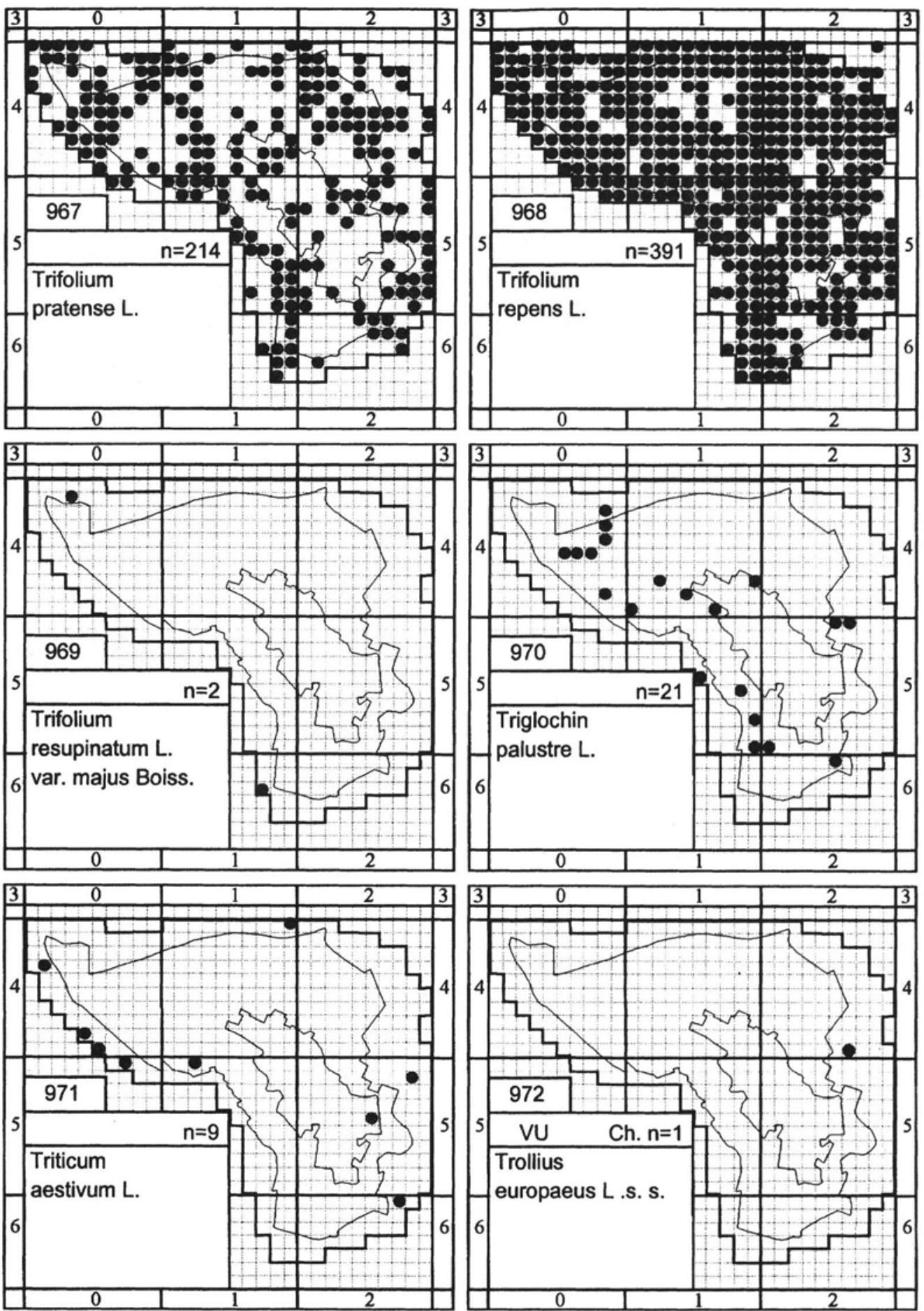



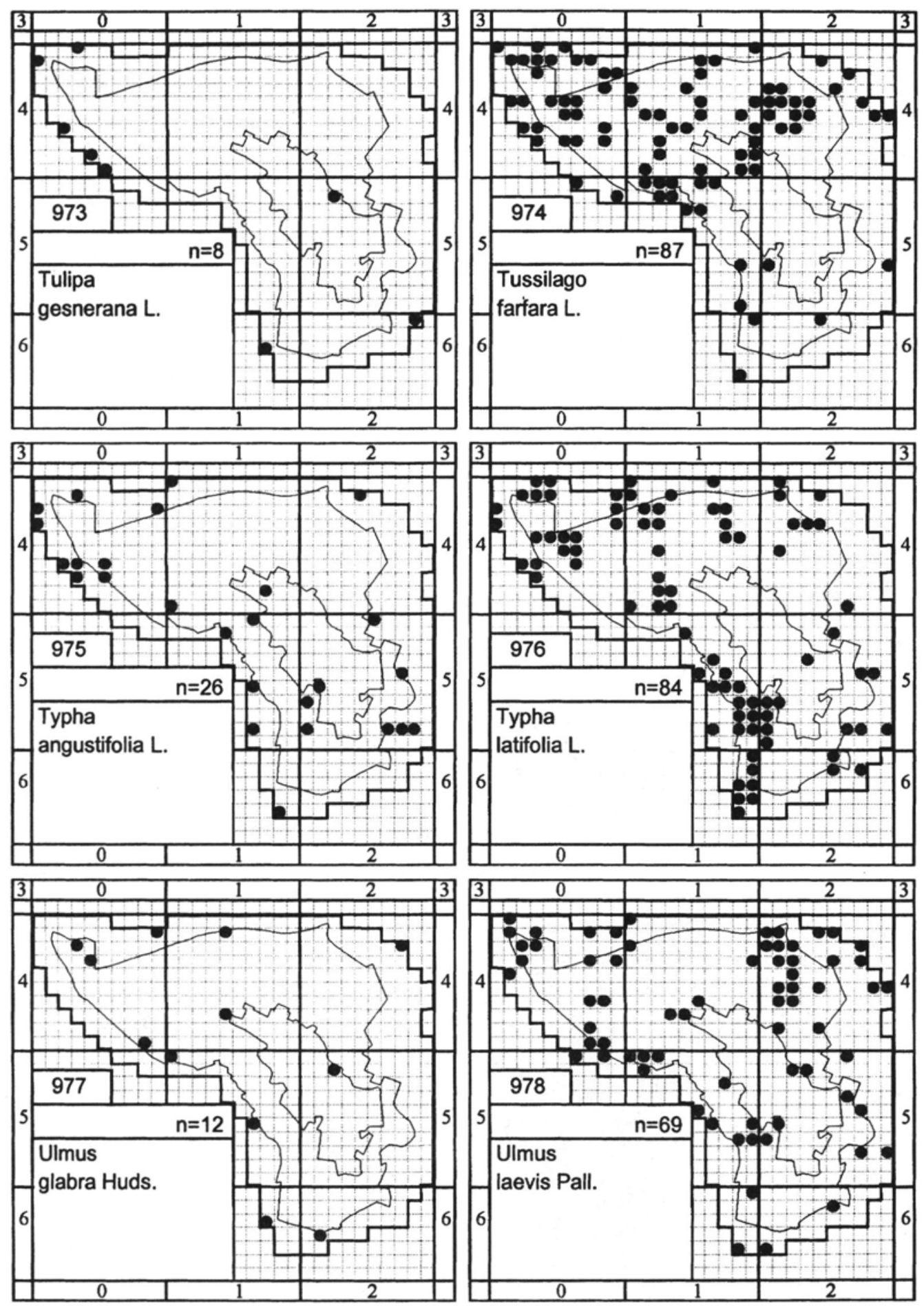

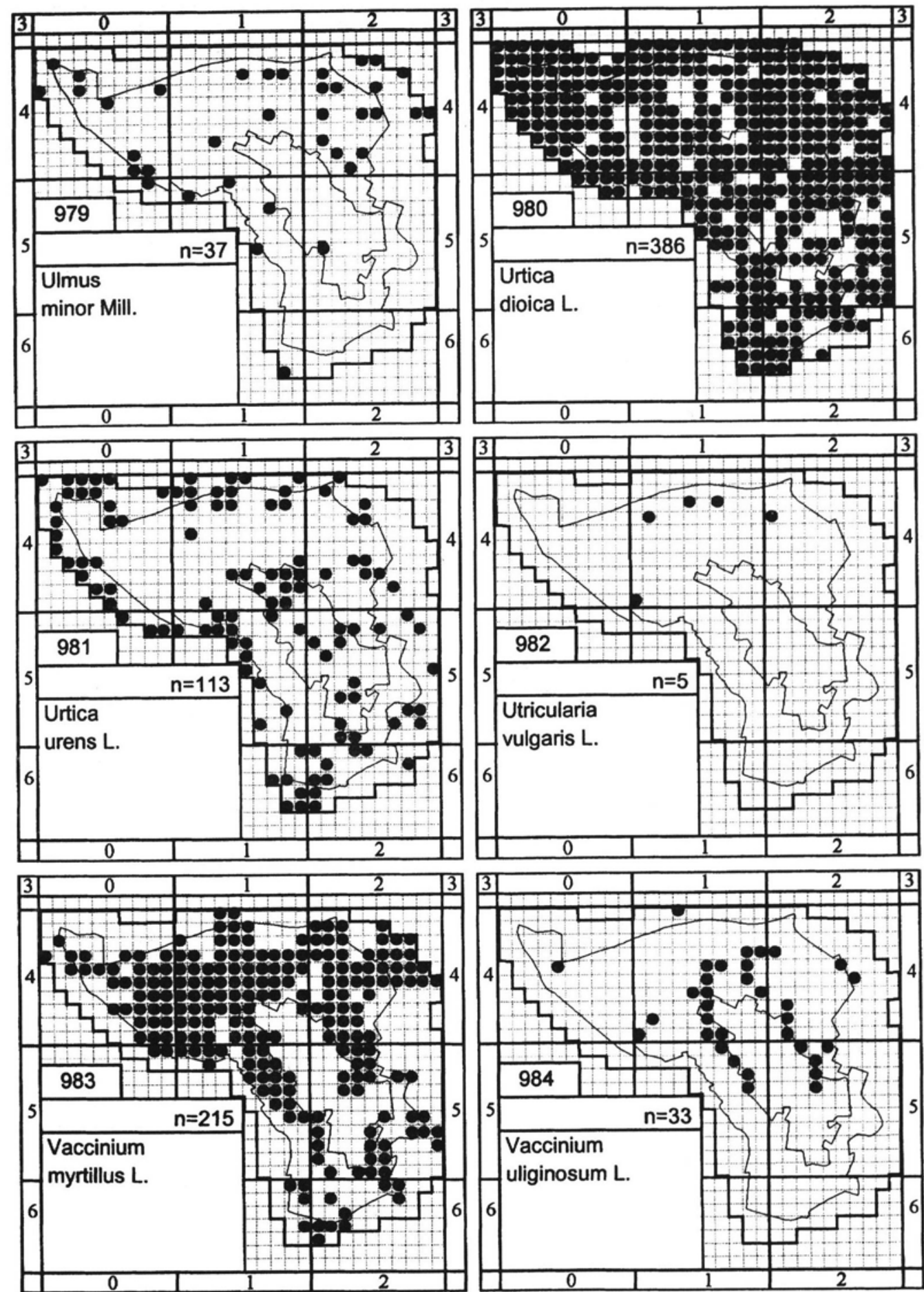


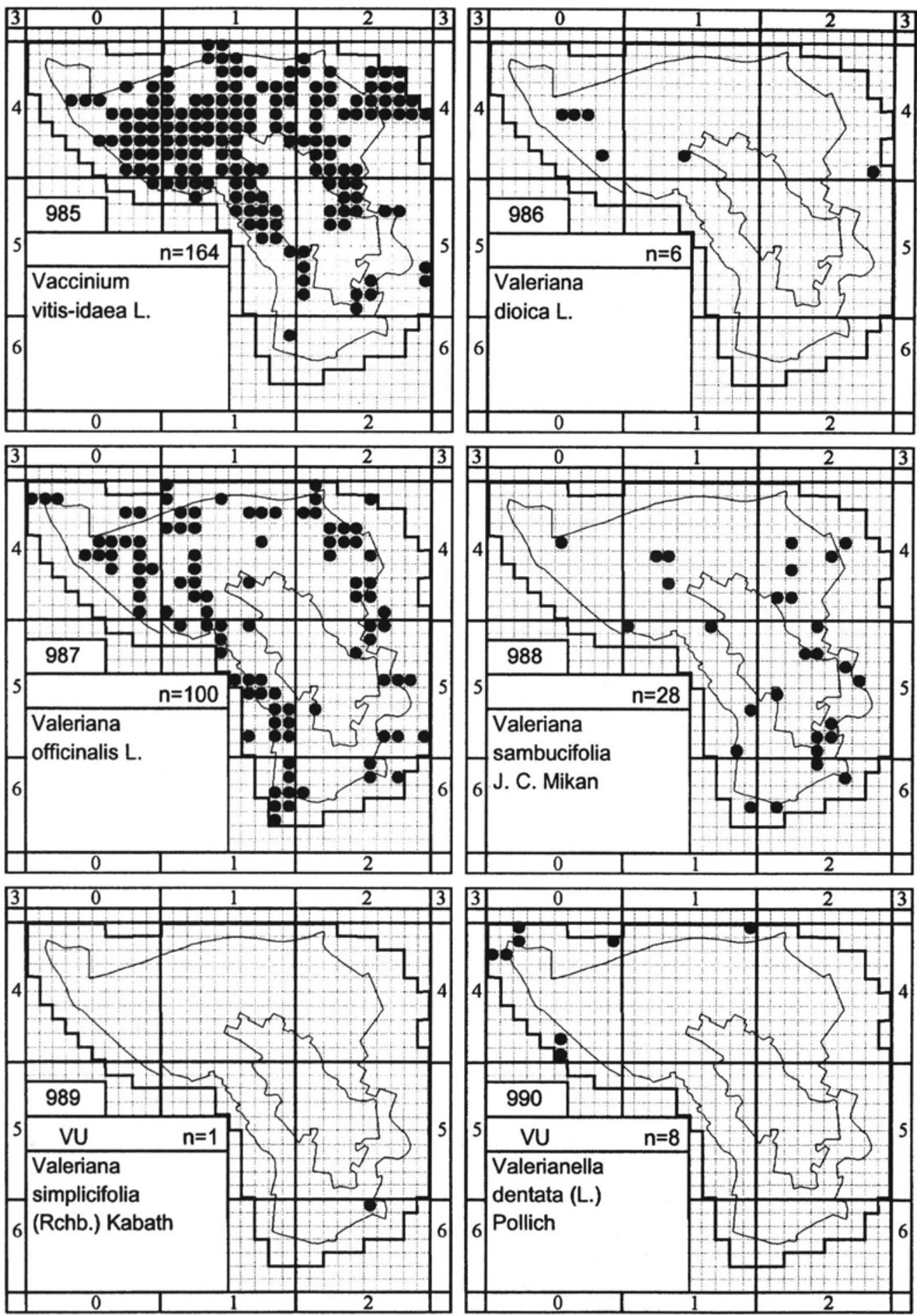



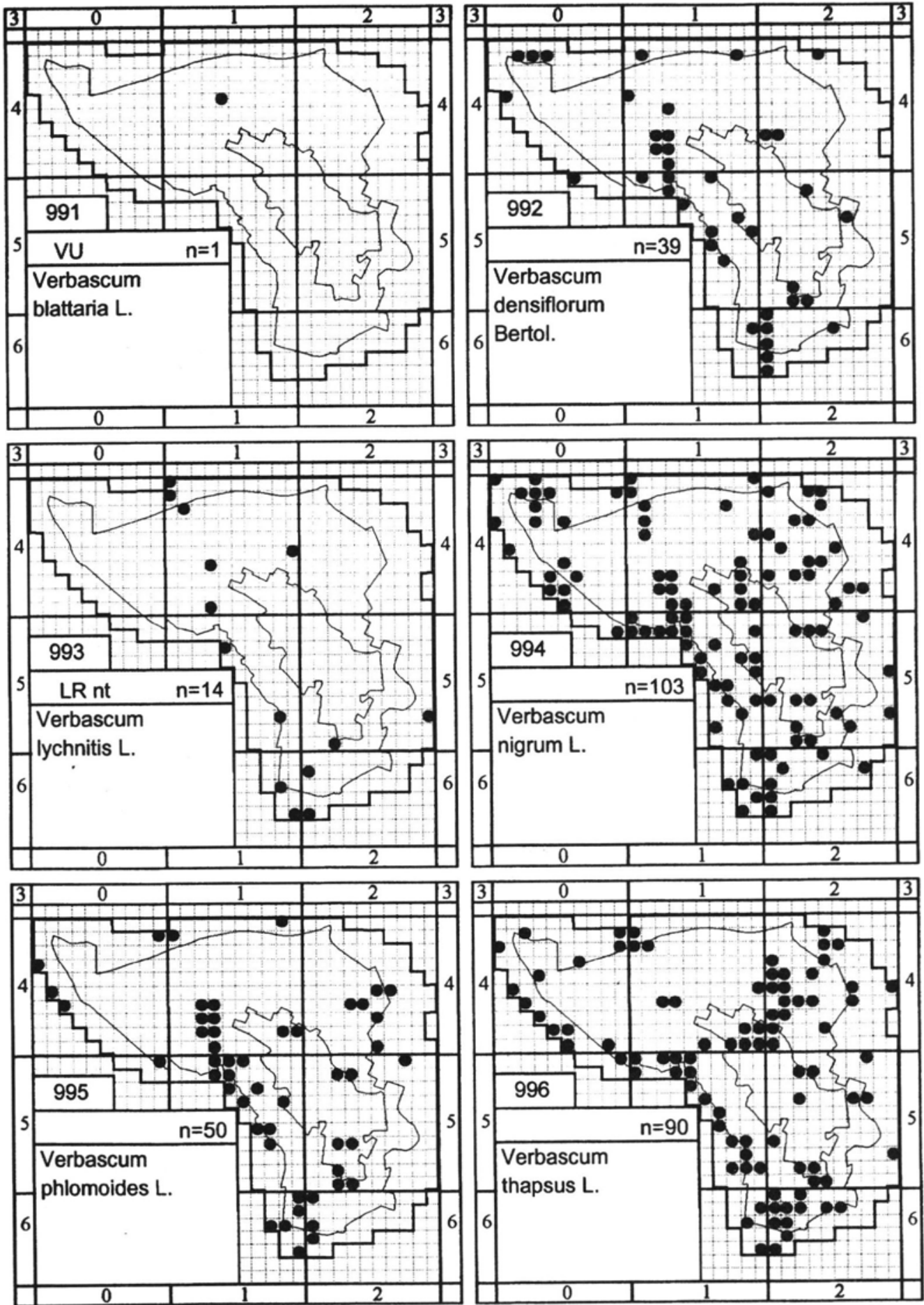

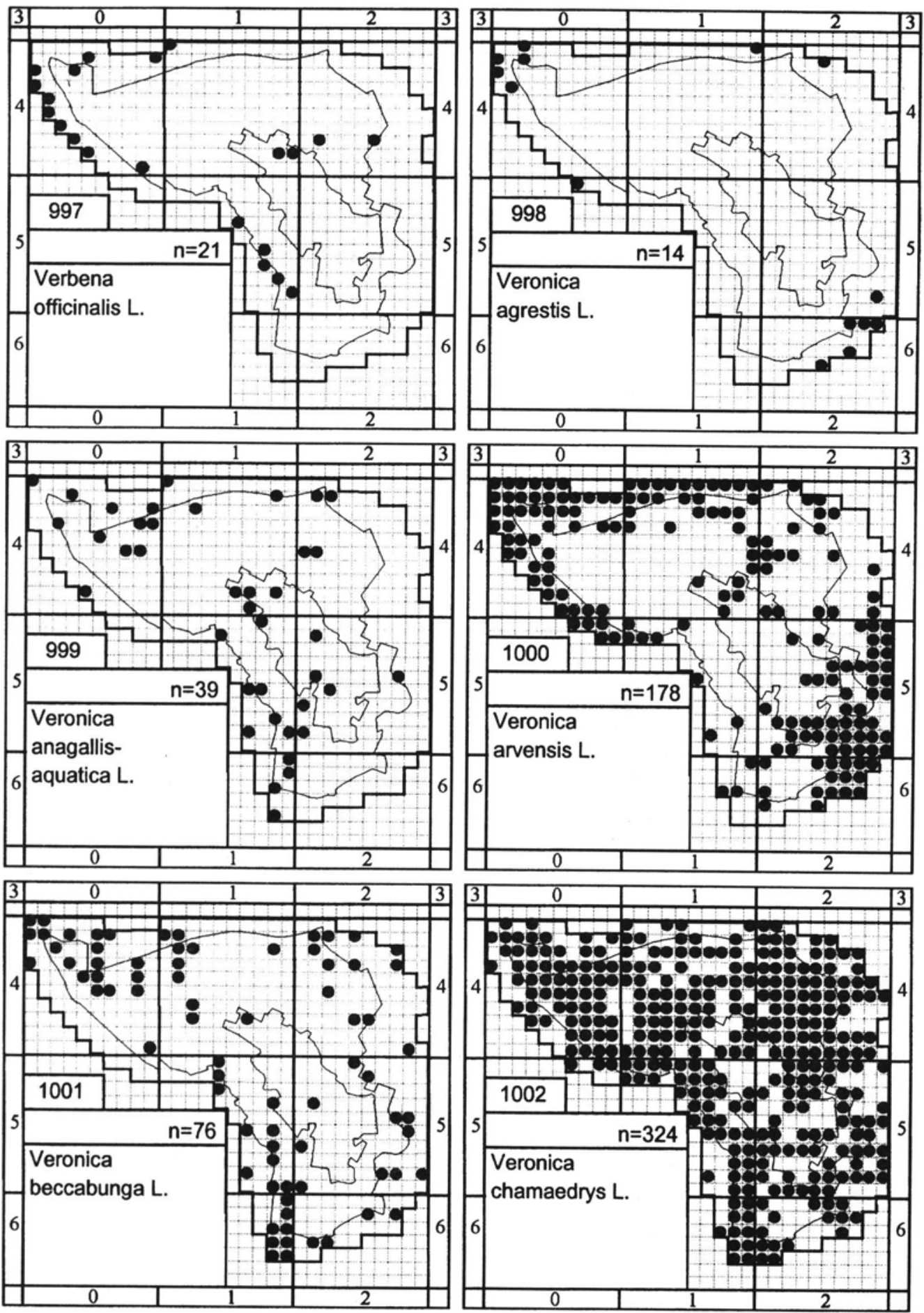

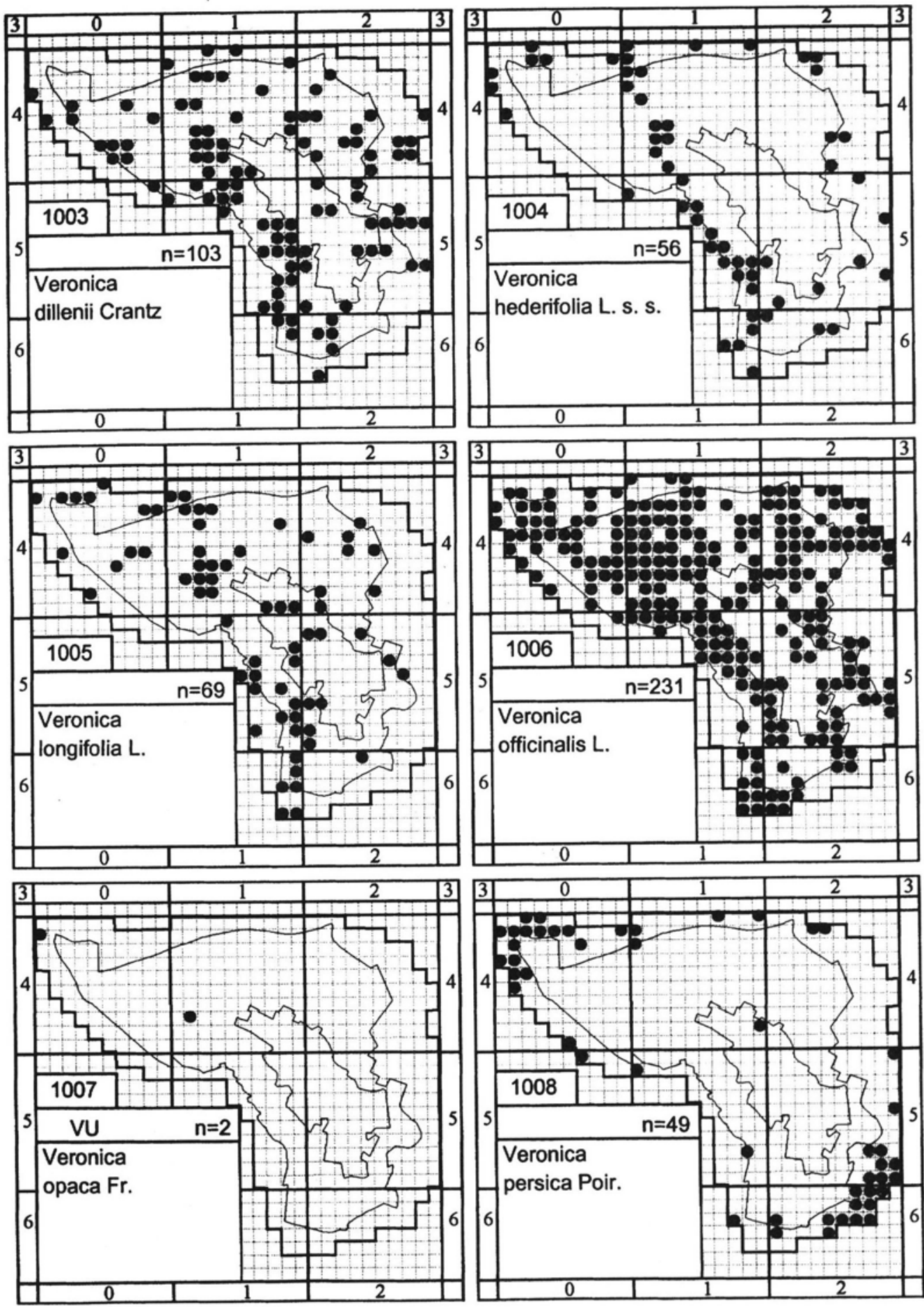


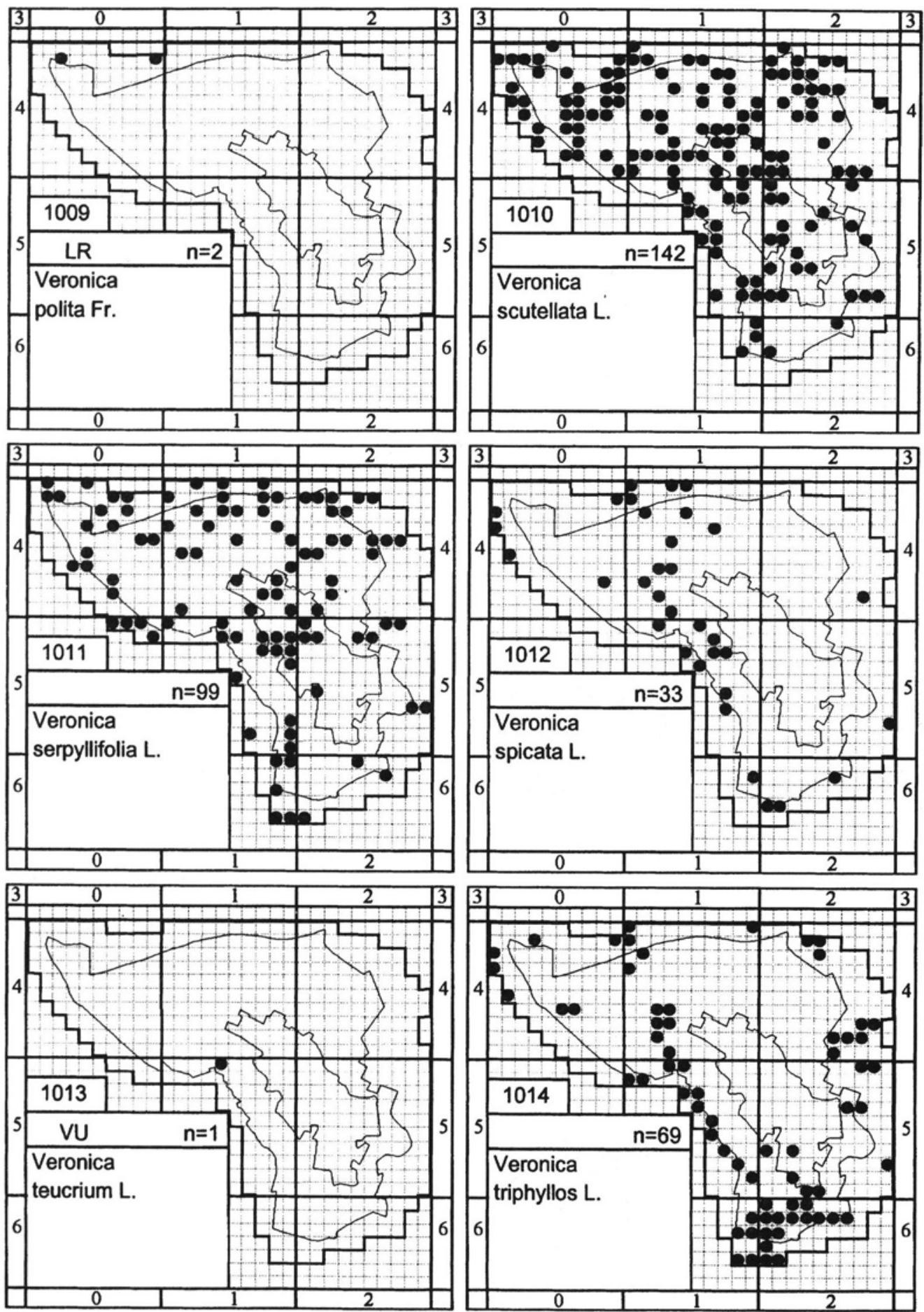



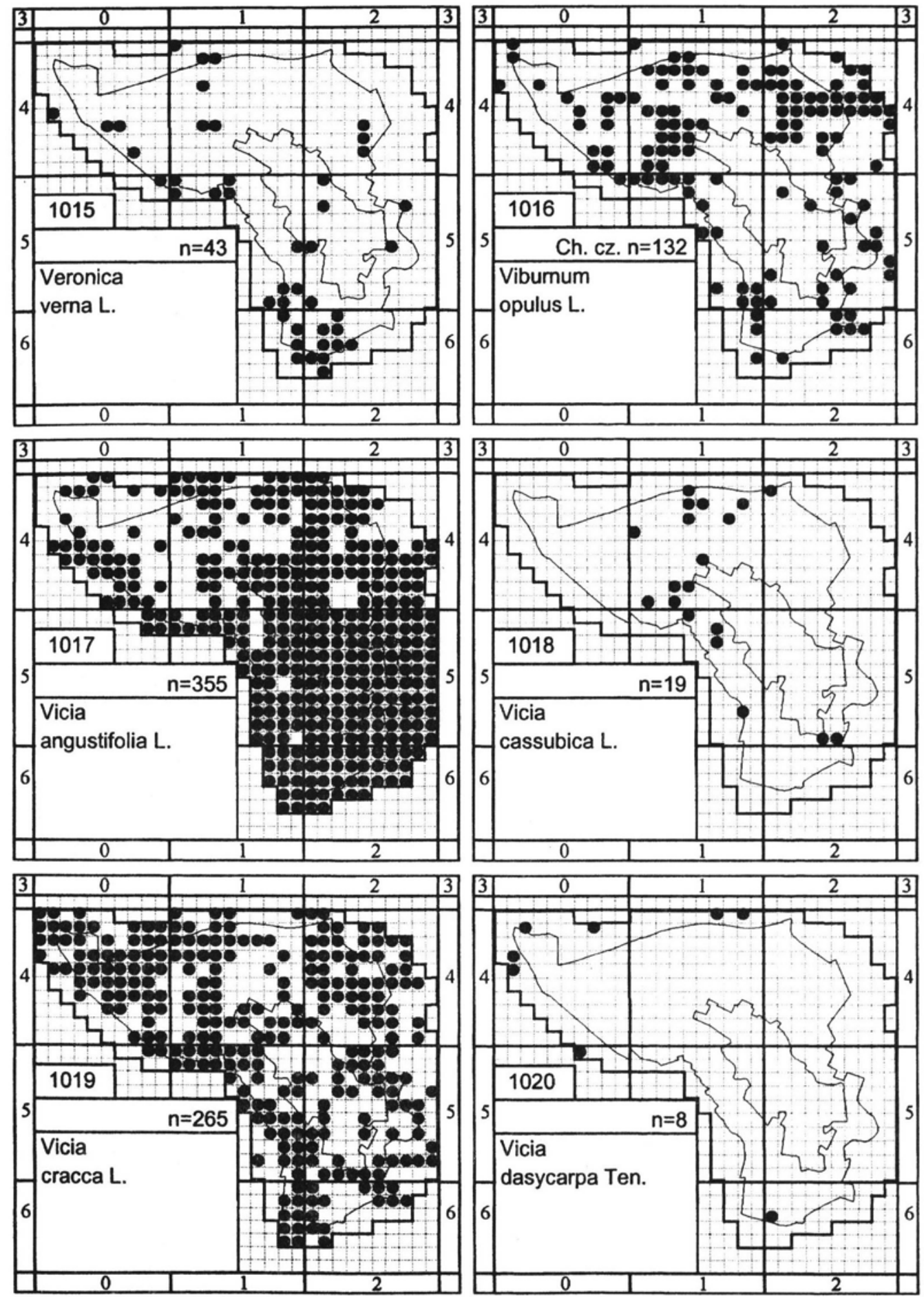


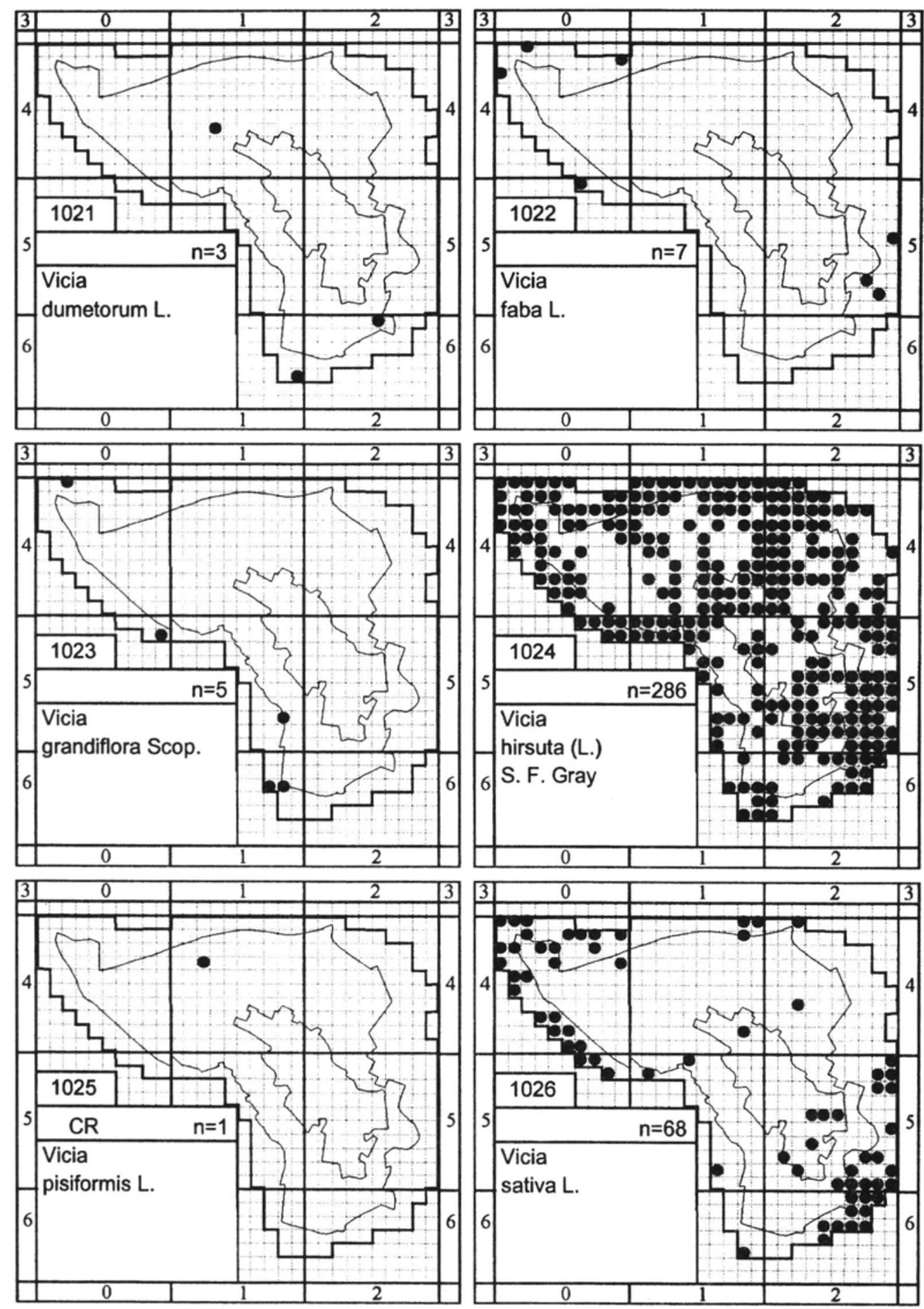




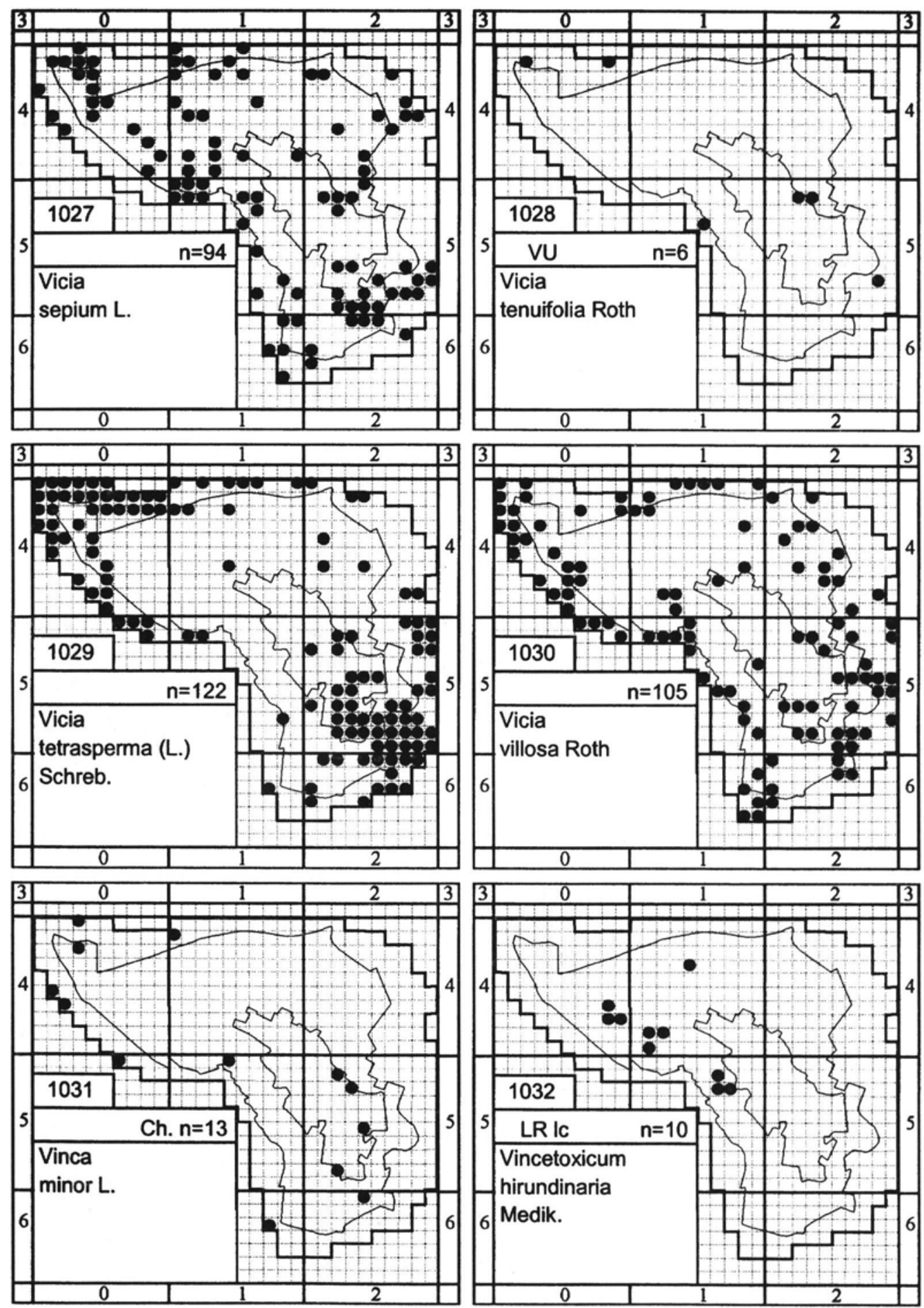



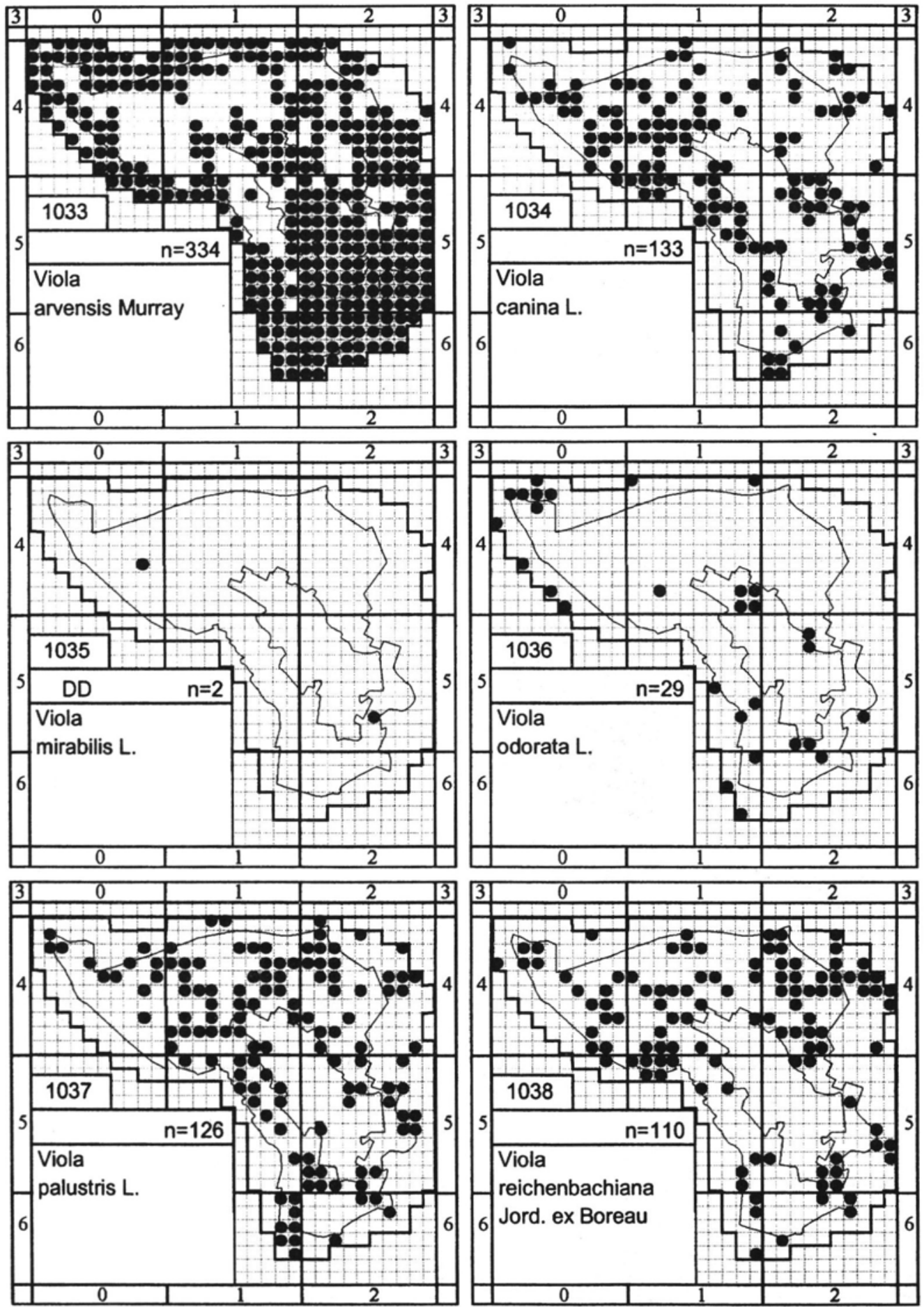

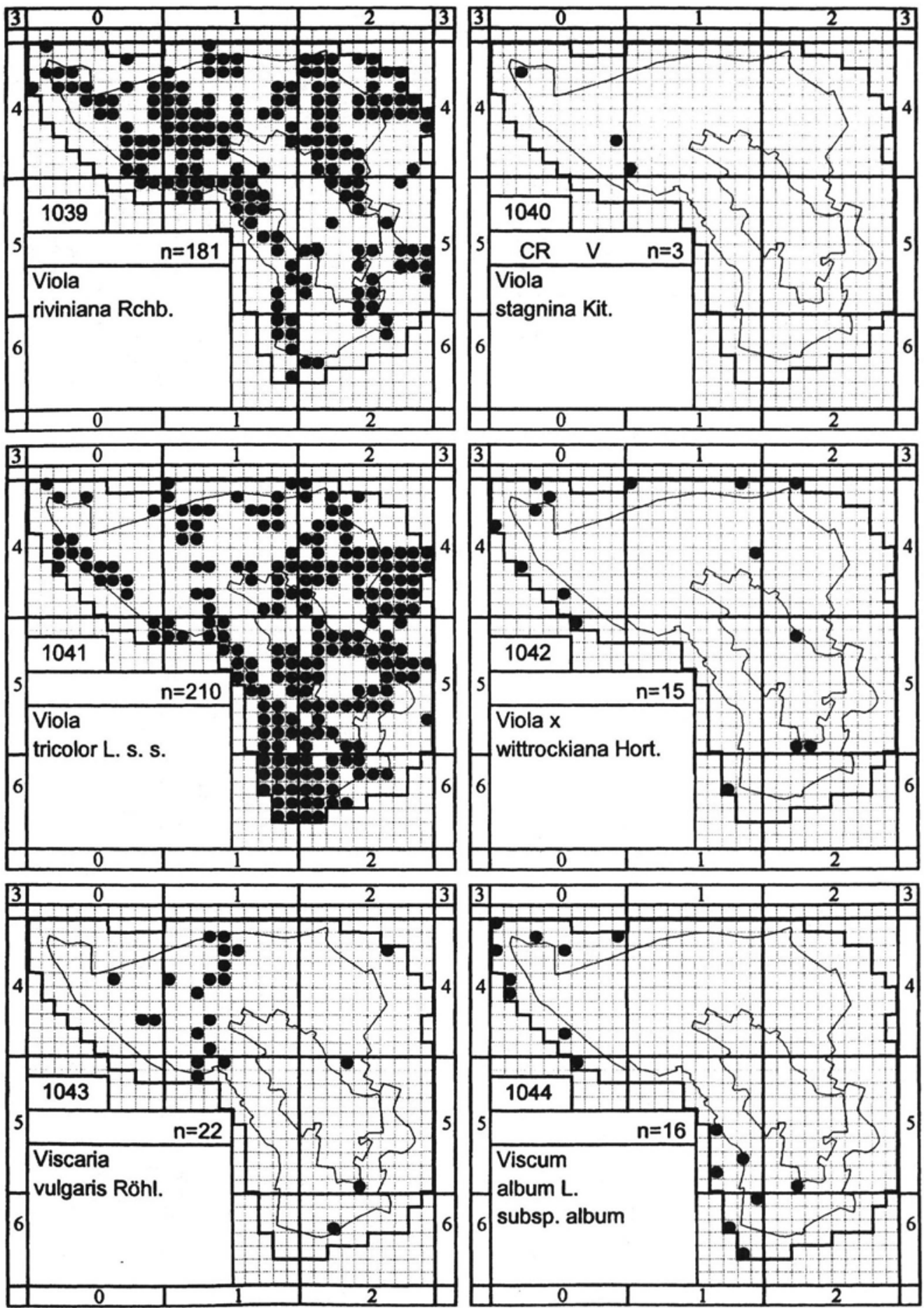

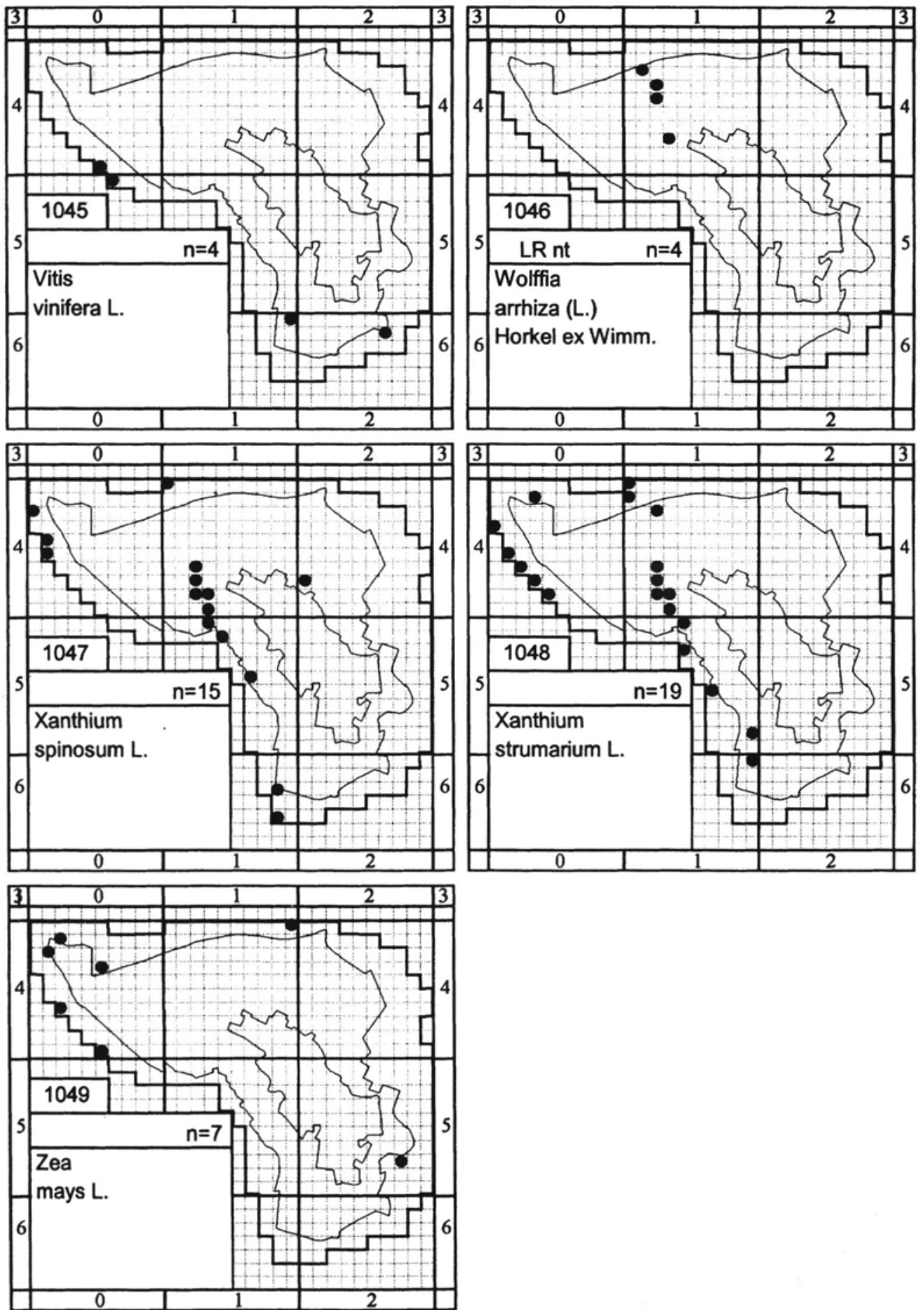